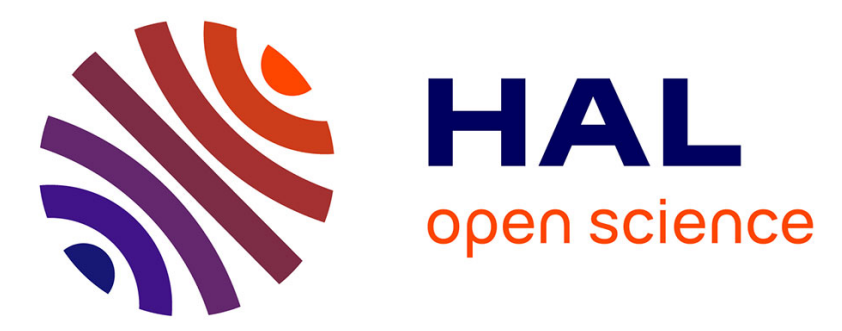

\title{
Garnet as a monitor for melt-rock interaction: Textural, mineralogical, and compositional evidence of partial melting and melt-driven metasomatism
}

Philippe Goncalves, Tom Raimondo, Jean-Louis Paquette, Jailma Santos de Souza de Oliveira

\section{To cite this version:}

Philippe Goncalves, Tom Raimondo, Jean-Louis Paquette, Jailma Santos de Souza de Oliveira. Garnet as a monitor for melt-rock interaction: Textural, mineralogical, and compositional evidence of partial melting and melt-driven metasomatism. Journal of Metamorphic Geology, 2021, 39 (5), pp.617-648. 10.1111/jmg.12592 . hal-03267507

\section{HAL Id: hal-03267507 \\ https://hal.uca.fr/hal-03267507}

Submitted on 22 Nov 2021

HAL is a multi-disciplinary open access archive for the deposit and dissemination of scientific research documents, whether they are published or not. The documents may come from teaching and research institutions in France or abroad, or from public or private research centers.
L'archive ouverte pluridisciplinaire HAL, est destinée au dépôt et à la diffusion de documents scientifiques de niveau recherche, publiés ou non, émanant des établissements d'enseignement et de recherche français ou étrangers, des laboratoires publics ou privés.

\section{(ㄷ)(1) $\$$}

Distributed under a Creative Commons Attribution - NonCommerciall 4.0 International 


\section{Garnet as a monitor for melt-rock interaction: textural, mineralogical and compositional evidence of partial melting and melt-driven metasomatism}

\begin{tabular}{|r|l|}
\hline Journal: & Journal of Metamorphic Geology \\
\hline Manuscript ID & JMG-20-0059.R1 \\
\hline Manuscript Type: & Original Article \\
\hline Author: & n/a \\
\hline Complete List of Authors: & $\begin{array}{l}\text { Goncalves, Philippe; Université de Bourgogne Franche-Comté, } \\
\text { Laboratoire Chrono-environnement / CNRS } \\
\text { Raimondo, Tom; University of South Australia, UniSA STEM; University } \\
\text { of South Australia, Future Industries Institute } \\
\text { Paquette, Jean Louis; Université Clermont Auvergne, Laboratoire } \\
\text { Magmas et Volcans } \\
\text { Santos de Souza, Jailma; Universidade Federal da Bahia, Instituto de } \\
\text { Geociências. }\end{array}$ \\
\hline Keywords: & $\begin{array}{l}\text { garnet zoning, partial melting, chemical potential, diffusion } \\
\text { metasomatism, LA-ICP-MS mapping }\end{array}$ \\
\hline
\end{tabular}

\section{SCHOLARONE \\ Manuscripts}


3 Garnet as a monitor for melt-rock interaction: textural, mineralogical and compositional

4 evidence of partial melting and melt-driven metasomatism

5

6 Abridged title : Garnet as a monitor for melt-rock interaction

7

8 Philippe Goncalves $^{1 *}$, Tom Raimondo ${ }^{2,3}$, Jean-Louis Paquette ${ }^{4}$, Jailma Santos de Souza ${ }^{5}$

11 1: Laboratoire Chrono-Environnement, CNRS / Université de Bourgogne-Franche-Comté, 16 route 12 de Gray, 25030 Besançon, France

132 : UniSA STEM, University of South Australia, GPO Box 2471, Adelaide SA 5001, Australia

143 : Future Industries Institute, University of South Australia, GPO Box 2471, Adelaide SA 5001,

15 Australia

164 : Laboratoire Magmas et Volcans, Université Clermont-Auvergne, CNRS, IRD, OPGC, 63000

17 Clermont-Ferrand, France

5 : Centro de Pesquisa em Geofisica e Geologia, Universidade Federal da Bahia, Rua Caetano Moura 123, Federaçao Cep 40210-340 Salvador, Bahia, Brazil

23 * corresponding author: philippe.goncalves@univ-fcomte.fr 


\section{ABSTRACT}

In this study, we focus on a partially melted garnet-bearing granulite from the Salvador-

Esplanade belt (Salvador da Bahia, Brazil), and examine the behavior of major and trace elements during partial melting and melt-driven metasomatism. Phase equilibria modeling and $\mathrm{U}-\mathrm{Th}-\mathrm{Pb}$ geochronology shows that the sample underwent partial melting during the heating segment of the decompression path from $\sim 1.2 \mathrm{GPa}$ and $675-700^{\circ} \mathrm{C}$ to $\sim 0.8 \mathrm{GPa}$ and $790^{\circ} \mathrm{C}$ at $\mathrm{ca}$.

2.06 Ga. During the last stage of decompression, from 0.8 to $\sim 0.5 \mathrm{GPa}$, physical segregation of melt resulted in the establishment of chemical potential gradients and mass transfer between the host-granulite and the leucosome. Modelling shows that $\mathrm{H}_{2} \mathrm{O}, \mathrm{CaO}, \mathrm{K}_{2} \mathrm{O}$ and $\mathrm{Na}_{2} \mathrm{O}$ diffuse from the melt into the host residue, whereas $\mathrm{SiO}_{2}$ is transferred from the host-granulite into the adjacent leucosome. Opposed senses of diffusional transfer resulted in the formation of a quartz-rich anhydrous leucosome and a quartz-undersaturated selvage in the host-granulite. Compositional maps show that garnets exhibit unusual and contrasting major and trace element distribution depending on their textural position. The largest garnets located in the quartzundersaturated selvage preserve their original $\mathrm{Ca}$ and trace element growth zoning. A transition from bell-shaped profiles for $Y$ and HREEs to bowl-shape profiles for LREEs is consistent with a typical Rayleigh fractionation model, fast intergranular element mobility and rock-wide equilibrium during prograde partial melting. In contrast, smaller garnets away from the leucosome show evidence of prograde growth zoning modified by intragranular diffusion, as evidenced by a network of open channels and healed-cracks that act as connecting pathways between the matrix and garnet core. This results in either subtle modification of both major and trace elements adjacent to the inner core inclusions, or a complete re-equilibration. The recognition that the initial Ca growth zoning, including the inner core compositions, was later modified by intragranular diffusion implies that misleading thermobarometric results and tectonic interpretations would be obtained if the garnet core composition was used to fingerprint the early garnet nucleation stage. This study further demonstrates that at high 
55 temperature $\left(>750^{\circ} \mathrm{C}\right)$ and in the presence of melt, REE are not less vulnerable to diffusive 56 resetting than divalent cations like $\mathrm{Ca}^{2+}$.

57 keywords : garnet zoning, partial melting, chemical potential, diffusion metasomatism, LA-ICP58 MS

59 


\section{INTRODUCTION}

Partial melting is a fundamental process for differentiating (Brown, 2010) and weakening the deep crust (Piazolo, Daczko, Silva \& Raimondo, 2020; Rosenberg \& Handy, 2005), which in turn exerts a first-order control on deformation style, lateral redistribution of mass, crustal thickness and surface topography (Beaumont, Jamieson, Nguyen \& Medvedev, 2004; Hollister \& Crawford, 1986; Jamieson, Unsworth, Harris, Rosenberg \& Schulmann, 2011; Rabin, Trap, Carry, Fréville \& Cenki-Tok, 2015; Royden et al., 1997; Vanderhaeghe, 2012). Exhumed migmatites preserve, through their mineralogy and structure, a wealth of information that can be used to decipher the thermo-mechanical behavior of orogenic continental crust. With this motivation, the petrological analysis of partially melted feldsic rocks is now commonplace in metamorphic petrology, thanks to extended experimental work (e.g. Clemens, 1984; Grant, 1985; Le Breton, 1988; Thompson, 1982; Vielzeuf \& Holloway, 1988; Vielzeuf \& Montel, 1994) and thermodynamic phase relation modeling (Holland \& Powell, 2001a; Spear, Kohn \& Cheney, 1999; Vielzeuf \& Schmidt, 2001; White, Powell \& Holland, 2001; White \& Powell, 2010). Despite this progress, modeling phase relations in migmatites is not trivial because they are subject to redistribution and transfer of the highly mobile melt component at various scales, from grain- to crustal-scale (Etheridge, Daczko, Chapman \& Stuart, 2020; Sawyer, 2001). Therefore, phase relation modeling in migmatites requires the consideration of not only changes in environmental variables like pressure and temperature, but also the variation of the equilibrium volume and composition of the system (i.e. open system processes).

Modeling the role of melt transfer (loss and gain) on phase relations has been extensively investigated (Alessio, Hand, Morrissey, Kelsey \& Payne, 2017; Bartoli, 2017; Dumond, Goncalves, Williams \& Jercinovic, 2015; White et al., 2001; Yakymchuk \& Brown, 2014; ). Among the many benefits of open system forward modeling is the application of a melt-reintegration approach that consist of recovering the bulk composition prior to any melt transfer. This method allows investigating the prograde evolution of melt-bearing systems that tend to be obliterated by continuous re-equilibration up to peak metamorphic conditions. Another complexity arising from 
the segregation of melt from the solid residue is that the system becomes physically and chemically differentiated into melt-rich domains (leucosome) and solid-rich domains (melanosome). The thermodynamic system is therefore composed of two sub-systems that will interact, with changing pressure and temperature conditions, due to the establishment of chemical potential gradients of components at the interface between both sub-systems (White \& Powell, 2010). The diffusion of components $\left(\mathrm{H}_{2} \mathrm{O}, \mathrm{SiO}_{2}, \ldots\right)$ between the two sub-systems produces significant variations in composition, mineral reactions and assemblages (Fitzsimons, 1996; White \& Powell, 2010). Despite this conceptual framework being generally accepted, meltrock interaction in segregated migmatites remains rarely identified via textural, geochemical and/or mineralogical evidence, nor investigated via thermodynamic modeling (Kriegsman \& Hensen, 1998; Lin \& Sawyer, 2019; White \& Powell, 2010). In migmatites, garnet is very common as a peritectic phase and has the ability to preserve zoning of divalent cations ( $\mathrm{Fe}, \mathrm{Mg}, \mathrm{Ca}$ and $\mathrm{Mn}$ ) that reflects changing $\mathrm{P}-\mathrm{T}$ conditions and/or bulk rock chemistry, either due to garnet fractionation or mass transfer during melt segregation, transport and interaction with the garnet-bearing residual rock (e.g. Caddick, Konopásek \& Thompson, 2010; Konrad-Schmolke, O’Brien, de Capitani \& Carswell, 2008). To retrieve the maximum information related to garnet chemical evolution, the characterization of major element zoning can be complemented with trace elements (Hyppolito et al., 2019; Raimondo et al., 2017). Trivalent cations, like rare-earth elements, have lower diffusion coefficients than major divalent cations. They are therefore more resistant to diffusional modification and allow the preservation of prograde and high temperature processes (Carlson, 2012; Gaidies et al., 2020; George \& Gaidies, 2017; Moore, Carlson \& Hesse, 2013; Rubatto et al., 2020 ), including those involved during partial meting (Dumond et al., 2015).

The trace element characteristics of garnet can be linked to the evolution of accessory phases used for geochronology (e.g. monazite, zircon and rutile) to better constrain tectonometamorphic histories (Dumond et al., 2015; Hermann \& Rubatto, 2003; Mahan, Goncalves, Williams \& Jercinovic, 2006; Prent et al., 2019; Pyle \& Spear, 2003; Tomkins \& Pattison, 2007; Weller, jackson, Miller, St-Onge \& Rayner, 2020). They also provide insight into 
the mechanisms controlling the uptake (interface- vs diffusion-controlled growth) and mobility of trace element during metamorphism and metasomatism (George, Gaidies \& Boucher, 2018; Konrad-Schmolke, Zack, O’Brien \& Jacob, 2008; Moore et al., 2013; Raimondo et al., 2017; Skora et al., 2006). With the recent development of in-situ laser ablation - inductively coupled plasma - mass spectrometry (LA-ICP-MS), it is now possible to rapidly and quantitatively map the 2D distribution of trace elements across major and accessory minerals of interest (George et al., 2018; Raimondo et al., 2017; Ubide, McKenna, Chew \& Kamber, 2015). Yet, despite the known benefits of analyzing trace elements in garnet for the purposes listed above, there remains a limited number of studies using this approach to understand the grain-scale controls on garnet crystallization (Gaidies et al. 2020; George et al., 2018; Rubatto et al. 2020). In this contribution, we report the integrated petrological and geochemical characterization of a high-grade rock that preserves evidence of changes in P-T conditions, partial melting and melt-driven metasomatism. The selected sample, from the São Francisco craton in Brazil, is a layered composite rock that consists of a garnet-bearing quartz-saturated host granulite, a quartzo-feldspatic leucosome, that may correspond to crystallized segregated melt or differentiated melt residue (Guernina \& Sawyer, 2003), and a quartz-undersaturated garnet-bearing selvage formed at the interface between the host-granulite and leucosome. Petrological analysis and thermodynamic modeling (using P-T- $\mu-\mathrm{X}$ phase diagrams, where $\mu=$ chemical potential and $\mathrm{X}=$ composition) shows that the distinct mineralogy of the selvage is the result of mass transfer driven by chemical potential gradients established between the hostgranulite and the segregated melt during decompression. In addition, garnets show a consistent change in grain size, morphology, major and trace element composition and zoning patterns across the gneissic layering, as revealed by quantified LA-ICP-MS raster maps. The strong correlation between textural position and zoning pattern in garnet gives insight into the grainscale petrogenetic processes involved in partially-molten granulites. We distinguish the role of (1) intergranular mobility of elements and accessory phases during metamorphic garnet growth; and (2) post-growth intragranular diffusion of major and trace elements during melt-driven metasomatism. 


\section{GEOLOGICAL SETTING}

\subsection{São Francisco craton and the Salvador-Esplanade belt}

The São Francisco Craton, located in the east-central part of Brazil, consists of an Archean to Paleoproterozoic crystalline basement mostly overlain by Meso to Neoproterozoic sediments in its western part (Figure S1). The craton is bounded by Neoproterozoic marginal fold belts (Figure S1). The eastern part of the craton, where most of the metamorphic rocks are exposed, is subdivided into four major geological units: three Archean blocks (Gavião, Jequié and Serrinha) and two Paleoproterozoic belts: the Itabuna-Salvador-Curaçá Orogen (ISCO) and the SalvadorEsplanada belt (SEB) (Figure S1) (Barbosa \& Sabaté, 2004, see references therein). The southernmost part of the Salvador-Esplanada belt, where this study has been conducted, trends broadly North-East and consists mostly of mafic to felsic granulites and migmatites.

\subsection{Farol da Barra: metamorphism and age constraints}

In the Salvador da Bahia city, high grade metamorphic and magmatic rocks of the SEB are exposed in a horst that is bound on the western side by the Recôncavo sedimentary basin and on the eastern side by the Atlantic coastal margin. The studied area is located at the Barra lighthouse (Farol da Barra; $13^{\circ} 00^{\prime} 41^{\prime \prime S}$; 38 31’57'W, Figure 1a). Four distinct lithologies are identified (Souza Barbosa \& Gomes, 2010; Souza-Oliveira et al., 2014) (Figure 1a): (1) orthopyroxenebearing granulites that constitute most of the basement of the city of Salvador da Bahia and are interpreted to be derived from late Archean tonalitic magmatic rocks (2) garnet-bearing granulites and sapphirine-bearing Al-Mg granulites interpreted as meta-sediments (3) granulitized ultramafic and mafic rocks that occur as centimeter to meter-scale boudins within the paraderived granulites; and (4) monzonitic to syenitic intrusives dykes, oriented $\sim \mathrm{N} 10^{\circ}$ (Figure 1a), that are either deformed or undeformed with sharp intrusive contacts. Metamorphic conditions have been estimated at $0.75-0.9 \mathrm{GPa}$ and $840-900^{\circ} \mathrm{C}$ in the sapphirine-bearing granulites (Fujimori, 1988). The age of the granulitic metamorphism has been 
constrained by SHRIMP U-Pb dating at $2089 \pm 11 \mathrm{Ma}$ on zircon overgrowths from the orthopyroxene-bearing granulites (Da Silva, McNaughton, 1997). On the same samples, zircon cores yielded an age of $2561 \pm 7 \mathrm{Ma}$ interpreted as the crystallization age of the protolith magmatic rocks. The later syenitic to monzonitic magmatism has been dated by $\mathrm{Pb}-\mathrm{Pb}$ evaporation on zircon at $2064 \pm 6$ Ma (Souza et al., 2010).

\subsection{Farol da Barra: structural relationships}

The Barra lighthouse outcrop is characterized by a complex ductile finite strain pattern that results from the superposition of two main phases of deformation $\left(D_{1}\right.$ and $\left.D_{2}\right)$ (Figure $\left.1 b\right)$. The overall geometry consists of meter to decameter lenses, in which $D_{1}$ structures are best preserved, surrounded by $D_{2} \sim$ East-West striking high strain zones (Figures $1 \mathrm{~b}$ and S2). The first deformation phase $\left(D_{1}\right)$ is characterized by a gently dipping gneissic foliation $\left(S_{1}\right)$ that strikes NESW (Figure $1 \mathrm{~b}$ and S2). This foliation is associated with isoclinal folds with axial planes parallel to $S_{1}$ (Figure $1 b$ ). The $S_{1}$ foliation bears a sub-horizontal $L_{1}$ stretching and mineral lineation plunging $0-20^{\circ}$, marked by the preferred orientation of feldspars, quartz ribbons, mafic mineral and elongated ultramafic to mafic boudins. The second deformation phase $\left(D_{2}\right)$ is characterized by heterogeneous deformation that progressively steepens and transposes the previous $D_{1}$ fabric along upright $D_{2}$ folds and steeply dipping high strain zones $\left(>55^{\circ}\right)$ that forms an anastomosing network of conjugated shear zones trending approximately east-west (Figures $1 \mathrm{~b}$ and S2). An $L_{2}$ lineation is defined by stretched quartz, feldspars and by the preferred orientation of biotite with a moderate plunge of 10 to $35^{\circ}$ towards the NE.

Kinematic analysis in the low $D_{2}$ strain domains show that the two sets of ductile conjugate shear zones consist of a dominant 108/72SSW dextral shear zone and minor sinistral 021/79ESE shear zones (Figure S2). This pattern of $D_{2}$ finite strain is consistent with a NNW-SSE shortening and a bulk dextral sense of shear. The NW-SE cross-section from the Santa Maria Forte towards the Cristo hill (Figure 1b) shows that the studied area (the Barra lighthouse) corresponds to a major localized $D_{2}$ high strain zone within a preserved $D_{1}$ low strain domain characterized by gently dipping foliation. Whereas the $D_{1}$ domains (Santa Maria fort, Hispaniola hospital, and 
Cristo Hill) consist mainly of orthopyroxene-bearing granulites, the Barra lighthouse $D_{2}$ high strain zone is characterized by the abundance of garnet-bearing granulite. This apparent relationship between deformation and lithology is beyond the scope of this contribution and will not be

discussed further.

\section{TEXTURAL AND MINERALOGICAL CHARACTERISATION}

\subsection{Outcrop and sample descriptions}

The studied sample is located in a $S_{2}$ high strain zone that surrounds a large decametric lense of low strain rocks where an earlier fabric $\left(S_{1}\right)$ is preserved (Figure 1). The $S_{2}$ granulitegrade gneissic foliation is steeply dipping (072/80S) and contains a gently plunging mineral lineation $(09->075)$ defined by the preferred orientation of biotite and sillimanite. The gneissic foliation is marked by a compositional banding with centimer-wide quartzo-feldspathic leucosomes in a garnet-bearing granulite (Figure 2a). Leucosomes are usually less than a three centimeters in width and are systematically surrounded by a centimeter thick dark and coarsegrained quartz-undersaturated selvage developed at the expense of the surrounding garnetbearing granulite (Figure $2 b$ ).

The studied sample 06SB06 encompasses the three lithologies described above: the host quartz-saturated granulite, a $1 \mathrm{~cm}$-wide quartz-undersaturated selvage and a thin leucosome (Figure $2 \mathrm{~b}$ ). The peak-metamorphic assemblage of the quartz-saturated granulite consists of garnet, sillimanite, plagioclase, biotite, quartz and K-feldspar (Figure 3a). Garnet is interpreted as a peritectic phase produced during biotite dehydration melting via the reaction:

$$
\text { biotite }+ \text { sillimanite }+ \text { plagioclase }+ \text { quartz } \pm \text { K-feldspar }=\text { garnet }+ \text { melt }
$$

Spinel is locally observed in the matrix but it is always surrounded by a thin corona of sillimanite and it is never in contact with quartz. The preferred orientation of large sillimanite blades (up to $5 \mathrm{~mm}$ ), K-feldspar and biotite, that occurs either as small flakes or large resorbed grains, 
defines the main $\mathrm{S}_{2}$ foliation observed at the outcrop scale. Garnet contains numerous quartz inclusions and polyphase aggregates of plagioclase + quartz with minor biotite inclusions that all show a preferred orientation at high angle with respect to the $S_{2}$ foliation (Figure 3a). This alignment is interpreted as a relict of the former shallow dipping $S_{1}$ foliation. Peak metamorphic garnet in contact with sillimanite is partially resorbed and surrounded by a moat of retrograde cordierite (Figure $3 \mathrm{~b}$ ), consistent with the classic reaction

$$
\text { garnet }+ \text { sillimanite }+ \text { quartz }=\text { cordierite } \pm \text { melt } \pm \text { ilm }
$$

which proceeds during decompression and/or cooling.

The selvage, in direct contact with the leucosome, is composed of the same peak metamorphic assemblage, consisting of prismatic sillimanite, plagioclase, garnet, biotite and Kfeldspar, except it lacks quartz. Biotite is more abundant than in the quartz-saturated granulite. Garnet cores contain numerous quartz inclusions, in association with plagioclase, suggesting that the onset of partial melting and crystallization of peritectic garnet occurred under quartzsaturated conditions. Garnet porphyroclasts are partially broken-down into cordierite and sillimanite is strongly resorbed and replaced by cordierite + spinel symplectites (Figure 3c) via the reaction

$$
\text { sillimanite }+ \text { garnet } \pm \text { melt } \pm \text { biotite }=\text { spinel }+ \text { cordierite }
$$

The leucosome consists mainly of quartz and thin elongated K-feldspar ribbons.

Plagioclase is very rare and occurs as late myrmekite intergrowths next to K-feldspar. Mineral compositions are available in Dataset S1. Biotite has XMg of 0.67-0.69 and 0.710.73 for the small flakes and large grains respectively, with a constant Ti content of 0.25 to 0.30 pfu. Plagioclase in the matrix has a variable range in anorthite content from 0.43 to 0.52 . Spinel is very homogeneous in composition with a XMg of 0.31 . Garnet compositions are described in Section 4.

\subsection{Evolution of garnet morphology and inclusions}

One of the most conspicuous observations is the evolution of garnet size, distribution of 
inclusions and composition across the quartz-undersaturated selvage and the granulite perpendicular to the gneissic layering. Although no quantitative textural analysis has been conducted, it appears that garnet grain size decreases and the number of garnet grains increases away from the leucosome, with the biggest garnet grains observed in the quartz-undersaturated selvage (Figures 4 and 5). Furthermore, the amount, shape and composition of inclusions in garnet varies greatly and continuously across the gneissic foliation. To describe this evolution, seven garnets (A to $G$ ) were selected (see location in Figure 4).

In the quartz-undersaturated selvage, most garnets contain a few rounded inclusions of quartz in their core (garnet A, Figure 5a). Away from the leucosome, but still in the selvage, the largest garnet porphyroblast (b) contains in its core a small polymineralic inclusion, that consists of plagioclase and quartz, surrounded by rounded isolated quartz inclusions (Figure 5b). Inclusion-rich garnet cores are surrounded by a large rim free of inclusions except for numerous and homogeneously distributed crystallized granitic melt inclusions that are less than 20 microns in diameter (Figures 5a-b and 6). The inclusions have been identified as crystallized melt based on the main microstructural criteria summarized in Cesare, Acosta-Vigil, Bartoli \& Ferrero (2015) : (1) the development of a perfect negative crystal shape (Figure 6a); (2) its polycrystalline nature that consists of biotite, plagioclase, quartz and apatite for the most common phases (nanogranitoids) (Figure 6b-c); and (3) the development of cracks (decrepitation) during decompression filled with minerals similar to those in the melt inclusion(Figure S6). The presence of these crystallized melt inclusions attest to the growth of the garnet rim in the presence of melt.

In the quartz-saturated granulite, the abundance of polymineralic inclusions of plagioclase and quartz observed in garnets increases away from the leucosome (Figures 4 and 5cg). The garnet core, defined as the garnet containing plagioclase-quartz polymineralic inclusions surrounded by isolated quartz grains can be as large as $1 \mathrm{~mm}$ and represent up to $50 \%$ of the garnet volume. Polymineralic inclusions have rounded (Figure $5 c-d-f)$ to very irregular shapes with straight boundaries (Figure 5e). These facets are inferred to be parallel to crystallographic orientations of the garnet host and result from post-entrapment readjustment of the inclusion 
and host by dissolution-reprecipitation processes (e.g. Frezotti, 2001). Plagioclase in the polymineralic inclusions are chemically zoned with a composition varying almost continuously from pure anorthite $A n_{95} A b_{05}$ to $A n_{58} A b_{41}$. Highest amounts of albite are measured in the vicinity of rounded quartz inclusions within plagioclase and the garnet host (Figure S3). All garnets have an inclusion-free rim without any melt-inclusions, as for the garnet located in the quartzundersaturated selvage (Figure 5). This difference in the ability for garnet rims to entrap melt inclusions may be related to a slowdown of radial growth rate as garnet continuously grows. X-ray computed microtomography and sequential cuts through a single garnet crystal has been performed to highlight the volume, shape and potential connectivity of the polyphased inclusions with the matrix. The selected garnet is located in the quartz-saturated granulite where the amount of polyphase quartz-plagioclase is most abundant. The X-ray tomography reveals the very irregular shape of the polyphased inclusions as well as the "spongy" texture of the garnet core (Figure 7). Although all thin-section photomicrographs of garnet presented in Figure 5 suggest that polyphase inclusions are completely enclosed in the garnet, the 2D cuts rather suggest that they are connected to the matrix through small pathways (Figure $7 d-f$ and Movie S1).

\subsection{Microtextures in the quartz-undersaturated selvage}

Microtextures in the quartz-undersaturated selvage have been revealed using a cold cathode cathodoluminescence detector on an optical microscope. The matrix consists mainly of $\mathrm{K}$-feldspar grains (in blue in the $\mathrm{CL}$ images) that form a fine-grained mosaic texture with straight boundaries and triple junctions at $120^{\circ}$ (Figure 8a-b). K-feldspar is characterized by a core with fine-grained perthite textures surrounded by a K-feldspar rim (Figure 8a). These boundaries are coated with thin plagioclase films or elongated grains (brown color in Figure 8a-b) that can be connected to form a branching array. Terminations of the films and elongated grains are characterized by small dihedral angles $\left(<20^{\circ}\right)$. The connection of these films also leads to the formation of plagioclase pools along grain boundaries (Figure 8a-b) or at K-feldspar triple 
junctions. Where plagioclase films are abundant, K-feldspar grains show very irregular resorbed grain boundaries (Figure 8b) and plagioclase films are connected to myrmekites pools (Figure 8ab). Finally, a large plagioclase $( \pm$ quartz) moat surrounds sillimanite and garnet porphyroblasts (Figure 8b).

\section{GARNET COMPOSITION}

To investigate the link between the textural and mineralogical features of melt-rock interaction and their compositional characteristics, major element data from multiple garnet grains were obtained by EMPA, and trace element data by LA-ICP-MS. X-ray maps and linear spot traverses were acquired to reveal the evolution of major element zoning patterns across the quartz-undersaturated selvage and granulite. Trace element mapping was performed to better inform the paragenetic context, particularly with regard to accessory minerals, and evaluate the record of geochemical mobility during garnet growth and dissolution. Major and trace element data are provided in Datasets S1 and S2, respectively, and presented in Figures 9, 10, 11, 12 and 13. . Raw trace element maps from which the profiles were extracted are available as ".csv" text file images (Dataset S3-S5). LA-ICP-MS analytical methods are provided in Appendix S1.

\subsection{Major element zoning}

Garnets are almandine - pyrope - grossular solid solutions with minor amounts of spessartine $(<0.015)$ (Dataset S1). All garnets are zoned and their composition varies with respect to their location and distance from the leucosome. In the quartz-undersaturated selvage, a polymineralic inclusion-free garnet porphyroblast in direct contact with the leucosome (Garnet A; Figure 5a) is characterized by bell-shaped zoning in grossular, with a maximum content of 0.12 in the core that decreases continuously towards the rims down to 0.03 (Figure 9a). Almandine and pyrope content increase towards the rim from 0.56 to 0.61 and 0.30 to 0.35 , respectively, which results in a constant $\mathrm{XMg}[=\mathrm{Mg} /(\mathrm{Fe}+\mathrm{Mg})]$ of $0.34-0.35$. Garnet $B$ has equivalent zoning, except that close to the polymineralic inclusions, grossular content decreases 
333 from a $700 \mu \mathrm{m}$ wide and uniform plateau at 0.12 down to 0.08 (Figure 9b). This decrease in 334 grossular content is mimicked by an increase of $X M g$ from 0.35 to 0.38 . It is noteworthy that the depleted grossular core also corresponds to the domain containing smoothed and rounded inclusions of quartz (light gray area in Figure 9b). The outer rim of Garnet B is characterized by grossular content and XMg value of 0.03 and $\sim 0.35-0.36$, respectively (Figure $9 \mathrm{~b}$ ). The resorbed outer left rim, in contact with cordierite and biotite, shows a sharp decrease in XMg down to 0.28 over a distance not greater than $100 \mu \mathrm{m}$ (Figure 5b and 9b).

$$
\text { Garnets from the quartz-saturated granulite (Garnets } C-G \text { ) show zoning profiles }
$$

comparable in shape to Garnet B from the quartz-undersaturated selvage, except that the endmember modal abundances are significantly different (compare Figure 9b and Figure 9c-g). Garnet cores in direct contact with the polymineralic inclusions are characterized by low grossular values $(0.03-0.04)$ that are similar in composition to garnet rims in contact with the matrix. Grossular content then increases towards the rim to a maximum value that is systematically located at the transition between the inclusion-bearing and inclusion-free garnet (Figure 9c-g). The maximum grossular content varies from grain to grain, from 0.095 (Garnet E) down to 0.045 (Garnet F). Finally, the inclusion-free rims show a decrease in grossular content towards the matrix to a minimum value of 0.03 , equivalent to the core compositions. $\mathrm{XMg}$ ratio profiles for all samples are relatively flat, with values evolving from 0.36-0.37 (Garnet C) to 0.41-0.44 (Garnet G) with increasing distance from the leucosome. The smallest garnet grain analyzed (Garnet F) does not follow this trend, showing a lower XMg value of 0.36 and a nearconstant grossular content of 0.03-0.04. Garnet E profile shows on its left side a sharp decrease in $\mathrm{XMg}$ from 0.40 to 0.36 , over a distance less than $100 \mu \mathrm{m}$, that is interpreted as late $\mathrm{Fe}-\mathrm{Mg}$ exchange during partial garnet breakdown into cordierite, comparable to Garnet B.

\subsection{Trace element zoning} Similar to their major element characteristics, the analyzed garnets show significant 
variations in trace element composition and zoning patterns depending on their location with respect to the leucosome. We will focus on Garnets A and B, located in the quartzundersaturated selvage, and Garnet G, located in the quartz-present host granulite. Garnet A is located directly adjacent to the leucosome, and contains the least inclusions in its core except for a few rounded quartz grains. Figures 10a, 11 and Figure S4 illustrate the key features of the trace element zoning. $\mathrm{Y}, \mathrm{Zr}, \mathrm{V}$ and heavy rare-earth elements (HREEs), from Dy to Lu, show a symmetrical bell-shaped profile without sharp discontinuities except for an abrupt increase at the rim. In contrast, light rare-earth elements (LREEs), from La to Gd, show a bowl-shaped zoning profile with a broad flat core that is mimicked by Li, P and Sc. Notably, the radial positions of broad peaks along the zoning profile are correlated for all REEs and $\mathrm{Y}$ (Figure $11)$, and there is no difference in gradient with decreasing atomic number.

Garnet B is the largest analyzed grain, with a small polyphase plagioclase + quartz inclusion in its core. It is located a few millimeters from Garnet A within the quartzundersaturated selvage but further displaced from the leucosome. Trace element map and profile are shown in Figure 10b, 12 and S4. Its zoning pattern shows the same symmetrical bellshape profile for $\mathrm{Y}, \mathrm{Zr}$ and the heaviest HREE (from $\mathrm{Yb}$ to $\mathrm{Er}$ ), but with elevated concentrations compared to Garnet A (e.g. Y $\sim 360$ vs 270 ppm; Yb $\sim 75$ vs 45 and Lu $\sim 15$ vs 6 ppm). In contrast, rim compositions are strictly identical for all elements in both samples (compare Figures 11 and 12 and S4). Because Garnets A and B are located in the same petrographic setting, we suggest that the difference in absolute concentrations reflects a sectioning effect (i.e. Garnet $A$ is not sectioned through its core) rather than a geological process. The outer rim of Garnet B is characterized by a sharp increase in $\mathrm{Y}, \mathrm{Zr}$ and HREEs, and LREEs and $\mathrm{P}$ have the same overall bowl-shaped zoning as Garnet A despite a more irregular profile that includes several narrow peaks. Concentrations in $\mathrm{La}, \mathrm{Ce}$ and $\mathrm{P}$ are significantly enriched next to the polyphase inclusion and the matrix on the left side of the profile (Figure 12). The major difference in comparison to Garnet A corresponds to a broad depletion in Dy, Ho and Tb adjacent to the polyphase inclusion located at the garnet core. This feature closely matches the grossular zoning profile (Figure 9b), 
and corresponds to the domain containing rounded inclusions of quartz.

Garnet $\mathrm{G}$ is derived from the quartz-present host granulite and is located furthest from the leucosome (Figures 4 and 5). It is the smallest analyzed grain and contains a large irregular polyphase inclusion in its core. Trace element map and profile are shown in Figure 10c, 13 and S4. Y and HREEs, from Lu to Tb, show a broad bell-shaped profile, but with maximum concentrations on average two to three times lower than the larger Garnets A and B (Figure 13). In contrast, rim compositions for all elements are once again similar for all samples. La, Ce and P show bowl-shaped profiles with a large flat core surrounded by an enriched rim. Sm (and to a lesser extent Gd) are no longer characterized by a typical bowl-shaped profile but rather mimic the grossular zoning, with a depleted core next to the polyphase inclusion (Figure 13). This similarity continues along the profile, with an identical location for the maximum Sm concentration and a core composition adjacent to the polyphase inclusion that is equivalent to the rim composition ( 2 to 3 ppm on average; Figure 13 ).

\section{PETROLOGICAL MODELING}

We use computed phase diagram sections to constrain (1) the pressure and temperature of garnet nucleation and growth, partial melting, and retrogression; and (2) the most likely processes responsible for the formation of the quartz-undersaturated selvage. For this purpose, the model system $\mathrm{Na}_{2} \mathrm{O}-\mathrm{CaO}-\mathrm{K}_{2} \mathrm{O}-\mathrm{FeO}-\mathrm{MgO}-\mathrm{Al}_{2} \mathrm{O}_{3}-\mathrm{SiO}_{2}-\mathrm{H}_{2} \mathrm{O}$ was chosen to calculate phase relationships using Perple_X 6.6.6 software (Connolly, 2005), with the thermodynamic database of (Holland \& Powell (1998), as revised in 2002). $\mathrm{TiO}_{2}$ and $\mathrm{Fe}_{2} \mathrm{O}_{3}$ where not considered in the modeling because (1) the bulk rock content of $\mathrm{TiO}_{2}$ is less than $0.6 \mathrm{wt} \%$; and (2) there is no $\mathrm{Fe}^{3+}$ bearing phase like hematite or magnetite and the amount of $\mathrm{Fe}^{3+}$ in garnet based on structural formulae is negligible. Solution models and end-member phases considered in the modeling are listed in Table S1. 


\subsection{P-T conditions of garnet nucleation and growth}

Deciphering the P-T conditions of the early garnet growth and prograde path relies essentially on the observation of garnet inclusions and the valid interpretation of garnet composition and zoning. Garnet cores are characterized by the occurrence of quartz and polyphase plagioclase-quartz inclusions, whereas the inner rim of the largest garnet grains show abundant crystallized melt inclusions. We therefore suggest that the onset of garnet growth may have occurred under sub-solidus conditions.

Garnet core compositions are typically used to retrieve the approximate P-T conditions of garnet nucleation. However we will show later that major and trace element zoning patterns and more particularly garnet core compositions have been modified, most likely as a result of post-growth re-equilbration during partial melting and retrogression. The biggest garnets located in the quartz under-saturated selvage (garnet A and B, Figure 4-5) show the least modified zoning profile, with typical bell-shape zoning in grossular (Figure 9a,b) and trace elements (Figure 11-12). Although these large garnets A and B are located in the quartz-undersaturated selvage, the presence of quartz inclusions within their cores suggests that the onset of garnet growth occurred under quartz-saturated conditions. We therefore suggest that the loss of $\mathrm{SiO}_{2}$ and the formation of the quartz-undersaturated layer is a post-garnet growth process. Hence, to retrieve the P-T conditions of early garnet growth and constrain the prograde path, we have computed a P-T phase diagram section with a XRF bulk composition corresponding to the quartzsaturated domain composition (Table 1 and Figure 14). The phase diagram section has been contoured for grossular content, $\mathrm{XMg}(=\mathrm{MgO} / \mathrm{MgO}+\mathrm{FeO})$ in garnet and garnet modes (Figure 14).

The amount of water is known to be a critical variable when modeling phase relations in melt-bearing systems (e.g. White et al., 2001). A classic strategy to estimate the amount of water in melt-bearing systems consists of adding enough water to the system such that the solidus is water-saturated. However, if we follow this approach, high-grossular garnet core compositions cannot be reproduced. Therefore, the system was kept water-undersaturated, such that measured garnet core compositions (i.e. the highest grossular values) are predictable, and 
440 the amount of major rock-forming phases are consistent with observed mineral modes. The amount of water was adjusted and fixed at $1.67 \mathrm{~mol} \%(0.025 \mathrm{~mol}$ or $0.46 \mathrm{wt} \%)$. With this low water condition, partial melting was restricted to temperatures higher than $\sim 750^{\circ} \mathrm{C}$ (Figure 14) The maximum grossular content of $\sim 0.12$, coupled with the corresponding XMg $(0.35$ 0.38), allow estimating the minimum P-T conditions of garnet growth at $\sim 1.2 \mathrm{GPa}, 675^{\circ} \mathrm{C}$ (black circles with letters in Figure 14). This corresponds to sub-solidus conditions where garnet is in equilibrium with plagioclase, biotite, kyanite and muscovite. Although these last two phases have never been observed as inclusions in garnet, the predicted plagioclase composition $\left(\mathrm{An}_{76^{-}}\right.$ $\left.A b_{23}\right)$ is consistent with the high anorthite compositions measured in plagioclase inclusions. Furthermore, melt-inclusions are absent in the high grossular cores (Figure 5), whereas they are abundant in the low-grossular rims. This observation is consistent with an early garnet nucleation and growth under sub-solidus conditions with peak metamorphism and garnet rim crystallization occurring in melt-present conditions.

In Figure 14, we report the composition of Garnet C to G, located in the quartz-saturated domain, with the highest grossular content and corresponding XMg values (grey circles with letters in Figure 14). The maximum grossular content, preserved in the inner rim at the transition between the inclusion-bearing and inclusion-free domains, varies from grain to grain from 0.095 (Garnet E) down to 0.04 (Garnet F) and XMg from 0.36 (Garnet C) to 0.43 (Garnet G)

(Figure 9). The inferred P-T conditions vary from $\sim 1.3 \mathrm{GPa}$ and $720^{\circ} \mathrm{C}$ to $0.85 \mathrm{GPa}$ and $780^{\circ} \mathrm{C}$ corresponding approximately to the P-T conditions of garnet nucleation and peak metamorphism / partial melting, respectively (see Section 5.2 below). We suggest that this could reflect the progressive and incomplete re-equilibration of garnet during a prograde (heating/decompression) path from $\sim 1.2 \mathrm{GPa}$ and $675^{\circ} \mathrm{C}$ down to $0.8 \mathrm{GPa}$ and $790^{\circ} \mathrm{C}$. During this 


\subsection{P-T conditions of peak metamorphism, partial melting and retrogression}

The computed P-T phase diagram in Figure 14 shows the classic phase relations for partially melted aluminous-rich pelites (e.g. White et al., 2001), with the divariant muscovitedehydration melting equilibrium at high pressure $(1.2>\mathrm{P}>0.9 \mathrm{GPa})$ and the biotite-dehydration melting equilibrium that produces garnet and cordierite at lower pressure $(0.8>\mathrm{P}>0.6 \mathrm{GPa})$. Between these two divariant narrow fields lies a trivariant assemblage with garnet, biotite, sillimanite, K-feldspar, quartz and melt in equilibrium, between 770 and $820^{\circ} \mathrm{C}$ (Figure 14). This calculated assemblage is consistent with the observed assemblage in the quartz-saturated granulite. Garnet core and rim compositions in direct contact with the polyphased plagioclasequartz inclusions (ca. $3 \%$ grossular and $\mathrm{XMg}=0.36-0.44$ ) give consistent $\mathrm{P}-\mathrm{T}$ conditions of $0.8 \pm$ $0.05 \mathrm{GPa}$ and $790 \pm 20{ }^{\circ} \mathrm{C}$ (white circles with letters in Figure 14), with the predicted XMg of biotite $(0.70)$ consistent with the measured biotite composition. We interpret these estimates to reflect partial melting during the development of the steeply dipping $S_{2}$ granulite-grade gneissic foliation. As discussed in Section 7.2, however, the garnet trace element distribution indicates that core compositions may have been affected by post-growth re-equilibration.

Retrogression in the quartz-saturated domain is characterized by the local development of cordierite at the expense of garnet and sillimanite (Figure $4 \mathrm{~b}$ ), through reaction (1). This local and partial retrogression is also evidenced by the sharp decrease in XMg from 0.40 to 0.36 , at constant grossular content $(\sim 0.30)$ (Figure 9e, outer rim of Garnet E). Figure 14 shows that the development of cordierite and the decrease in $\mathrm{XMg}$, at almost constant grossular content, would require further isothermal decompression at or below $0.7 \mathrm{GPa}$ in the garnet + cordierite + sillimanite + K-feldspar + plagioclase + quartz stability field.

\subsection{Formation of the quartz-undersaturated selvage via melt-driven metasomatism}

In migmatites, the formation of quartz-undersaturated assemblages has been interpreted as characteristics of advance quartz-consuming reactions during partial melting coupled with local melt extraction (Fitzsimons, 1996; Owen, 1991). Alternative models consist of producing 19 
the quartz-depleted selvage by small-scale silica metasomatism between the host rock and a quartz vein (Penniston-Dorland \& Ferry, 2008) or a silica-rich leucosome formed after melt segregation and transport (Dunkley, Clarke \& Harley, 1999). In the later case, selvage formation is a post-anatectic process rather than being directly related to partial melting of the host-rock (Lin \& Sawyer, 2019). In the following section, we model and show that element exchange (diffusion-metasomatism) between the segregated melt (leucosome) and the host granulite is likely to be responsible for the formation of the quartz-depleted selvage during post-peak decompression.

Following the approach of White and Powell (2010), we investigate through phase equilibria modeling the melt-driven metasomatism and more particularly the role of diffusion, between melt-rich domains (leucosome) and the host granulite, on the formation of the selvage. Our conceptual model is similar to Lin \& Sawyer (2019) and requires a first stage of partial melting and melt segregation to produce two subsystems corresponding to the quartz-saturated domain ( residue) and the melt domain. At the P-T conditions of partial melting and melt segregation (i.e. $0.8 \mathrm{GPa}$ and $790^{\circ} \mathrm{C}$ ), chemical potentials are the same in the solid phases and the melt of both domains, if thermodynamic equilibrium is maintained. The second stage corresponds to decompression into the cordierite-bearing stability field below $0.7 \mathrm{GPa}$. As pressure decreases, chemical potential evolve independently in both subsystems. Therefore, diffusion of components is driven by the chemical potential gradient established at the interface between the quartz-saturated residue and the leucosome.

In order to determine the direction of diffusion, we have computed the chemical potentials of $\mathrm{H}_{2} \mathrm{O}, \mathrm{SiO}_{2}, \mathrm{CaO}$ and $\mathrm{K}_{2} \mathrm{O}$ for the quartz-saturated and melt domains along an isothermal decompression path from 0.8 to $0.5 \mathrm{GPa}$ at $790^{\circ} \mathrm{C}$ (Figure 15). The chemical potentials in the melt domain were determined using the chemical composition of melt produced at $0.8 \mathrm{GPa}$ and $790^{\circ} \mathrm{C}$ (Table 1 ). Chemical potential of the selected components were computed separately for each sub-systems (segregated melt and residue) by assuming that during decompression these two sub-systems are closed and chemically isolated from each other (Figure 15). This implies that there is no interaction or mass transfer between the two 20 
subsystems. This ideal chemical isolation model is in a strict sense impossible because the two sub-systems are physically in contact and therefore chemical interactions are expected at some scale and chemical potential will continuously evolve with ongoing decompression due to diffusive mass transfer (White \& Powell, 2010). However, our approach can be used at first order to determine the direction of transport of the four selected species if chemical interaction at the interface is permitted. During decompression, the chemical potentials of $\mathrm{H}_{2} \mathrm{O}, \mathrm{CaO}, \mathrm{K}_{2} \mathrm{O}$ and $\mathrm{Na}_{2} \mathrm{O}\left(\mathrm{Na}_{2} \mathrm{O}\right.$ not shown in Figure 15$)$ become higher in the melt segregated domain (leucosome) than in the residue. In contrast, the chemical potential of $\mathrm{SiO}_{2}$ is lower in the melt than in the residue. This suggests that species such as $\mathrm{H}_{2} \mathrm{O}, \mathrm{CaO}, \mathrm{K}_{2} \mathrm{O}$ and $\mathrm{Na}_{2} \mathrm{O}$ will diffuse from the melt into the host residue whereas $\mathrm{SiO}_{2}$ is transferred from the host residue into the adjacent melt domain.

To model the effect of metasomatism and pressure on phase relations, a P-X phase diagram section was computed at $790^{\circ} \mathrm{C}$ (Figure 16). The initial amounts of $\mathrm{CaO}$ and $\mathrm{Na}_{2} \mathrm{O}$ are very low ( $<1.3$ and $0.6 \mathrm{wt} \%$, respectively) and do not significantly influence the phase relations. Therefore, variations in $\mathrm{Na}_{2} \mathrm{O}$ and $\mathrm{CaO}$ content are not considered. The bulk composition for $\mathrm{X}=$ 0 corresponds the quartz-saturated host-rock composition prior to any mass transfer. The bulk composition for $\mathrm{X}=1$ is obtained assuming a gain in $\mathrm{H}_{2} \mathrm{O}$ of $200 \%\left(\mathrm{H}_{2} \mathrm{O}=0.075 \mathrm{~mol}\right)$ and a $\mathrm{SiO}_{2}$ loss of $55 \%\left(\mathrm{SiO}_{2}=0.342 \mathrm{~mol}\right)$. These values are arbitrary. Bulk compositions used are provided in Table 1.

Figure 16 shows the location of the two main low variance $(\mathrm{V}=2)$ retrogression equilibria that have been observed in the quartz-saturated domain and quartz-absent selvage: Grt + Sil + $\mathrm{Qz} \pm \mathrm{Bt}=\mathrm{Crd}+\mathrm{L}(2)$ and $\mathrm{Grt}+\mathrm{Sil} \pm \mathrm{Bt}=\mathrm{Crd}+\mathrm{Spl}+\mathrm{L}(3)$ at $0.72 \mathrm{GPa}$ and $0.55 \mathrm{GPa}$ respectively. These divariant equilibria together with their related trivariant assemblage are used to locate the quartz-out, cordierite-in and spinel-in boundaries (Figure 16). The formation of selvage assemblage $(\mathrm{Crd}+\mathrm{Spl}+\mathrm{Sil}+\mathrm{L} \pm \mathrm{Grt} / \mathrm{Bt})$ requires a decompression below $0.55 \mathrm{GPa}$ and a bulk composition with $X$ ranging from $\sim 0.65$ to 0.8 . Taking a value of $X=0.7$, mass transfer required to produce the selvage from the host quartz-saturated granulite corresponds to a relative gain of 
547 about $140 \%$ of $\mathrm{H}_{2} \mathrm{O}$ coupled with a relative loss of $47 \%$ of $\mathrm{SiO}_{2}$. The P-X phase diagram is also 548 contoured for garnet mode (Figure 16). As expected, decompression is associated with garnet 549 breakdown, but at pressures above the cordierite-in boundary $(\mathrm{P}>0.72 \mathrm{GPa})$, mass transfer $\left(\mathrm{SiO}_{2}\right.$ 550 loss coupled with $\mathrm{H}_{2} \mathrm{O}$ gain) induces a slight increase in garnet mode, from 12 to 17 vol\%. This mineralogical evolution is consistent with the observation of a higher modal abundance of garnet 552 in the metasomatic selvage with respect to the host granulite.

Based on the estimation of mass transfer required to produce the quartz-undersaturated selvage, a P-T phase diagram section has been computed with an estimated selvage composition (Figure 17 and table 1). This composition corresponds to $X=0.70$ in Figure 16 . Figure 17 shows the location in a P-T space of the two main low-variance retrogression reactions (2) and (3) and the position of the quartz-out, cordierite-in and spinel-in lines. Once again, the selvage formation is consistent with a decompression from about $0.8 \mathrm{GPa}$ down to $0.5 \mathrm{GPa}$ at temperatures greater than $750^{\circ} \mathrm{C}$.

\section{U-TH-PB MONAZITE AND ZIRCON GEOCHRONOLOGY}

Monazite and zircon geochronology were acquired to establish a temporal framework for meltrock interactions and the relationship of garnet growth and dissolution to the accessory mineral evolution. Chemical zoning in monazite and zircon were first characterised via X-ray mapping and cathodoluminescence respectively. In situ U-Th- $\mathrm{Pb}$ monazite and zircon ages were then acquired by laser ablation inductively coupled plasma-mass spectrometry (LA-ICP-MS). Sample preparation and operational procedures for all techniques are described in Hurai, Paquette, Huraiová \& Kronečný (2010) and Paquette et al. (2014) and presented in Appendix S2. U-Th-Pb geochronological data are provided in Dataset S6. 
572

573

574

575

576

577

578

579

\subsection{Textural features and dates}

Monazite is abundant in both quartz saturated and undersaturated domains but is totally absent in the leucosome. The analyzed monazites range in size from 50 to $250 \mu \mathrm{m}$ and occur in the matrix, at grain boundaries and included in sillimanite and plagioclase (M1-2-13), in the vicinity of garnet and within the retrograde cordierite moat (M3-6-4-8-9-10-11-12) (Figure 18a). Monazite grains $M 3, M 6$ and $M 12$, located in cordierite moats, have an unusual worm-like shape that mimics the embayed garnet rim (Figure 18c). Only one grain (M7) was found included in a garnet rim.

All monazite grains are chemically homogeneous (Y-poor) (Figure 18b,c) except for two grains (M9 and M10) that show a subtle zoning with high Th domains. Grains located in the cordierite moat show discrete and discontinuous micron-scale Y-rich rims (Figure 18c) whereas those included in other phases are devoid of such overgrowths (Figure 18b). These observations suggest that the crystallization of the low $\mathrm{Y}$ grains might precede or be coeval with the peak assemblage garnet (rim), sillimanite, biotite, plagioclase, K-feldspar \pm quartz. The crystallization of discrete Y-rich monazite overgrowths in the vicinity of garnet porphyroblasts partially retrogressed into cordierite has been previously interpreted as an indicator of accessory phase growth during garnet breakdown (Mahan et al., 2006). We suggest that $Y$ overgrowths are also contemporaneous with cordierite crystallization and selvage formation.

Ten homogeneous Y-poor grains were analyzed for a total of 39 analyses (Dataset S6). The Y-rich overgrowths were not analyzed due to their small size in order to avoid mixing during ablation. In a ${ }^{206} \mathrm{~Pb} /{ }^{238} \mathrm{U}$ versus ${ }^{208} \mathrm{~Pb} /{ }^{232} \mathrm{Th}$ diagram all analyses are concordant or sub-concordant (Figure 19a). Excluding six analyses (see Dataset S6) gives a concordia age of $2061 \pm 6 \mathrm{Ma}$ $(M S W D(C+E)=1.3)$. The weighted mean of ${ }^{208} \mathrm{~Pb} /{ }^{232} \mathrm{Th}$ dates gives an age of $2069 \pm 8 \mathrm{Ma}(\mathrm{MSWD}=$ 1.6) (Figure 19b). The ${ }^{208} \mathrm{~Pb} /{ }^{232} \mathrm{Th}$ dates show no systematic variation with textural location (see Figure $18 \mathrm{a}$ and Dataset S6), and more specifically, monazite included in garnet (M7) is not statistically different from matrix grains (Figure 19). The date of $2.06 \mathrm{Ga}$ is interpreted as the age of partial melting at $0.8 \pm 0.05 \mathrm{GPa}$ and $790 \pm 20^{\circ} \mathrm{C}$, before decompression responsible for 
partial garnet breakdown and crystallization of small Y-rich overgrowths.

Zircons are rare and do not exceed $50 \mu \mathrm{m}$ in diameter. They are translucent with a rounded shape typical of zircons recrystallized under granulite facies conditions. Fourteen analyses were performed on fourteen grains (Dataset S6). They do not show significant zoning in cathodoluminescence. A first group of 7 analyses are concordant and gives a concordia age of $2072 \pm 7 \mathrm{Ma}(\mathrm{MSWD}(\mathrm{C}+\mathrm{E})=2.3)($ Figure 19c). A second group of 4 analysis are discordant and when plotted together with the previous 7 analysis, it defines a discordia with an upper intercept at $2073 \pm 11 \mathrm{Ma}(M S W D=2.0)$. The last group, consists of 4 analyses that do not match the previous tow identified clusters (white ellipses in Figure 19), with ${ }^{207} \mathrm{~Pb} /{ }^{206} \mathrm{~Pb}$ dates that range from 2.07 to $2.33 \mathrm{Ga}$ and one concordant analysis at $2192 \pm 15 \mathrm{Ma}$. The $2.07 \mathrm{Ga}$ date is similar to that obtained for monazite and is interpreted as the age of partial melting. The remaining three analyses are interpreted as inherited ages.

\section{DISCUSSION}

Petrological and micro-textural analysis carried out across the interface between the leucosome and the host-granulite shows a systematic and consistent evolution in mineral paragenesis, micro-textures, garnet grain size and composition (major and trace element) with the distance from the leucosome. The studied sample is therefore used to discuss small-scale melt-rock interaction processes. In this section, we will first summarize the petrological model of formation of the migmatite and more particularly the quartz-undersaturated selvage at the interface between the segregated melt (leucosome) and the partially melted host granulite. Based on this petrological evolution, we will discuss the significance of major and trace element zonation observed in garnet. 


\subsection{Petrological model of migmatite and quartz-undersaturated selvage formation through}

\section{diffusion metasomatism}

The phase relation modeling performed suggests that the onset of garnet crystallization occurred under subsolidus conditions at high pressure $(\mathrm{P} \sim 1.2 \mathrm{GPa})$ and temperatures of 675 to $700^{\circ} \mathrm{C}$. These P-T conditions, that were estimated using the maximum grossular content of garnet cores and anorthite content of plagioclase inclusions, are consistent with a steady state geotherm considering average crustal thermal parameters (thermal conductivity $\mathrm{k}=3 \mathrm{~W} \cdot \mathrm{m}^{-1} \cdot \mathrm{K}^{-1}$, heat production $\mathrm{A}=0.75 \mu \mathrm{W} \cdot \mathrm{m}^{-3}$, a mantle heat flow $\mathrm{Q}=30 \mathrm{~mW}$, a density $\rho=2.7 \mathrm{~kg} \cdot \mathrm{m}^{-3}$ ) at a depth of $45 \mathrm{~km}(1.2 \mathrm{GPa})$. We suggest that the gently dipping gneissic foliation $\left(\mathrm{S}_{1}\right)$ that trends NE-SW (Figures $2 \mathrm{~b}$ and S1) may be occurred at to these conditions and may correspond to a crustal thickening event. This interpretation is also supported by the observation of quartz and plagioclase inclusions trails, defining a S1 foliation, in the high-grossular garnet cores (Figure 3a).

Partial melting occurred at $0.8 \mathrm{GPa}$ and $790^{\circ} \mathrm{C}$ at $\sim 2.06-2.07 \mathrm{Ga}$. The former presence of melt at peak metamorphic conditions can reliably be inferred from the occurrence of peritectic garnet, produced by biotite-dehydration melting (1) (Figures 4-5) and the presence of crystallized melt inclusions within the garnet (Figure 6). Interstitial elongated films along grains boundaries and pools at the triple junction (Figure 8) are alternative criteria diagnostic of the former presence of melt and melt movement at the grain scale (Holness \& Sawyer, 2008; Sawyer, 2001; Stuart, Piazolo \& Daczko, 2018; Vernon, 2011). The interstitial plagioclase may represent the plagioclase component crystallized from the melt (Hasalová, Schulmann, Lexa, Štípská \& Hroda, 2008; Stuart et al., 2018). The corroded K-feldspar grains and the crystallization of plagioclase and myrmekite (figure 8) are interpreted as the result of K-feldspar dissolution during the interaction between the host rock and a migrating melt (Hasalová et al., 2008). We suggest that the connection between the leucosome and the host-granulite via the grain boundary melt array favored efficient small-scale mass transfer in and out of the host-granulite to produce the quartz-undersaturated selvage. 
coupled with melt segregation are responsible for the establishment of chemical potential gradients between the leucosome and the host-granulite. Chemical potential gradients drive diffusive metasomatism of species between the two reservoirs and the formation of the quartzundersaturated selvage at the interface. The modeling suggests that, during post-peak decompression from 0.8 to $\sim 0.5 \mathrm{GPa}$ at $790^{\circ} \mathrm{C}$, species like $\mathrm{H}_{2} \mathrm{O}, \mathrm{CaO}$ and $\mathrm{Na}_{2} \mathrm{O}$ will be transferred from the leucosome to the host-rock while $\mathrm{SiO}_{2}$ had an opposite diffusion direction, going from the host-rock to the leucosome. Phase diagrams in figure 16 and 17 show that mass transfer coupled with decompression resulted in the partial transformation of the quartz-saturated peak metamorphic assemblages (Grt, Bt, Sil, Qz + L) into a quartz-undersaturated assemblage with cordierite and spinel (see location of Qz-out, Crd-in and Spl in Figure 16). Formation of the quartz-undersaturated selvage via melt-driven metasomatism (ie. $\mathrm{SiO}_{2}$ loss), is well supported by the absence of quartz in the matrix and the observation of quartz only as inclusions in garnet cores. This observation rules out the possibility that the gneissic layering and more particularly the quartz-absent selvage is inherited from the sedimentary protolith. The phase diagram shows that further mass transfer and decompression below $0.5 \mathrm{GPa}$ could result in the formation of corundum-bearing assemblage. modeled mass transfer direction and the formation of the selvage:

(1) The quartz-undersaturated selvage, where local mass-transfer is inferred as the dominant process, is characterized by larger garnet grain sizes. This is consistent with modeled garnet modes in Figure 16, that show an isobaric and isothermal increase in garnet abundance at $0.8 \mathrm{GPa}$, only due to mass transfer $\left(\mathrm{SiO}_{2}\right.$ gain and $\mathrm{H}_{2} \mathrm{O}$ loss $)$.

(2) Diffusion of water from the melt into the host-granulite will favor the crystallization of anhydrous products in the melt, producing almost an anhydrous leucosome, while the 676 hydrous-phases like biotite and cordierite. This observation is very consistent with results from 
White and Powell (2010) who also predicted that the diffusion of $\mathrm{H}_{2} \mathrm{O}$ into the residue will be responsible for the formation of anhydrous leucosomes during an isobaric cooling under granulite facies conditions.

(3) Diffusion of other mobile species like $\mathrm{CaO}, \mathrm{Na}_{2} \mathrm{O}$ and $\mathrm{K}_{2} \mathrm{O}$, from the leucosome into the selvage is indirectly supported by the mineralogical composition of the leucosome that consists mostly of quartz with very minor K-feldspar and almost no plagioclase. It is well known that leucosomes in migmatites do not have the expected minimum granitic composition (Ashworth \& McLellan, 1985) due to post-anatectic magmatic differentiation processes. However, following Olsen and Grant (1991), who performed a mass-balance (isocon) analysis on leucosomes, we suggest that the quartz-rich and K-feldspar and plagioclase-poor leucosomes most likely formed by loss of $\mathrm{Na}_{2} \mathrm{O}$ and $\mathrm{CaO}$ by diffusion.

(4) Diffusion of $\mathrm{K}_{2} \mathrm{O}$ into the host-rock is likely to be responsible for the formation of the distinct inclusion-free outer-rim of K-feldspar located in the selvage (Figure 8).

(5) The introduction of $\mathrm{a} \mathrm{Na}_{2} \mathrm{O} / \mathrm{CaO}$-rich fluid or melt into the selvage, is consistent with the observation of plagioclase films and pools along K-feldspar grain boundaries (Figure 8). The formation of myrmekite in the selvage is also consistent with a fluid or melt mediated $\mathrm{Na}-\mathrm{Ca}$ replacement of K-feldspar by plagioclase (Yuguchi \& Nishiyama, 2008).

Melt segregation and the development of the selvage defines a steeply deeping $S_{2}$ gneissic layering that transposes the previous $\mathrm{S}_{1}$ fabric (Figure 3 and Figure S1). Kinematic analysis of the $D_{2}$ high strain is consistent with NNW-SSE shortening and a bulk dextral sense of shear. We conclude that melt transfer and metasomatism may have been enhanced by D2 transpressive deformation.

\subsection{Major and trace element behavior during partial melting and retrograde melt-rock} interaction

The studied sample preserves mineralogical and textural evidence of prograde partial melting and melt segregation, near-isothermal decompression and melt-driven metasomatism. With respect to other phases, garnet has the tremendous advantage to preserve records of these 27 
various processes via its chemical zoning in major and trace elements, because of the slow rates of intracrystalline diffusion (e.g. Carlson, 2006). However, in order to interpret accurately these zoning patterns in terms of large-scale and long-term geological/geodynamic processes, we have to understand the small-scale processes that control the behavior of major and trace elements during garnet nucleation, growth, breakdown and re-equilibration (George \& Gaidies, 2017 and references therein). Although the zoning features varies from garnet to garnet, they show systematic variations and similarities that can be correlated with the P-T-X evolution and petrographic setting. Via a qualitative analysis of zoning profiles, and previous work by others cited below, we suggest these features reflect the superposition of at least three grain-scale processes that control the intra- and intergranular mobility of chemical components (major and trace elements).

\section{Evidence of fast intergranular mobility of elements, including REE, and rock-wide equilibrium} The P-T evolution of the studied sample occurred at high temperature $\left(>650^{\circ} \mathrm{C}\right)$ and in the presence of melt, from peak-metamorphic conditions $\left(0.8 \mathrm{GPa} ; 790^{\circ} \mathrm{C}\right)$ to the conditions of selvage formation $\left(\sim 0.5 \mathrm{GPa} ; 800^{\circ} \mathrm{C}\right)$. Therefore, the high mobility of major and to a lesser extent trace elements is expected. We report below evidence of fast intergranular mobility of elements, including REE, and rock-wide equilibrium.

Rock-wide equilibrium and by extension fast inter-granular transport of major and trace elements during peak metamorphic conditions and subsequent melt-driven metasomatism is best demonstrated using garnet rim compositions. Although the analyzed garnets are located in different petrographic settings (within the quartz-undersaturated selvage or in the hostgranulite displaced from the leucosome) and vary markedly in grain size and morphology, their outermost rims share consistent major element (grossular content $=3 \%$; Figure 9 ) and trace element compositions ( $\mathrm{Y}$ and REEs; Figure 11-13). This consistency in major element composition of the rims permits an accurate estimation of peak metamorphic conditions at $0.8 \mathrm{GPa}$ and $790^{\circ} \mathrm{C}$ (Figure 14). 
The length scale of equilibration during garnet growth, which is related to the degree of mobility of major and trace elements through the intergranular matrix, can be evaluated using the REE zoning pattern (Moore et al., 2013; Skora et al., 2006). In both studies, these authors have shown a dependency of REE distribution on atomic number in large and early nucleating garnets. Such garnets are characterized by pronounced central peaks for $Y$ and HREEs (Lu to Er), central peaks and annular maxima for MREEs (Ho, Dy), and well defined annular maxima for LREEs ( $\mathrm{Tb}$ to $\mathrm{Nd}$ ). This distribution is driven by diffusion-limited uptake that evolves during garnet growth. With increasing temperature, intergranular diffusivities increase progressively as garnet grows, but with more rapid diffusion for HREEs compared to LREEs (Moore et al., 2013; Skora et al., 2006). However, this dependency of REE distribution with atomic number is less valid at high temperature. Numerical modeling of garnet zoning along a temperature-time path performed by Moore et al. (2013) demonstrates that a uniform bell-shaped distribution for all REEs is consistent with garnet nucleation and growth at high temperature, whereas at lower temperature a sharp central peak with an annular maximum would be expected (see Figure 19 and Figure 20b in Moore et al. (2013)). From these previous studies, we can conclude that a uniform distribution for all REEs is the result of rapid intergranular diffusion that strongly minimizes the development of concentration gradients in the matrix surrounding the growing garnet.

All studied garnets are characterized by a bell-shape distribution for $Y$ and REEs, ranging from Lu to Dy $( \pm \mathrm{Tb})$, with a strong correlation between the radial positions of all peaks. This distribution is consistent with a progressive depletion of the matrix in $Y$ and REEs (Lu-Dy) due to Rayleigh fractionation with an unchanging mineral assemblage (Moore et al., 2013; Otamendi et al., 2002). Although the inferred P-T path in Figure 14 suggests that the onset of garnet growth may have occurred under sub-solidus conditions prior to muscovite dehydration, we instead suggest that the majority of garnet growth occurred via biotite dehydration melting in the trivariant NaCaKFMASH stability field Bio - L - Gt - Kf - sill - pl - q at a temperature greater than $\sim 760^{\circ} \mathrm{C}$. The uniform bell-shaped distribution for REEs, ranging from Lu to Dy, is consistent with 
rapid intergranular diffusivities.

All garnet grains are characterized by (1) the absence of progressive outwards migration of REE peak locations with decreasing atomic number; and (2) the lack of a central peak for LREEs between La and Gd. Instead, they show a large LREE-depleted core of constant composition surrounded by an enriched rim. This transition from bell- to bowl-shaped profiles with decreasing atomic number is similar to an example reported by Raimondo et al. (2017) from a metasomatic shear zone in central Australia. Both observations (1) and (2) are once again indicative of fast intergranular mobility and rock-wide equilibrium during garnet growth, without significant differences in diffusivity between HREEs and LREEs. However, we will see below that the bowl-shaped profile could also be related, or at least accentuated, by a post-growth modification.

Following Raimondo et al. (2017) and Konrad-Schmolke et al. (2008), we suggest that the REE zoning reflects a typical Rayleigh fractionation model. As garnet nucleates and grows at high temperature $\left(\mathrm{T}>750^{\circ} \mathrm{C}\right)$, the matrix is progressively depleted in HREEs on a large scale due to the presence of melt along grain boundaries that favor fast element mobility and rock-wide equilibration. Simultaneously, the matrix is passively enriched in LREE on a rock-wide scale due to the low garnet/matrix partition coefficients for LREEs (Moore et al., 2013). The rapid intergranular mobility for all REEs with respect to garnet growth, without any dependence on atomic number, precludes the establishment of diffusion gradients in the matrix, resulting in smooth core-to-rim zoning and a transition from bell-shaped HREE to bowl-shaped LREE profiles.

Small garnets located in the quartz-saturated host granulite (e.g. Garnet G) are characterized by a significantly HREE-depleted composition compared to large garnets located in the quartz-undersaturated selvage adjacent to the leucosome (Garnets A and B), whereas their LREE content remains similar. This discrepancy in REE concentrations could be related to a later nucleation of garnets located in the quartz-present host granulite. Assuming a rapid intergranular mobility and rock-wide equilibration for REEs, the early nucleation and enhanced growth of garnet in proximity to the leucosome may have induced a bulk-rock HREE depletion at 30 
the scale of the distance between Garnet A and Garnet G $(\sim 7 \mathrm{~cm})$. In contrast, the small garnet/matrix LREE partitioning coefficient has a negligible effect on the bulk rock composition, resulting in an approximately constant LREE concentration for garnet regardless its nucleation and growth history.

Post-growth intragranular diffusion of major and trace elements

Calcium maps and profiles from Garnets B-G reveal that their prograde growth zoning is modified bear the inner core inclusions. This post-growth modification resulted in chemical reequilibration of the grossular content to varying degrees, depending on the location of the garnet with respect to the quartz-undersaturated selvage and the host granulite. In the quartzsaturated host granulite, the smallest garnets (which also contain the biggest polyphase inclusions) show a complete (Garnet F) or partial re-equilibration (Garnets C, D, E, G) of the garnet core in contact with the inclusions, with grossular content decreasing to $3 \%$, corresponding to the rim composition. This suggests that post-growth modification occurred near peak P-T conditions $\left(0.8 \mathrm{GPa} ; 790^{\circ} \mathrm{C}\right)$. Located in the quartz-undersaturated selvage, the largest analyzed grain (Garnet B) also shows post-growth modification of bell-shaped Ca zoning, but chemical re-equilibration at peak-metamorphic conditions was only partial, with a minimum grossular content of $8 \%$ in the garnet core.

The modification of garnet cores in contact with polyphase inclusions and their strong similarity with matrix compositions requires a pervasive connectivity to permit such rock-wide re-equilibration to proceed. Both X-ray tomography (Figure 7) and LA-ICP-MS mapping (e.g. linear features highlighted in Li map; Figure 10) reveal the presence of a network of open channels and re-healed cracks that may have acted as potential connecting pathways. These features confirm that the garnet core was not isolated or armored from the matrix, but was rather freely accessible to the extent that fluid access along these discrete open fractures or larger conduits (Figure 7) may favor cation transport and garnet re-equilibration. 
812 Furthermore, we suggest that REEs are also susceptible to the post-growth re-equilibration process. In contact with the polyphase inclusions in Garnet B, the bell-shaped HREE profile is modified with a decrease in Ho, Dy and Tb that correlates with the Ca zoning (Figure 12). The remaining HREEs are apparently unaffected by this modification, whereas the modification of LREEs such as Sm, Gd, La and Ce is more challenging to interpret. This is largely because the bowl-shaped profile for Sm and Gd, as described above, could also be enhanced by a depletion in LREEs next to the inner core inclusions. However, Grain G does show a pronounced depletion in LREEs at the garnet core, resulting in zoning that closely mimics the Ca distribution (compare Figs $9 \mathrm{~g}$ and 13$)$. Unlike Grain B, the absence of significant depletion in Ho, Dy and Tb, coupled with its lower HREE content and well-preserved bell-shaped HREE profile, may support the interpretation that Grain G represents a late nucleating garnet in the host granulite at peak metamorphic condition. Post-growth modification proceeded at a lower temperature where only LREE remained mobile, in the presence of $\mathrm{F}, \mathrm{Cl}$ and/or P complexes (Ague, 2017; Migdisov, Williams-Jones \& Wagner, 2009; Williams-Jones, Migdisov \& Samson, 2012). Alternatively, it may suggest that selective REE mobility is coupled to Ca substitution via retrograde garnetplagioclase exchange that favors LREE over HREE according to kinetic controls and element compatibility.

\section{Role of changes in accessory phases and major rock-forming minerals} In the studied sample, the LREE + P whole rock budget is largely controlled by the stability of monazite. As such, an approximately constant LREE concentration for garnet whatever its nucleation and growth history, coupled with a smooth bowl-shaped LREE + P profile prior to post-growth modification (i.e. Garnet A; Figure 13), suggests that monazite did not grow on the prograde path. Bulk rock fractionation of this kind is incompatible with garnet-monazite partitioning relationships if their growth was coeval (Warren et al., 2019). Rather, the apparent lack of monazite competition for LREE + P throughout the garnet growth history necessitates that monazite first appeared at peak conditions, consistent with the U-Pb age interpretation 
documented previously and further explained below.

Superimposed on the bowl-shaped LREE profile, the rims of Garnets B and G show a sharp coincident enrichment in $\mathrm{Ce}$, La and $\mathrm{P}$ where garnet is in contact with the matrix assemblage consisting of plagioclase and biotite. The same sharp enrichment is observed next to polyphase plagioclase and quartz inclusions located in garnet cores. There are two possibilities for explaining LREE enrichment. We suggest that these sharp enrichments may reflect modification of garnet zoning during post-peak breakdown of monazite. This interpretation is consistent with the pervasive occurrence of thin Y-rich overgrowths on monazite located in the matrix (Figure 18c), which may represent dissolution-precipitation events during the retrograde evolution. Plagioclase breakdown may also contribute to the LREE enrichment since garnet rims are locally enriched in large ion lithophile elements (LILEs) such as $\mathrm{Ba}$ and $\mathrm{Sr}$, further suggesting that post-peak garnet-plagioclase exchange is responsible for the modified grossular zoning and that monazite ages reflect the timing of partial melting prior to breakdown on the retrograde path.

The outermost rims of garnets are characterized by a sharp increase in $Y$ and HREEs along grain boundaries (Figures 10-13). This local enrichment is interpreted to be the result of partial garnet breakdown during decompression via reactions (2) and (3) and back-diffusion of elements that strongly partition into garnet with respect to the matrix. Notably, the absence of sharp HREE and $Y$ enrichment in core domains, despite an apparently pervasive matrix connectivity during post-growth re-equilibration and simultaneous monazite replacement, confirms that garnet resorption must have post-dated these events.

Similar to the HREEs, Zr zoning is radial in all garnets except for sharp spikes adjacent to grain boundaries (figure S4). There are no satellite peaks or annular maxima indicative of zircon breakdown, nor are there any pronounced depletions indicative of sudden zircon crystallization. This suggests that zircon grew on the prograde P-T path, with the bulk rock Zr budget progressively depleted as zircon and garnet grew under rock-wide equilibrium. The distribution of $\mathrm{U}-\mathrm{Pb}$ dates supports this interpretation, with concordant zircon analyses at $2.07 \mathrm{Ga}$ being 
similar to the $2.06 \mathrm{Ga}$ monazite age inferred to represent peak metamorphism and partial melting. Rimward spikes in $\mathrm{Zr}$ are coincident with the HREE and $\mathrm{Y}$ enrichment noted above and slope away from the grain boundary, thus most likely due to garnet resorption rather than zircon breakdown.

\section{CONCLUSIONS}

The petrological and geochemical investigations of this partially melted granulite highlight the complexity of processes involved during partial melting at a scale ranging from a few microns to centimeters. This study confirms and shows that partially melted rocks are open systems in which changes in P-T conditions, deformation and mass transfer, that we have defined as meltdriven metasomatism, are preserved in the mineralogical assemblage and the major and trace element distribution revealed by X-ray microprobe and LA-ICPMS mapping respectively. One of the main challenges is to be able to distinguish the mineralogical records of a process like metasomatism from those related to changes in P-T conditions.

A first key observation and interpretation is that melt segregation and extraction coupled with changes in P-T conditions (due to decompression in this example) induce local disequilibrium between the segregated melt and the residual host-rock. The establishment of chemical potential gradients at the interface of these two sub-systems drives diffusive mass transfer. Our thermodynamic modeling shows that while $\mathrm{H}_{2} \mathrm{O}, \mathrm{Na}_{2} \mathrm{O}, \mathrm{CaO}$ and $\mathrm{K}_{2} \mathrm{O}$ are transferred from the melt to the host rock, $\mathrm{SiO}_{2}$ diffuses in the opposite direction. This combined mass transfer results in the formation of a quartz-rich and almost anhydrous leucosome and a quartzundersaturated selvage at the expense of the host-granulite. Depending on the initial bulk-rock composition, P-T conditions of melt extraction and shape of the P-T path, the element that will diffusive (or not) in or out the melt domain and the residue will vary. We suggest that the variety of mineralogical compositions encountered in selvages surrounding leucosomes in migmatites 
relates directly to these environmental variables and the induced melt-driven metasomatism.

Garnets show a complex major and trace element distribution that varies consistently with the petrographic setting. We suggest that preserved chemical zoning reflects the superposition of changes in P-T conditions and melt-driven metasomatism. Major and trace element zoning was first acquired during prograde and peak metamorphism garnet growth in a temperature range of 675 and $790^{\circ} \mathrm{C}$. Garnet grew mostly as a peritectic phase during biotite-dehydration melting reaction. Calcium, Y and HREEs (from Lu to Dy), are characterized by a bell-shape distribution and LREEs (from La to Gd) show a bowl-shape. The chemical zoning is consistent with a typical Rayleigh fractionation model with fast intergranular element mobility of all elements, including REEs, and rock-wide equilibration. The fast mobility is enhanced by the presence of melt along grain boundaries.

The post-peak melt-driven metasomatism event is responsible for the modification of the prograde zoning growth. Both Calcium and REE's are susceptible to the post-growth alteration and results in a complete or partial re-equilibration through diffusion of garnet composition at the P-T-X conditions of metasomatism $\left(0.8\right.$ to $\left.0.5 \mathrm{GPa} ; 790^{\circ} \mathrm{C}\right)$. Garnet cores in contact with polyphased inclusions were affected by the post-growth modification due to the presence of a network of open channels and cracks that act as connecting pathways between the matrix and garnet core. Once again, at these high temperature conditions and in the presence of melt (and fluid), divalent cation $\left(\mathrm{Ca}^{2+}\right)$ and REE are characterized by fast inter-granular and intragranular element mobility and rock-wide equilibration. We conclude that in this peculiar case (high temperature and melt/fluid-bearing open system), REE are not less vulnerable to diffusive resetting than divalent cations.

Besides the interpretations regarding the formation of the quartz-undersaturated selvage and the mobility of major and trace elements at high temperature conditions, this contribution shows that an inaccurate interpretation of chemical zoning in garnet could result in misleading thermobarometric results. Indeed, if the modified garnet core compositions (i.e. low calcium content) were used as the chemical fingerprint of the early garnet nucleation stage it would 35 
919 have resulted in erroneous low-pressure condition estimates for garnet nucleation.

\section{ACKNOWLEDGEMENTS}

923 This work was partially supported by the program CAPES-COFECUB $n^{\circ} 624 / 09$. We greatly 924 acknowledge Johildo Barabosa and Hervé Martin, the main investigators of the program. We 925 thank Johildo Barbosa for introducing the Farol da Barra outcrop and for the fruitful discussions. 926 The structural analysis is part of the PhD dissertation of JSS funded by the program CAPES-

Ague, J. J. (2017). Element mobility during regional metamorphism in crustal and subduction zone environments with a focus on the rare earth elements (REE). American Mineralogist, 102(9), 1796-1821. https://doi.org/10.2138/am-2017-6130

Alessio, K. L., Hand, M., Morrissey, L. J., Kelsey, D. E., \& Payne, J. L. (2017). Melt Reintegration Modelling: Testing against a Subsolidus Reference Assemblage. Geosciences, 7(3), 75. https://doi.org/10.3390/geosciences7030075

Ashworth, J. R., \& McLellan, E. L. (1985). Textures. In J. R. Ashworth (Éd.), Migmatites (p. 180-203). Springer US. https://doi.org/10.1007/978-1-4613-2347-1_5 
Barbosa, J. S. F., \& Sabaté, P. (2004). Archean and Paleoproterozoic crust of the São Francisco Craton, Bahia, Brazil: Geodynamic features. Precambrian Research, 133(1), 1-27. https://doi.org/10.1016/j.precamres.2004.03.001

Bartoli, O. (2017). Phase equilibria modelling of residual migmatites and granulites: An evaluation of the melt-reintegration approach. Journal of Metamorphic Geology, 35(8), 919-942. https://doi.org/10.1111/jmg.12261

Beaumont, C., Jamieson, R. A., Nguyen, M. H., \& Medvedev, S. (2004). Crustal channel flows: 1. Numerical models with applications to the tectonics of the Himalayan-Tibetan orogen. Journal of Geophysical Research: Solid Earth, 109(B6), B06406. https: / /doi.org/10.1029/2003JB002809

Brown, M. (2010). Melting of the continental crust during orogenesis: The thermal, rheological, and compositional consequences of melt transport from lower to upper continental crust. Canadian Journal of Earth Sciences, 47(5), 655-694. https://doi.org/10.1139/E09-057

Caddick, M. J., Konopásek, J., \& Thompson, A. B. (2010). Preservation of Garnet Growth Zoning and the Duration of Prograde Metamorphism. Journal of Petrology, 51(11), 2327-2347. https: / /doi.org/10.1093/petrology/egq059

Carlson, W. D. (2006). Rates of Fe, Mg, Mn, and Ca diffusion in garnet. American Mineralogist, 91(1), 1-11. https://doi.org/10.2138/am.2006.2043

Carlson, W. D. (2012). Rates and mechanism of Y, REE, and Cr diffusion in garnet. American Mineralogist, 97(10), 1598-1618. https://doi.org/10.2138/am.2012.4108

Clemens, J. D. (1984). Water contents of silicic to intermediate magmas. Lithos, 17, 273-287. https://doi.org/10.1016/0024-4937(84)90025-2

Connolly, J. A. D. (2005). Computation of phase equilibria by linear programming: A tool for geodynamic modeling and its application to subduction zone decarbonation. Earth and Planetary Science Letters, 236(1-2), 524-541. https://doi.org/10.1016/j.epsl.2005.04.033

Da Silva, L. C., McNaughton, N. J., Melo, R. C., \& Fletcher, I. R. (1997). U-Pb SHRIMP ages in the Itabuna-Caraíba TTG high-grade complex: The first window beyond the Paleoproterozoic overprinting of the eastern Jequié craton, NE Brazil. ResearchGate, 282. 
https://www.researchgate.net/publication/284106273_U-

Pb_SHRIMP_ages_in_the_Itabuna-Caraiba_TTG_high-

grade_complex_The_first_window_beyond_the_Paleoproterozoic_overprinting_of_the_east ern_Jequie_craton_NE_Brazil

Dumond, G., Goncalves, P., Williams, M. L., \& Jercinovic, M. J. (2015). Monazite as a monitor of melting, garnet growth and feldspar recrystallization in continental lower crust. Journal of Metamorphic Geology, 33(7), 735-762. https://doi.org/10.1111/jmg.12150

Dunkley, D. J., Clarke, G. L., \& Harley, S. L. (1999). Diffusion metasomatism in silicaundersaturated sapphirine-bearing granulite from Rumdoodle Peak, Framnes Mountains, east Antarctica. Contributions to Mineralogy and Petrology, 134(2), 264-276. https://doi.org/10.1007/s004100050483

Etheridge, M. A., Daczko, N. R., Chapman, T., \& Stuart, C. A. (2020). Mechanisms of melt extraction during lower crustal partial melting. Journal of Metamorphic Geology, . https://doi.org/10.1111/jmg.12561

Fitzsimons, I. C. W. (1996). Metapelitic Migmatites from Brattstrand Bluffs, East AntarcticaMetamorphism, Melting and Exhumation of the Mid Crust. Journal of Petrology, 37(2), 395-414. https://doi.org/10.1093/petrology/37.2.395

Fujimori, S. (1988). Condições de P-T de formação dos granulitos do Farol da Barra, Salvador, Bahia, Brasil. Revista Brasileira de Geociências, 18(3), 339-344.

Gaidies, F., Morneau, Y. E., Petts, D. C., Jackson, S. E., Zagorevski, A., \& Ryan, J. J. (s. d.). Major and trace element mapping of garnet: Unravelling the conditions, timing and rates of metamorphism of the Snowcap assemblage, west-central Yukon. Journal of Metamorphic Geology, n/a(n/a). https://doi.org/10.1111/jmg.12562

George, F. R., \& Gaidies, F. (2017). Characterisation of a garnet population from the Sikkim Himalaya: Insights into the rates and mechanisms of porphyroblast crystallisation. Contributions to Mineralogy and Petrology, 172(7), 57. https://doi.org/10.1007/s00410017-1372-y

George, F. R., Gaidies, F., \& Boucher, B. (2018). Population-wide garnet growth zoning revealed 38 
by LA-ICP-MS mapping: Implications for trace element equilibration and syn-kinematic deformation during crystallisation. Contributions to Mineralogy and Petrology, 173(9), 74. https://doi.org/10.1007/s00410-018-1503-0

Grant, J. A. (1985). Phase equilibria in partial melting of pelitic rocks. In Migmatites (p. 86-144). Springer, Boston, MA. https://doi.org/10.1007/978-1-4613-2347-1_3

Guernina, S., \& Sawyer, E. W. (2003). Large-scale melt-depletion in granulite terranes : An example from the Archean Ashuanipi Subprovince of Quebec. Journal of Metamorphic Geology, 21(2), 181-201. https://doi.org/10.1046/j.1525-1314.2003.00436.x

Hasalová, P., Schulmann, K., Lexa, O., Štípská, P., Hrouda, F., Ulrich, S., Haloda, J., \& Týcová, P. (2008). Origin of migmatites by deformation-enhanced melt infiltration of orthogneiss : A new model based on quantitative microstructural analysis. Journal of Metamorphic Geology, 26(1), 29-53. https://doi.org/10.1111/j.1525-1314.2007.00743.x

Hermann, J., \& Rubatto, D. (2003). Relating zircon and monazite domains to garnet growth zones: Age and duration of granulite facies metamorphism in the Val Malenco lower crust. Journal of Metamorphic Geology, 21(9), 833-852. https://doi.org/10.1046/j.15251314.2003.00484.x

Holland, T. J. B., \& Powell, R. (1998). An internally consistent thermodynamic data set for phases of petrological interest. Journal of Metamorphic Geology, 16(3), 309-343. https://doi.org/10.1111/j.1525-1314.1998.00140.x

Holland, T., \& Powell, R. (2001). Calculation of Phase Relations Involving Haplogranitic Melts Using an Internally Consistent Thermodynamic Dataset. Journal of Petrology, 42(4), 673-683. https://doi.org/10.1093/petrology/42.4.673

Hollister, L. S., \& Crawford, M. L. (1986). Melt-enhanced deformation : A major tectonic process. Geology, 14(7), 558-561. https://doi.org/10.1130/00917613(1986)14<558:MDAMTP>2.0.CO;2

Holness, M. B., \& Sawyer, E. W. (2008). On the Pseudomorphing of Melt-filled Pores During the Crystallization of Migmatites. Journal of Petrology, 49(7), 1343-1363. https: / /doi.org/10.1093/petrology/egn028 
Hurai, V., Paquette, J.-L., Huraiová, M., \& Konečný, P. (2010). U-Th-Pb geochronology of zircon and monazite from syenite and pincinite xenoliths in Pliocene alkali basalts of the intraCarpathian back-arc basin. Journal of Volcanology and Geothermal Research, 198(3), 275-287. https://doi.org/10.1016/j.jvolgeores.2010.09.012

Hyppolito, T., Cambeses, A., Angiboust, S., Raimondo, T., García-Casco, A., \& Juliani, C. (2019). Rehydration of eclogites and garnet-replacement processes during exhumation in the amphibolite facies. Geological Society, London, Special Publications, 478(1), 217-239. https://doi.org/10.1144/SP478.3

Jamieson, R. A., Unsworth, M. J., Harris, N. B. W., Rosenberg, C. L., \& Schulmann, K. (2011). Crustal Melting and the Flow of Mountains. Elements, 7(4), 253-260. https://doi.org/10.2113/gselements.7.4.253

Konrad-Schmolke, M., O’Brien, P. J., de Capitani, C., \& Carswell, D. A. (2008). Garnet growth at high- and ultra-high pressure conditions and the effect of element fractionation on mineral modes and composition. Lithos, 103(3), 309-332. https://doi.org/10.1016/j.lithos.2007.10.007

Konrad-Schmolke, M., Zack, T., O’Brien, P. J., \& Jacob, D. E. (2008). Combined thermodynamic and rare earth element modelling of garnet growth during subduction : Examples from ultrahigh-pressure eclogite of the Western Gneiss Region, Norway. Earth and Planetary Science Letters, 272(1-2), 488-498. https://doi.org/10.1016/j.epsl.2008.05.018

Kriegsman, L. M., \& Hensen, B. J. (1998). Back reaction between restite and melt: Implications for geothermobarometry and pressure-temperature paths. Geology, 26(12), 1111-1114. https://doi.org/10.1130/0091-7613(1998)026<1111:BRBRAM>2.3.CO;2

Le Breton, N. (1988). Fluid-absent (dehydration) melting of biotite in metapelites in the early stages of crustal anatexis. Contributions to Mineralogy and Petrology, 99(2), 226-237. https://doi.org/10.1007/BF00371463

Lin, L., \& Sawyer, E. W. (2019). Microstructure and compositional changes across biotite-rich reaction selvedges around mafic schollen in a semipelitic diatexite migmatite. Journal of Metamorphic Geology, 37(4), 539-566. https://doi.org/10.1111/jmg.12475 
Mahan, K. H., Goncalves, P., Williams, M. L., \& Jercinovic, M. J. (2006). Dating metamorphic reactions and fluid flow: Application to exhumation of high-P granulites in a crustal-scale shear zone, western Canadian Shield. Journal of Metamorphic Geology, 24(3), 193-217. https://doi.org/10.1111/j.1525-1314.2006.00633.x

Migdisov, Art. A., Williams-Jones, A. E., \& Wagner, T. (2009). An experimental study of the solubility and speciation of the Rare Earth Elements (III) in fluoride- and chloride-bearing aqueous solutions at temperatures up to $300^{\circ} \mathrm{C}$. Geochimica et Cosmochimica Acta, 73(23), 7087-7109. https://doi.org/10.1016/j.gca.2009.08.023

Moore, S. J., Carlson, W. D., \& Hesse, M. A. (2013). Origins of yttrium and rare earth element distributions in metamorphic garnet. Journal of Metamorphic Geology, 31(6), 663-689. https://doi.org/10.1111/jmg.12039

Olsen, S. N., \& Grant, J. A. (1991). Isocon analysis of migmatization in the Front Range, Colorado, USA. Journal of Metamorphic Geology, 9(2), 151-164. https://doi.org/10.1111/j.1525-1314.1991.tb00511.x

Otamendi, J. E., Rosa, J. D. de la, Douce, A. E. P., \& Castro, A. (2002). Rayleigh fractionation of heavy rare earths and yttrium during metamorphic garnet growth. Geology, 30(2), 159-162. https://doi.org/10.1130/0091-7613(2002)030<0159:RFOHRE>2.0.CO;2

Owen, J. V. (1991). Cordierite + spinel parageneses in pelitic gneiss from the contact aureoles of the Mistastin batholith (Quebec) and the Taylor Brook gabbro complex (Newfoundland). Canadian Journal of Earth Sciences, 28(3), 372-381. https://doi.org/10.1139/e91-034

Paquette, J.-L., Piro, J.-L., Devidal, J.-L., Bosse, V., Didier, A., Sannac, S., \& Abdelnour, Y. (2014). Sensitivity Enhancement in LA-ICP-MS by N2 Addition to Carrier Gas: Application to Radiometric Dating of U-Th-Bearing Minerals. Agilent ICP-MS Journal, 58, 4-5.

Penniston-Dorland, S. C., \& Ferry, J. M. (2008). Element mobility and scale of mass transport in the formation of quartz veins during regional metamorphism of the Waits River Formation, east-central Vermont. American Mineralogist, 93(1), 7-21. https://doi.org/10.2138/am.2008.2461

Piazolo, S., Daczko, N. R., Silva, D., \& Raimondo, T. (2020). Melt-present shear zones enable 41 
intracontinental orogenesis. Geology, 48. https://doi.org/10.1130/G47126.1

Prent, A. M., Beinlich, A., Morrissey, L. J., Raimondo, T., Clark, C., \& Putnis, A. (2019). Monazite as a monitor for melt-rock interaction during cooling and exhumation. Journal of Metamorphic Geology, 37(3), 415-438. https://doi.org/10.1111/jmg.12471

Pyle, J. M., \& Spear, F. S. (2003). Yttrium zoning in garnet: Coupling of major and accessory phases during metamorphic reactions. American Mineralogist, 88(4), 708-708.

Pyle, J., \& Spear, F. (2003). Four generations of accessory-phase growth in low-pressure migmatites from SW New Hampshire. American Mineralogist, 88, 338-351. https://doi.org/10.2138/am-2003-2-311

Rabin, M., Trap, P., Carry, N., Fréville, K., Cenki-Tok, B., Lobjoie, C., Goncalves, P., \& Marquer, D. (2015). Strain partitioning along the anatectic front in the Variscan Montagne Noire massif (southern French Massif Central). Tectonics, 34(8), 1709-1735. https://doi.org/10.1002/2014TC003790

Raimondo, T., Payne, J., Wade, B., Lanari, P., Clark, C., \& Hand, M. (2017). Trace element mapping by LA-ICP-MS : Assessing geochemical mobility in garnet. Contributions to Mineralogy and Petrology, 172(4), 17. https://doi.org/10.1007/s00410-017-1339-z

Rosenberg, C. L., \& Handy, M. R. (2005). Experimental deformation of partially melted granite revisited: Implications for the continental crust. Journal of Metamorphic Geology, 23(1), 19-28. https://doi.org/10.1111/j.1525-1314.2005.00555.x

Rubatto, D., Burger, M., Lanari, P., Hattendorf, B., Schwarz, G., Neff, C., Keresztes Schmidt, P., Hermann, J., Vho, A., \& Günther, D. (2020). Identification of growth mechanisms in metamorphic garnet by high-resolution trace element mapping with LA-ICP-TOFMS. Contributions to Mineralogy and Petrology, 175(7), 61. https://doi.org/10.1007/s00410$\underline{020-01700-5}$

Royden, L. H., Burchfiel, B. C., King, R. W., Wang, E., Chen, Z., Shen, F., \& Liu, Y. (1997). Surface Deformation and Lower Crustal Flow in Eastern Tibet. Science, 276(5313), 788-790. https://doi.org/10.1126/science.276.5313.788

Sawyer, E. W. (2001). Melt segregation in the continental crust : Distribution and movement of 42 
melt in anatectic rocks. Journal of Metamorphic Geology, 19(3), 291-309.

https://doi.org/10.1046/j.0263-4929.2000.00312.x

Skora, S., Baumgartner, L. P., Mahlen, N. J., Johnson, C. M., Pilet, S., \& Hellebrand, E. (2006). Diffusion-limited REE uptake by eclogite garnets and its consequences for Lu-Hf and Sm-Nd geochronology. Contributions to Mineralogy and Petrology, 152(6), 703-720. https://doi.org/10.1007/s00410-006-0128-x

Souza, J. S. de, Barbosa, J. S. F., \& Gomes, L. C. C. (2010). Litogeoquímica dos granulitos ortoderivados da cidade de Salvador, Bahia. Revista Brasileira de Geociências, 40(3), $339-354$.

Souza-Oliveira, J. S. de, Peucat, J.-J., Barbosa, J. S. F., Correa-Gomes, L. C., Cruz, S. C. P., Leal, Â. B. M., \& Paquette, J.-L. (2014). Lithogeochemistry and geochronology of the subalkaline felsic plutonism that marks the end of the Paleoproterozoic orogeny in the Salvador-Esplanada belt, São Francisco craton (Salvador, state of Bahia, Brazil). Brazilian Journal of Geology, 44(2), 221-234. https://doi.org/10.5327/Z2317-4889201400020004

Spear, F. S., Kohn, M. J., \& Cheney, J. T. (1999). <Emphasis Type="Italic">P </Emphasis >$<$ Emphasis Type="Italic">T</Emphasis $>$ paths from anatectic pelites. Contributions to Mineralogy and Petrology, 134(1), 17-32. https://doi.org/10.1007/s004100050466

Stuart, C. A., Piazolo, S., \& Daczko, N. R. (2018). The recognition of former melt flux through high-strain zones. Journal of Metamorphic Geology, 36(8), 1049-1069. https://doi.org/10.1111/jmg.12427

Thompson, A. B. (1982). Dehydration melting of pelitic rocks and the generation of $\mathrm{H} 2 \mathrm{O}$ undersaturated granitic liquids. American Journal of Science, 282(10), 1567-1595. https://doi.org/10.2475/ajs.282.10.1567

Tomkins, H. S., \& Pattison, D. R. M. (2007). Accessory phase petrogenesis in relation to major phase assemblages in pelites from the Nelson contact aureole, southern British Columbia. Journal of Metamorphic Geology, 25(4), 401-421. https://doi.org/10.1111/j.15251314.2007.00702.x

Ubide, T., McKenna, C. A., Chew, D. M., \& Kamber, B. S. (2015). High-resolution LA-ICP-MS trace 43 
element mapping of igneous minerals : In search of magma histories. Chemical Geology, 409, 157-168. https://doi.org/10.1016/j.chemgeo.2015.05.020

Vanderhaeghe, O. (2012). The thermal-mechanical evolution of crustal orogenic belts at convergent plate boundaries: A reappraisal of the orogenic cycle. Journal of Geodynamics, 56-57, 124-145. https://doi.org/10.1016/j.jog.2011.10.004

Vernon, R. H. (2011). Microstructures of melt-bearing regional metamorphic rocks. In D. D. van Reenen, J. D. Kramers, S. McCourt, \& L. L. Perchuk, Origin and Evolution of Precambrian High-Grade Gneiss Terranes, with Special Emphasis on the Limpopo Complex of Southern Africa. Geological Society of America. https://doi.org/10.1130/2011.1207(01)

Vielzeuf, D., \& Schmidt, M. (2001). Melting relations in hydrous systems revisited: Application to metapelites, metagreywackes and metabasalts. Contributions to Mineralogy and Petrology, 141, 251-267. https://doi.org/10.1007/s004100100237

Vielzeuf, Daniel, \& Holloway, J. R. (1988). Experimental determination of the fluid-absent melting relations in the pelitic system. Contributions to Mineralogy and Petrology, 98(3), 257-276. https://doi.org/10.1007/BF00375178

Vielzeuf, Daniel, \& Montel, J. M. (1994). Partial melting of metagreywackes. Part I. Fluid-absent experiments and phase relationships. Contributions to Mineralogy and Petrology, 117(4), 375-393. https://doi.org/10.1007/BF00307272

Warren, C. J., Greenwood, L. V., Argles, T. W., Roberts, N. M. W., Parrish, R. R., \& Harris, N. B. W. (2019). Garnet-monazite rare earth element relationships in sub-solidus metapelites : A case study from Bhutan. Geological Society, London, Special Publications, 478(1), 145-166. https://doi.org/10.1144/SP478.1

Weller, O. M., Jackson, S., Miller, W. G. R., St-Onge, M. R., \& Rayner, N. (2020). Quantitative elemental mapping of granulite-facies monazite: Textural insights and implications for petrochronology. Journal of Metamorphic Geology, 38(8), 853-880.

https://doi.org/10.1111/jmg.12552

White, R. W., \& Powell, R. (2010). Retrograde melt-residue interaction and the formation of near-anhydrous leucosomes in migmatites. Journal of Metamorphic Geology, 28(6), 
579-597. https://doi.org/10.1111/j.1525-1314.2010.00881.x

White, R. W., Powell, R., \& Holland, T. J. B. (2001). Calculation of partial melting equilibria in the system Na2O-CaO-K2O-FeO-MgO-Al2O3-SiO2-H2O (NCKFMASH). Journal of Metamorphic Geology, 19(2), 139-153. https://doi.org/10.1046/j.0263-4929.2000.00303.x

Williams-Jones, A. E., Migdisov, A. A., \& Samson, I. M. (2012). Hydrothermal Mobilisation of the Rare Earth Elements - a Tale of “Ceria” and “Yttria”. Elements, 8(5), 355-360. https://doi.org/10.2113/gselements.8.5.355

Yakymchuk, C., \& Brown, M. (2014). Consequences of open-system melting in tectonics. Journal of the Geological Society, 171(1), 21-40. https://doi.org/10.1144/jgs2013-039

Yuguchi, T., \& Nishiyama, T. (2008). The mechanism of myrmekite formation deduced from steady-diffusion modeling based on petrography: Case study of the Okueyama granitic body, Kyushu, Japan. Lithos, 106(3), 237-260.

https://doi.org/10.1016/j.lithos.2008.07.017

937

938

\section{FIGURE CAPTIONS}

Figure 1. (a) Aerial photograph of the Farol da Barra outcrop in the city of Salvador da Bahia, with a corresponding structural and geological map (right-hand side). (b) Simplified structural cross section including the studied area, showing the finite strain pattern consisting of a gently dipping S1 fabric and steeply dipping D2 high strain zones. On both figures, the location of the studied sample 06SB06 is shown as a red star.

Figure 2. (a) Photograph of the studied outcrop showing the steeply dipping S2 gneissic foliation. The leucosome is surrounded by a melanocratic quartz-undersaturated selvage. (b) Polished slice 45 
of the studied sample 06SB06 showing the location of the three thin sections.
952

953

954

955

956

957

958

959

960

961

962

Figure 3. (a) Photomicrograph of the metamorphic assemblage in the quartz-saturated granulite. (b) Cordierite development at the contact between garnet and sillimanite in the quartzsaturated granulite. (c) Spinel and cordierite symplectite developed at the expense of garnet and sillimanite in the quartz-undersaturated selvage.

Figure 4. Thin-section scans under crossed-polarized light showing the location of the seven analyzed garnets (A to $G$ ). Garnets $A$ and $B$ are located in the quartz-undersaturated selvage. Notice the change in grain size and proportion of inclusions with increasing distance from the leucosome.

Figure 5. Photomicrographs of the seven analyzed garnets. (a) Garnet A; (b) Garnet B; (c) Garnet C; (d) Garnet D; (e) Garnet E; (f) Garnet F; (g) Garnet G. The size of the scale bar shown is 50 $\mu \mathrm{m}$ for all cases, and dashed lines correspond to the location of major element profiles shown in Figure 9.

Figure 6. Backscattered electron images of crystallized melt inclusions in the outer rim of Garnet B located in the quartz-undersaturated selvage. (a), garnet negative crystal shape crystallized melt inclusion; (b) polyphase xenomorph crystallized melt inclusion; and (c) radial crack attesting to melt inclusion decrepitation

Figure 7. (a) Backscattered electron image of a representative garnet in the quartz-saturated granulite. (b) 3D reconstruction from a computed X-ray microtomography of garnet. (c-f) sequential slices of the 3D reconstructed garnet (in red) showing the channels (white arrows) 
975 976

977 978

979 980

connecting the irregular inclusions (transparent) to the outside matrix.

Figure 8. (a) Cathodoluminescence images of K-feldspar texture (blue) with plagioclase films and pool (brown) along grain boundaries. Plagioclase films are connected to myrmekite pools (m). (b) Extensive replacement of K-feldspar by plagioclase and myrmekites.

Figure 9. Garnet composition (black square $=$ molar amount of grossular and white square $=$ $\mathrm{XMg}$ ). The location of each line profile is shown in figure 5 . The dark and light gray stripes correspond to plagioclase-quartz inclusions and domains with minute inclusions of quartz, respectively.

Figure 10. LA-ICP-MS trace element maps of (a) garnet A; (b) Garnet B; (c) Garnet G.

Concentrations values are in ppm. The line profiles shown in Figure 11-13 are located in each case on the Phosphorus (P) map.

Figure 11. LA-ICP-MS trace element line profile of Garnet A. . See Figure 10a for traverse location.

Figure 12. LA-ICP-MS trace element line profile of Garnet B. See Figure 10b for traverse location.

Figure 13. LA-ICP-MS trace element line profile of Garnet G. See Figure 10c for traverse location. 
999 Figure 14. P-T phase diagram section computed for with quartz-saturated granulite composition 1000 (see Table 1). Circles with letters indicate the P-T conditions corresponding to measured garnet 1001 compositions. The letters refer to garnet grain labels in Figure 5.

1003 Figure 15. Evolution of chemical potential of $\mathrm{H}_{2} \mathrm{O}, \mathrm{SiO}_{2}, \mathrm{CaO}$ and $\mathrm{K}_{2} \mathrm{O}$ for the quartz-saturated 1004 domain (black line) and melt (dashed line) along a decompression path from 0.8 to $0.5 \mathrm{GPa}$ at $1005790^{\circ} \mathrm{C}$.

Figure 16. $\mathrm{P}-\mathrm{X}$ phase diagram section computed at $790^{\circ} \mathrm{C}$ with $\mathrm{X}=0$ corresponding to the quartzsaturated domain and $\mathrm{X}=1$ corresponding to a $55 \%$ loss of $\mathrm{SiO}_{2}$ and $200 \%$ gain of $\mathrm{H}_{2} \mathrm{O}$. See Table 1 for compositions.

Figure 17. P-T phase diagram section computed with a modeled quartz-undersaturated selvage composition produced after a $47 \%$ loss of $\mathrm{SiO}_{2}$ and $140 \%$ gain of $\mathrm{H}_{2} \mathrm{O}$. See Table 1 for compositions.

Figure 18. (a) Full thin-section X-ray Al map of sample 06SB06a showing the petrographic setting of dated monazites. (b) Y map of monazite included in garnet and plagioclase. (c) Y map of monazite in the cordierite-bearing matrix. Note the presence of thin Y-rich overgrowths.

Figure 19. (a) Monazite U-Th-Pb concordia diagram. (b) Monazite Th-Pb ages. (c) Zircon U-Pb concordia diagram

\section{TABLE CAPTIONS}


1023 Table 1. Bulk geochemical compositions used in phase diagrams shown in figures 14-17

1024

1025

DATASETS AND SUPPORTING INFORMATION

1026

Figure S1. Simplified geological map of the São Francisco Craton modified after Barbosa et al.

1027 (2003).

1028

1029

Figure S2. (a) Simplified structural map of the southwestern part of the city of Salvador da

1030

Bahia. (b) Simplified structural cross-section. (c) Equal-area Schmidt lower hemisphere

1031

projection of poles to $S_{1}$ and $S_{2}$ foliations (dashed lines = conjugated shear zones associated the

1032

$\mathrm{S}_{2}$ mylonitic foliation).

1033

Figure S3. (a) Backscattered image of a polyphased plagioclase and quartz inclusion in a garnet.

(b) anorthite vs albite content in mole of plagioclase. Grey and black diamonds are plagioclase

composition in contact with quartz and garnet respectively. (c) Profile showing the evolution of plagioclase composition in contact with quartz and garnet. See location of the profile in figure a.

Figure S4. LA-ICP-MS Zr line profile of garnet A, B and G

Movie S1. 3D reconstruction from computed X-ray microtomography of garnet (see Figure 7). 
1048 Table S1. Solid solution models used in Figures 14-17

1049

1050 Dataset S1. Electron microprobe analysis of biotite, plagioclase, spinel and garnet. Garnet

1051 compositions include the seven profiles collected from Garnets A-G in Figure 9 (see Figure 5 for 1052 the line profile locations).

1054 Dataset S2. LA-ICP-MS trace element data of line profiles collected from Garnets A, B and G (see 1055 Figures 11-13).

1057 Dataset S3. Raw LA-ICPMS trace element data of garnet A (see map in Figure 10a)

1059 Dataset S4. Raw LA-ICPMS trace element data of garnet B (see map in Figure 10b) 1060

1061 Dataset S5. Raw LA-ICPMS trace element data of garnet A (see map in Figure 10c)

1063 Dataset S6. LA-ICP-MS isotopic U-Th-Pb data of monazite and zircon 

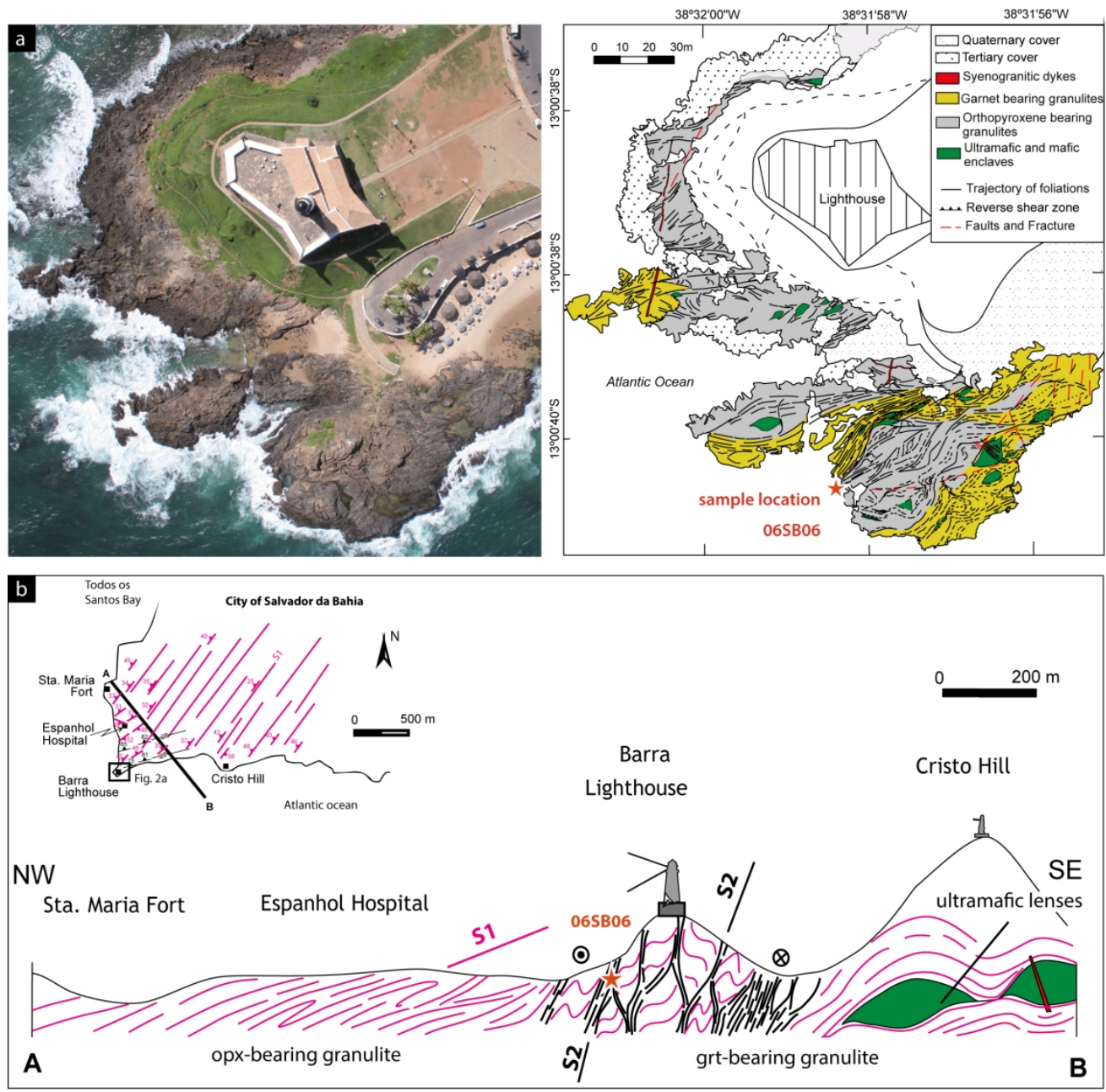

Figure 1

igure 1. (a) Aerial photograph of the Farol da Barra outcrop in the city of Salvador da Bahia, with a corresponding structural and geological map (right-hand side). (b) Simplified structural cross section including the studied area

$180 \times 188 \mathrm{~mm}(300 \times 300 \mathrm{DPI})$ 


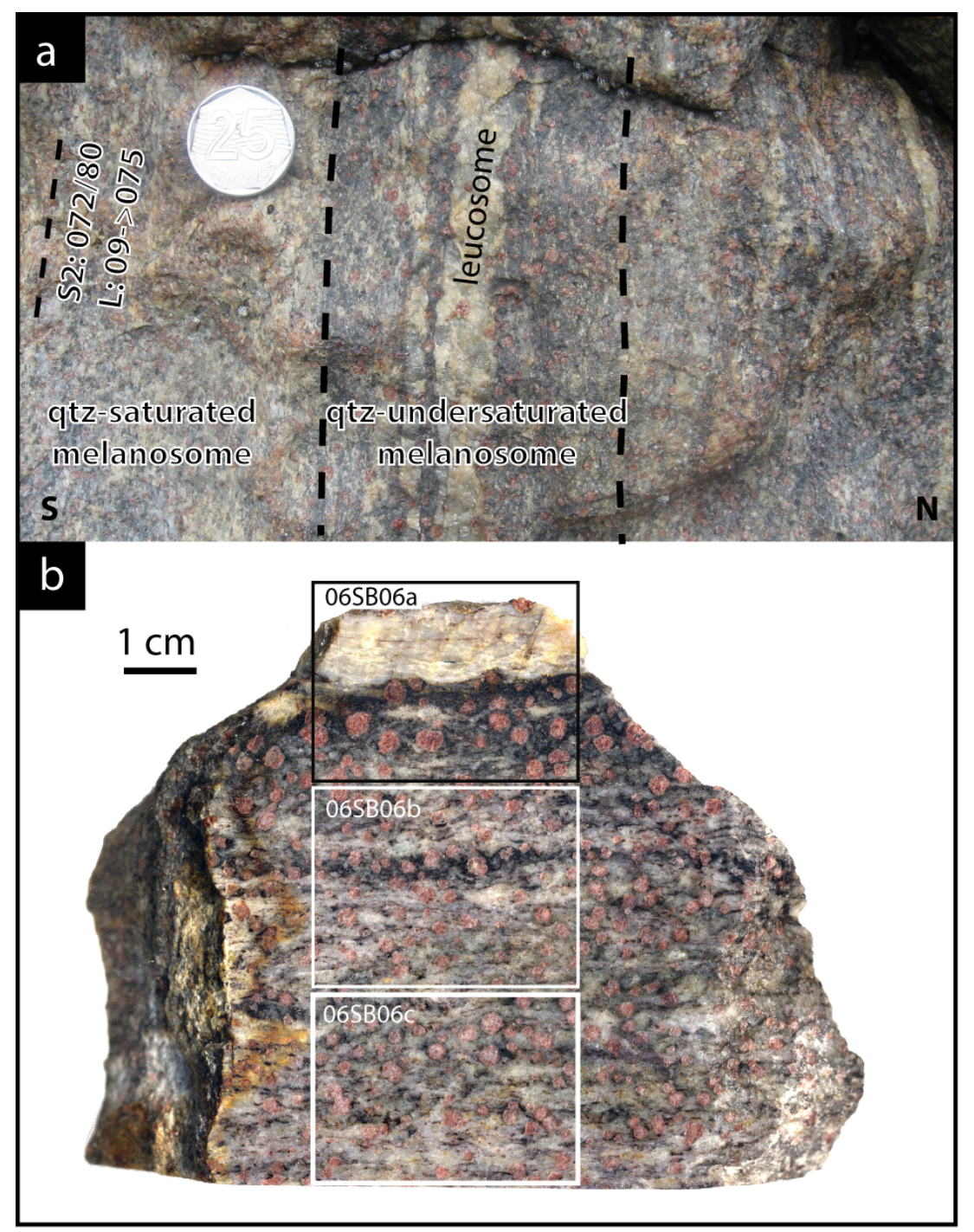

\section{figure 2}

Figure 2. (a) Photograph of the studied outcrop showing the steeply dipping S2 gneissic foliation. The leucosome is surrounded by a melanocratic quartz-undersaturated selvage. (b) Polished slice of the studied sample 06SB06 showing the location of the three thin sections.

$$
80 \times 115 \mathrm{~mm}(300 \times 300 \mathrm{DPI})
$$




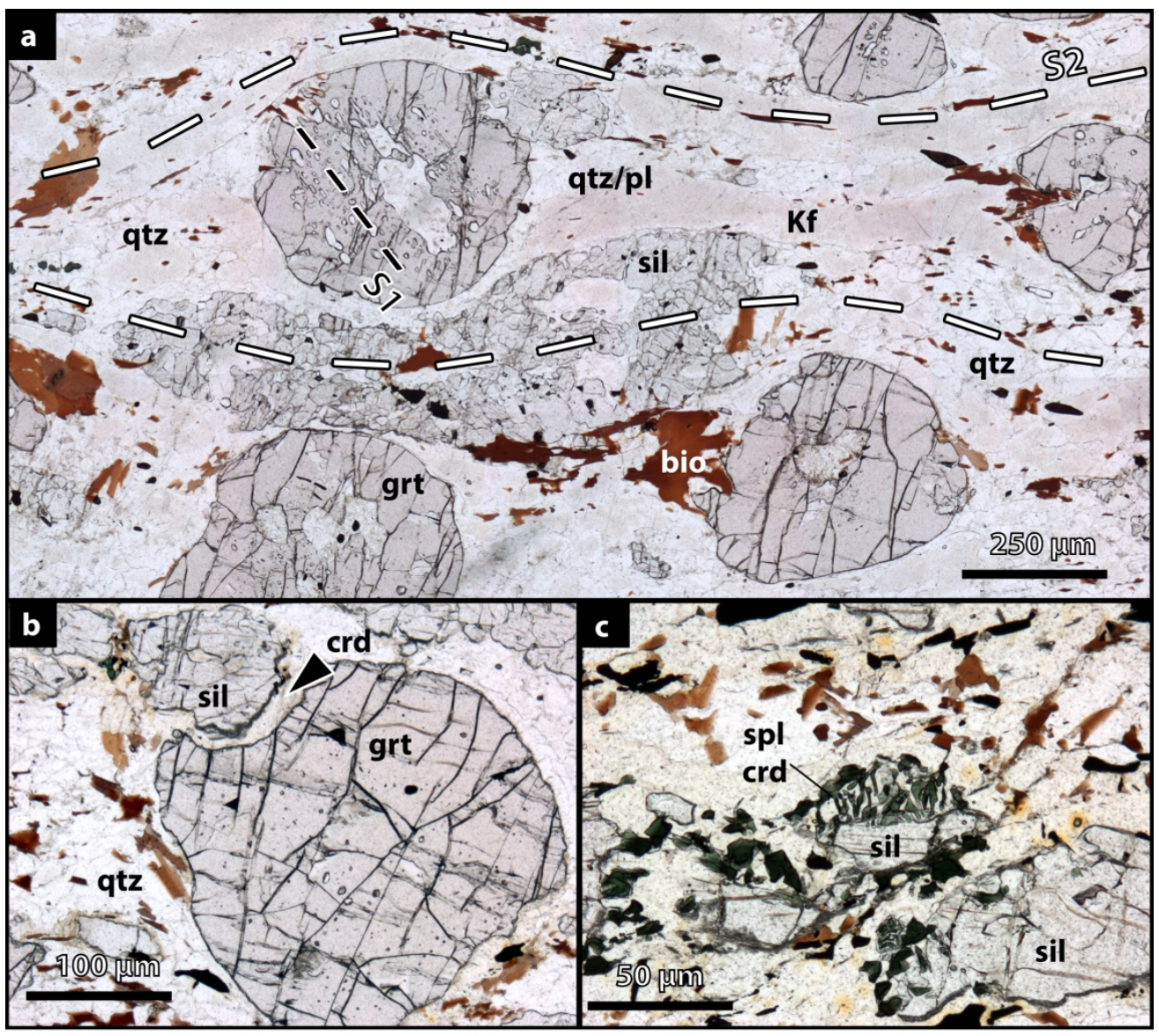

Figure 3

Figure 3. (a) Photomicrograph of the metamorphic assemblage in the quartz-saturated granulite. (b) Cordierite development at the contact between garnet and sillimanite in the quartz-saturated granulite. (c) Spinel and cordierite symplectite developed at the expense of garnet and sillimanite in the quartzundersaturated selvage. 

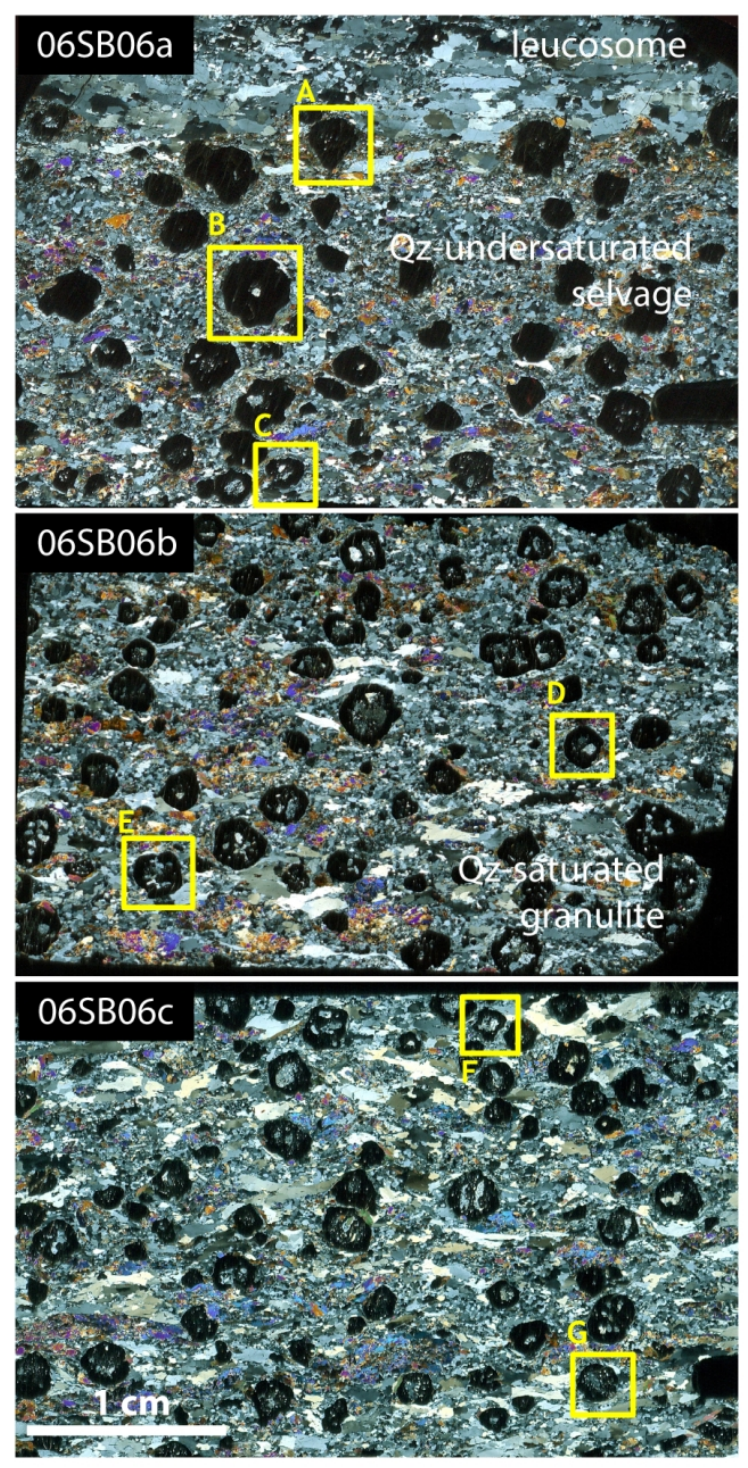

Figure 4

Figure 4. Thin-section scans under crossed-polarized light showing the location of the seven analyzed garnets (A to $G$ ).

$85 \times 160 \mathrm{~mm}(300 \times 300 \mathrm{DPI})$ 
quartz-undersaturated selvage

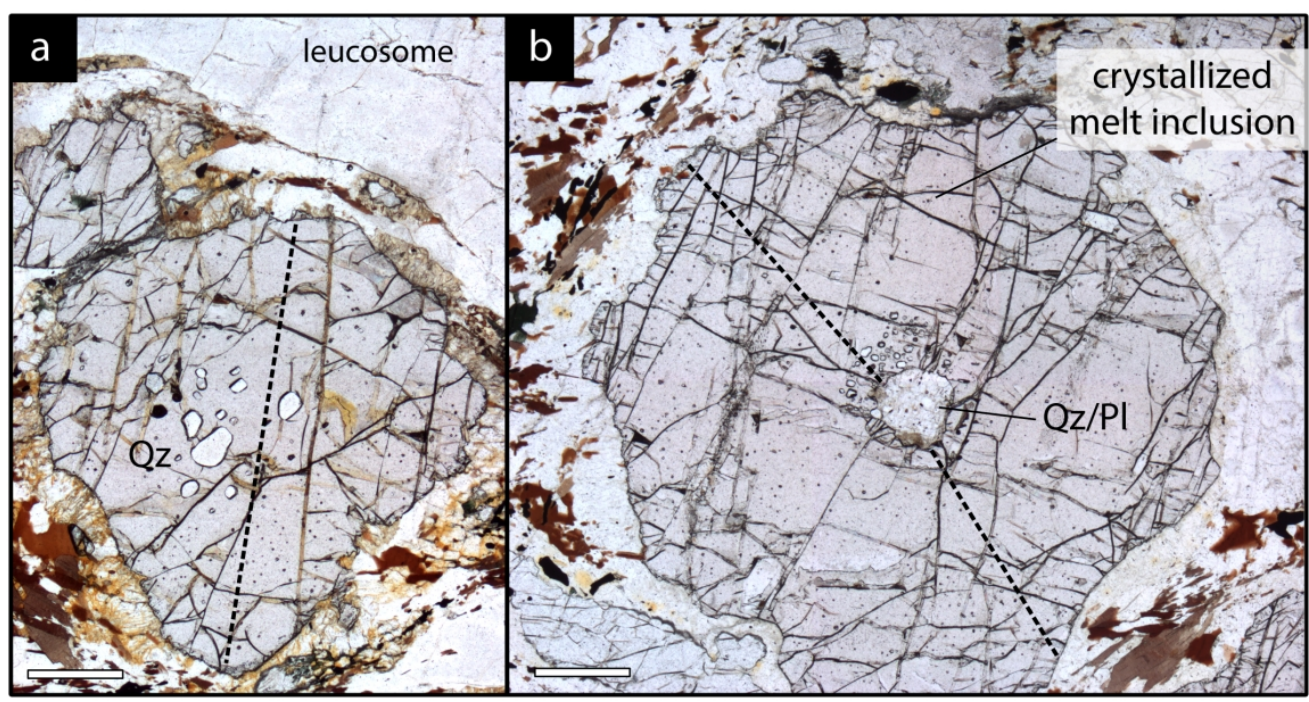

quartz-saturated domain

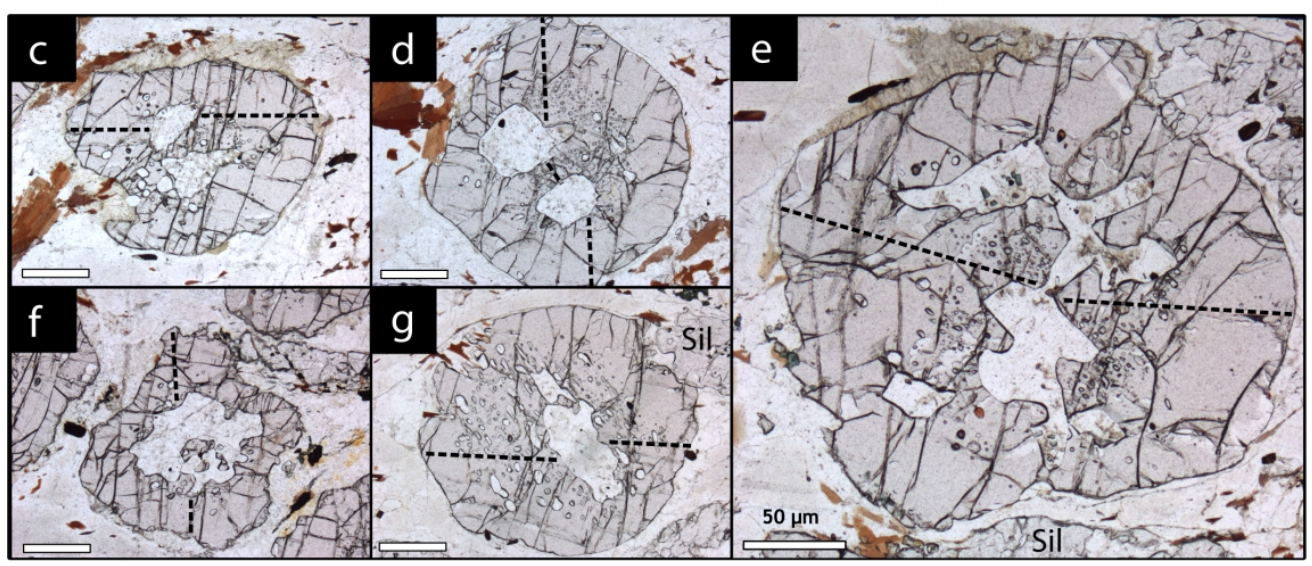

Figure 5

Figure 5. Photomicrographs of the seven analyzed garnets. (a) Garnet A; (b) Garnet B; (c) Garnet C; (d) Garnet D; (e) Garnet E; (f) Garnet F; (g) Garnet G. The size of the scale bar shown is $50 \mu \mathrm{m}$ for all cases, and dashed lines correspond to the location of major element profiles shown in Figure 9. 

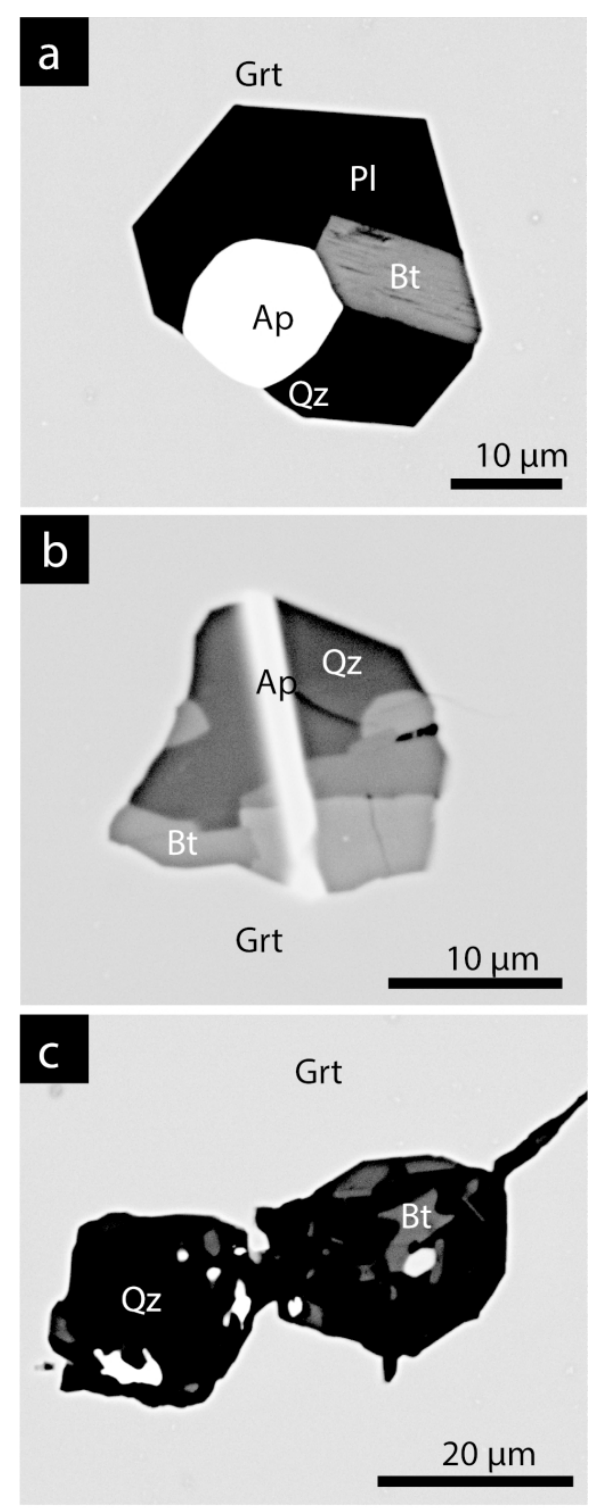

Figure 6

Figure 6. Backscattered electron images of crystallized melt inclusions in the outer rim of Garnet B located in the quartz-undersaturated selvage. (a), garnet negative crystal shape crystallized melt inclusion; (b) polyphase xenomorph crystallized melt inclusion; and (c) radial crack attesting to melt inclusion decrepitation

$80 \times 220 \mathrm{~mm}(300 \times 300$ DPI $)$ 


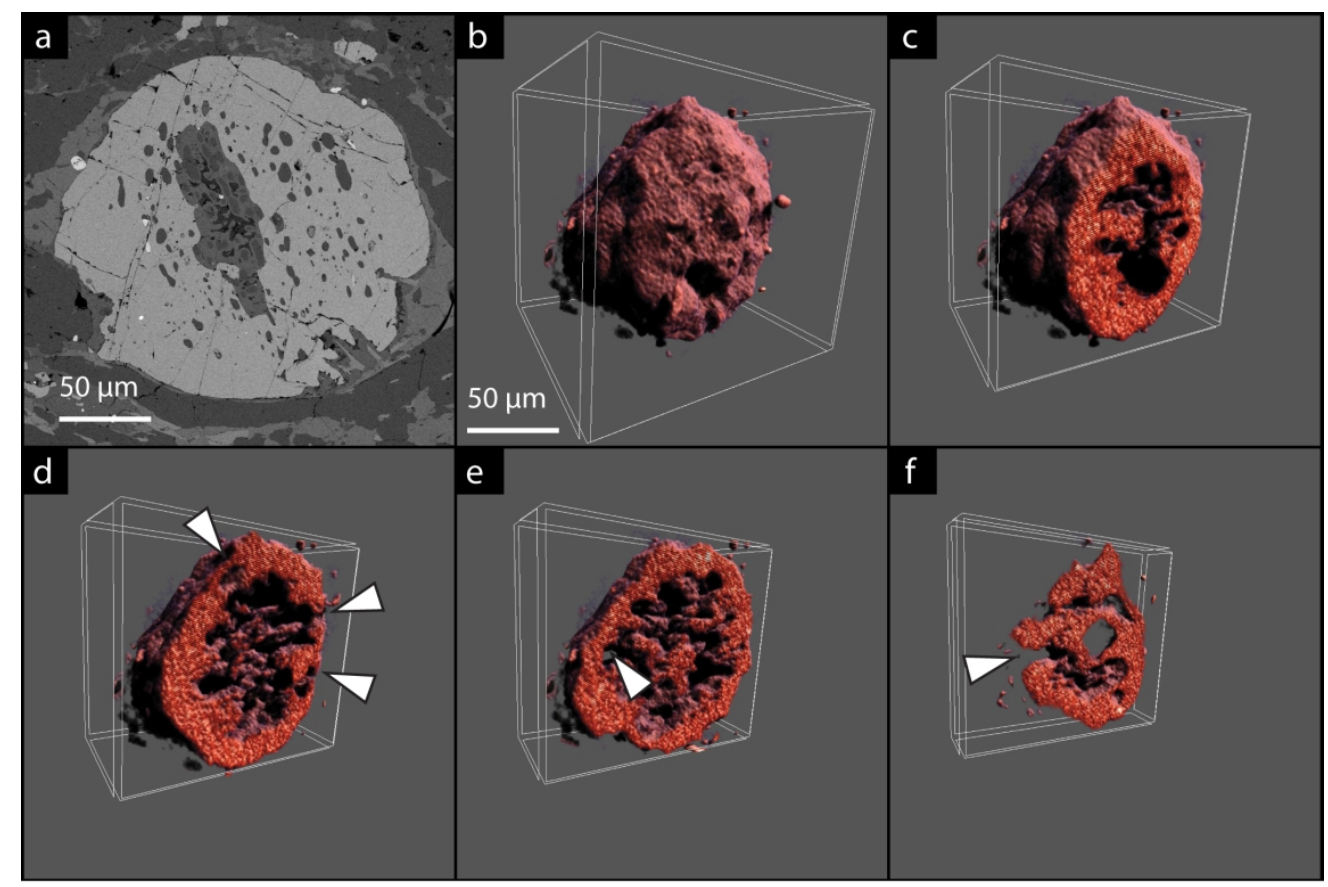

Figure 7

Figure 7. (a) Backscattered electron image of a representative garnet in the quartz-saturated granulite. (b) $3 \mathrm{D}$ reconstruction from a computed X-ray microtomography of garnet. (c-f) sequential slices of the 3D reconstructed garnet (in red) showing the channels (white arrows) connecting the irregular inclusions (transparent) to the outside matrix.

$180 \times 140 \mathrm{~mm}(300 \times 300 \mathrm{DPI})$ 


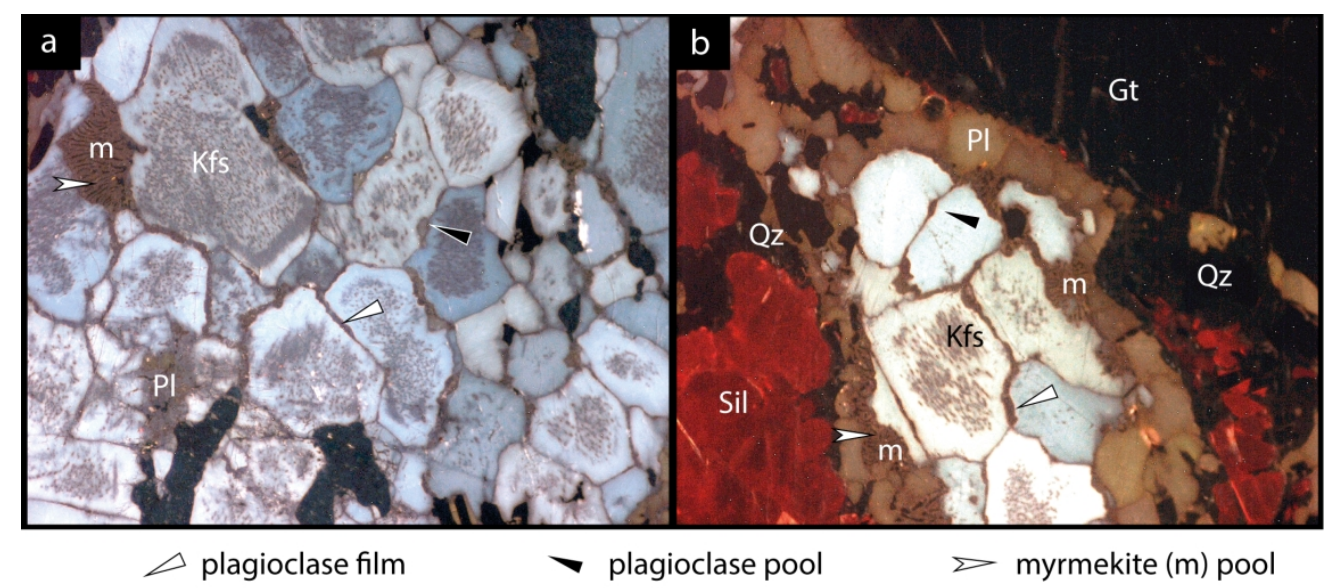

Figure 8

Figure 8. (a) Cathodoluminescence images of K-feldspar texture (blue) with plagioclase films and pool (brown) along grain boundaries. Plagioclase films are connected to myrmékite pools $(\mathrm{m})$. (b) Extensive replacement of $\mathrm{K}$-feldspar by plagioclase and myrmekites.

$180 \times 92 \mathrm{~mm}(300 \times 300 \mathrm{DPI})$ 

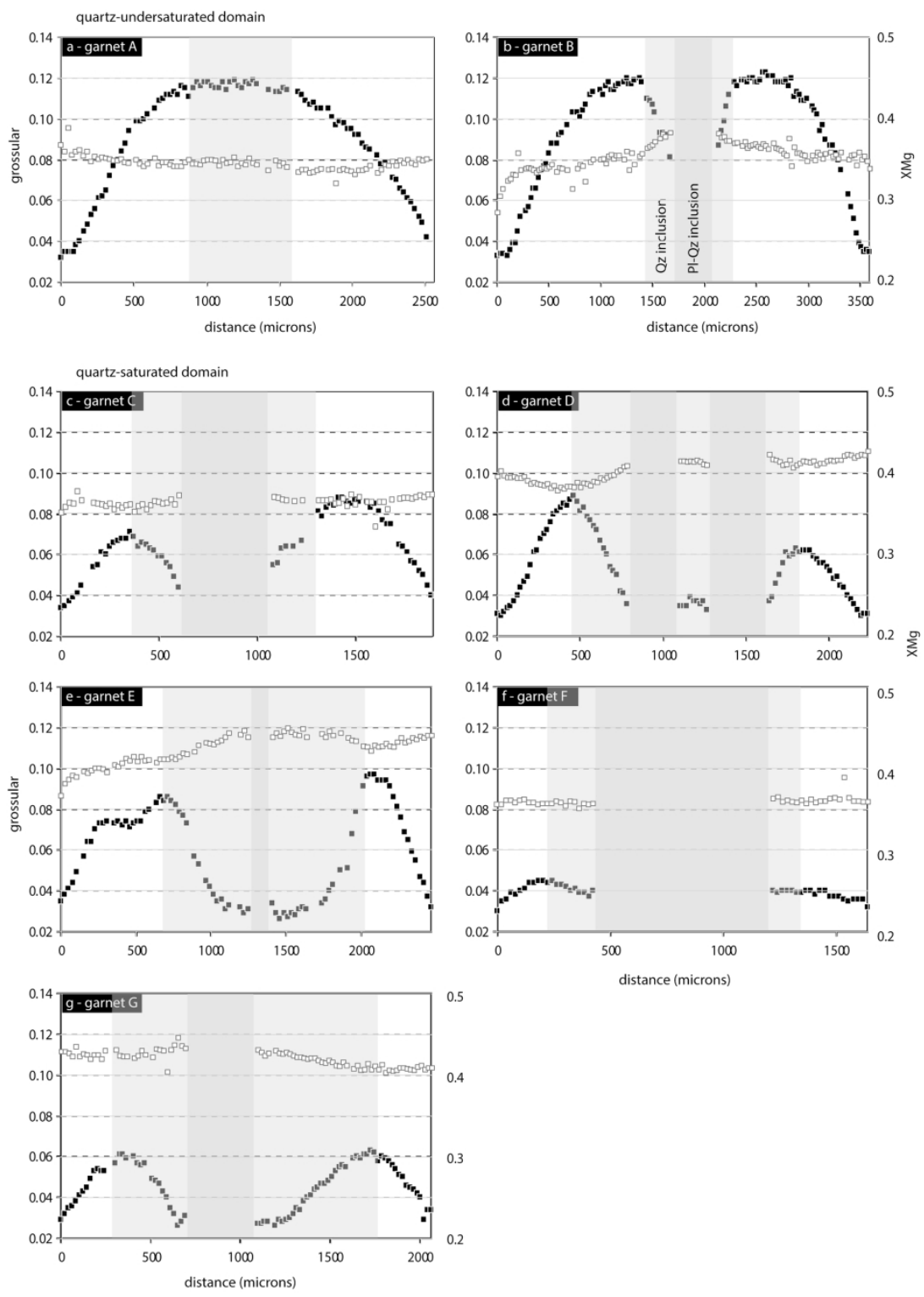

Figure 9

Figure 9. Garnet composition (black square $=$ molar amount of grossular and white square $=\mathrm{XMg}$ ). The location of each line profile is shown in figure 5 . The dark and light gray stripes correspond to plagioclasequartz inclusions and domains with minute inclusions of quartz, respectively.

$180 \times 260 \mathrm{~mm}(300 \times 300 \mathrm{DPI})$ 

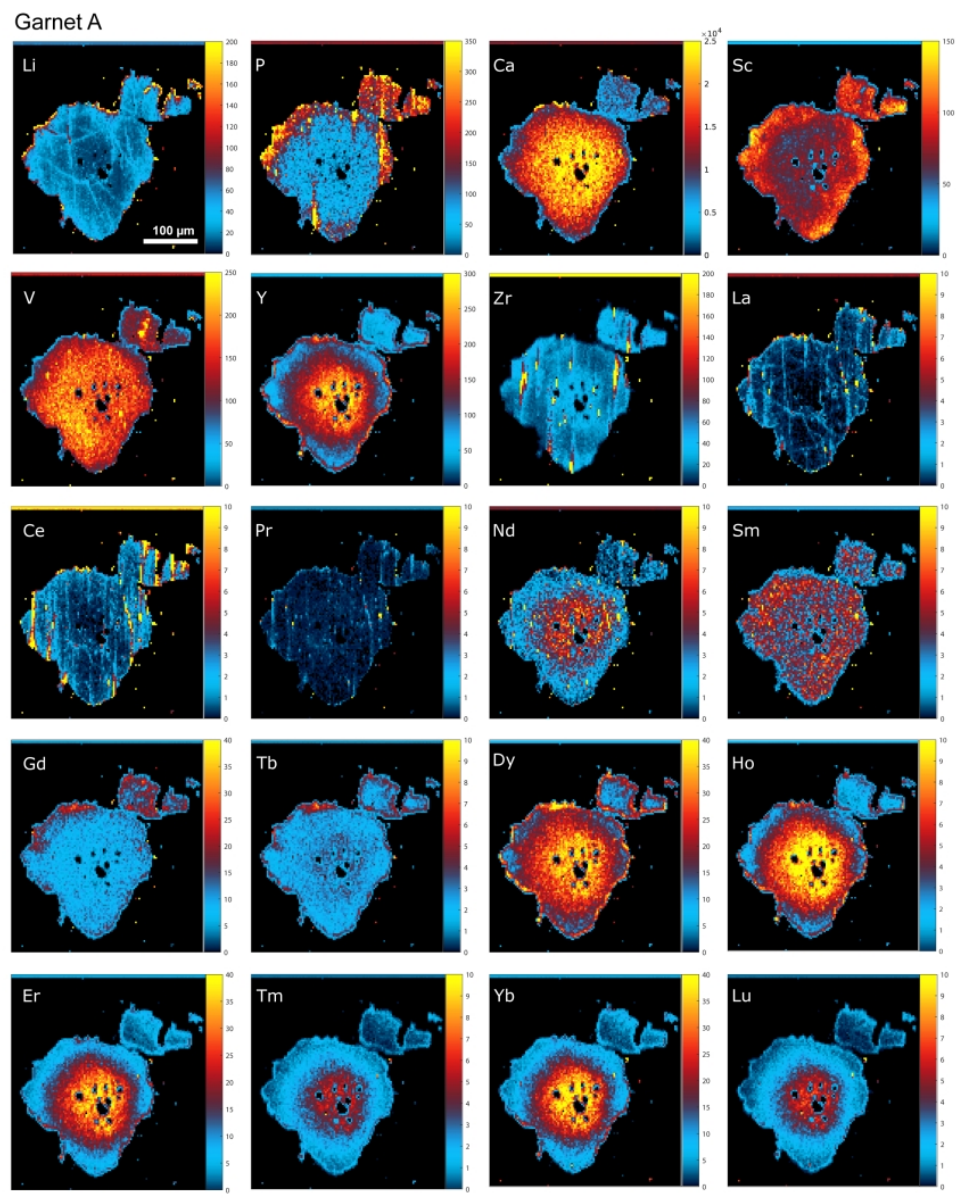

figure $10 a$

Figure 10. LA-ICP-MS trace element maps of (a) garnet A; (b) Garnet B; (c) Garnet G. Concentrations values are in ppm. The line profiles shown in Figure 11-13 are located in each case on the Phosphorus (P) map. 

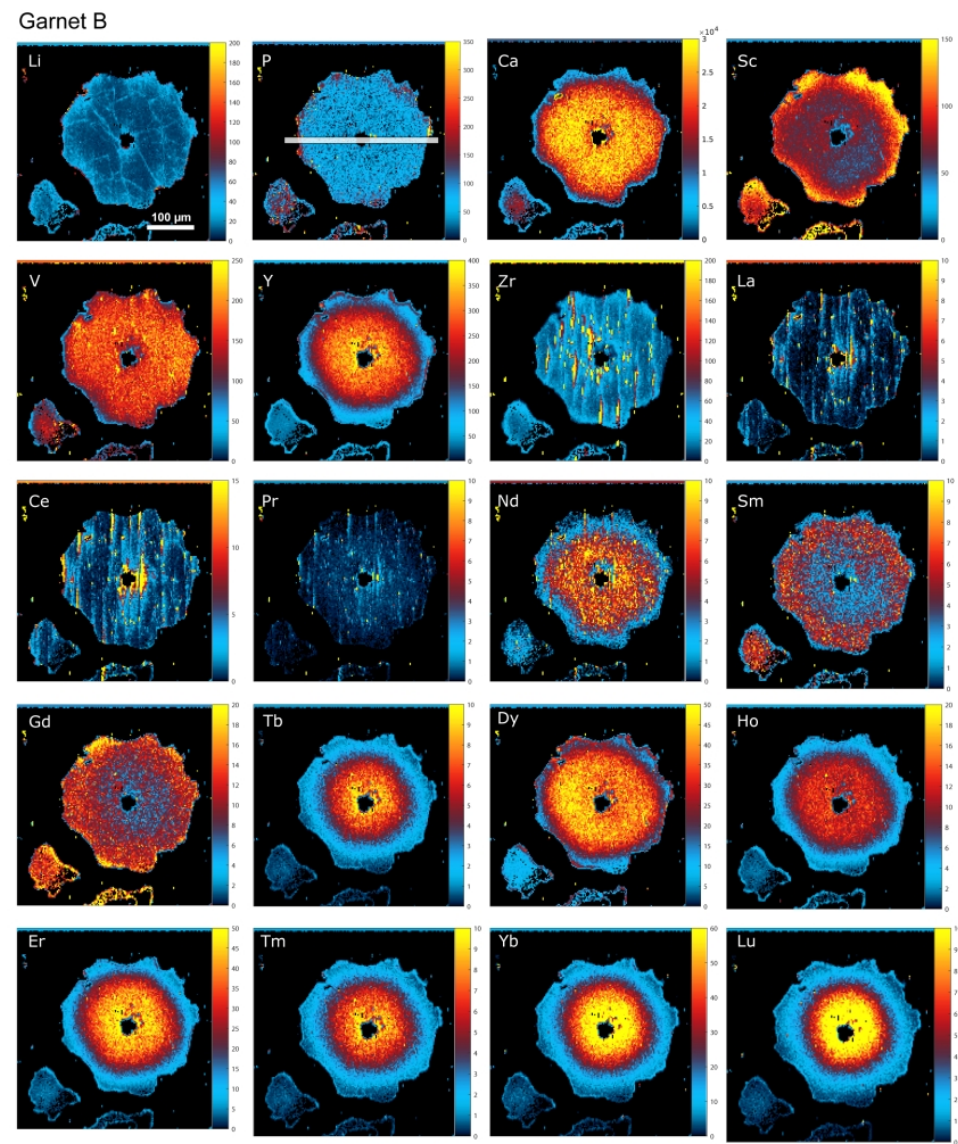

Figure 10b

Figure 10. LA-ICP-MS trace element maps of (a) garnet A; (b) Garnet B; (c) Garnet G. Concentrations values are in ppm. The line profiles shown in Figure 11-13 are located in each case on the Phosphorus (P) map. 

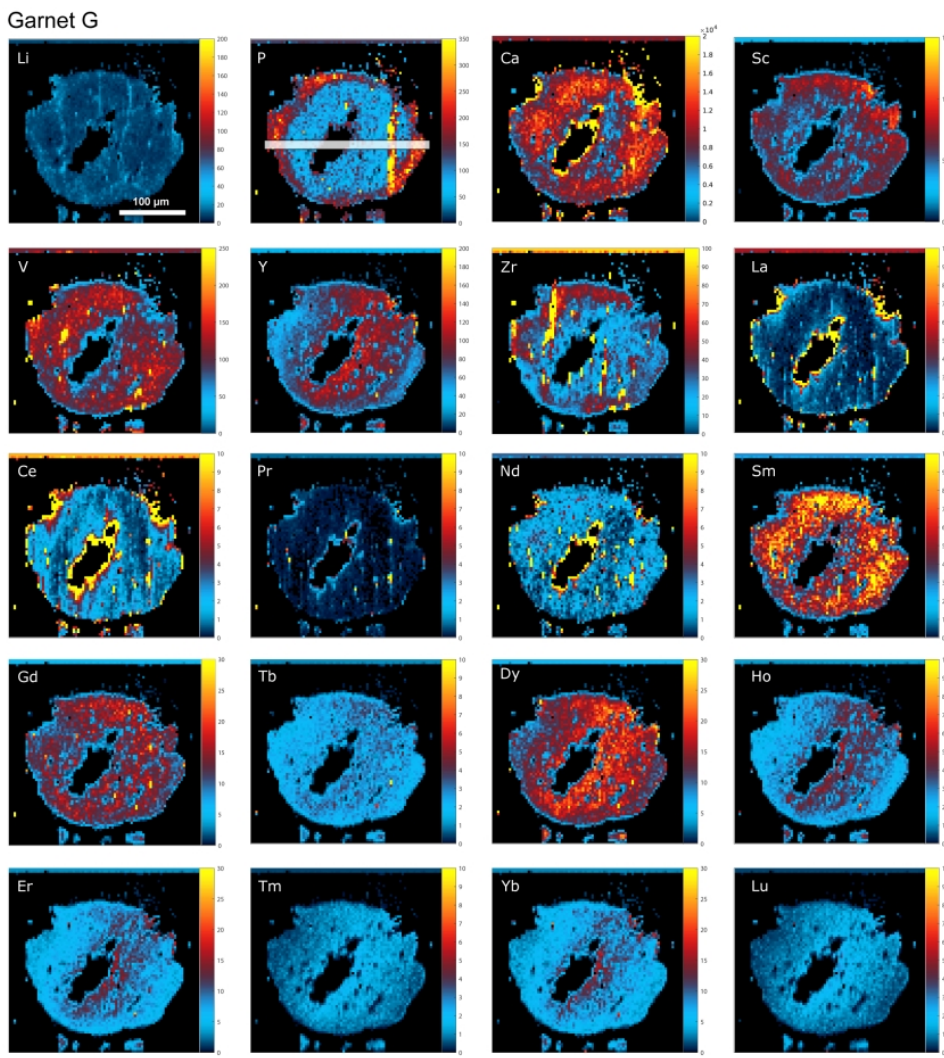

Figure 10c

Figure 10. LA-ICP-MS trace element maps of (a) garnet A; (b) Garnet B; (c) Garnet G. Concentrations values are in ppm. The line profiles shown in Figure 11-13 are located in each case on the Phosphorus (P) map. 

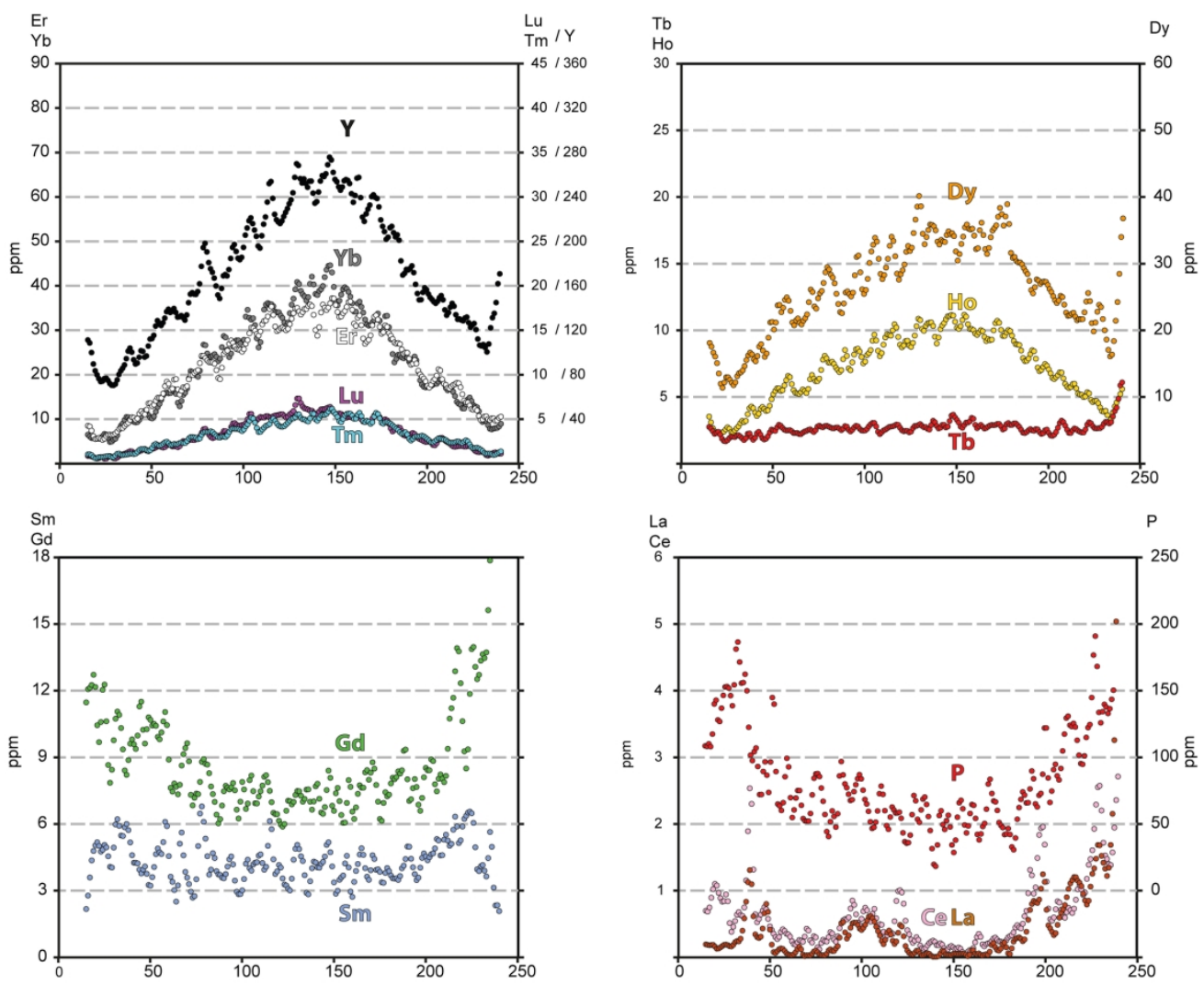

Figure 11

Figure 11. LA-ICP-MS trace element line profile of Garnet A. . See Figure 10a for traverse location. $176 \times 158 \mathrm{~mm}(300 \times 300$ DPI $)$ 

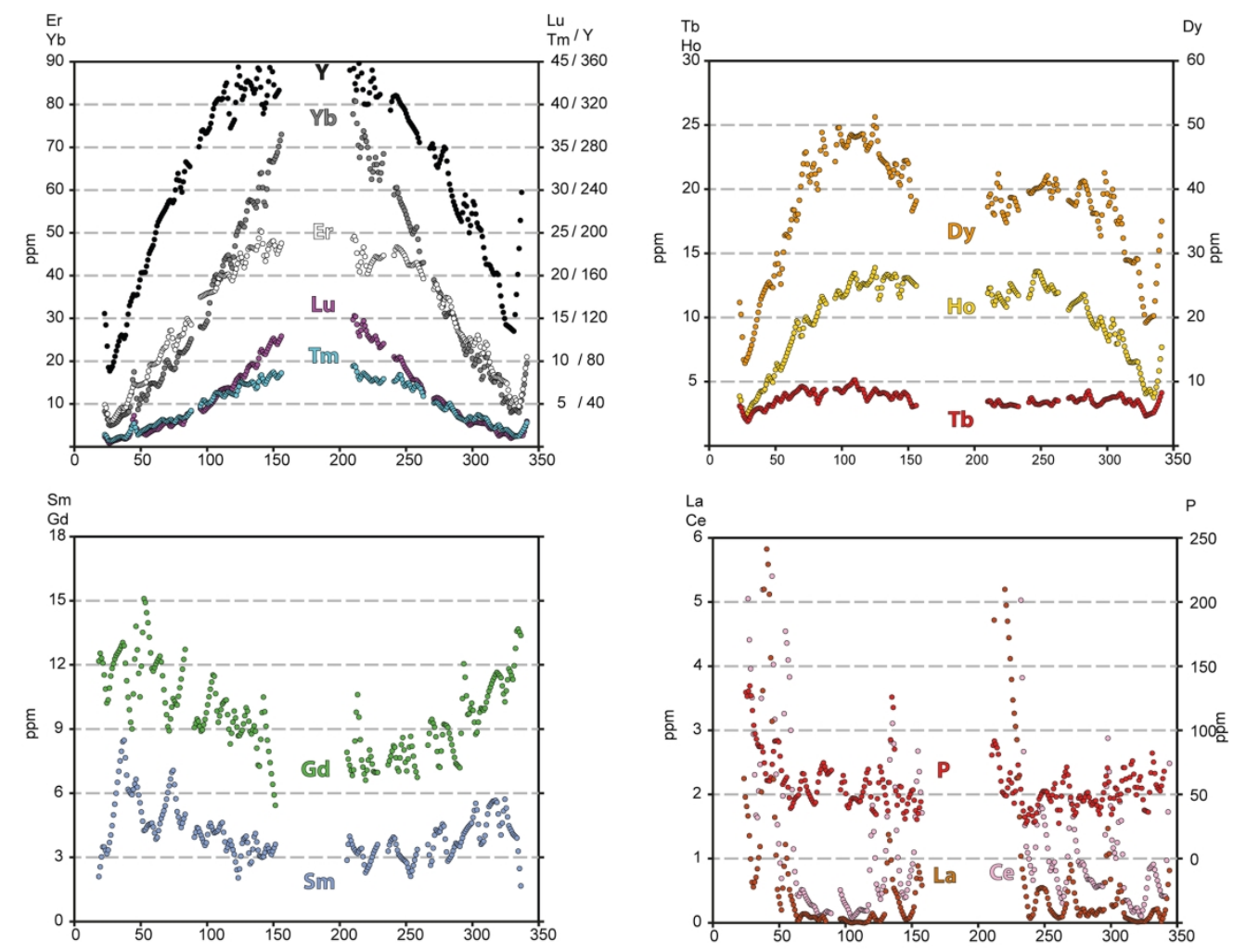

Figure 12

Figure 12. LA-ICP-MS trace element line profile of Garnet B. See Figure 10b for traverse location. 

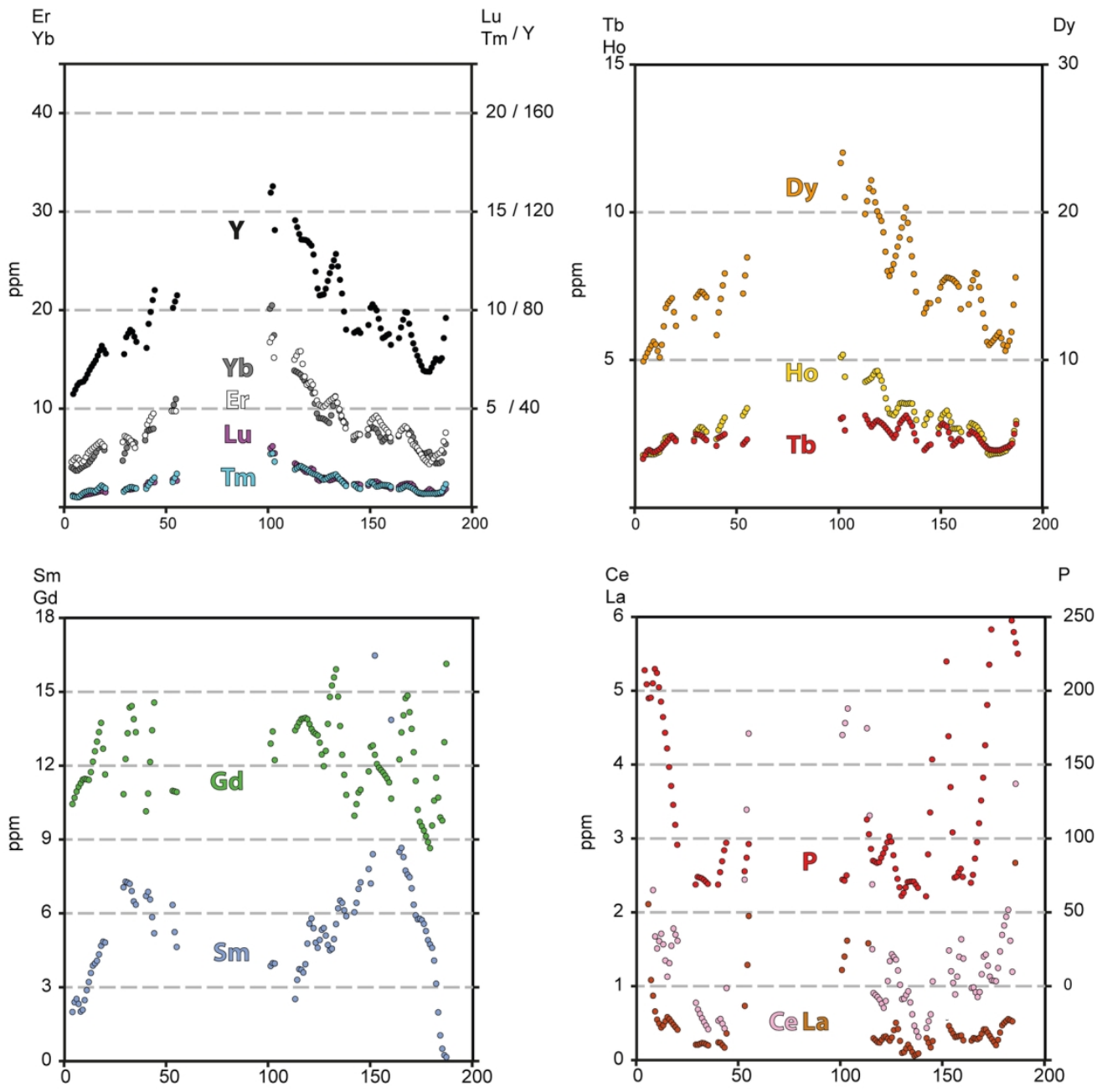

Figure 13

Figure 13. LA-ICP-MS trace element line profile of Garnet G. See Figure 10c for traverse location. $145 \times 161 \mathrm{~mm}(300 \times 300 \mathrm{DPI})$ 

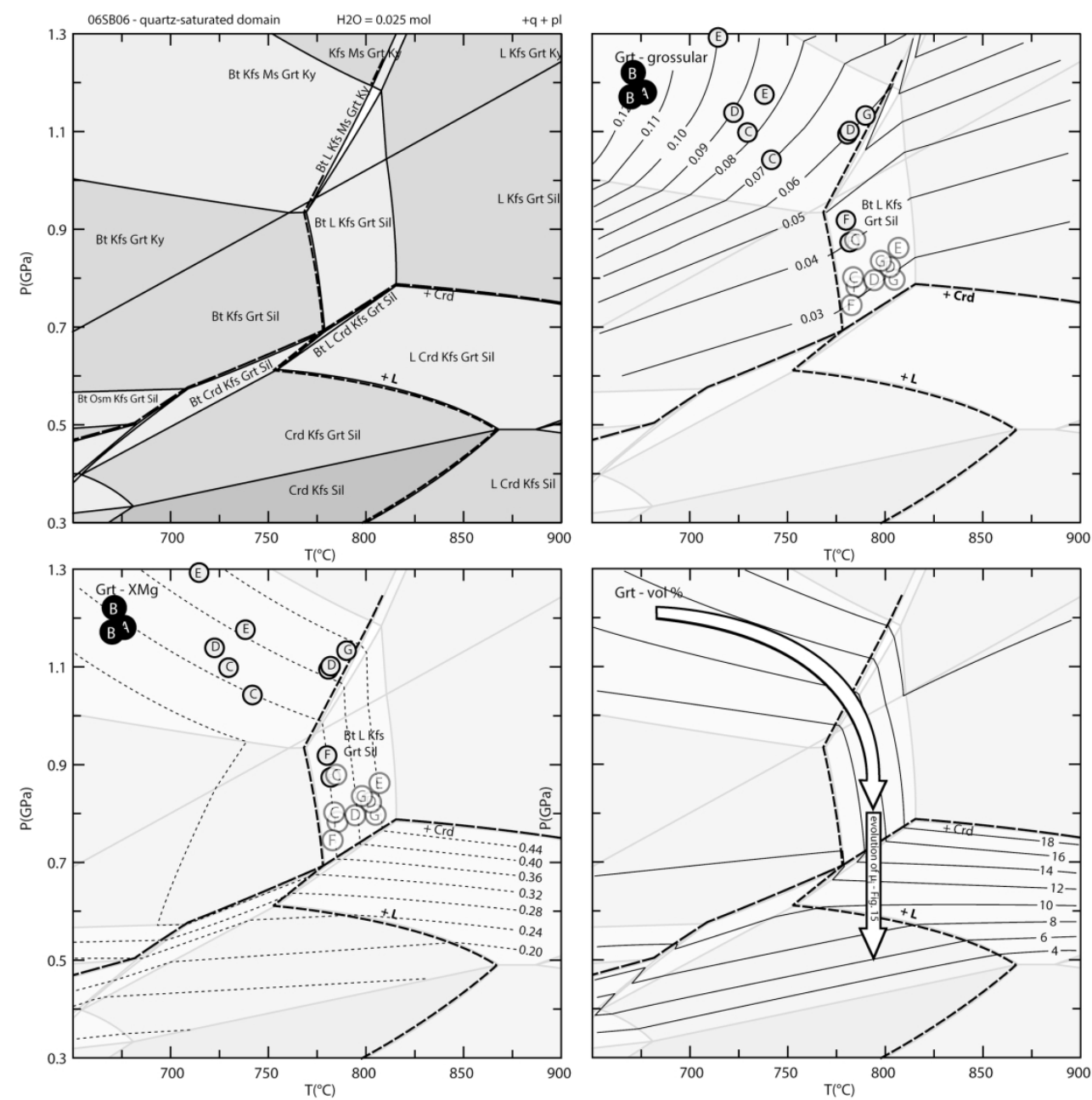

Garnet compositions :

(C) rims in the quartz-saturated domain

A high-grossular core compositions in the selvage

(E) highest grossular content in the quartz-saturated domain (modified compositions)

Figure 14

Figure 14. P-T phase diagram section computed for with quartz-saturated granulite composition (see Table 1). Circles with letters indicate the P-T conditions corresponding to measured garnet compositions. The letters refer to garnet grain labels in Figure 5. 

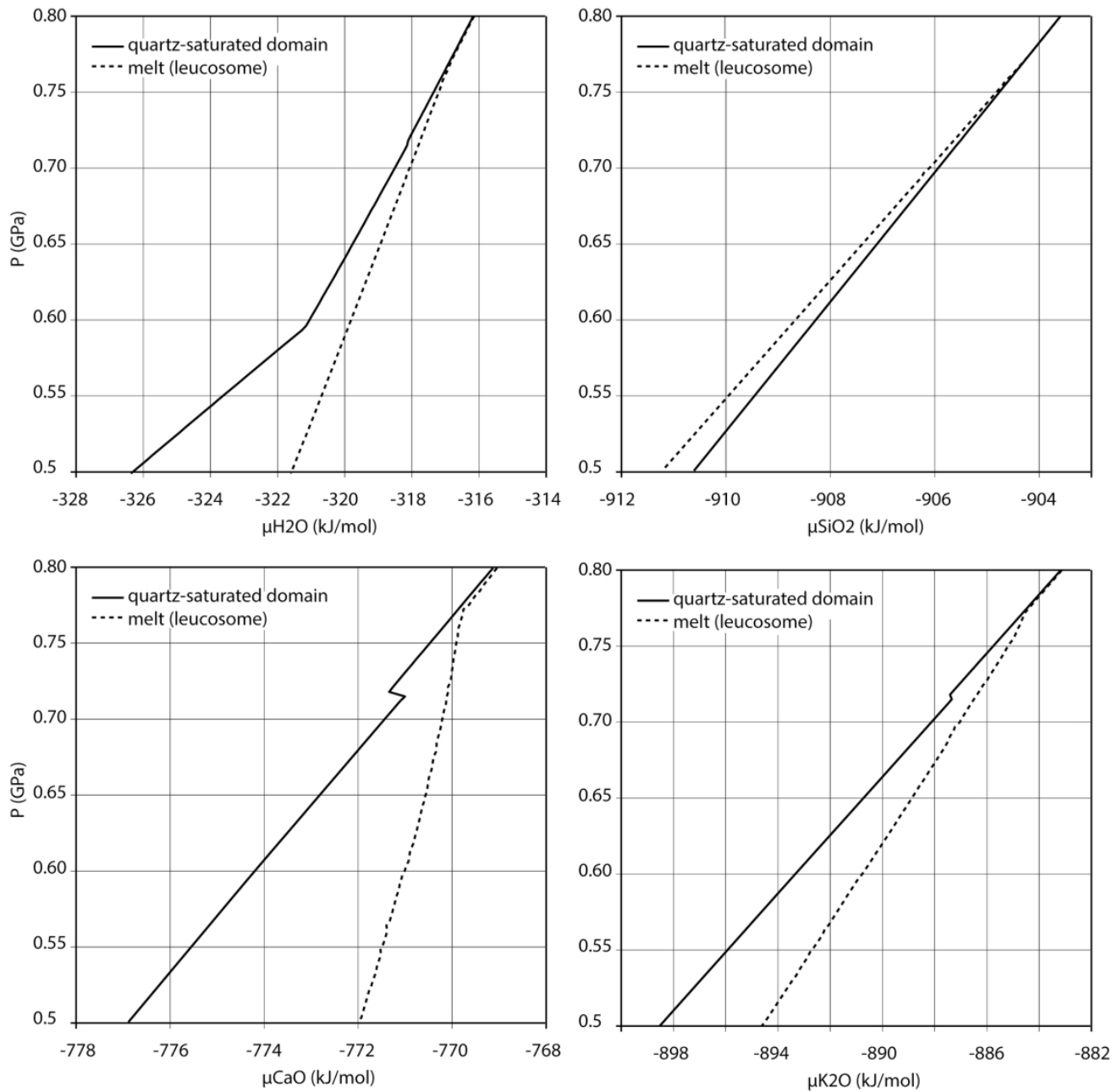

Figure 15

Figure 15. Evolution of chemical potential of $\mathrm{H} 2 \mathrm{O}, \mathrm{SiO} 2, \mathrm{CaO}$ and $\mathrm{K} 2 \mathrm{O}$ for the quartz-saturated domain (black line) and melt (dashed line) along a decompression path from 0.8 to $0.5 \mathrm{GPa}$ at $790^{\circ} \mathrm{C}$. 
Figure 17

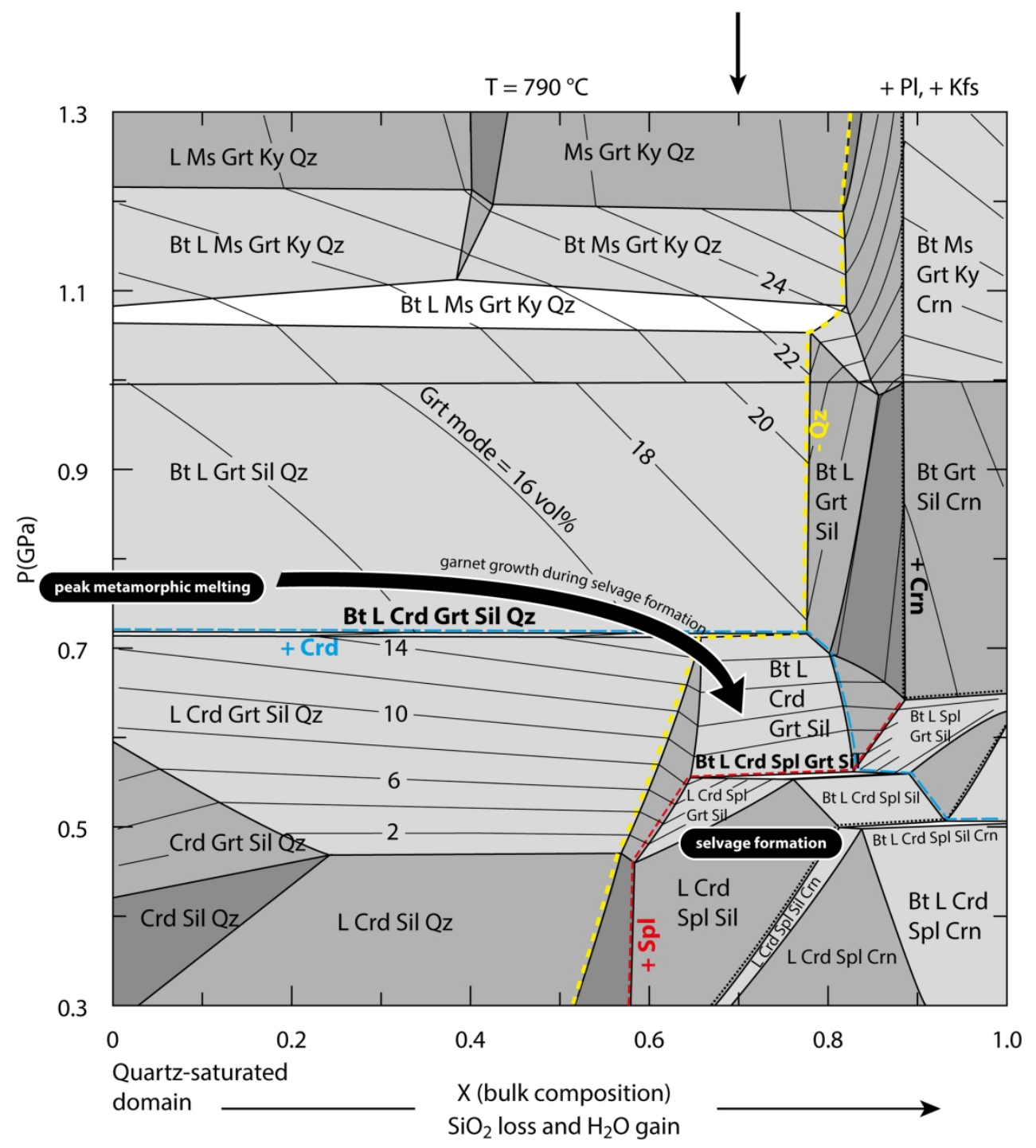

Figure 16

Figure 16. $\mathrm{P}-\mathrm{X}$ phase diagram section computed at $790^{\circ} \mathrm{C}$ with $\mathrm{X}=0$ corresponding to the quartz-saturated domain and $X=1$ corresponding to a $55 \%$ loss of $\mathrm{SiO} 2$ and $200 \%$ gain of $\mathrm{H} 2 \mathrm{O}$. See Table 1 for compositions. 


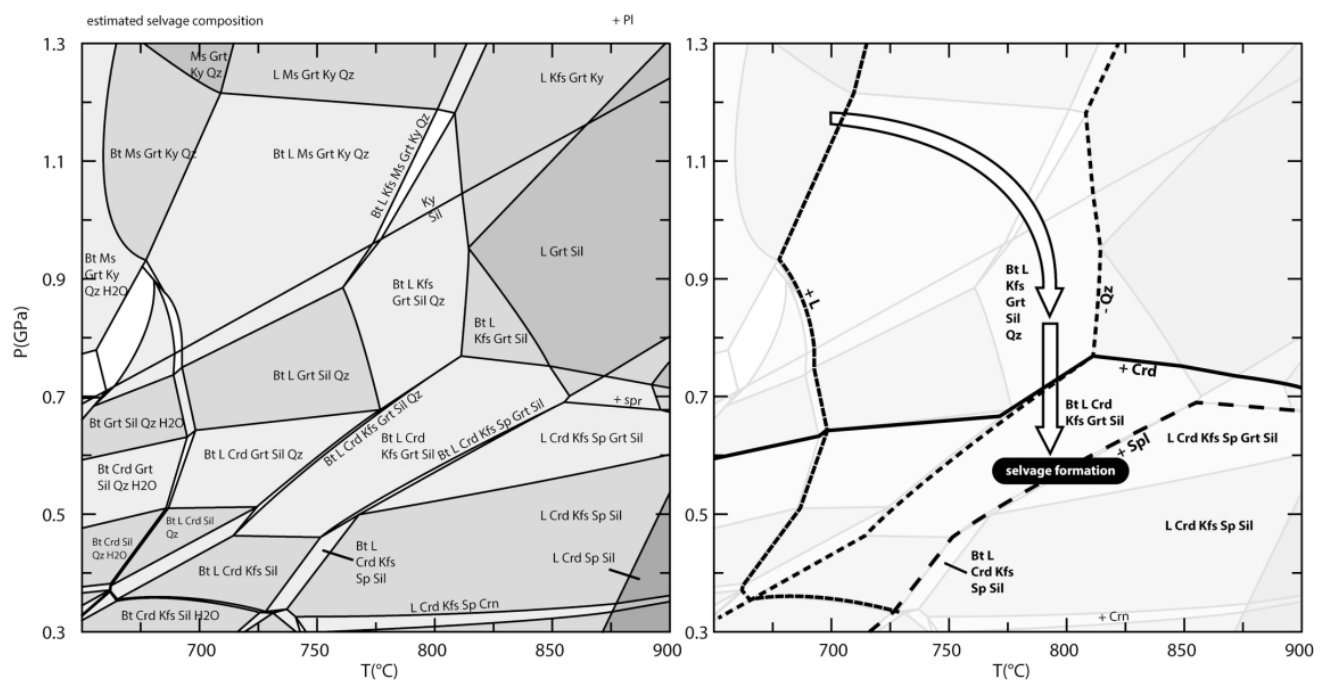

Figure 17

Figure 17. P-T phase diagram section computed with a modeled quartz-undersaturated selvage composition produced after a $47 \%$ loss of $\mathrm{SiO} 2$ and $140 \%$ gain of $\mathrm{H} 2 \mathrm{O}$. See Table 1 for compositions.

$179 \times 103 \mathrm{~mm}(300 \times 300 \mathrm{DPI})$ 


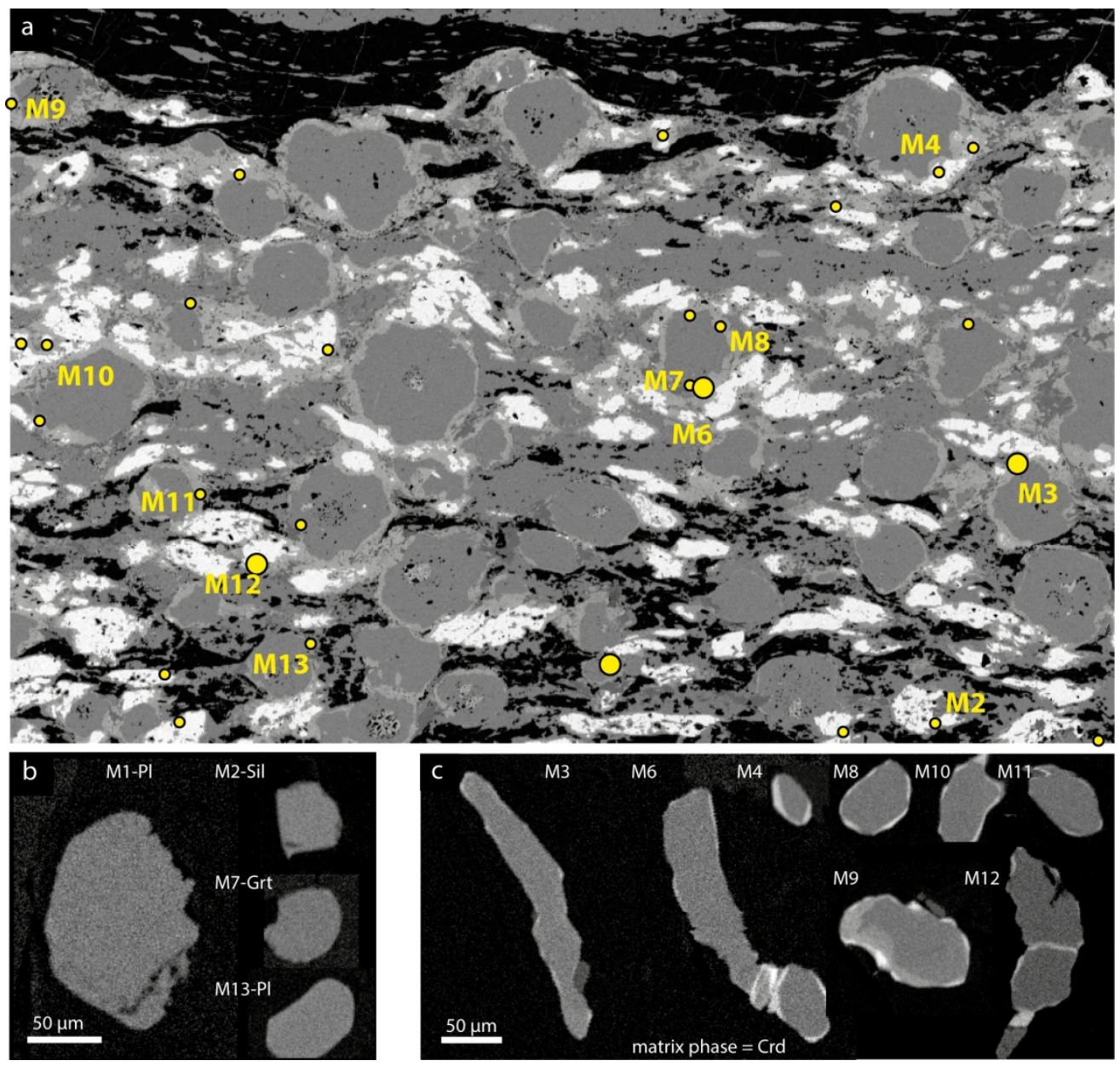

Figure 18. (a) Full thin-section X-ray Al map of sample 06SB06a showing the petrographic setting of dated monazites. (b) $Y$ map of monazite included in garnet and plagioclase. (c) $Y$ map of monazite in the cordierite-bearing matrix. Note the presence of thin Y-rich overgrowths. 

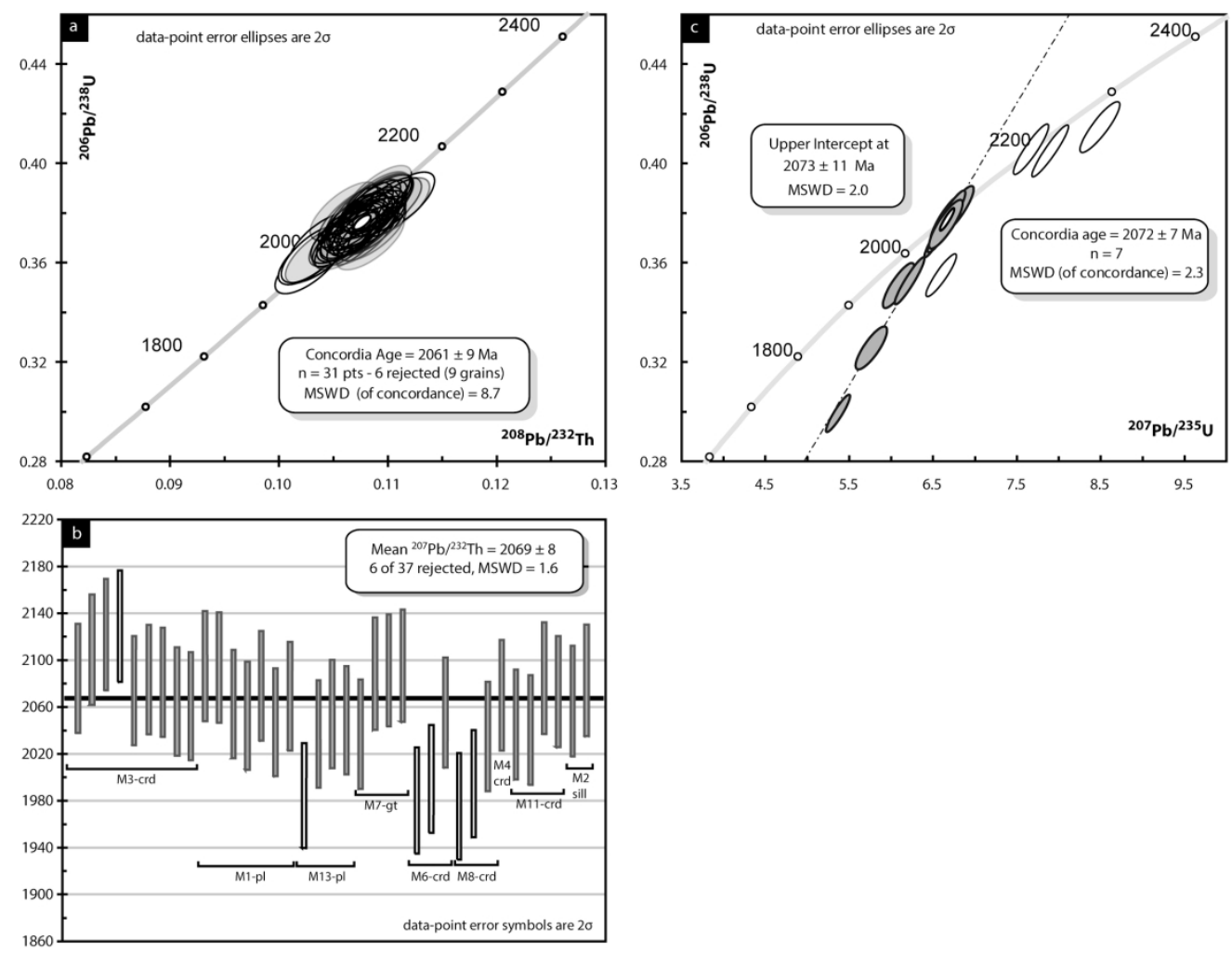

Figure 19. (a) Monazite U-Th-Pb concordia diagram. (b) Monazite Th-Pb ages. (c) Zircon U-Pb concordia diagram

$180 \times 139 \mathrm{~mm}(300 \times 300 \mathrm{DPI})$ 


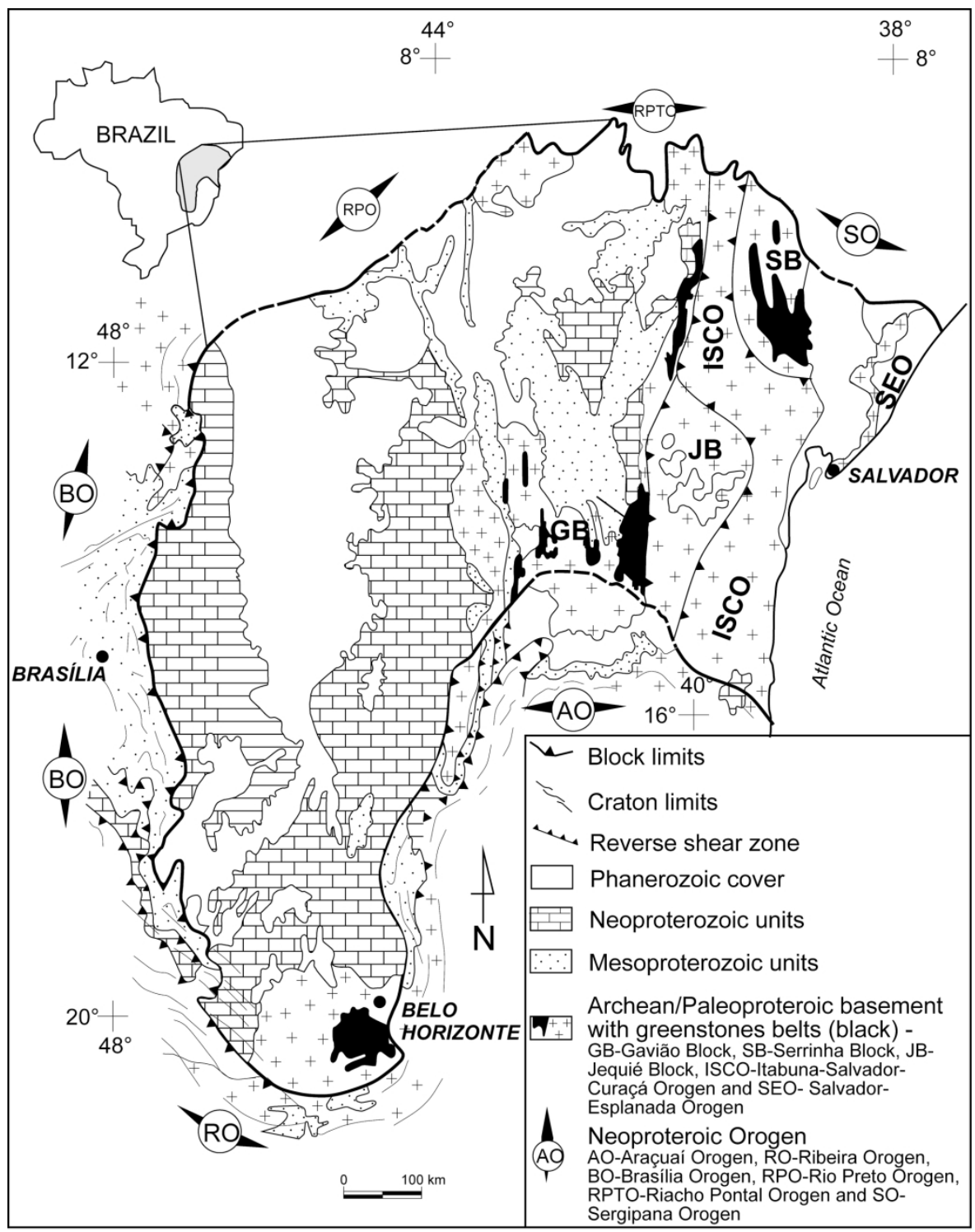

Figure 1

Figure S1. Simplified geological map of the São Francisco Craton modified after Barbosa et al. (2003). 

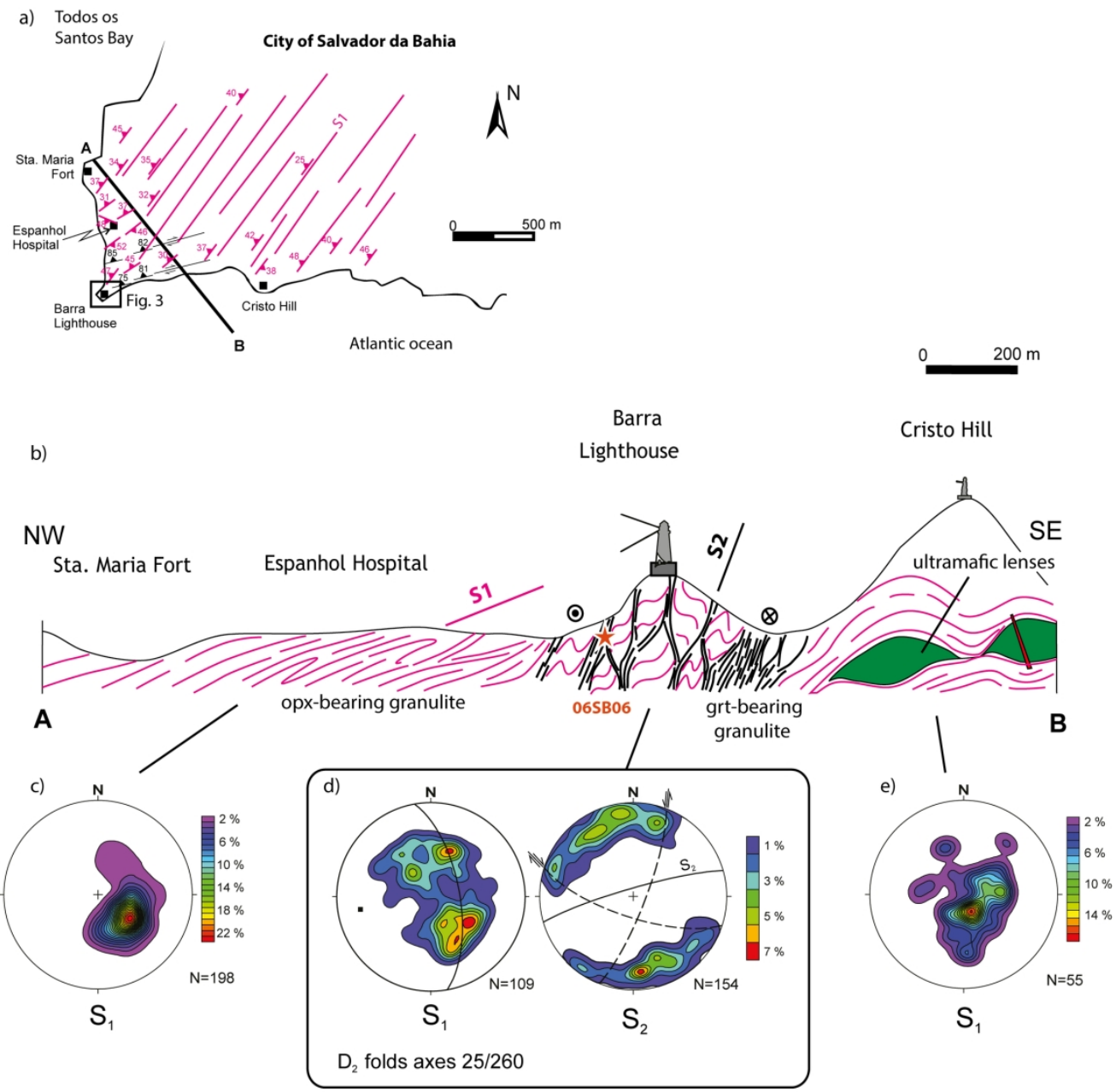

Figure S1

Figure S2. (a) Simplified structural map of the southwestern part of the city of Salvador da Bahia. (b) Simplified structural cross-section. (c) Equal-area Schmidt lower hemisphere projection of poles to S1 and $\mathrm{S} 2$ foliations (dashed lines = conjugated shear zones associated the S2 mylonitic foliation). 

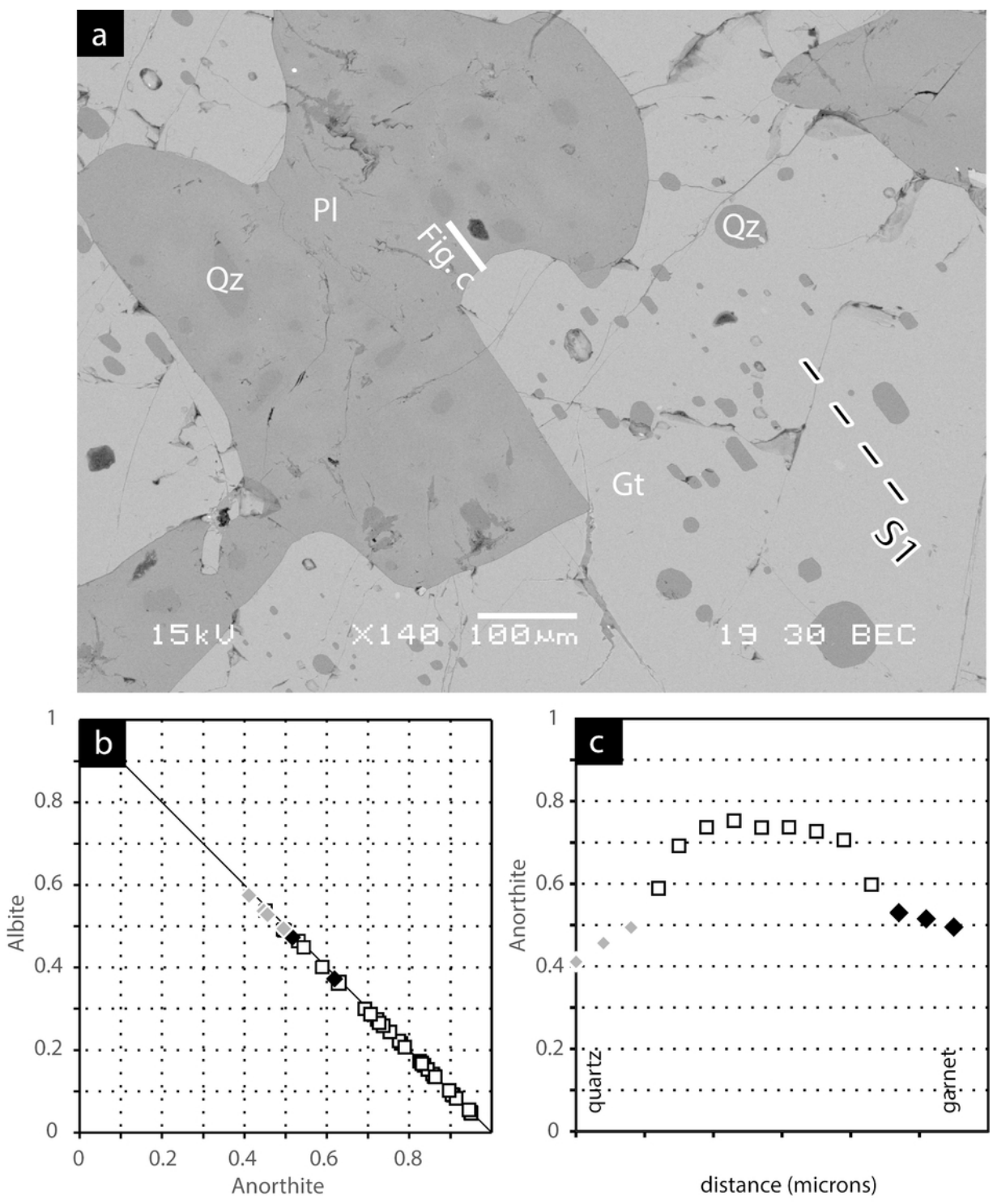

Figure S3

Figure S3. (a) Backscattered image of a polyphased plagioclase and quartz inclusion in a garnet. (b) anorthite vs albite content in mole of plagioclase. Grey and black diamonds are plagioclase composition in contact with quartz and garnet respectively. (c) Profile showing the evolution of plagioclase composition in contact with quartz and garnet. See location of the profile in figure a. 

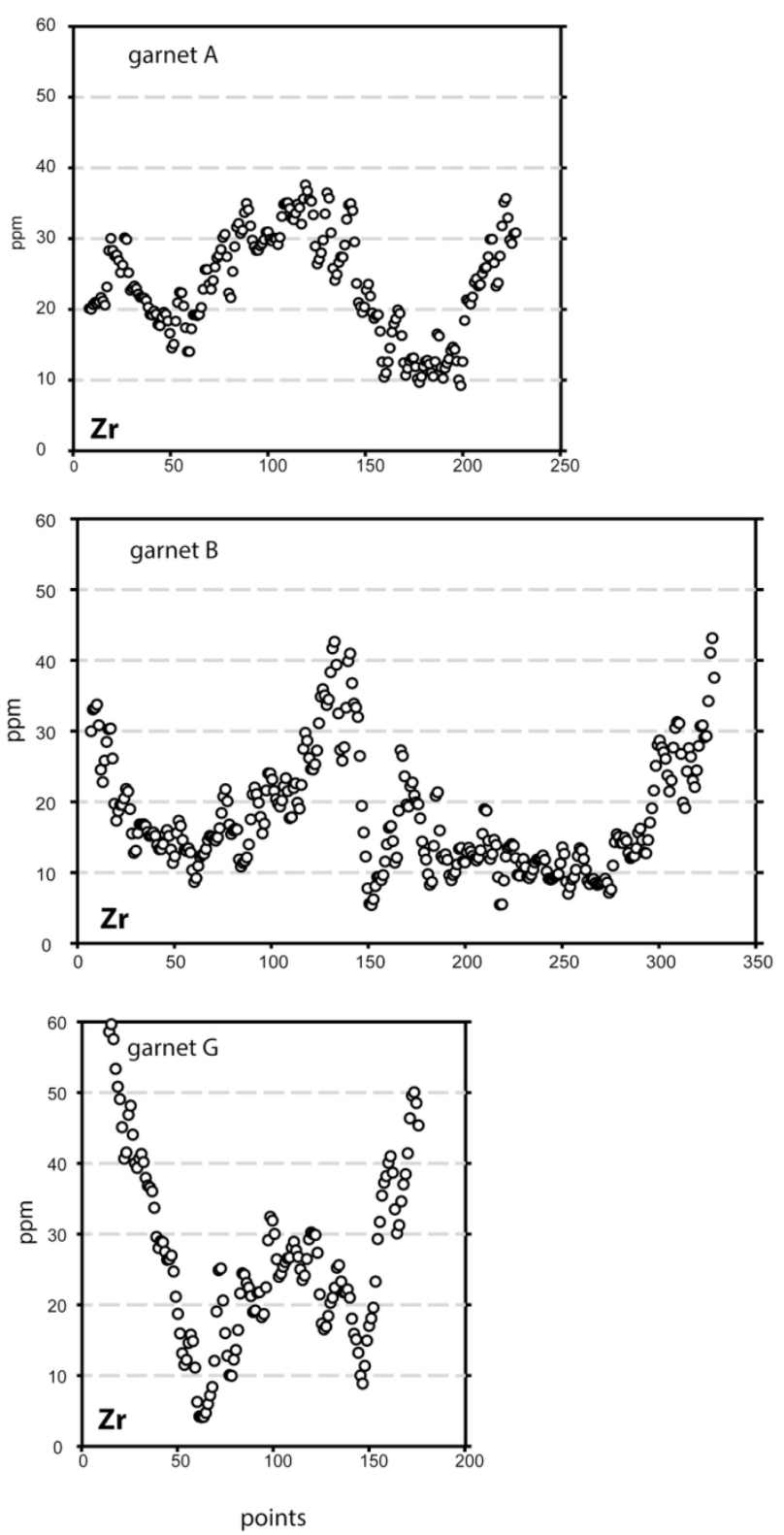

Figure S4. LA-ICP-MS Zr line profile of garnet A, B and G $80 \times 156 \mathrm{~mm}(300 \times 300 \mathrm{DPI})$ 
Table 1

\begin{tabular}{|c|c|c|c|c|c|}
\hline & \multirow{2}{*}{$\begin{array}{c}\text { P-T pseudosection Figure } 14 \\
\text { 06SB06 - qtz-saturated granulite }\end{array}$} & \multirow{2}{*}{$\begin{array}{c}\text { P- } \mu \text { diagrams in Figure } 15 \\
\text { melt produced } \\
@ 0.8 \mathrm{GPa} \text { and } 790^{\circ} \mathrm{C}\end{array}$} & \multicolumn{2}{|c|}{$\mathrm{P}-\mathrm{X}$ diagram in Figure 16} & \multirow{2}{*}{$\begin{array}{l}\text { P-T pseudosection in Figure } 17 \\
\text { selvage composition after } \mathrm{H}_{2} \mathrm{O} \\
\text { and } \mathrm{SiO}_{2} \text { transfer }(\mathrm{X}=0.70)\end{array}$} \\
\hline & & & $X=0$ & $x=1$ & \\
\hline & $w t \%$ & $\mathrm{wt} \%$ & wt $\%$ & wt\% & $\mathrm{wt} \%$ \\
\hline $\mathrm{SiO}_{2}$ & 64.22 & 69.12 & 64.22 & 36.25 & 48.21 \\
\hline $\mathrm{Al}_{2} \mathrm{O}_{3}$ & 22.93 & 13.94 & 22.93 & 39.84 & 32.61 \\
\hline $\mathrm{FeO}$ & 5.76 & 0.42 & 5.76 & 10 & 8.19 \\
\hline $\mathrm{MgO}$ & 2.89 & 0.15 & 2.89 & 5.02 & 4.11 \\
\hline $\mathrm{CaO}$ & 1.25 & 0.74 & 1.25 & 2.17 & 1.77 \\
\hline $\mathrm{K}_{2} \mathrm{O}$ & 1.86 & 6.51 & 1.86 & 3.23 & 2.64 \\
\hline $\mathrm{Na}_{2} \mathrm{O}$ & 0.64 & 2.28 & 0.64 & 1.11 & 0.91 \\
\hline \multirow[t]{2}{*}{$\mathrm{H}_{2} \mathrm{O}$} & 0.46 & 6.85 & 0.46 & 2.38 & 1.56 \\
\hline & $\mathrm{mol}$ & $\mathrm{mol}$ & mol & mol & $\mathrm{mol}$ \\
\hline $\mathrm{SiO}_{2}$ & 1.053 & 1.565 & 1.053 & 0.342 & 0.556 \\
\hline $\mathrm{Al}_{2} \mathrm{O}_{3}$ & 0.222 & 0.186 & 0.222 & 0.222 & 0.222 \\
\hline $\mathrm{FeO}$ & 0.079 & 0.008 & 0.079 & 0.079 & 0.079 \\
\hline $\mathrm{MgO}$ & 0.071 & 0.005 & 0.071 & 0.071 & 0.071 \\
\hline $\mathrm{CaO}$ & 0.022 & 0.018 & 0.022 & 0.022 & 0.022 \\
\hline $\mathrm{K}_{2} \mathrm{O}$ & 0.019 & 0.094 & 0.019 & 0.019 & 0.019 \\
\hline $\mathrm{Na}_{2} \mathrm{O}$ & 0.010 & 0.050 & 0.010 & 0.010 & 0.010 \\
\hline $\mathrm{H}_{2} \mathrm{O}$ & 0.025 & 0.517 & 0.025 & 0.075 & 0.060 \\
\hline
\end{tabular}


Table S1

\begin{tabular}{llll}
\hline solid solution models & abbreviation in Perple_X & abbreviation used & references \\
\hline Biotite & Bio(TCC) & Bio & Tajcmanova et al. (2009) \\
Orthopyrexene & Opx(HP) & Opx & Powell \& Holland (1999) \\
Melt & melt(HP) & $\mathrm{L}$ & White et al. (2001) \\
K-feldspar & $\mathrm{San}$ & $\mathrm{Kf}$ & Waldbaum \& Thompson (1968) \\
Plagioclase & $\mathrm{Pl}(\mathrm{h})$ & $\mathrm{pl}$ & Newton et al. (1981) \\
Garnet & $\mathrm{Gt}(\mathrm{WPH})$ & $\mathrm{Gt}$ & White et al. (2007) \\
Spinel & $\mathrm{Sp}(\mathrm{HP})$ & $\mathrm{Sp}$ & \\
Sapphirine & $\mathrm{Sapp}(\mathrm{KWP})$ & $\mathrm{Spr}$ & Kelsey et al. (2014) \\
White mica & $\mathrm{Mica}(\mathrm{CHA})$ & $\mathrm{Mu}$ & Auzanneau et al. (2009) \\
Cordierite & $\mathrm{hCrd}$ & $\mathrm{Crd}$ & Holland et al. (1996) \\
\hline
\end{tabular}

\section{REFERENCES}

Auzanneau, E., Schmidt, M. W., Vielzeuf, D., \& D Connolly, J. A. (2009). Titanium in phengite : A geobarometer for high temperature eclogites. Contributions to Mineralogy and Petrology, 159(1), 1. https://doi.org/10.1007/s00410-009-0412-7

Holland, T. J. B., Babu, E. V. S. S. K., \& Waters, D. J. (1996). Phase relations of osumilite and dehydration melting in pelitic rocks : A simple thermodynamic model for the KFMASH system. Contributions to Mineralogy and Petrology, 124(3), 383-394.

https://doi.org/10.1007/s004100050198

Kelsey, D. E., White, R. W., Holland, T. J. B., \& Powell, R. (2004). Calculated phase equilibria in K2O-FeO-MgO-Al2O3-SiO2-H2O for sapphirine-quartz-bearing mineral assemblages. Journal of Metamorphic Geology, 22(6), 559-578. https://doi.org/10.1111/j.1525-1314.2004.00533.x

Newton, R. C., Charlu, T. V., \& Kleppa, O. J. (1980). Thermochemistry of the high structural state plagioclases. Geochimica et Cosmochimica Acta, 44(7), 933-941. https: / /doi.org/10.1016/0016-7037(80)90283-5

Powell, R., \& Holland, T. (1999). Relating formulations of the thermodynamics of mineral solid solutions; activity modeling of pyroxenes, amphiboles, and micas. American Mineralogist, 84(1-2), 1-14. https://doi.org/10.2138/am-1999-1-201

Tajčmanová, L., Connolly, J. a. D., \& Cesare, B. (2009). A thermodynamic model for titanium and ferric iron solution in biotite. Journal of Metamorphic Geology, 27(2), 153-165. https://doi.org/10.1111/j.1525-1314.2009.00812.x 
Waldbaum, D. R., \& Thompson, J. B. (1968). Mixing Properties Of Sanidine Crystalline Solutions .2. Calculations Based On Volume Data. American Mineralogist, 2000-2017.

White, R. W., Powell, R., \& Holland, T. J. B. (2001). Calculation of partial melting equilibria in the system Na2O-CaO-K2O-FeO-MgO-Al2O3-SiO2-H2O (NCKFMASH). Journal of Metamorphic Geology, 19(2), 139-153. https://doi.org/10.1046/j.0263-4929.2000.00303.x

White, R. W., Powell, R., \& Holland, T. J. B. (2007). Progress relating to calculation of partial melting equilibria for metapelites. Journal of Metamorphic Geology, 25(5), 511-527. https://doi.org/10.1111/j.1525-1314.2007.00711.x 


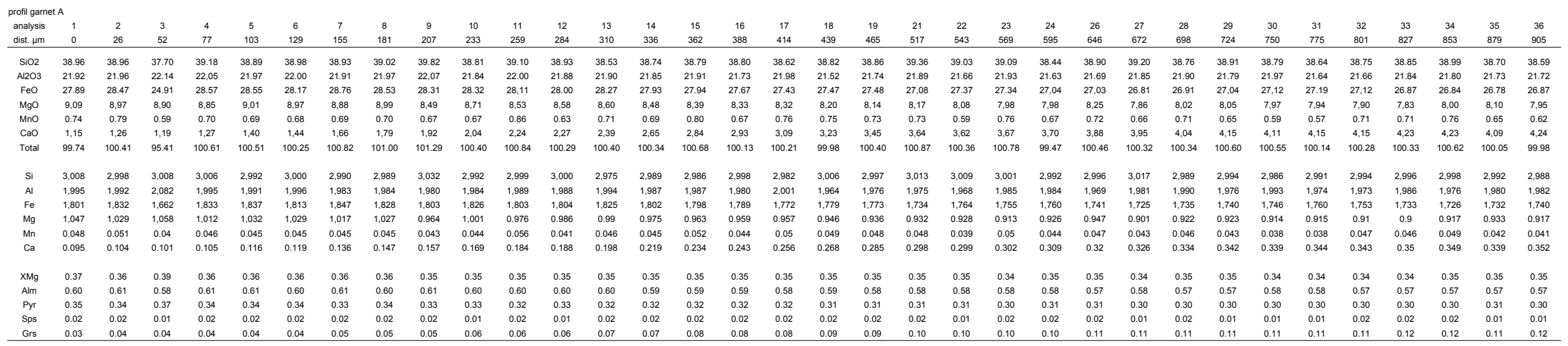

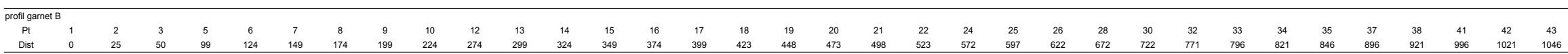

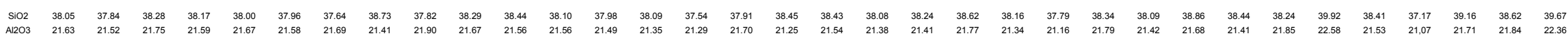

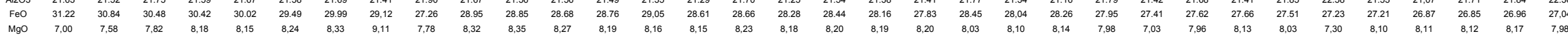

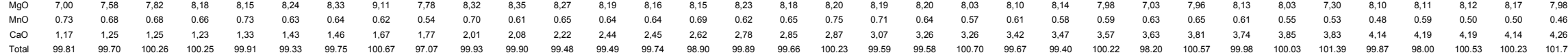

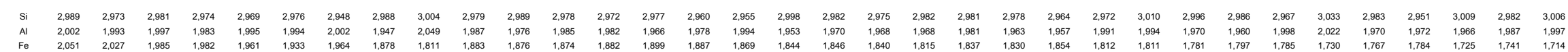

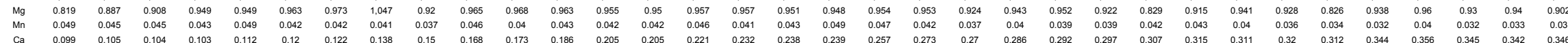
$\begin{array}{cllllllllllllllllllllllllllllllllllllllll}\text { MgRat } & 0.29 & 0.31 & 0.31 & 0.32 & 0.33 & 0.33 & 0.33 & 0.36 & 0.34 & 0.34 & 0.34 & 0.34 & 0.34 & 0.33 & 0.34 & 0.34 & 0.34 & 0.34 & 0.34 & 0.34 & 0.34 & 0.34 & 0.34 & 0.34 & 0.31 & 0.34 & 0.34 & 0.34 & 0.32 & 0.35 & 0.35 & 0.35 & 0.35 & 0.35 \\ \text { Alm } & 0.68 & 0.66 & 0.65 & 0.64 & 0.64 & 0.63 & 0.63 & 0.61 & 0.62 & 0.62 & 0.61 & 0.61 & 0.61 & 0.61 & 0.61 & 0.60 & 0.60 & 0.60 & 0.59 & 0.59 & 0.60 & 0.59 & 0.59 & 0.59 & 0.61 & 0.58 & 0.58 & 0.58 & 0.60 & 0.57 & 0.57 & 0.57 & 0.57 & 0.57\end{array}$

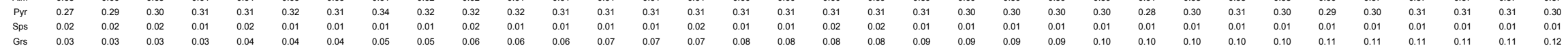

\begin{tabular}{|c|c|c|c|c|c|c|c|c|c|c|c|c|c|c|c|c|c|c|c|c|c|c|c|c|c|c|c|c|c|c|c|c|c|c|}
\hline $\begin{array}{l}\text { ofil garnet } \\
\mathrm{Pt}\end{array}$ & ${ }_{1}{ }_{1}$ & 2 & 3 & 4 & 5 & 6 & 9 & 10 & 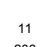 & 12 & 13 & 14 & 15 & 16 & 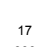 & & 19 & 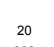 & & 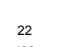 & & . & 25 & 26 & 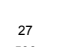 & & 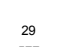 & 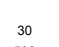 & & 54 & 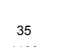 & 36 & & \\
\hline Dist & 0 & 21 & 41 & 62 & 82 & 103 & 165 & 186 & 206 & 227 & 247 & 268 & 289 & 309 & 330 & 350 & 371 & 392 & 412 & 433 & 454 & 474 & 495 & 516 & 536 & 557 & 577 & 598 & 1081 & 1102 & 1122 & 1143 & 1184 & 1225 \\
\hline sior & 39.42 & 39.23 & 37.61 & 38.84 & 38.73 & 38.87 & 38.60 & 38.30 & 3.88 & 38.78 & 38.08 & 38.63 & 38.07 & 38.07 & 38.99 & 38.75 & 37.78 & 38.67 & 38.58 & 99.13 & 39.48 & 8.97 & 8.55 & 38.96 & 8.56 & 38.53 & 8.86 & 38.77 & 8.65 & 8.30 & 49 & 8.58 & 8.64 & 8.30 \\
\hline $\begin{array}{l}\mathrm{Al}^{\mathrm{A} 203} \\
\mathrm{FeO}\end{array}$ & $\begin{array}{l}21.95 \\
28.94\end{array}$ & $\begin{array}{l}22.19 \\
29.91\end{array}$ & $\begin{array}{l}21.36 \\
28.56\end{array}$ & $\begin{array}{l}21.80 \\
2865\end{array}$ & $\begin{array}{l}21.77 \\
28.70\end{array}$ & $\begin{array}{r}21.89 \\
2840\end{array}$ & $\begin{array}{l}21.85 \\
27.96\end{array}$ & 99 & $\begin{array}{l}21.87 \\
27.96\end{array}$ & $\begin{array}{l}21.69 \\
27.96\end{array}$ & 86 & & $\begin{array}{l}21.92 \\
28.13\end{array}$ & 82 & & $\begin{array}{l}21.63 \\
2767\end{array}$ & & 68 & $\begin{array}{l}21.69 \\
2767\end{array}$ & & $\begin{array}{l}22,10 \\
270\end{array}$ & $\begin{array}{l}22.27 \\
27\end{array}$ & & $\begin{aligned} 21.69\end{aligned}$ & $\begin{array}{l}21.92 \\
28.12\end{array}$ & & & & & 21.81 & 1.90 & & 21.66 & 21.56 \\
\hline 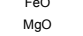 & 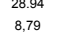 & $\begin{array}{l}29,01 \\
9,08\end{array}$ & $\begin{array}{c}28.52 \\
9,11\end{array}$ & $\begin{array}{l}28.65 \\
9,11\end{array}$ & $\begin{array}{l}28.70 \\
9.73\end{array}$ & $\begin{array}{l}28.40 \\
9,20\end{array}$ & $\begin{array}{l}27.96 \\
8.94\end{array}$ & $\begin{array}{l}27.89 \\
8,87\end{array}$ & $\begin{array}{l}27.96 \\
8 ., 86\end{array}$ & $\begin{array}{l}27.96 \\
8.78\end{array}$ & 16 & $\begin{array}{l}288.36 \\
8.76\end{array}$ & $\begin{array}{l}28.13 \\
8.89\end{array}$ & ${ }^{108}$ & 4 & $\begin{array}{l}27.67 \\
8.77\end{array}$ & 60 & & $\begin{array}{l}27.67 \\
8.79\end{array}$ & & & $\begin{array}{l}27.77 \\
8.96\end{array}$ & & & & & & & & $\begin{array}{l}28,06 \\
9 ., 20\end{array}$ & & 77 & $\begin{array}{l}7.65 \\
8.90\end{array}$ & 27.67 \\
\hline MnO & 0.63 & 0.61 & 0.63 & 0.63 & 年 & $\begin{array}{l}0.66 \\
0.66\end{array}$ & o. 0.64 & $\begin{array}{l}0.012 \\
0.72\end{array}$ & $\begin{array}{l}0,000 \\
0.60\end{array}$ & $\begin{array}{l}0.74 \\
0.76\end{array}$ & $\begin{array}{l}0.50 \\
0.59\end{array}$ & 0.74 & 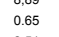 & $\begin{array}{l}0,0.4 \\
0.60\end{array}$ & 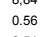 & 0.63 & 0 & $\begin{array}{l}0,040 \\
0.64\end{array}$ & 0.56 & $\begin{array}{l}0,6303 \\
0.63\end{array}$ & 0 & 0 & $\begin{array}{l}0,300 \\
0.59\end{array}$ & 0.63 & 0.62 & 0.60 & 0.06 & & 67 & $\begin{array}{l}0.58 \\
0.58\end{array}$ & 31 & 88 & 0.58 & .63 \\
\hline $\mathrm{CaO}$ & $\begin{array}{l}1,25 \\
102\end{array}$ & ${ }_{1,28}^{1,28}$ & $\begin{array}{l}1,38 \\
08,6\end{array}$ & $\begin{array}{l}1,46 \\
0\end{array}$ & $\begin{array}{l}1,55 \\
105\end{array}$ & $\begin{array}{r}1,68 \\
1007\end{array}$ & $\begin{array}{l}1,99 \\
0\end{array}$ & $\begin{array}{l}2,03 \\
\end{array}$ & $\begin{array}{r}2,25 \\
\end{array}$ & $\begin{array}{r}2,22 \\
\end{array}$ & $\begin{array}{l}2,39 \\
\end{array}$ & $\begin{array}{r}2,46 \\
107\end{array}$ & $\begin{array}{r}2,51 \\
1001\end{array}$ & $\begin{array}{l}2,52 \\
\end{array}$ & $\begin{array}{r}2,51 \\
\end{array}$ & $\begin{array}{r}2,63 \\
\end{array}$ & 2,58 & 2,39 & 2,41 & 2,39 & 2,32 & & 2,20 & 2,17 & & 2,01 & & & 2,05 & & & 2,35 & 2,37 & 2,50 \\
\hline Total & 100.98 & 101.41 & 98.62 & 100.49 & 101.16 & 100.71 & 99.94 & 99.80 & 100.41 & 100.16 & 99.99 & 100.72 & 100.17 & 99.83 & 100.61 & 100.08 & 99.88 & 100.35 & 99.69 & 101.16 & 100.94 & 100.85 & 100.01 & 100.31 & 100.36 & 99.85 & 100.67 & 100.12 & 99.89 & 100.04 & .02 & 100.15 & 99.80 & 99.61 \\
\hline $\mathrm{si}$ & 3,016 & 2,99 & 2,96 & 2,991 & 2,966 & 2,985 & 2,985 & & & & & & 2,949 & 2,958 & & & & & & & & & & & & & & & & & & & & \\
\hline Al & & & & & & & & & & & & & & & & & & & & & & & & & & & & & & & & & & \\
\hline $\mathrm{Fe}$ & 1,852 & 1,850 & 1,878 & 1,845 & 1,838 & 1,824 & 1,808 & 1,808 & 1,79 & 1,806 & 1,8 & 1,8 & 1,8 & 1, & 1,8 & & 1,842 & & 1,7 & 1,79 & & & 1,80 & & & 1,86 & & & 1.81 & & & & 90 & 798 \\
\hline $\mathrm{Mg}$ & 1,003 & 1,032 & 1,0 & 1,046 & 1,1 & 1,0 & 1,031 & $1, \mathrm{C}$ & 1,0 & & 1, & 1,0 & & & 1,6 & & & & 1,0 & & & & & & & & & & & & & & & 037 \\
\hline $\begin{array}{l}\mathrm{Mn} \\
\mathrm{Ca}\end{array}$ & $\begin{array}{l}0.041 \\
0.103\end{array}$ & $\begin{array}{l}0.04 \\
0.105\end{array}$ & $\begin{array}{l}0.042 \\
0.01112\end{array}$ & $\begin{array}{l}0.041 \\
0.012\end{array}$ & $\begin{array}{l}0.045 \\
0.127\end{array}$ & & & & & & & & & & & & & & 0.037 & & & & & & & & & & & & & & & 042 \\
\hline & 0.103 & 0.105 & 0.116 & 0.12 & 0.127 & 0.139 & 0.105 & 0.169 & 0.185 & 0.184 & 0.199 & 0.203 & 0.208 & 0.21 & 0.207 & 0.218 & 0.215 & 0.198 & 0.2 & 0.195 & 0.19 & 0.187 & 0.1 .12 & 0.179 & 0.172 & 0.166 & 0.149 & 0.135 & 0.17 & 0.174 & 0.195 & 0.195 & 0.1966 & 0.208 \\
\hline & 0. & 0. & & & & & & & & & & & & & & & & & 0. & & & & & & & & & & & & & & & 37 \\
\hline Alm & 0.6 & 0.6 & & & 0.4 & & & & & & & & & & & & & & & & & & & & & & & & & & & & & 58 \\
\hline Pyr & 0.33 & 0.34 & 0.34 & 0.34 & 0.36 & 0.3 & 0.34 & 0.34 & & 0.33 & 0 & & 0.33 & 0.33 & & 0.3 & & & & & & & & & & & & & & & & & 34 & 34 \\
\hline $\begin{array}{l}\text { Sps } \\
\text { Grs }\end{array}$ & 0.03 & 0.04 & $\begin{array}{l}0.01 \\
0.04\end{array}$ & 0.04 & & & & 0.06 & & 0.06 & & & 0.07 & & & 0.07 & 0.07 & & 0.07 & 0.07 & & 0.06 & & 0.06 & 0.6 & & 0.05 & 0.04 & 0.06 & 0.06 & 0.06 & 0.06 & 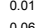 & $\begin{array}{l}0.01 \\
0.07\end{array}$ \\
\hline Grs & 0.03 & 0.04 & 0.04 & 0.04 & 0.04 & 0.05 & 0.05 & 0.06 & 0.06 & 0.06 & 0.06 & 0.07 & 0.01 & 0.07 & 0.07 & $0.07 /$ & 0.07 & 0.06 & 0.07 & 0.01 & 0.06 & 0.00 & 0.06 & 0.06 & 0.00 & 0.05 & 0.05 & 0.04 & 0.06 & 0.06 & 0.06 & 0.06 & 0.06 & 0.07 \\
\hline
\end{tabular}




\begin{tabular}{|c|c|c|c|c|c|c|c|c|c|c|c|c|c|c|c|c|c|c|c|c|c|c|c|c|c|c|c|c|c|c|c|c|c|c|}
\hline $\begin{array}{l}\text { rofiflina } \\
\text { Pat } \\
\text { Dist }\end{array}$ & $\begin{array}{r}1 \\
1 \\
0\end{array}$ & $\begin{array}{r}2 \\
20 \\
\end{array}$ & $\begin{array}{c}3 \\
40 \\
\end{array}$ & $\begin{array}{c}4 \\
60 \\
\end{array}$ & $\begin{array}{l}5 \\
80 \\
8\end{array}$ & $\begin{array}{c}6 \\
100 \\
\end{array}$ & $\begin{array}{c}7 \\
120 \\
\end{array}$ & $\begin{array}{c}8 \\
140 \\
\end{array}$ & $\begin{array}{c}9 \\
160 \\
\end{array}$ & $\begin{array}{c}10 \\
180 \\
\end{array}$ & $\begin{array}{l}11 \\
200 \\
20\end{array}$ & $\begin{array}{r}12 \\
220 \\
2\end{array}$ & $\begin{array}{r}13 \\
240 \\
240\end{array}$ & $\begin{array}{r}14 \\
260 \\
\end{array}$ & $\begin{array}{l}15 \\
280 \\
28\end{array}$ & $\begin{array}{c}16 \\
300 \\
300\end{array}$ & $\begin{array}{r}17 \\
320 \\
\end{array}$ & $\begin{array}{r}18 \\
340 \\
\end{array}$ & $\begin{array}{r}19 \\
360 \\
\end{array}$ & $\begin{array}{l}20 \\
380 \\
\end{array}$ & $\begin{array}{l}21 \\
400 \\
\end{array}$ & $\begin{array}{r}22 \\
420 \\
\end{array}$ & $\begin{array}{l}23 \\
440 \\
440\end{array}$ & $\begin{array}{r}24 \\
460 \\
\end{array}$ & $\begin{array}{r}25 \\
480 \\
\end{array}$ & $\begin{array}{l}26 \\
500 \\
50\end{array}$ & $\begin{array}{r}27 \\
520 \\
\end{array}$ & $\begin{array}{r}28 \\
540 \\
\end{array}$ & $\begin{array}{l}29 \\
560 \\
\end{array}$ & $\begin{array}{l}30 \\
580 \\
580\end{array}$ & $\begin{array}{l}31 \\
600 \\
60\end{array}$ & $\begin{array}{r}32 \\
620 \\
\end{array}$ & $\begin{array}{r}33 \\
640 \\
640\end{array}$ & $\begin{array}{l}34 \\
660\end{array}$ \\
\hline $\mathrm{SiO} 2$ & 38.58 & 37.97 & 38.08 & 38.87 & 38.64 & 38.86 & 38.10 & 38.53 & 37.96 & 38.12 & 38.45 & 38.25 & 38.00 & 38.65 & 38.67 & 38.92 & 38.07 & 38.02 & 39.02 & 38.83 & 38.11 & 38.70 & 38.58 & 38.43 & 38.58 & 38.15 & 38.02 & 38.47 & 37.45 & 39.28 & 38.01 & 38.20 & 38.61 & 39.02 \\
\hline A1203 & 21.90 & 21.95 & 21.89 & 21.96 & 21.75 & 21.64 & 21.83 & 21.89 & & 22,12 & 21.80 & 21.73 & 21.81 & 21.87 & 21.79 & 21.71 & 21.78 & 21.81 & 21.82 & 21.55 & 21.75 & 21.72 & 21.74 & 21.81 & 21.84 & 21.80 & 21.77 & 21.80 & 21.30 & & 21.81 & 2,05 & 21.87 & 22,08 \\
\hline FeO & 27.73 & 27.20 & 27.60 & 27.71 & 27.28 & 27.56 & 27.58 & 27.36 & 26.75 & 27.50 & 27.64 & 26.76 & 27,01 & 27.14 & 27.15 & 26.98 & 27,08 & 26.51 & 26.81 & 26.83 & 26.43 & 26.54 & 26.46 & 26.31 & 26.19 & 26.78 & 26.23 & 26.82 & 26.69 & 26.55 & 27,02 & 26.65 & 27,05 & 26.92 \\
\hline $\mathrm{MgO}$ & 10,16 & 10,27 & $\begin{array}{l}10,17 \\
0,77\end{array}$ & $\begin{array}{l}10,11 \\
\end{array}$ & $\begin{array}{l}9,95 \\
0.59\end{array}$ & 10,11 & 10,04 & $\begin{array}{l}9,93 \\
0,94\end{array}$ & 9,81 & 9,85 & 9,75 & 9,53 & 9.51 & $\begin{array}{l}9,53 \\
0.56\end{array}$ & 9,51 & 9,51 & $\begin{array}{l}9,35 \\
0.56\end{array}$ & 9,27 & 9,13 & 9,29 & 9,10 & 9,25 & 9,20 & 9,14 & 9,34 & 9,28 & 9,27 & 9,46 & 9,32 & 9,49 & 9,60 & 9,70 & 9,75 & 9,81 \\
\hline Mno & 0.61 & 0.61 & $\begin{array}{l}0.73 \\
0\end{array}$ & $\begin{array}{l}0.65 \\
1.92\end{array}$ & $\begin{array}{l}0.58 \\
1.98\end{array}$ & 0.64 & $\begin{array}{l}0.70 \\
151\end{array}$ & $\begin{array}{l}0.64 \\
1.15\end{array}$ & 0.66 & 0.69 & $\begin{array}{l}0.68 \\
206\end{array}$ & $\begin{array}{l}0.66 \\
225\end{array}$ & $\begin{array}{l}0.60 \\
2.28\end{array}$ & $\begin{array}{l}0.56 \\
2.53\end{array}$ & $\begin{array}{l}0.56 \\
2.62\end{array}$ & $\begin{array}{l}0.64 \\
2704\end{array}$ & $\begin{array}{l}0.65 \\
285\end{array}$ & $\begin{array}{l}0.69 \\
2\end{array}$ & $\begin{array}{l}0.53 \\
2\end{array}$ & $\begin{array}{l}0.65 \\
31\end{array}$ & $\begin{array}{l}0.62 \\
3.31\end{array}$ & 0.61 & $\begin{array}{l}0.59 \\
3.54\end{array}$ & $\begin{array}{l}0.64 \\
392\end{array}$ & $\begin{array}{l}0.52 \\
3.9\end{array}$ & $\begin{array}{l}0.57 \\
3.372\end{array}$ & 0.71 & 0.56 & 0.57 & $\begin{array}{l}0.59 \\
.797\end{array}$ & 0.58 & 0.58 & 61 & $\begin{array}{l}0.59 \\
0.94\end{array}$ \\
\hline $\begin{array}{l}\text { cao } \\
\text { Total }\end{array}$ & $\begin{array}{l}1,14 \\
100.12\end{array}$ & $\begin{array}{l}1,12 \\
99.11\end{array}$ & $\begin{array}{l}1,20 \\
99.67\end{array}$ & $\begin{array}{c}1,19 \\
100.59\end{array}$ & $\begin{array}{l}1,29 \\
99.48\end{array}$ & $\begin{array}{l}1,40 \\
100.21\end{array}$ & $\begin{array}{l}1,1,51 \\
99.77\end{array}$ & $\begin{array}{l}1,1,5 \\
99.99\end{array}$ & $\begin{array}{r}1,73 \\
98.68\end{array}$ & $\begin{array}{l}1,84 \\
100.11\end{array}$ & $\begin{array}{c}2,06 \\
100.39\end{array}$ & $\begin{array}{l}2,25 \\
99.17\end{array}$ & $\begin{array}{l}\begin{array}{l}2,28 \\
99.21\end{array}\end{array}$ & $\begin{array}{c}2,53 \\
105.27\end{array}$ & $\begin{array}{r}2,62 \\
100.29\end{array}$ & $\begin{array}{c}2,70 \\
100.45\end{array}$ & $\begin{array}{c}2,844 \\
99,79\end{array}$ & $\begin{array}{c}2,988 \\
99.28\end{array}$ & $\begin{array}{r}2,99 \\
100.29\end{array}$ & $\begin{array}{c}3,11 \\
100.26\end{array}$ & $\begin{array}{l}3,13 \\
99.14\end{array}$ & $\begin{array}{l}3,12 \\
99995\end{array}$ & $\begin{array}{l}3,24 \\
9.9 .81\end{array}$ & $\begin{array}{l}3,29 \\
99,62\end{array}$ & $\begin{array}{l}3,19 \\
99.66\end{array}$ & $\begin{array}{l}3,02 \\
9.959\end{array}$ & $\begin{array}{l}3,07 \\
99.97\end{array}$ & $\begin{array}{r}2,97 \\
1000.08\end{array}$ & & $\begin{array}{r}2,77 \\
1000.45\end{array}$ & $\begin{array}{l}2,773 \\
99975\end{array}$ & & $\begin{array}{r}2,37 \\
100.26\end{array}$ & $\begin{array}{r}2,24 \\
10006\end{array}$ \\
\hline $\mathrm{Si}$ & 2,968 & 2,949 & 2,948 & 2,976 & 2,987 & 2,987 & 2,949 & 2,969 & 2,961 & 2,940 & 2,960 & 2,972 & 2,956 & 2,972 & 2,974 & 2,986 & 2,950 & & 2,996 & 2.988 & & & & 2973 & & & 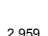 & & & & & & & 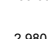 \\
\hline Al & & & & & & & & & & & & & & & & & & & & & $\begin{array}{l}2,300 \\
1,995\end{array}$ & & & & & & & & & & & & $\begin{array}{l}2,968 \\
1,981\end{array}$ & $\begin{array}{l}2,990 \\
1,988 \\
\end{array}$ \\
\hline $\mathrm{Fe}$ & 1,78 & 1,76 & 1,7 & 1,7 & 1,7 & 1,7 & 1,7 & 1,7 & & & 1,7 & & & 1,7 & & & & & & $1,7$. & & & & & & & & & & & & & 739 & 1,720 \\
\hline $\mathrm{Mg}$ & 1,165 & 1,189 & 1,174 & 1,1 & & & 1,1 & 1,14 & & 1,1 & 1,119 & & & & & & & 1,07 & & 1,066 & & & & & & & & & & & 1,109 & & 1,117 & 1,117 \\
\hline $\mathrm{Mn}$ & 0.039 & 0.04 & 0.048 & $\begin{array}{l}0.042 \\
0.04\end{array}$ & 0.038 & 0.041 & 0.046 & 0.041 & 0.044 & 0.045 & 0.044 & 0.043 & $\begin{array}{l}0.039 \\
0\end{array}$ & 0.036 & 0.036 & 0.041 & 0.043 & 0.046 & $\begin{array}{l}0.035 \\
\end{array}$ & 0.043 & 0.041 & 0.04 & 0.038 & 0.042 & 0.034 & 0.037 & 0.047 & 0.036 & 0.038 & 0.038 & 0.038 & 0.038 & 0.04 & 0.038 \\
\hline $\mathrm{Ca}$ & 0.094 & 0.093 & 0.1 & 0.106 & 0.107 & 0.115 & 0.126 & 0.136 & 0.144 & 0.152 & 0.17 & 0.187 & 0.19 & 0.208 & 0.216 & 0.222 & 0.236 & 0.248 & 0.246 & 0.256 & 0.261 & 0.258 & 0.268 & 0.273 & 0.263 & 0.251 & 0.256 & 0.245 & 0.241 & 0.227 & 0.226 & 0.207 & 0.195 & 0.183 \\
\hline MgRat & 0.40 & & 0.40 & 0.3 & 0.39 & 0.40 & 0. & 0.33 & 0.4 & & 0.39 & 0.3 & 0.39 & & 0.38 & 0.39 & & 0.3 & 0.38 & & 0.36 & 0.38 & 0.38 & & 36 & & & & 0.38 & & 0.39 & 0.39 & & 0.39 \\
\hline $\mathrm{Am}$ & 0.58 & 0.57 & 0.58 & 0. & 0.58 & 0.57 & & 0.5 & & & & & & & & & & & & & & & & & & & & & & & & & & \\
\hline 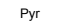 & 0.3 & 0.39 & 0.38 & 0.3 & 0.3 & 0.38 & 0. & 0.3 & 0.3 & 0. & 0.3 & 0.3 & 0. & 0.3 & 0.3 & & 0.3 & 0.3 & 0 & 0. & 0.3 & & 0 & & & 0. & & & & & & & & 37 \\
\hline Sps & 0.01 & 0.01 & 0.02 & 0.6 & & 0.01 & 0.0 & 0.01 & 0.01 & 0. & 0.01 & 0.01 & 0.01 & 0.0 & 0.01 & 0.01 & 0. & 0.02 & 0.0 & 0. & 0.01 & 0.6 & 0 & 0.01 & & 0. & 0.6 & & & & 01 & & 01 & 01 \\
\hline Grs & 0.03 & 0.03 & 0.03 & 0.03 & 0.04 & 0.04 & 0.04 & 0.04 & 0.05 & 0.05 & 0.06 & 0.06 & 0.06 & 0.07 & 0.07 & 0.07 & 0.08 & 0.08 & 0.08 & 0.08 & 0.09 & 0.08 & 0.09 & 0.09 & 0.09 & 0.08 & 0.08 & 0.08 & 0.08 & 0.07 & 0.07 & 0.07 & 0.06 & 0.06 \\
\hline
\end{tabular}

\begin{tabular}{|c|c|c|c|c|c|c|c|c|c|c|c|c|c|c|c|c|c|c|c|c|c|c|c|c|c|c|c|c|c|c|c|c|c|c|}
\hline $\begin{array}{c}\text { Profill lagrn } \\
\text { Pt } \\
\text { Dist } \\
\end{array}$ & $\begin{array}{r}1 \\
1 \\
0\end{array}$ & $\begin{array}{r}2 \\
26 \\
\end{array}$ & $\begin{array}{c}3 \\
51 \\
51\end{array}$ & $\begin{array}{c}4 \\
77 \\
77\end{array}$ & $\begin{array}{c}5 \\
102 \\
\end{array}$ & $\begin{array}{c}7 \\
153 \\
\end{array}$ & $\begin{array}{c}8 \\
178 \\
\end{array}$ & $\begin{array}{c}9 \\
204 \\
204\end{array}$ & $\begin{array}{c}10 \\
229 \\
229\end{array}$ & $\begin{array}{l}11 \\
254\end{array}$ & $\begin{array}{c}12 \\
280 \\
280\end{array}$ & $\begin{array}{c}13 \\
306 \\
30\end{array}$ & $\begin{array}{r}15 \\
357 \\
\end{array}$ & $\begin{array}{r}16 \\
382 \\
\end{array}$ & $\begin{array}{c}17 \\
407\end{array}$ & $\begin{array}{c}18 \\
433 \\
433\end{array}$ & $\begin{array}{r}19 \\
458 \\
\end{array}$ & $\begin{array}{r}20 \\
484 \\
\end{array}$ & $\begin{array}{l}21 \\
509 \\
5\end{array}$ & $\begin{array}{r}22 \\
534 \\
\end{array}$ & $\begin{array}{c}23 \\
560 \\
560\end{array}$ & $\begin{array}{l}24 \\
585 \\
\end{array}$ & $\begin{array}{l}26 \\
636 \\
\end{array}$ & $\begin{array}{l}27 \\
661 \\
6\end{array}$ & $\begin{array}{c}28 \\
686 \\
68\end{array}$ & $\begin{array}{c}29 \\
712 \\
\end{array}$ & $\begin{array}{l}30 \\
737 \\
\end{array}$ & $\begin{array}{c}31 \\
762 \\
762\end{array}$ & $\begin{array}{r}32 \\
788 \\
\end{array}$ & $\begin{array}{c}33 \\
813 \\
813\end{array}$ & $\begin{array}{l}34 \\
839 \\
839\end{array}$ & $\begin{array}{l}36 \\
889 \\
889\end{array}$ & $\begin{array}{r}37 \\
915 \\
\end{array}$ & $\begin{array}{c}39 \\
966\end{array}$ \\
\hline $\mathrm{SiO} 2$ & 38.68 & 39.07 & 38.44 & 39.02 & 38.81 & 39.16 & 38.55 & 38.64 & 38.22 & 38.37 & 38.70 & 38.59 & 38.87 & 38.86 & 38.49 & 38.49 & 38.61 & 38.14 & 38.51 & 38.40 & 38.98 & 38.42 & 39.31 & 38.71 & 39.30 & 38.99 & 38.58 & 39.04 & 39.05 & 38.87 & 39.18 & 38.67 & 38.42 & 38.70 \\
\hline A1203 & 21.80 & 21.88 & 22,01 & 21.94 & 22,12 & 22.14 & 21.91 & 21.91 & 21.90 & 22,11 & 22,03 & 22.14 & 22,08 & 22.22 & 21.98 & 22.18 & 22.15 & 22.00 & 21.92 & 21.99 & 21.81 & 22,06 & 22,04 & 22,08 & 22,06 & 22.26 & 22,07 & 21.86 & 22,10 & 22,07 & 22.17 & 22.29 & 21.99 & 22,11 \\
\hline $\mathrm{FeO}$ & 28.65 & 28,04 & 27.73 & 27.37 & 27.49 & 26.93 & 27,02 & 26.94 & 26.38 & 26.42 & 26.52 & 26.43 & 26.25 & 25.96 & 26.33 & 25.71 & 26.22 & 25.85 & 26.17 & 25.86 & 25.83 & 25.72 & 25.89 & 25.41 & 25.75 & 25.42 & 25.62 & 25.78 & 25.46 & 25.49 & 25.72 & 26.31 & 25.98 & 25.75 \\
\hline MgO & $\begin{array}{l}9,30 \\
0,07\end{array}$ & $\begin{array}{l}9,68 \\
0.64\end{array}$ & $\begin{array}{l}9,79 \\
0.57\end{array}$ & $\begin{array}{l}9,85 \\
0.05\end{array}$ & $\begin{array}{l}9,83 \\
0.67\end{array}$ & $\begin{array}{l}9,90 \\
053\end{array}$ & $\begin{array}{l}9,87 \\
0.56\end{array}$ & $\begin{array}{l}9,96 \\
0,05\end{array}$ & 9,86 & 9,88 & $\begin{array}{l}9,89 \\
058\end{array}$ & 9,70 & $\begin{array}{l}9,96 \\
\end{array}$ & 9,79 & 10,09 & 10,09 & $\begin{array}{l}10,20 \\
\end{array}$ & $\begin{array}{l}10,26 \\
0,5\end{array}$ & 10,14 & $\begin{array}{l}10,23 \\
\end{array}$ & 10,04 & ,03 & 9,95 & 9,93 & & 9,97 & .11 & 10,11 & 10,10 & 10,26 & 10,32 & 10,68 & 10,89 & 10,93 \\
\hline Mno & 0.57 & 0.64 & $\begin{array}{l}0.57 \\
1.53\end{array}$ & $\begin{array}{l}0.55 \\
1.55\end{array}$ & $\begin{array}{l}.0 .67 \\
1.55\end{array}$ & $\begin{array}{l}0.53 \\
2.25\end{array}$ & $\begin{array}{l}0.56 \\
2.60\end{array}$ & $\begin{array}{l}0.52 \\
2.22\end{array}$ & $\begin{array}{l}0.46 \\
261\end{array}$ & 0.45 & $\begin{array}{l}0.58 \\
2.57\end{array}$ & $\begin{array}{l}0.49 \\
278\end{array}$ & $\begin{array}{l}0.52 \\
2.74\end{array}$ & $\begin{array}{l}0.51 \\
2.57\end{array}$ & $\begin{array}{l}0.43 \\
270\end{array}$ & $\begin{array}{l}0.57 \\
2.27\end{array}$ & $\begin{array}{l}0.46 \\
2.67\end{array}$ & $\begin{array}{l}0.50 \\
2.73\end{array}$ & $\begin{array}{l}0.47 \\
2.78\end{array}$ & $\begin{array}{l}0.47 \\
2.27\end{array}$ & $\begin{array}{l}0.44 \\
2.25\end{array}$ & $\begin{array}{l}0.50 \\
\end{array}$ & $\begin{array}{l}0.53 \\
3.31\end{array}$ & 19 & 0.55 & 0.46 & 0.50 & 0.45 & 0.53 & 0.42 & .42 & 0.42 & 0.49 & 0.47 \\
\hline $\begin{array}{l}\text { cao } \\
\text { Total }\end{array}$ & $\begin{array}{l}1,18 \\
100.27\end{array}$ & $\begin{array}{c}1,141 \\
100.72\end{array}$ & $\begin{array}{c}1,53 \\
100.07\end{array}$ & $\begin{array}{c}1,165 \\
100.38\end{array}$ & $\begin{array}{l}1,185 \\
100.77\end{array}$ & $\begin{array}{c}2,215 \\
100.80\end{array}$ & $\begin{array}{c}2,40 \\
100.30\end{array}$ & $\begin{array}{c}2,42 \\
100.41\end{array}$ & $\begin{array}{l}2,261 \\
99.44\end{array}$ & $\begin{array}{l}2,72 \\
99.95\end{array}$ & $\begin{array}{l}2,75 \\
100.47\end{array}$ & $\begin{array}{c}2,78 \\
100.12\end{array}$ & $\begin{array}{c}2,74 \\
100.42\end{array}$ & $\begin{array}{c}2,75 \\
100.09\end{array}$ & $\begin{array}{c}2,70 \\
100.01\end{array}$ & $\begin{array}{l}2,77 \\
9.991\end{array}$ & $\begin{array}{c}2.67 \\
100.31\end{array}$ & $\begin{array}{c}2,73 \\
99.49\end{array}$ & $\begin{array}{l}2,78 \\
9.9 .99\end{array}$ & $\begin{array}{c}2,77 \\
99.72\end{array}$ & $\begin{array}{c}2,955 \\
109.04\end{array}$ & $\begin{array}{r}2,99 \\
99.72\end{array}$ & $\begin{array}{c}3,11 \\
100.83\end{array}$ & $\begin{array}{l}3,21 \\
9.9 .83\end{array}$ & $\begin{array}{c}3,19 \\
100.92\end{array}$ & $\begin{array}{c}3.23 \\
100.33\end{array}$ & $\begin{array}{c}3,17 \\
100.05\end{array}$ & $\begin{array}{c}3.10 \\
100.34\end{array}$ & $\begin{array}{r}2,96 \\
100.20\end{array}$ & $\begin{array}{r}2,89 \\
100.01\end{array}$ & $\begin{array}{c}2,73 \\
100.54\end{array}$ & $\begin{array}{c}2,14 \\
100.52\end{array}$ & $\begin{array}{l}1,99 \\
99.76\end{array}$ & $\begin{array}{l}1,68 \\
99.63\end{array}$ \\
\hline $\mathrm{Si}$ & 2,984 & 2,991 & 2,963 & 2,990 & 2,968 & 2,984 & 2,962 & 2,964 & 2,957 & 2,952 & 2,964 & 2,963 & 2,972 & 2,976 & 2,958 & 2,958 & 2,956 & 2,944 & 2,960 & 2,956 & 2,987 & 2,957 & 2,989 & 2,971 & 2,984 & 2.974 & 2.958 & 2.983 & 2,982 & 2.974 & 2.981 & 2.950 & 2,951 & 2,967 \\
\hline Al & 1,982 & 1,974 & 2,000 & 1,981 & 1,993 & 1,988 & 1,984 & 1,981 & 1,997 & 2,005 & 1,988 & 2,004 & 1,989 & 2,006 & 1,991 & 2,008 & 1,998 & 2,002 & 1,985 & $\begin{array}{l}1,905 \\
1,995\end{array}$ & $\begin{array}{l}1,1970 \\
1,0\end{array}$ & 2,001 & 1,975 & 1,997 & 1,974 & 2,002 & 1,995 & 1,968 & 1,989 & 1,990 & 1,988 & 2,004 & 1,991 & 1,998 \\
\hline $\mathrm{Fe}$ & 1,848 & & & 1,753 & 1,758 & & & 1,728 & 1,707 & & 1,698 & 1,697 & & 1,663 & 1,693 & & & 1,669 & & & & & & & & & & & & & & & 1,669 & 1,652 \\
\hline Mg & 1,069 & 1,104 & 1,124 & 1,125 & 1,120 & 1,125 & 1,130 & $\begin{array}{l}1,139 \\
\end{array}$ & 1,137 & 1,134 & 1,128 & 1,110 & 1,136 & 1,118 & 1,155 & 1,156 & 1,164 & 1,181 & 1,161 & 1,174 & 1,146 & 1,151 & 1,128 & 1,136 & 1,142 & 1,134 & 1,156 & 1,151 & 1,150 & 1,170 & 1,171 & 1,214 & 1,247 & 1,249 \\
\hline $\mathrm{Mn}$ & 0.037 & 0.041 & 0.037 & 0.036 & 0.043 & 0.034 & 0.036 & 0.034 & 0.03 & 0.029 & 0.038 & 0.032 & 0.034 & 0.033 & 0.028 & 0.037 & 0.03 & 0.033 & 0.03 & 0.03 & 0.028 & 0.032 & 0.034 & 0.032 & 0.035 & 0.03 & 0.033 & 0.029 & 0.034 & 0.027 & 0.027 & 0.027 & 0.032 & 0.03 \\
\hline $\mathrm{Ca}$ & 0.106 & 0.115 & 0.126 & 0.136 & 0.152 & 0.175 & 0.197 & 0.199 & 0.217 & 0.224 & 0.226 & 0.228 & 0.224 & 0.226 & 0.222 & 0.228 & 0.219 & 0.226 & 0.229 & 0.228 & 0.242 & 0.247 & 0.253 & 0.264 & 0.259 & 0.264 & 0.26 & 0.254 & 0.242 & 0.237 & 0.222 & 0.175 & 0.164 & 0.138 \\
\hline MgRat & 0.37 & 0.38 & 0.39 & 0.39 & 0.39 & 0.40 & 0.39 & 0.40 & 0.40 & 0.40 & 0.40 & 0.40 & 0.40 & 0.40 & 0.41 & 0.41 & 0.41 & 0.41 & 0.41 & 0.41 & 0.41 & 0.41 & 0.41 & 0.41 & 0.41 & 0.41 & 0.41 & 0.41 & 0.41 & 0.42 & 0.42 & 0.42 & 143 & 0.43 \\
\hline $\mathrm{Alm}$ & 0.60 & 0.59 & 0.58 & 0.58 & 0.57 & 0.56 & 0.56 & 0.56 & 0.55 & 0.55 & 0.55 & 0.55 & 0.55 & 0.55 & 0.55 & 0.54 & 0.5 & 0.54 & 0.54 & & 0.54 & 0.54 & & & 0.5 & & & 0. & & & & & & 0.54 \\
\hline Pyr & 0.35 & 0.36 & 0.37 & 0.37 & 0.37 & 0.37 & 0.37 & 0.37 & 0.37 & 0.37 & 0.37 & 0.36 & 0.37 & 0.37 & 0.37 & 0.38 & 0.38 & 0.38 & 0.37 & 0.38 & 0.37 & 0.37 & 0.3 & 0.37 & 0.37 & 0.3 & 0.37 & 0.3 & & & & & & 0.41 \\
\hline Sps & 0.01 & 0.01 & 0.01 & 0.01 & 0.01 & 0.01 & 0.01 & 0.01 & 0.01 & 0.01 & 0.01 & 0.01 & 0.01 & 0.01 & 0.01 & 0.01 & 0.01 & 0.01 & 0.01 & 0.01 & 0.01 & 0.01 & 0.01 & 0.01 & 0.01 & 0.01 & 0.01 & 0.01 & & 0.01 & 0.01 & & 0.01 & 0.01 \\
\hline Grs & 0.04 & 0.04 & 0.04 & 0.04 & 0.05 & 0.06 & 0.06 & 0.06 & 0.07 & 0.07 & 0.07 & 0.07 & 0.07 & 0.07 & 0.07 & 0.07 & 0.07 & 0.07 & 0.07 & 0.07 & 0.08 & 0.08 & 0.08 & 0.09 & 0.08 & 0.09 & 0.08 & 0.08 & 0.08 & 0.08 & 0.07 & 0.06 & 0.05 & 0.05 \\
\hline $\begin{array}{r}\text { profil garn } \\
\text { Pt }\end{array}$ & 1 & 2 & 3 & 4 & 5 & & 7 & 8 & & 10 & 11 & 12 & 13 & 14 & 15 & 16 & & 18 & 19 & & & & & & & & & & & & & & & \\
\hline Dist & 0 & 20 & 41 & 61 & 81 & 101 & 121 & 142 & 162 & 182 & 202 & 223 & 243 & 263 & 283 & 304 & 324 & $\begin{array}{l}344 \\
344\end{array}$ & 364 & 385 & 405 & $\begin{array}{l}22 \\
425\end{array}$ & 1221 & $\begin{array}{l}1242 \\
1242\end{array}$ & 1263 & 1284 & 1305 & 1326 & 1347 & 1368 & 1389 & 1410 & 1430 & 1451 \\
\hline Sif & 38.69 & & & 38 & 38. & & & 38. & & & 38 & & & & & & & & & & & & & & & & & & & & & & 93 & 10 \\
\hline & 22,04 & 22,10 & 22.21 & 22.25 & 21.85 & 22.23 & 22. & 21.99 & 22.31 & 22. & 21.96 & & 21. & 21.9 & & 21.95 & & $21 .: 5$ & 22,1 & & 21. & 21.9 & & & & & & & & & & & & 22,01 \\
\hline $\mathrm{FeO}$ & 28.93 & 29.38 & 28.86 & 28.97 & 28.78 & 28.78 & 29,10 & 28.74 & 28.86 & 28 & 28.78 & 29,04 & 29,06 & 28.97 & 29,05 & 29 & 29,06 & 28.8 & & 29.24 & 29 , & 29.13 & & & 28.92 & 28.7 & 29 & 28.99 & 28.87 & & 28.97 & 9.13 & 29,04 & 29.02 \\
\hline & 8,98 & 9,10 & 9,16 & 9,19 & 9,00 & 9,13 & 9,24 & 9,00 & & & 8,98 & & & 9,14 & & & & & & & & & & & & & & & & & & & & \\
\hline Mno & 0.65 & 0.64 & 0.64 & 0.72 & 0.69 & 0.66 & 0.69 & 0.68 & 0.61 & 0.66 & 0.64 & 0.65 & 0.59 & 0.61 & 0.68 & 0.66 & 0.67 & 0.70 & 0.69 & 0.62 & 0.69 & 0.67 & 0.75 & 0.69 & 0.64 & 0.71 & 0. & 0.65 & 0.69 & & 0.65 & 69 & 11 & 0.75 \\
\hline $\begin{array}{c}\text { caa } \\
\text { Totat }\end{array}$ & $\begin{array}{l}1,11 \\
10040\end{array}$ & $\begin{array}{c}1,33 \\
101,1\end{array}$ & $\begin{array}{c}1,35 \\
1011\end{array}$ & $\begin{array}{c}1,44 \\
1011\end{array}$ & $\begin{array}{c}1,41 \\
10026\end{array}$ & $\begin{array}{c}1,48 \\
10065\end{array}$ & $\begin{array}{c}1,56 \\
10124\end{array}$ & $\begin{array}{c}1,63 \\
10606\end{array}$ & $\begin{array}{c}1,64 \\
1008\end{array}$ & $\begin{array}{c}1,65 \\
10060\end{array}$ & $\begin{array}{c}1,68 \\
1009\end{array}$ & $\begin{array}{l}1,65 \\
1059\end{array}$ & $\begin{array}{l}1,70 \\
1004\end{array}$ & $\begin{array}{c}1,61,61 \\
10069\end{array}$ & $\begin{array}{c}1,61 \\
101069\end{array}$ & $\begin{array}{c}1,58 \\
1087\end{array}$ & $\begin{array}{c}1,50 \\
100111\end{array}$ & $\begin{array}{c}1,51 \\
1005\end{array}$ & $\begin{array}{c}1,46 \\
1000\end{array}$ & $\begin{array}{l}1,44 \\
10089\end{array}$ & $\begin{array}{c}1,37 \\
100\end{array}$ & $\begin{array}{c}1,48 \\
10088\end{array}$ & $\begin{array}{c}1,48 \\
10103\end{array}$ & ${ }_{1}^{10066}$ & $\begin{array}{c}1,50 \\
10011\end{array}$ & $\begin{array}{c}1,47 \\
10078\end{array}$ & $\begin{array}{c}1,49 \\
10125\end{array}$ & $\begin{array}{l}1,46 \\
10072\end{array}$ & $\begin{array}{c}1,47 \\
10099\end{array}$ & $\begin{array}{c}1,48 \\
10140\end{array}$ & $\begin{array}{l}1.49 \\
10134\end{array}$ & $\begin{array}{c}1,43 \\
1009\end{array}$ & $\begin{array}{c}1,48 \\
1,101\end{array}$ & $\begin{array}{c}1,50 \\
1005\end{array}$ \\
\hline & & & & & & & & & & & 100.93 & & & & & & & & & 100.89 & 100.50 & 100.88 & 101.03 & & 101.13 & 100.78 & 100.25 & 100.72 & 100.99 & 101.40 & 101.34 & 100.93 & 101.15 & 101.56 \\
\hline Si & & & & & & & & & & & & & & & & & & & & & & & & & & & & & & & & & & 2,983 \\
\hline $\mathrm{Al}$ & 2,00 & 2,0 & 2,0 & 2,0 & & & & & & & & & & & & & & & & & & & & & & & & & & & & & & \\
\hline $\mathrm{Fe}$ & 1,86 & 1,88 & 1,847 & 1,8 & & 1,8 & & & & & & & & & & & 1,8 & & & & & & 1. & & & & & & & & & & & 1,851 \\
\hline Mg & 1,032 & 1,041 & 1,045 & 1,05 & 1,03 & 1,04 & 1,0 & 1,0 & 1,03 & 1,0 & 1,0 & & 1,6 & 1,0 & & & & & & & & & & & & & & & & & & & & 1.043 \\
\hline $\mathrm{Mn}$ & 0.042 & 0.041 & 0.041 & 0.047 & $\begin{array}{l}0.045 \\
0.11\end{array}$ & 0.043 & 0.045 & $\begin{array}{l}0.045 \\
0.125\end{array}$ & $\begin{array}{l}0.039 \\
0.129\end{array}$ & 0.043 & 0.042 & $\begin{array}{l}0.042 \\
0.132\end{array}$ & 0.039 & $\begin{array}{l}0.04 \\
0.132\end{array}$ & 0.044 & & 0.044 & & & 0.041 & 0.045 & & 0.049 & 0.045 & & & & 0.043 & & 0.045 & 0.042 & $\begin{array}{l}0.045 \\
0.011\end{array}$ & 0.046 & 0.048 \\
\hline ca & 0.092 & 0.109 & 0.11 & 0.119 & 0.117 & 0.122 & 0.128 & 0.135 & 0.135 & 0.137 & 0.138 & 0.136 & 0.141 & 0.133 & 0.133 & 0.13 & 0.123 & 0.125 & 0.12 & 0.119 & 0.114 & 0.122 & 0.122 & 0.12 & 0.123 & 0.121 & 0.123 & 0.121 & 0.121 & 0.121 & 0.122 & 0.118 & 0.122 & 0.123 \\
\hline MgRat & & & 0. & & & & & & & & & & & & & & & & & & & & & & & & & & & & & 0.36 & & 36 \\
\hline Alm & 0.6 & 0.6 & 0.6 & 0.6 & 0.6 & 0.6 & & 0.6 & & & & & & & & & & & & & & & & & & & & & & & & & & 60 \\
\hline $\begin{array}{l}\text { Pyr } \\
\text { sps }\end{array}$ & $\begin{array}{l}0.34 \\
0.01\end{array}$ & $\begin{array}{l}0.34 \\
0.01\end{array}$ & $\begin{array}{l}0.34 \\
0.01\end{array}$ & $\begin{array}{l}0.34 \\
0.02\end{array}$ & $\begin{array}{l}0.34 \\
0.02\end{array}$ & $\begin{array}{l}0.34 \\
0.01\end{array}$ & $\begin{array}{l}0.34 \\
0.02\end{array}$ & $\begin{array}{l}0.34 \\
0.02\end{array}$ & $\begin{array}{l}.0 .34 \\
0.01\end{array}$ & $\begin{array}{l}0.34 \\
0.01\end{array}$ & $\begin{array}{l}0.34 \\
0.01\end{array}$ & $\begin{array}{l}0.34 \\
0.01\end{array}$ & $\begin{array}{l}0.34 \\
0.01\end{array}$ & $\begin{array}{l}0.34 \\
0.01\end{array}$ & $\begin{array}{l}.0 .34 \\
0.01\end{array}$ & $\begin{array}{l}0.33 \\
0.01\end{array}$ & $\begin{array}{l}0.34 \\
0.01\end{array}$ & $\begin{array}{l}0.3 \\
0.8\end{array}$ & $\begin{array}{l}0.33 \\
0.01\end{array}$ & $\begin{array}{l}0 . \\
0 . \\
0 .\end{array}$ & & $\begin{array}{l}0.34 \\
0.01\end{array}$ & & & & $\begin{array}{l}0 \\
0 \\
0\end{array}$ & & & 32 & 28 & $\begin{array}{l}34 \\
01\end{array}$ & $\begin{array}{l}34 \\
02\end{array}$ & $\begin{array}{l}34 \\
02\end{array}$ & $\begin{array}{l}0.34 \\
0.02\end{array}$ \\
\hline $\begin{array}{l}\text { pss } \\
\text { Grs }\end{array}$ & $\begin{array}{l}0.01 \\
0.03\end{array}$ & $\begin{array}{l}0.01 \\
0.04\end{array}$ & $\begin{array}{l}0.01 \\
0.04\end{array}$ & $\begin{array}{l}0.02 \\
0.04\end{array}$ & $\begin{array}{l}0.02 \\
0.04\end{array}$ & $\begin{array}{l}0.01 \\
0.04\end{array}$ & $\begin{array}{l}0.02 \\
0.04\end{array}$ & $\begin{array}{l}0.02 \\
0.04\end{array}$ & $\begin{array}{l}0.01 \\
0.04\end{array}$ & $\begin{array}{l}0.01 \\
0.05\end{array}$ & $\begin{array}{l}0.01 \\
0.05\end{array}$ & $\begin{array}{l}0.01 \\
0.04\end{array}$ & $\begin{array}{l}0.01 \\
0.05\end{array}$ & $\begin{array}{l}0.01 \\
0.04\end{array}$ & $\begin{array}{l}0.01 \\
0.04\end{array}$ & $\begin{array}{l}0.01 \\
0.04\end{array}$ & $\begin{array}{l}0.01 \\
0.04\end{array}$ & $\begin{array}{l}0.02 \\
0.04\end{array}$ & $\begin{array}{l}0.01 \\
0.04\end{array}$ & $\begin{array}{l}0.01 \\
0.04\end{array}$ & $\begin{array}{l}0.02 \\
0.04\end{array}$ & $\begin{array}{l}0.01 \\
0.04\end{array}$ & $\begin{array}{l}0.02 \\
0.04\end{array}$ & 0.04 & $\begin{array}{l}0.01 \\
0.04\end{array}$ & $\begin{array}{l}0.02 \\
0.04\end{array}$ & 0.04 & 0.04 & $\begin{array}{l}0.02 \\
0.04\end{array}$ & $\begin{array}{l}0.02 \\
0.04\end{array}$ & $\begin{array}{l}0.01 \\
0.04\end{array}$ & $\begin{array}{l}0.02 \\
0.04\end{array}$ & $\begin{array}{l}0.02 \\
0.04\end{array}$ & $\begin{array}{l}0.02 \\
0.04\end{array}$ \\
\hline
\end{tabular}




\begin{tabular}{|c|c|c|c|c|c|c|c|c|c|c|c|c|c|c|c|c|c|c|c|c|c|c|c|c|c|c|c|c|c|c|c|c|c|c|}
\hline $\begin{array}{l}\text { rofil garn } \\
\text { Pt } \\
\text { Dist }\end{array}$ & $\begin{array}{l}{ }_{6}^{6} \\
1 \\
0\end{array}$ & $\begin{array}{c}2 \\
20\end{array}$ & $\begin{array}{r}3 \\
41 \\
4\end{array}$ & $\begin{array}{l}4 \\
61 \\
\end{array}$ & $\begin{array}{c}5 \\
81\end{array}$ & $\begin{array}{c}6 \\
101\end{array}$ & $\begin{array}{c}7 \\
122\end{array}$ & $\begin{array}{c}8 \\
142\end{array}$ & $\begin{array}{c}9 \\
162\end{array}$ & $\begin{array}{c}10 \\
183\end{array}$ & $\begin{array}{l}11 \\
203\end{array}$ & $\begin{array}{l}12 \\
223\end{array}$ & $\begin{array}{l}13 \\
243\end{array}$ & $\begin{array}{c}16 \\
304\end{array}$ & $\begin{array}{l}17 \\
325\end{array}$ & $\begin{array}{c}18 \\
345\end{array}$ & $\begin{array}{l}19 \\
365\end{array}$ & $\begin{array}{l}21 \\
406\end{array}$ & $\begin{array}{l}22 \\
426\end{array}$ & $\begin{array}{l}23 \\
447\end{array}$ & $\begin{array}{l}24 \\
467\end{array}$ & $\begin{array}{l}26 \\
507\end{array}$ & $\begin{array}{l}27 \\
528\end{array}$ & $\begin{array}{l}28 \\
548\end{array}$ & $\begin{array}{l}29 \\
568\end{array}$ & $\begin{array}{l}30 \\
589\end{array}$ & $\begin{array}{l}31 \\
609\end{array}$ & $\begin{array}{l}32 \\
629\end{array}$ & $\begin{array}{l}33 \\
649\end{array}$ & $\begin{array}{l}34 \\
670\end{array}$ & $\begin{array}{l}35 \\
690\end{array}$ & $\begin{array}{c}36 \\
1094\end{array}$ & $\begin{array}{c}37 \\
1114\end{array}$ & $\begin{array}{c}38 \\
1133\end{array}$ \\
\hline sior & 39.80 & 39.51 & 38.41 & 38.64 & 38.58 & 38.58 & 38.94 & 39.17 & 39.71 & 39.45 & 39.43 & 38.80 & 37.05 & 39.05 & 39.51 & 39.63 & 39.07 & 38.79 & 42.21 & 39.71 & 39.8 & 39.27 & 39.88 & & 39.17 & & & 67 & & & 85 & & & \\
\hline $\mathrm{Al}_{22}$ & 22.34 & 22. & & & & & & & & & & & & & & & & & & & & & & & & & & & & & & & & \\
\hline $\mathrm{FeO}$ & 26.69 & 26.46 & 26.24 & & & 26. & & & & & & & & & & & & & & & & & & & & & & & & & & & 8.74 & 26.61 \\
\hline Mgo & 11,25 & 11,17 & 10,96 & 11 & 11,20 & 10,90 & & 10 & 10 & & & 10 & 10,66 & & & & & & & & & & & & & & & & & & & ,21 & 1,24 & $\begin{array}{lll}11,01 \\
0,5\end{array}$ \\
\hline $\begin{array}{l}\text { Mno } \\
\text { CaO }\end{array}$ & $\begin{array}{l}0.44 \\
110\end{array}$ & $\begin{array}{l}0.53 \\
1.22\end{array}$ & $\begin{array}{l}0.40 \\
1.32\end{array}$ & 0. & $\begin{array}{l}0.46 \\
1.42\end{array}$ & $\begin{array}{l}0.49 \\
1.56\end{array}$ & $\begin{array}{l}0.57 \\
1.64\end{array}$ & $\begin{array}{l}0.54 \\
1.72\end{array}$ & $\begin{array}{l}0.51 \\
1.38\end{array}$ & $\begin{array}{l}0.52 \\
1.98\end{array}$ & $\begin{array}{l}0.45 \\
2.02\end{array}$ & $\begin{array}{l}0.52 \\
2.00\end{array}$ & $\begin{array}{l}0.48 \\
1.95\end{array}$ & & $\begin{array}{l}0.56 \\
2.28\end{array}$ & $\begin{array}{l}0.4 \\
2.2\end{array}$ & & & & & & & & & & & & & & & & & & 0.52 \\
\hline $\begin{array}{l}\text { Cao } \\
\text { Total }\end{array}$ & $\begin{array}{c}1,10 \\
101.62\end{array}$ & $\begin{array}{c}1,22 \\
101.11\end{array}$ & $\begin{array}{c}1,32 \\
99.49\end{array}$ & $\begin{array}{c}1,37 \\
100.61\end{array}$ & $\begin{array}{l}1,42 \\
99.58\end{array}$ & $\begin{array}{c}1,56 \\
100.47\end{array}$ & $\begin{array}{c}1,64 \\
100.57\end{array}$ & $\begin{array}{c}1,72 \\
100.76\end{array}$ & $\begin{array}{c}1,83 \\
101.21\end{array}$ & $\begin{array}{c}1,98 \\
101.01\end{array}$ & $\begin{array}{c}2,02 \\
100.76\end{array}$ & $\begin{array}{c}2,00 \\
100.11\end{array}$ & $\begin{array}{c}1,95 \\
96.95\end{array}$ & $\begin{array}{c}2,16 \\
100.38\end{array}$ & $\begin{array}{c}2,28 \\
100.71\end{array}$ & $\begin{array}{c}2,25 \\
100.48\end{array}$ & $\begin{array}{c}2,22 \\
100.15\end{array}$ & $\begin{array}{c}2,25 \\
100.03\end{array}$ & $\begin{array}{c}2,06 \\
102.28\end{array}$ & $\begin{array}{c}2,09 \\
101.14\end{array}$ & $\begin{array}{c}2,14 \\
101.45\end{array}$ & & & $\begin{array}{c}1,77 \\
101.18\end{array}$ & $\begin{array}{c}1,62 \\
100.41\end{array}$ & $\begin{array}{c}1,44 \\
101.15\end{array}$ & $\begin{array}{c}1,31 \\
100.58\end{array}$ & $\begin{array}{c}1,23 \\
101.51\end{array}$ & $\begin{array}{c}1,01 \\
101.60\end{array}$ & $\begin{array}{c}1,05 \\
101.63\end{array}$ & $\begin{array}{c}1,14 \\
101.13\end{array}$ & $\begin{array}{c}1,02 \\
101.04\end{array}$ & $\begin{array}{c}1,02 . \\
101.07\end{array}$ & $\begin{array}{c}1,06 \\
100.72\end{array}$ \\
\hline $\mathrm{Si}$ & & & & & & & & & & & & & & & & & & & & & & & & & & & & & & & & & & \\
\hline $\mathrm{Al}$ & 1,978 & & & & & & & & & & & & & & & & & & & & & & & & & & & & & & & & & \\
\hline $\mathrm{Fe}$ & & & & & & & & & & & & & & & & & & & & & & & & & & & & & & & & & & \\
\hline $\mathrm{Mg}$ & & & & & & & & & & & & & & & & & & & & & & & & & & & & & & & & & & ,245, \\
\hline $\begin{array}{l}\text { Mn } \\
\text { Ca }\end{array}$ & $\begin{array}{l}0.028 \\
0.088\end{array}$ & 0.034 & 0.026 & 0.4 & 0 & & 0.037 & & & & $0 . c$ & & & & & & 0 & & & & & & & & & & & & & & & & 033 & 0.033 \\
\hline & & & & & & & & & & & & & & 0.1110 & 0.100 & & & & & & & 0.10 & 0.144 & & & & & & 0.001 & & 0.092 & 0.083 & 0.083 & 0.086 \\
\hline MgRat & 0.4 & 0. & & & & & & & & & & & & & & & & & & & & & & & & & & & & & & & & \\
\hline Alm & 0.55 & 0.55 & & 0.55 & 0.4 & & 0.5 & 0.5 & & & & & & & & & & & & & & & & & & & & & & & & & & \\
\hline $\begin{array}{l}\text { Pyr } \\
\text { Sypr }\end{array}$ & $\begin{array}{l}0.41 \\
0.01\end{array}$ & $\begin{array}{l}0.4 \\
0.4\end{array}$ & & $\begin{array}{l}0.40 \\
0.0\end{array}$ & 0. & & $\begin{array}{l}0.4 \\
0.0\end{array}$ & & & & & & & & & 0 & & & & & & 0. & & & & & & & & & & & & \\
\hline & . & & & 0.04 & 0.04 & & $\begin{array}{l}0.01 \\
0.04\end{array}$ & 0 & & s & $\begin{array}{l}0.01 \\
0.05\end{array}$ & & & $\begin{array}{l}0.01 \\
0.01\end{array}$ & 0.06 & & $\begin{array}{l}0.01 \\
0.06\end{array}$ & 0.06 & 0.06 & 0.06 & 0.06 & 0.05 & 0.05 & 0.05 & 0.04 & 0.04 & 0.04 & 0.03 & 0.03 & 0.03 & 0.03 & $\begin{array}{l}0.01 \\
0.03\end{array}$ & $\begin{array}{l}0.01 \\
0.03\end{array}$ & $\begin{array}{l}0.01 \\
0.03\end{array}$ \\
\hline
\end{tabular}




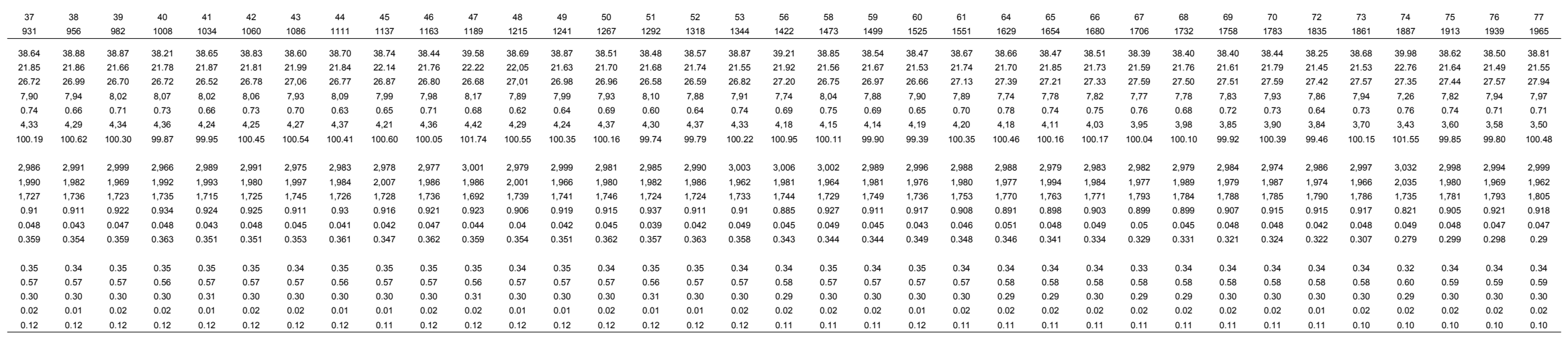

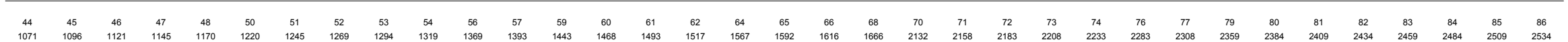

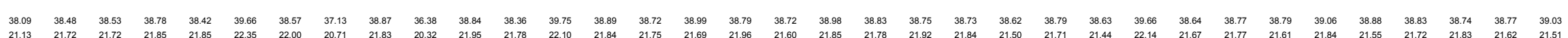

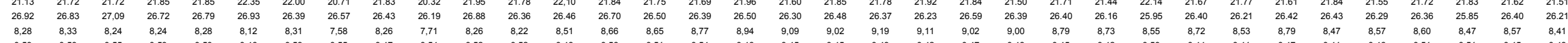

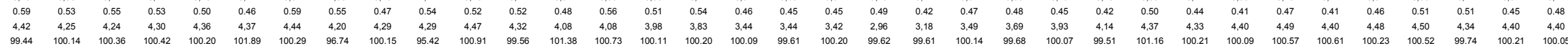

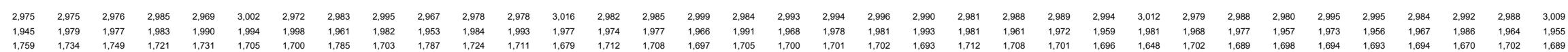

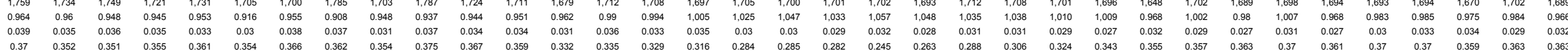
$\begin{array}{lllllllllllllllllllllllllllllllllllllllll}0.35 & 0.36 & 0.35 & 0.36 & 0.36 & 0.35 & 0.36 & 0.34 & 0.36 & 0.34 & 0.35 & 0.36 & 0.36 & 0.37 & 0.37 & 0.37 & 0.38 & 0.38 & 0.38 & 0.38 & 0.38 & 0.38 & 0.38 & 0.37 & 0.37 & 0.37 & 0.37 & 0.37 & 0.37 & 0.36 & 0.37 & 0.37 & 0.37 & 0.37 & 0.36 \\ 0.56 & 0.56 & 0.57 & 0.56 & 0.56 & 0.57 & 0.56 & 0.58 & 0.56 & 0.57 & 0.56 & 0.56 & 0.56 & 0.56 & 0.56 & 0.56 & 0.56 & 0.56 & 0.56 & 0.56 & 0.56 & 0.56 & 0.55 & 0.56 & 0.55 & 0.55 & 0.55 & 0.55 & 0.55 & 0.56 & 0.55 & 0.55 & 0.55 & 0.55 & 0.55\end{array}$

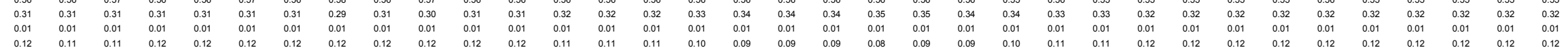

\begin{tabular}{|c|c|c|c|c|c|c|c|c|c|c|c|c|c|c|c|c|c|c|c|c|c|c|c|c|c|c|}
\hline $\begin{array}{c}44 \\
1307\end{array}$ & $\begin{array}{c}45 \\
1328\end{array}$ & $\begin{array}{c}46 \\
1349\end{array}$ & $\begin{array}{c}47 \\
1369\end{array}$ & $\begin{array}{c}48 \\
1399\end{array}$ & $\begin{array}{c}49 \\
1410\end{array}$ & $\begin{array}{c}50 \\
1431\end{array}$ & $\begin{array}{c}51 \\
1451\end{array}$ & $\begin{array}{c}52 \\
1472\end{array}$ & $\begin{array}{c}53 \\
1493\end{array}$ & $\begin{array}{c}54 \\
1513\end{array}$ & $\begin{array}{c}56 \\
1554\end{array}$ & $\begin{array}{c}57 \\
1575\end{array}$ & $\begin{array}{c}58 \\
1595\end{array}$ & $\begin{array}{c}59 \\
1616\end{array}$ & $\begin{array}{c}60 \\
1637\end{array}$ & $\begin{array}{c}61 \\
1657\end{array}$ & $\begin{array}{c}62 \\
1678\end{array}$ & $\begin{array}{c}64 \\
1719\end{array}$ & $\begin{array}{c}65 \\
1739\end{array}$ & $\begin{array}{c}66 \\
1760\end{array}$ & $\begin{array}{c}67 \\
1781\end{array}$ & $\begin{array}{c}68 \\
1801\end{array}$ & $\begin{array}{c}69 \\
1822\end{array}$ & $\begin{array}{c}70 \\
1842\end{array}$ & $\begin{array}{c}71 \\
1863\end{array}$ & $\begin{array}{c}72 \\
1883\end{array}$ \\
\hline .68 & 38.15 & 38.59 & 38.53 & 38.55 & 38.10 & 38.28 & 38.41 & 37.59 & 38.39 & 38.21 & 38.4 & 38.45 & 36.73 & 8.43 & 8.57 & 38.72 & 38.06 & 8.32 & 38.29 & & 8.72 & 38.83 & 3.58 & 56 & 38.53 & 92 \\
\hline & & & 21.64 & 21.84 & & & & & & & & & 20.87 & & & & & & 21.57 & & & & & & 21.77 & 21.64 \\
\hline 27.22 & 27.32 & 27.38 & 26.84 & 27.57 & 27.35 & 27. & 27.56 & .08 & & 27.00 & 27,12 & & 27.25 & 27.24 & 27.42 & 27.44 & 27.67 & 27.65 & 27.76 & 27.69 & 28.19 & 28,05 & 27.99 & 27.97 & 28,08 & 28.32 \\
\hline 8,82 & 8,85 & 8,86 & 8,74 & 8,79 & 8,73 & 8,93 & 8,65 & 9,05 & 8,76 & 8,88 & 8,72 & 8,83 & 7,68 & 8,75 & 81 & 8,46 & 9,01 & 9,05 & 9,12 & 9,08 & 9,21 & 9,24 & 31 & 9,22 & 9,39 & \\
\hline 0.62 & 0.66 & 0.60 & 0.62 & 0.64 & 0.62 & 0.66 & 0.60 & 0.56 & 0.71 & 0.62 & 0.64 & 0.58 & 0.66 & 0.60 & 0.71 & 0.56 & 0.68 & 0.53 & 0.59 & 0.69 & 0.64 & 0.66 & 69 & 0.61 & 0.61 & 67 \\
\hline $\begin{array}{r}2,98 \\
\end{array}$ & $\begin{array}{l}2,94 \\
097\end{array}$ & $\begin{array}{l}3,08 \\
308\end{array}$ & 3,10 & 3,14 & 3,28 & 3,30 & 3,21 & 3,19 & 3,26 & 3,20 & 3,19 & 3,10 & 3,00 & 3,01 & 2,86 & 2,73 & 2,81 & 2,41 & 2,38 & 2,27 & 2,15 & 2,08 & & 1,84 & 1,67 & 1,48 \\
\hline 100.13 & 99.73 & 99.97 & 99.48 & 100.52 & 99.80 & 100.44 & 100.21 & 98.81 & 100.29 & 99.38 & 99.43 & 100.03 & 96.19 & 99.63 & 99.78 & 99.51 & 99.61 & 99.59 & 99.70 & 101.15 & 100.64 & 100.63 & 100.26 & 100.01 & 100.05 & 99.48 \\
\hline 2,984 & 2,961 & 2,987 & 2,990 & 2,970 & 2,959 & 2,952 & 2,969 & 2,949 & 2,970 & 2,974 & 2,992 & 2,977 & 2,977 & 2,983 & 2,999 & 3,000 & 2,965 & 2,976 & 2,973 & 3,000 & 2,978 & 2,988 & 2,976 & 2,980 & 2,976 & 2,955 \\
\hline 1,983 & 1,996 & 1,958 & 1,979 & 1,983 & 1,9 & 1,993 & 1,985 & 1,974 & 1,963 & 1,970 & 1,955 & 1,966 & 1,990 & 1,976 & 1.,958 & 1,9 & 1,963 & 1,979 & 1,973 & 1,982 & & & & 1,986 & 1,982 & 1,987 \\
\hline 1,756 & 1,773 & 1,772 & 1,742 & 1,776 & 1,777 & 1,763 & 1,782 & 1,777 & 1,788 & 1,758 & 1,765 & 1,783 & 1,843 & 1,768 & 1,778 & 1,781 & 1,802 & 1,796 & 1,802 & 1,765 & 1,813 & 1,803 & & 1,807 & 1,814 & 1,845 \\
\hline 1,014 & 1,024 & 1,023 & 1,011 & 1,009 & 1,011 & 1,026 & 0.997 & 1,058 & 1,010 & 1,031 & 1,011 & 1,019 & 0.926 & 1,012 & 1,018 & 0.979 & 1,045 & 1,048 & 1,055 & 1,032 & 1,056 & 1,059 & 71 & 1,063 & 1,081 & 1,097 \\
\hline 0.04 & 0.044 & 0.039 & 0.041 & 0.041 & 0.041 & 0.043 & 0.039 & & 0.047 & 0.041 & & 0.038 & 0.045 & 0.039 & 0.047 & 0.037 & 0.045 & 0.035 & & & 0.042 & & & 0.04 & 0.04 & 0.044 \\
\hline 0.246 & 0.244 & 0.256 & 0.258 & 0.259 & 0.273 & 0.273 & 0.266 & 0.268 & 0.27 & 0.267 & 0.266 & 0.257 & 0.26 & 0.25 & 0.237 & 0.227 & 0.234 & 0.2 & 0.198 & 0.185 & 0.177 & 0.171 & 0.16 & 0.152 & 0.139 & 0.124 \\
\hline 0.3 & 0.37 & 0.3 & & 0.3 & & 0. & 0.3 & & & & & & & 0. & & & & 0.37 & & & & & & 0.37 & 37 & 37 \\
\hline 0.58 & 0.58 & 0.57 & 0.57 & 0.58 & 0.57 & 0.5 & & & & & & & & & & & & & & & & & & 9 & & 59 \\
\hline 0.33 & 0.33 & 0.33 & 0.33 & 0.33 & 0.33 & 0.33 & 0.32 & 0.34 & 0.32 & 0.33 & 0.33 & 0.33 & 0.30 & 0.33 & 0.33 & 0.32 & 0.33 & 0.34 & & 0.34 & 0.34 & 34 & 0.35 & 0.35 & 0.35 & 0.35 \\
\hline $\begin{array}{l}0.01 \\
0.08\end{array}$ & $\begin{array}{l}0.01 \\
0.08\end{array}$ & $\begin{array}{l}0.01 \\
0.08\end{array}$ & $\begin{array}{l}0.01 \\
0.09\end{array}$ & $\begin{array}{l}0.01 \\
0.08\end{array}$ & 0.01 & $\begin{array}{l}0.01 \\
0.09\end{array}$ & $\begin{array}{l}0.01 \\
0.09\end{array}$ & $\begin{array}{l}0.01 \\
0.09\end{array}$ & $\begin{array}{l}0.02 \\
0.09\end{array}$ & 009 & 0.01 & $\begin{array}{l}0.01 \\
0.08\end{array}$ & 0.09 & $\begin{array}{l}0.01 \\
0.08\end{array}$ & 0.02 & $\begin{array}{l}0.01 \\
0.08\end{array}$ & 0.08 & 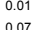 & $\begin{array}{l}0.01 \\
0.06\end{array}$ & 0.06 & $\begin{array}{l}0.01 \\
0.01\end{array}$ & $\begin{array}{l}0.01 \\
0.06\end{array}$ & $\begin{array}{l}0.02 \\
0.05\end{array}$ & $\begin{array}{l}0.01 \\
0.05\end{array}$ & $\begin{array}{l}0.01 \\
0.05\end{array}$ & $\begin{array}{l}0.01 \\
0.04\end{array}$ \\
\hline & & & & & & & & & & & & & & & & & & & & & & & & & & \\
\hline
\end{tabular}




\begin{tabular}{|c|c|c|c|c|c|c|c|c|c|c|c|c|c|c|c|c|c|c|c|c|c|c|c|c|c|c|c|c|c|c|c|c|c|c|}
\hline $\begin{array}{l}35 \\
680\end{array}$ & $\begin{array}{l}36 \\
700\end{array}$ & $\begin{array}{l}37 \\
720 \\
\end{array}$ & $\begin{array}{l}38 \\
740\end{array}$ & $\begin{array}{l}39 \\
760\end{array}$ & $\begin{array}{l}40 \\
780\end{array}$ & $\begin{array}{c}41 \\
1104 \\
\end{array}$ & $\begin{array}{c}42 \\
1123 \\
\end{array}$ & $\begin{array}{c}43 \\
1143 \\
\end{array}$ & $\begin{array}{c}44 \\
1162 \\
\end{array}$ & $\begin{array}{c}45 \\
1182 \\
\end{array}$ & $\begin{array}{c}46 \\
1201 \\
\end{array}$ & $\begin{array}{c}47 \\
1221 \\
\end{array}$ & $\begin{array}{c}48 \\
1240\end{array}$ & $\begin{array}{c}49 \\
1260\end{array}$ & $\begin{array}{c}51 \\
1637 \\
\end{array}$ & $\begin{array}{c}52 \\
1657\end{array}$ & $\begin{array}{c}53 \\
1678\end{array}$ & $\begin{array}{c}54 \\
1699\end{array}$ & $\begin{array}{c}55 \\
1719\end{array}$ & $\begin{array}{c}56 \\
1739 \\
\end{array}$ & $\begin{array}{c}57 \\
1760\end{array}$ & $\begin{array}{c}58 \\
1788\end{array}$ & $\begin{array}{c}59 \\
1801\end{array}$ & $\begin{array}{c}60 \\
1821\end{array}$ & $\begin{array}{c}61 \\
1842\end{array}$ & $\begin{array}{c}62 \\
1862 \\
\end{array}$ & $\begin{array}{c}63 \\
1883 \\
\end{array}$ & $\begin{array}{c}64 \\
1903\end{array}$ & $\begin{array}{c}65 \\
1924 \\
\end{array}$ & $\begin{array}{c}66 \\
1944 \\
\end{array}$ & $\begin{array}{c}67 \\
1965\end{array}$ & $\begin{array}{c}68 \\
1985\end{array}$ & $\begin{array}{c}69 \\
2006\end{array}$ & $\begin{array}{c}70 \\
2026\end{array}$ \\
\hline 38.84 & 39.00 & 39.07 & 38.63 & 39.13 & 39.36 & 39.07 & 39.32 & 39.69 & 38.83 & 39.24 & 39.30 & 38.70 & 39.37 & 39.69 & 39.61 & 39.37 & 126 & 38.80 & 88 & 48 & 38.75 & 39.12 & 53 & 38.57 & & & 39.19 & & 8.55 & & & & & \\
\hline 21.98 & 21.99 & 21.89 & 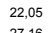 & 21.98 & 21.97 & 22,12 & 22,12 & 21.97 & 22.25 & 22,07 & & 22.15 & 21.95 & 22,08 & 22.19 & 21.92 & 22.27 & 21.86 & 21.94 & 21.92 & 21.97 & 21.94 & 21.94 & 22.15 & 21.85 & 21.97 & 22,03 & 22,11 & 22.17 & 21.94 & 22,08 & & & 21.96 \\
\hline $\begin{array}{l}27,01 \\
9.95\end{array}$ & $\begin{array}{l}27,02 \\
207\end{array}$ & $\begin{array}{r}26.65 \\
\end{array}$ & $\begin{array}{l}27.16 \\
\end{array}$ & 26.99 & 27,11 & 26.31 & $\begin{array}{r}26.65 \\
1055\end{array}$ & 27,02 & $\begin{array}{l}26.49 \\
105\end{array}$ & $\begin{array}{r}26.87 \\
1057\end{array}$ & $\begin{aligned} 26.61 \\
\end{aligned}$ & 26.56 & 26.79 & $\begin{array}{l}27,01 \\
105\end{array}$ & 26.19 & $\begin{array}{r}26.37 \\
1057\end{array}$ & $\begin{array}{l}26.54 \\
1.056\end{array}$ & 26.39 & $\begin{array}{r}26.69 \\
1039\end{array}$ & 26.36 & 25.78 & 26.68 & 26.21 & 26.22 & 26.23 & 26.19 & 26,04 & 96 & 26.33 & 26.38 & 26.29 & 26.19 & 26,10 & $\begin{array}{r}26.47 \\
1.057\end{array}$ \\
\hline $\begin{array}{l}9,90 \\
0.58\end{array}$ & $\begin{array}{l}9,97 \\
0.54\end{array}$ & $\begin{array}{l}\begin{array}{l}0,01,01 \\
0.60\end{array}\end{array}$ & $\begin{array}{l}10,29 \\
0.53\end{array}$ & $\begin{array}{r}10,39 \\
0.57\end{array}$ & $\begin{array}{l}1,0,50 \\
0.63\end{array}$ & $\begin{array}{l}10,41 \\
0.46\end{array}$ & $\begin{array}{l}10,55 \\
0,49\end{array}$ & $\begin{array}{l}1,065 \\
0.58\end{array}$ & $\begin{array}{l}10,51 \\
0.53\end{array}$ & $\begin{array}{l}1,0,59 \\
0.58\end{array}$ & $\begin{array}{l}1,0,59 \\
0,56\end{array}$ & $\begin{array}{l}10,47 \\
0.58\end{array}$ & $\begin{array}{l}1,0.46 \\
0.58\end{array}$ & $\begin{array}{l}\begin{array}{l}1,051 \\
0.51\end{array} \\
0.51\end{array}$ & $\begin{array}{l}1,0,72 \\
0,48\end{array}$ & $\begin{array}{l}1,056 \\
0.55\end{array}$ & $\begin{array}{l}1,0,56 \\
0.52\end{array}$ & $\begin{array}{l}\begin{array}{l}1,043 \\
0.57\end{array} \\
0.57\end{array}$ & $\begin{array}{l}10,338 \\
0.60\end{array}$ & $\begin{array}{l}10,28 \\
0.51\end{array}$ & ${ }_{33}^{28}$ & $\begin{array}{l}1,024 \\
0.52\end{array}$ & 0.018 & $\begin{array}{l}10,26 \\
0,55\end{array}$ & $\begin{array}{l}1,039 \\
0,59\end{array}$ & $\begin{array}{l}10,35 \\
0.50\end{array}$ & 23 & & $0, \frac{24}{50}$ & 32 & 28 & $\begin{array}{l}37 \\
46\end{array}$ & $\begin{array}{l}3,37 \\
57\end{array}$ & ,, 511 \\
\hline 2,01 & 1,93 & 1,84 & 1,59 & 1,53 & 1,34 & 1,29 & 1,29 & 1,32 & 1,46 & 1,38 & 1,38 & 1,33 & 1,38 & 1,24 & 1,37 & 1.44 & $\begin{array}{l}0.52 \\
1.73\end{array}$ & $\begin{array}{l}0.57 \\
1.88\end{array}$ & 2,11 & $\begin{array}{l}0.57 \\
2.29\end{array}$ & $\begin{array}{l}0.63 \\
2.18\end{array}$ & 2,28 & $\begin{array}{l}2.37 \\
2.34\end{array}$ & $\begin{array}{l}0.55 \\
2.30\end{array}$ & 2,36 & & $\begin{array}{l}0.53 \\
229\end{array}$ & 221 & $\begin{array}{l}0.50 \\
2.18\end{array}$ & & & & $\begin{array}{l}0.57 \\
1.94\end{array}$ & $\begin{array}{l}0.56 \\
1.79\end{array}$ \\
\hline 100.38 & 100.45 & 100.07 & 100.25 & 100.59 & 100.91 & 99.66 & 100.43 & 101.22 & 100.07 & 100.73 & 100.67 & 99.79 & 100.53 & 101.04 & 100.56 & 100.21 & $\begin{array}{l}9,15 \\
99.88\end{array}$ & $\begin{array}{l}9,06 \\
99.93\end{array}$ & 100.61 & $\begin{array}{c}1,2560.86 \\
100\end{array}$ & $\begin{array}{l}2,169 \\
999.59\end{array}$ & $\begin{array}{l}2,28 \\
100.77\end{array}$ & $\begin{array}{l}9,54 \\
99.72\end{array}$ & $\begin{array}{l}2,30 \\
100.05\end{array}$ & $\begin{array}{l}2,00 \\
99.99\end{array}$ & $\begin{array}{l}2,32 \\
100.55\end{array}$ & $\begin{array}{l}2,59 \\
100.31\end{array}$ & $\begin{array}{l}2,7.74 \\
99.74\end{array}$ & $\begin{array}{l}2,167.97 \\
9997\end{array}$ & $\begin{array}{l}100.57 \\
100\end{array}$ & $\begin{array}{l}2,11 \\
100.25\end{array}$ & $\begin{array}{l}2,02 \\
99.64\end{array}$ & $\begin{array}{r}1,54.27 \\
100.27\end{array}$ & 100.73 \\
\hline 2,976 & 2,984 & 2,995 & 2,963 & 2,985 & 2,992 & 2,995 & 2,995 & 3,003 & 2,971 & 2,985 & 2,987 & 2,972 & 3,000 & 3,006 & 3,004 & 3,003 & 2,941 & 2,978 & 2,969 & 2,999 & 2,979 & & 2,966 & 2,958 & & & & & 2,959 & & & 2,959 & 3.006 & \\
\hline 1,985 & 1,983 & 1,978 & 1,993 & 1,976 & 1,969 & 1,998 & 1,986 & 1,959 & 2,007 & 1,979 & 1,991 & & & 1,971 & 1,984 & & & & & & & & & & & & & & 2,006 & & & & & 967 \\
\hline 1,731 & 1,728 & 1,708 & 1,742 & 1,722 & 1,723 & 1,687 & 1,697 & 1,710 & 1,695 & 1,710 & 1,692 & 1,706 & 1,707 & 1,711 & 1.,661 & 1,683 & 1,706 & 1,694 & 1,705 & 1,675 & 557 & 1,7 & 1,687 & 82 & & 1,669 & 1,662 & & 1,690 & & & 1,6855 & ;64 & 882 \\
\hline 1,137 & 1,137 & 1,1 & 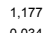 & 1,182 & 1,190 & 1,1 & $\begin{array}{l}1,198 \\
, 038\end{array}$ & 1,2 & $\begin{array}{l}1,199 \\
, 099\end{array}$ & & 1, & 1,1 & & 1, & 12 & & & & & & & & 1,168 & & & & & & 172 & & & 189 & & 190 \\
\hline $\begin{array}{l}0.038 \\
0.1658\end{array}$ & $\begin{array}{l}0.035 \\
0.158\end{array}$ & $\begin{array}{l}0.039 \\
0.151\end{array}$ & $\begin{array}{l}0.034 \\
0.131\end{array}$ & $\begin{array}{l}0.037 \\
0.025\end{array}$ & $\begin{array}{l}0.04 \\
0.190\end{array}$ & $\begin{array}{l}0.03 \\
0.106\end{array}$ & $\begin{array}{l}0.031 \\
0.105\end{array}$ & $\begin{array}{l}0.037 \\
0.107\end{array}$ & $\begin{array}{l}0.034 \\
0.119\end{array}$ & $\begin{array}{l}0.038 \\
0.111\end{array}$ & $\begin{array}{l}0.036 \\
0.113\end{array}$ & $\begin{array}{l}0.038 \\
0.109\end{array}$ & $\begin{array}{l}0.037 \\
0.113\end{array}$ & $\begin{array}{c}0.033 \\
0.1\end{array}$ & $\begin{array}{l}0.031 \\
0.111\end{array}$ & $\begin{array}{l}0.035 \\
0118\end{array}$ & $\begin{array}{l}0.034 \\
0.1434\end{array}$ & $\begin{array}{l}0.037 \\
0.153\end{array}$ & $\begin{array}{l}0.039 \\
0.179\end{array}$ & $\begin{array}{l}0.033 \\
0.187\end{array}$ & $\begin{array}{l}0.041 \\
0.1979\end{array}$ & $\begin{array}{l}0.034 \\
0.186\end{array}$ & $\begin{array}{l}0.033 \\
0.1933\end{array}$ & $\begin{array}{l}0.035 \\
0.1998\end{array}$ & $\begin{array}{l}0.038 \\
0.1948\end{array}$ & $\begin{array}{l}0.033 \\
0.0193\end{array}$ & $\begin{array}{l}0.034 \\
0.1848\end{array}$ & 0.033 & 0.032 & $\begin{array}{l}0.036 \\
0.171\end{array}$ & 0.035 & $\begin{array}{l}0.03 \\
0.167\end{array}$ & $\begin{array}{l}0.037 \\
0.158\end{array}$ & $\begin{array}{l}0.036 \\
0.146\end{array}$ \\
\hline 0. & 0. & 0. & & & & & & & & & & & & & & & & & & & & & & & & & & & & & & & & \\
\hline 0.5 & & 0.5 & 0.5 & & 0. & & & 0. & & 0. & 0. & & & & & & & & & & & & & & & & & & & & & & 5 & \\
\hline 0.37 & 0.37 & 0.38 & 0.38 & 0.39 & 0.39 & 0.40 & 0.40 & 0.39 & 0.39 & 0.39 & 0.40 & 0.39 & 0.39 & 0.39 & 0. & 0.4 & 0.39 & 0.39 & 0.38 & 0.38 & 0.39 & 0.38 & 0.38 & 0.38 & 0. & 0.38 & 0.38 & & 0.38 & 0.38 & & 39 & .39 & .39 \\
\hline P & 0.01 & 0.01 & 0.01 & 0.01 & 0.01 & 0.01 & 0.01 & 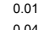 & 0.01 & 0.01 & 0.01 & 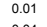 & 0.01 & 0.01 & 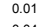 & . & 0.01 & 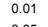 & 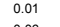 & 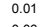 & 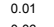 & 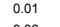 & 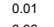 & & & 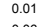 & & & 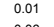 & 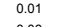 & & 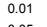 & 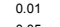 & 0.01 \\
\hline 0.05 & 0.05 & 0.05 & 0.04 & 0.04 & 0.04 & 0.04 & 0.04 & 0.04 & 0.04 & 0.04 & 0.04 & 0.04 & & 0.03 & 0.04 & & 0.05 & 0.05 & 0.06 & 0.06 & 0.06 & 0.06 & & 0.06 & 0.06 & 0.06 & 0.06 & 0.06 & 0.06 & & 0.06 & 0.05 & 0.05 & 0.05 \\
\hline
\end{tabular}

\begin{tabular}{|c|c|c|c|c|c|c|c|c|c|c|c|c|c|c|c|c|c|c|c|c|c|c|c|c|c|c|c|c|c|c|c|c|c|c|}
\hline $\begin{array}{l}40 \\
992 \\
992\end{array}$ & $\begin{array}{c}41 \\
1017 \\
\end{array}$ & $\begin{array}{c}42 \\
1042\end{array}$ & $\begin{array}{c}43 \\
1068 \\
\end{array}$ & $\begin{array}{c}44 \\
1093 \\
\end{array}$ & $\begin{array}{c}45 \\
1118 \\
\end{array}$ & $\begin{array}{c}48 \\
1195 \\
\end{array}$ & $\begin{array}{r}49 \\
1220 \\
\end{array}$ & $\begin{array}{c}50 \\
1246 \\
\end{array}$ & $\begin{array}{c}51 \\
1409\end{array}$ & $\begin{array}{c}52 \\
1434 \\
\end{array}$ & $\begin{array}{c}53 \\
1459 \\
145\end{array}$ & $\begin{array}{c}54 \\
1485\end{array}$ & $\begin{array}{c}55 \\
1510 \\
\end{array}$ & $\begin{array}{c}56 \\
1535 \\
\end{array}$ & $\begin{array}{c}57 \\
1560 \\
\end{array}$ & $\begin{array}{c}58 \\
1585 \\
\end{array}$ & $\begin{array}{c}59 \\
1610 \\
\end{array}$ & $\begin{array}{c}60 \\
1635\end{array}$ & $\begin{array}{c}64 \\
1736 \\
\end{array}$ & $\begin{array}{c}65 \\
1766 \\
\end{array}$ & $\begin{array}{c}66 \\
1787 \\
\end{array}$ & $\begin{array}{c}67 \\
1812 \\
\end{array}$ & $\begin{array}{c}69 \\
1862\end{array}$ & $\begin{array}{c}71 \\
1912 \\
\end{array}$ & $\begin{array}{c}72 \\
1937\end{array}$ & $\begin{array}{c}73 \\
1963 \\
\end{array}$ & $\begin{array}{c}75 \\
2013\end{array}$ & $\begin{array}{c}76 \\
2038\end{array}$ & $\begin{array}{c}77 \\
2063\end{array}$ & $\begin{array}{c}78 \\
2089\end{array}$ & $\begin{array}{c}79 \\
2114 \\
\end{array}$ & $\begin{array}{c}80 \\
2139 \\
\end{array}$ & $\begin{array}{c}81 \\
2164\end{array}$ & $\begin{array}{c}82 \\
2189 \\
\end{array}$ \\
\hline & 38.99 & 39.00 & 39.00 & 38.10 & 39.17 & 39.38 & 39.30 & 39.04 & & 39.78 & 38.6 & 39.11 & 39.08 & 39.77 & & & 39.88 & & & & & & 40.07 & & & 39.83 & & & 39.78 & & & & & \\
\hline 22,06 & & & 22.18 & 21. & 21.96 & 22.16 & 22. & 22,05 & 22.81 & 22.25 & 22.34 & 22.31 & 22.50 & 22.27 & 22.23 & 22.28 & 22.29 & 22.19 & 22.41 & 21.99 & 22.38 & 22.41 & 22.00 & & 22.34 & 22.23 & & & 22,07 & 19 & 22.29 & 22.21 & .20 & 22,05 \\
\hline 26.00 & 26.37 & 26.28 & 25.71 & 25.88 & 25.68 & 25.58 & 25.52 & 26,04 & 25.81 & 25.69 & 26.30 & 25.56 & 25.50 & 25.83 & 25.89 & 25.68 & 25.38 & 25.86 & 25.77 & 25.81 & 25.13 & 25.42 & 24.93 & 25.53 & 25,08 & 25.00 & 24.61 & 24.66 & 24.73 & .65 & 24.93 & 24.84 & 4.41 & 24.89 \\
\hline 11,02 & 11,13 & 11,20 & 11,06 & 11,31 & 11,44 & 11,32 & 11,51 & 11,40 & 11,30 & 11,48 & 11,53 & 11,52 & 11,67 & 11,58 & 11,47 & 11,31 & 11,53 & 11,31 & 11,45 & 11,29 & 11,30 & 11,21 & 11,14 & 11,13 & 10,81 & $\begin{array}{l}10,72 \\
0,51\end{array}$ & $\begin{array}{l}10,29 \\
0,47\end{array}$ & $\begin{array}{l}10,25 \\
0.52\end{array}$ & $\begin{array}{l}10,10 \\
0,57\end{array}$ & .33 & $\begin{array}{l}10,37 \\
0,47\end{array}$ & $\begin{array}{l}10,37 \\
0,55\end{array}$ &, 35 & 10,43 \\
\hline 0.54 & 0.48 & 0.52 & 0.56 & 0.55 & 0.50 & 0.59 & 0.50 & 0.51 & 0.42 & 0.56 & 0.41 & 0.40 & 0.48 & 0.46 & 0.42 & 0.43 & 0.49 & 0.52 & 0.50 & 0.54 & 88 & 0.40 & 0.46 & 48 & 0.46 & 0.51 & 0.47 & 0.52 & 0.57 & 53 & 0.47 & 0.55 & 46 & 0.48 \\
\hline $\begin{array}{c}1,57 \\
100.43\end{array}$ & $\begin{array}{c}1,46 \\
100.75\end{array}$ & $\begin{array}{c}1,34 \\
100.45\end{array}$ & $\begin{array}{l}1,32 \\
99.93\end{array}$ & $\begin{array}{l}1,15 \\
9894\end{array}$ & $\begin{array}{l}1,24 \\
9.999\end{array}$ & $\begin{array}{c}1,20 \\
100.23\end{array}$ & $\begin{array}{c}1,08 \\
100.20\end{array}$ & $\begin{array}{c}1,15 \\
100.19\end{array}$ & $\begin{array}{c}1.26 \\
10149\end{array}$ & $\begin{array}{c}1,08 \\
100.83\end{array}$ & $\begin{array}{c}0.99 \\
0.9023\end{array}$ & $\begin{array}{l}1,08 \\
99989\end{array}$ & $\begin{array}{c}1,01 \\
100.25\end{array}$ & $\begin{array}{l}1,08 \\
101100\end{array}$ & $\begin{array}{c}1.06 \\
10024\end{array}$ & $\begin{array}{c}1,15 \\
100049\end{array}$ & $\begin{array}{l}1,19 \\
100.75\end{array}$ & $\begin{array}{c}1,15 \\
100.66\end{array}$ & $\begin{array}{c}1,30 \\
1014,42\end{array}$ & $\begin{array}{c}1,36 \\
100.76\end{array}$ & $\begin{array}{c}1,48 \\
10104\end{array}$ & $\begin{array}{c}1,62 \\
100.86\end{array}$ & $\begin{array}{c}1.87 \\
100.47\end{array}$ & $\begin{array}{c}1,92 \\
101133\end{array}$ & $\begin{array}{c}2,54 \\
10.94\end{array}$ & $\begin{array}{r}2 ., 99 \\
101.27\end{array}$ & $\begin{array}{c}3,40 \\
300.79\end{array}$ & $\begin{array}{l}3,60 \\
0101.23\end{array}$ & $\begin{array}{c}3,65 \\
100.90\end{array}$ & $\begin{array}{l}3.67 \\
100.55\end{array}$ & $\begin{array}{c}3.54 \\
0.101 .51\end{array}$ & $\begin{array}{c}3,56 \\
0101818\end{array}$ & $\begin{array}{l}3,50 \\
30.000\end{array}$ & $\begin{array}{c}3,45 \\
101.11\end{array}$ \\
\hline 2.983 & 2,960 & 2.969 & 2.979 & 2,946 & 2,985 & 2,991 & 2.983 & 2,99 & 2,987 & 3,000 & 2,947 & 2,976 & 2,965 & & & 2,999 & 05 & & 2,999 & 006 & & 2,998 & 026 & 3.012 & 2,996 & 2.997 & & 3,010 & 008 & & 2.998 & & & \\
\hline 1,978 & 1,998 & 1,984 & 1,997 & 2,001 & 1,973 & 1,984 & 1,995 & 1,98 & 2,013 & 1,978 & 2,007 & 2,001 & 2,012 & 1,976 & 1,992 & $\begin{array}{l}1,987 \\
\end{array}$ & $\begin{array}{l}3,000 \\
1,979\end{array}$ & 1,978 & $\begin{array}{l}2,999 \\
1,981\end{array}$ & $\begin{array}{l}3,000 \\
1,959\end{array}$ & 1,980 & $\begin{array}{l}2,990 \\
1,990\end{array}$ & $\begin{array}{l}3,060 \\
1,958\end{array}$ & $\begin{array}{l}3,012 \\
1,961\end{array}$ & $\begin{array}{l}2,9060 \\
1,985\end{array}$ & $\begin{array}{l}2,977 \\
1,971\end{array}$ & & $\begin{array}{l}3,971 \\
1,973\end{array}$ & $\begin{array}{l}0,000 \\
1,967\end{array}$ & & $\begin{array}{l}2,990 \\
1,974\end{array}$ & 975 & & 961 \\
\hline 1,654 & 1,674 & 1,673 & 1,643 & 1,6 & 1,637 & 1,625 & 1,620 & 1,65 & 1,616 & 1,6 & 1,6 & 1,626 & 1,618 & 1,627 & 1,646 & & 99 & 1,636 & & 632 & 1,578 & & & & & 1,573 & & & & & & & & 571 \\
\hline $\begin{array}{l}1,250 \\
, 2020\end{array}$ & 1,259 & 1,271 & 1,259 & 1,303 & 1,300 & 1,281 & 1,302 & 1,295 & 1,261 & 1,290 & 1,311 & 1,307 & 1,320 & 1,300 & 1,299 & 1,275 & 1,2955 & 1,2 & 1,280 & 1,272 & 1,265 & 1,259 & 1,254 & & & 1,202 & & 1,150 & & & & & & 1,172 \\
\hline $\begin{array}{l}0.035 \\
0.128\end{array}$ & $\begin{array}{l}0.031 \\
0.119\end{array}$ & $\begin{array}{l}0.034 \\
0.109\end{array}$ & $\begin{array}{l}0.036 \\
0.108\end{array}$ & $\begin{array}{l}0.036 \\
0.0995\end{array}$ & $\begin{array}{l}0.032 \\
0.101\end{array}$ & $\begin{array}{l}0.038 \\
0.0098\end{array}$ & $\begin{array}{l}0.032 \\
0.088\end{array}$ & $\begin{array}{l}0.033 \\
0.0934\end{array}$ & $\begin{array}{l}0.027 \\
0.1010\end{array}$ & $\begin{array}{l}0.036 \\
0.087\end{array}$ & $\begin{array}{l}0.026 \\
0.0081\end{array}$ & $\begin{array}{l}0.026 \\
0.0088\end{array}$ & $\begin{array}{l}0.031 \\
0.0382\end{array}$ & $\begin{array}{l}0.029 \\
0.0097\end{array}$ & $\begin{array}{l}0.027 \\
0.078\end{array}$ & $\begin{array}{l}0.028 \\
0.0094\end{array}$ & $\begin{array}{l}0.031 \\
0.0996\end{array}$ & $\begin{array}{l}0.033 \\
0.0933\end{array}$ & 0.032 & $\begin{array}{l}0.035 \\
0.11\end{array}$ & $\begin{array}{l}0.037 \\
0.119\end{array}$ & $\begin{array}{l}0.026 \\
0.13\end{array}$ & $\begin{array}{l}0.03 \\
0.15\end{array}$ & $\begin{array}{l}0.03 \\
0.155\end{array}$ & & $\begin{array}{l}0.033 \\
0.243\end{array}$ & & $\begin{array}{l}0.033 \\
0.29\end{array}$ & $\begin{array}{l}0.036 \\
0.206\end{array}$ & & $\begin{array}{l}0.03 \\
0.258\end{array}$ & 0.035 & $\begin{array}{l}0.029 \\
0.226\end{array}$ & $\begin{array}{l}0.031 \\
0.279\end{array}$ \\
\hline & & & & & & & & & & & & & & & & & & & & & & & & & & 0.241 & & & & & 0.285 & 0.288 & & 0.279 \\
\hline 0.43 & 0.43 & 0.4 & 0.43 & 0.4 & 0.4 & 0.4 & 0.4 & 0.4 & 0.4 & & 0.4 & 0.45 & 0.4 & 0.4 & 0.4 & 0.44 & & 0.4 & 0.44 & 0.44 & 0.4 & $\begin{array}{l}0.44 \\
\end{array}$ & & 0.44 & 0.43 & & 0.43 & 0.43 & 0.42 & 0.43 & $\begin{array}{l}0.43 \\
.052\end{array}$ & 0.43 & 0.43 & 0.43 \\
\hline 0.54 & 0.5 & 0.5 & 0.54 & 0.4 & 0.5 & 0.5 & 0. & & & & 0 & & & & & & & & & & & & & & & & & & & & & & & 52 \\
\hline $\begin{array}{l}0.41 \\
0.01\end{array}$ & $\begin{array}{l}0.41 \\
0.01\end{array}$ & $\begin{array}{l}0.41 \\
0.11\end{array}$ & 0.41 & $\begin{array}{l}0.42 \\
0.01\end{array}$ & $\begin{array}{l}0.4 \\
0.0\end{array}$ & 0.4 & 0. & $\begin{array}{l}0.4 \\
0.0\end{array}$ & 0.42 & 0. & 0. & 0.4 & & & $\begin{array}{l}0.4 \\
0.0\end{array}$ & $\begin{array}{l}0.42 \\
0.01\end{array}$ & & & & & & & & & & & & & & & & $\begin{array}{l}38 \\
01 \\
01\end{array}$ & $\begin{array}{l}399 \\
99\end{array}$ & 88 \\
\hline $\begin{array}{l}0.01 \\
0.04\end{array}$ & $\begin{array}{l}0.01 \\
0.04\end{array}$ & $\begin{array}{l}0.01 \\
0.04\end{array}$ & $\begin{array}{l}0.01 \\
0.04\end{array}$ & $\begin{array}{l}0.01 \\
0.03\end{array}$ & $\begin{array}{l}0.01 \\
0.03\end{array}$ & $\begin{array}{l}0.01 \\
0.03\end{array}$ & $\begin{array}{l}0.01 \\
0.03\end{array}$ & $\begin{array}{l}0.01 \\
0.03\end{array}$ & $\begin{array}{l}0.01 \\
0.03\end{array}$ & $\begin{array}{l}0.01 \\
0.03\end{array}$ & $\begin{array}{l}0.01 \\
0.03\end{array}$ & $\begin{array}{l}0.01 \\
0.03\end{array}$ & $\begin{array}{l}0.01 \\
0.03\end{array}$ & $\begin{array}{l}0.01 \\
0.03\end{array}$ & $\begin{array}{l}0.01 \\
0.03\end{array}$ & $\begin{array}{l}0.01 \\
0.03\end{array}$ & $\begin{array}{l}0.01 \\
0.03\end{array}$ & $\begin{array}{l}0.01 \\
0.03\end{array}$ & $\begin{array}{l}0.01 \\
0.03\end{array}$ & $\begin{array}{l}0.01 \\
0.04\end{array}$ & 0.04 & $\begin{array}{l}0.01 \\
0.04\end{array}$ & 0.05 & $\begin{array}{l}0.01 \\
0.05\end{array}$ & 0.07 & 0.08 & $\begin{array}{l}0.01 \\
0.09\end{array}$ & 0.110 & $\begin{array}{l}0.01 \\
0.10\end{array}$ & $\begin{array}{l}0.01 \\
0.10\end{array}$ & 0.09 & $\begin{array}{l}0.01 \\
0.09\end{array}$ & $\begin{array}{l}0.01 \\
0.09\end{array}$ & $\begin{array}{l}0.01 \\
0.09\end{array}$ \\
\hline
\end{tabular}

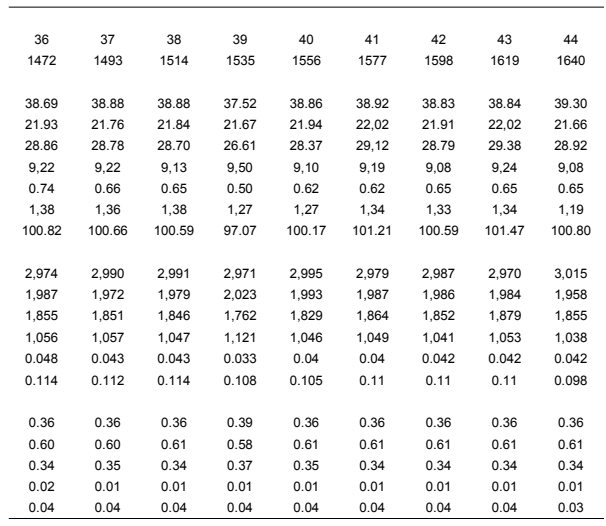




\begin{tabular}{|c|c|c|c|c|c|c|c|c|c|c|c|c|c|c|c|c|c|c|c|c|c|c|c|c|c|c|c|c|c|c|c|c|c|c|}
\hline $\begin{array}{c}39 \\
1153\end{array}$ & $\begin{array}{c}41 \\
1193\end{array}$ & $\begin{array}{c}42 \\
1213\end{array}$ & $\begin{array}{c}43 \\
1232\end{array}$ & $\begin{array}{c}44 \\
1252\end{array}$ & $\begin{array}{c}45 \\
1272\end{array}$ & $\begin{array}{c}46 \\
1292\end{array}$ & $\begin{array}{c}47 \\
1311\end{array}$ & $\begin{array}{c}48 \\
1331\end{array}$ & $\begin{array}{c}49 \\
1351\end{array}$ & $\begin{array}{c}50 \\
1371\end{array}$ & $\begin{array}{c}51 \\
1390\end{array}$ & $\begin{array}{c}52 \\
1410\end{array}$ & $\begin{array}{c}53 \\
1430\end{array}$ & $\begin{array}{c}54 \\
1450\end{array}$ & $\begin{array}{c}55 \\
1469\end{array}$ & $\begin{array}{c}56 \\
1489\end{array}$ & $\begin{array}{c}57 \\
1509\end{array}$ & $\begin{array}{c}58 \\
1529\end{array}$ & $\begin{array}{c}59 \\
1548\end{array}$ & $\begin{array}{c}60 \\
1568\end{array}$ & $\begin{array}{c}61 \\
1588\end{array}$ & $\begin{array}{c}63 \\
1627\end{array}$ & $\begin{array}{c}64 \\
1647\end{array}$ & $\begin{array}{c}65 \\
1667\end{array}$ & $\begin{array}{c}66 \\
1687\end{array}$ & $\begin{array}{c}67 \\
1706\end{array}$ & $\begin{array}{c}68 \\
1726\end{array}$ & $\begin{array}{c}69 \\
1746\end{array}$ & $\begin{array}{c}70 \\
1766\end{array}$ & $\begin{array}{c}71 \\
1785\end{array}$ & $\begin{array}{c}72 \\
1805\end{array}$ & $\begin{array}{c}73 \\
1825\end{array}$ & $\begin{array}{c}74 \\
1845\end{array}$ & $\begin{array}{c}75 \\
1865\end{array}$ \\
\hline 39.32 & 39.37 & 39.56 & 39.45 & 38.68 & 38.90 & 39.67 & 38.86 & 39.79 & 39.33 & 38.68 & 38.81 & 38.67 & 39.25 & 38.80 & 38.73 & 38.96 & 38.79 & 39.53 & 44 & 39.68 & 38.54 & & 38.86 & 38.66 & & 8.78 & 3.86 & & 39.52 & 39.04 & 109 & & 9.31 & \\
\hline 21.86 & 22,12 & 22,02 & 22,07 & 22.26 & 22.16 & 22.28 & 22.24 & 22.56 & & & & & & & & & & & & & & & & & & & 21. & & & & & & & 07 \\
\hline 26.50 & 26.59 & 26.72 & 26.67 & 26.52 & 26.67 & 26.61 & 26.89 & 26.72 & 26.60 & 26.72 & 26.46 & 26.43 & 26.58 & 26.40 & 26.67 & 26.24 & 26.48 & 26.61 & 26.56 & 26.20 & 26.6 & 26.36 & & 26.4 & & & 26. & & & 26.37 & & & 26.90 & \\
\hline 11,10 & 11,27 & 11,19 & 11,10 & 11,15 & 11,10 & 10,99 & 11,00 & 10,94 & 10,85 & 10,84 & 10,81 & 10,76 & 10,71 & 10,53 & 10,61 & 10,58 & 10,59 & 10,47 & 10,40 & 10,48 & 10.46 & 10,21 & 10,32 & 10,20 & 10,21 & 10.41 & 10,17 & 10,31 & 10.28 & 10.42 & & 10,22 & 10,26 & .28 \\
\hline 0.47 & 0.50 & 0.45 & 0.51 & 0.53 & 0.40 & 0.44 & 0.51 & 0.43 & 0.45 & 0.48 & 0.53 & 0.52 & 0.48 & 0.46 & 0.48 & 0.49 & 0.54 & 0.53 & 0.48 & 0.46 & 0.58 & 0.51 & 0.47 & 0.45 & 0.49 & 0.45 & 0.47 & 0.44 & 0.52 & 0.50 & 55 & 0.51 & 0.52 & 0.55 \\
\hline 1,04 & 0.99 & 1,08 & 1,07 & 1,09 & 1,13 & 1,19 & 1,33 & 1,27 & 1,42 & 1,52 & 1,54 & 1,66 & 1,71 & 1,75 & 1,78 & 1,81 & 1,91 & 2,00 & & 2,10 & 2,10 & 2,21 & 2,25 & 2,21 & & 2,31 & 2,35 & & 2,18 & 2,25 & 2,21 & 2,18 & 2,13 & 2,02 \\
\hline 100.30 & 100.84 & 101.02 & 100.87 & 100.23 & 100.35 & 101.17 & 100.84 & 101.71 & 100.85 & 100.53 & 100.37 & 100.28 & 101.09 & 100.12 & 100.45 & 100.41 & 100.27 & 101.37 & 100.95 & 101.26 & 100.28 & 100.05 & $\begin{array}{l}100.28 \\
\end{array}$ & 100.46 & 101.09 & 100.51 & 100.19 & 101.01 & 101.15 & 100.84 & 100.89 & 101.24 & 101.18 & 101.30 \\
\hline 2,996 & 2,984 & 2,993 & 2,989 & 2,954 & 2,966 & 2,994 & 2,955 & 2,987 & 2,983 & 2,951 & 2,962 & 2,955 & 2,972 & 2,968 & 2,959 & 2,969 & 2,967 & 2,987 & 2,994 & 2,994 & 2,955 & 2,969 & 2,970 & 2,956 & 2,982 & 2.957 & 2977 & 2.988 & 2.996 & 2968 & 2.976 & 2.985 & 2983 & 2.993 \\
\hline 1,963 & 1,975 & 1,963 & 1,971 & 2,004 & 1,991 & 1,982 & 1,993 & 1,996 & 1,985 & 2,004 & 1,999 & 2,003 & 1,995 & 2,000 & 1,996 & 2,005 & $\begin{array}{l}1,981 \\
1,961\end{array}$ & $\begin{array}{l}2,9810 \\
1,980\end{array}$ & 1,968 & 1,988 & $\begin{array}{l}1,984 \\
1,984\end{array}$ & 1,993 & 1,996 & 2,008 & 1,988 & 2,007 & 1,979 & $\begin{array}{l}1,980 \\
1,985\end{array}$ & $\begin{array}{l}1,963 \\
1,963\end{array}$ & 1,994 & & 1,9809 & 1,973 & $\begin{array}{l}1.970 \\
\end{array}$ \\
\hline 1,688 & 1,685 & 1,691 & 1,690 & 1,694 & 1,701 & 1,679 & 1,710 & 1,677 & 1,687 & 1,705 & 1,689 & 1,689 & 1,683 & 1,689 & 1,704 & 1,673 & 1,695 & 1,681 & 1,686 & $\begin{array}{l}1,653 \\
\end{array}$ & 1,709 & & 1,675 & 704 & 1,681 & 1,673 & 1,693 & & 1,691 & 1,677 & & 1,684 & 1,707 & 1,700 \\
\hline 1,260 & 1,272 & $\begin{array}{l}1,261 \\
1,201\end{array}$ & 1,254 & $\begin{array}{l}1,269 \\
1,22\end{array}$ & 1,261 & $\begin{array}{l}1,236 \\
\end{array}$ & 1,247 & 1,224 & $\begin{array}{l}1,227 \\
1,272\end{array}$ & $\begin{array}{l}1,233 \\
1,23\end{array}$ & $\begin{array}{l}1,229 \\
, 023\end{array}$ & 1,226 & $\begin{array}{l}1,209 \\
1,209\end{array}$ & 1,201 & 1,2 & $\begin{array}{l}1,202 \\
\end{array}$ & $\begin{array}{l}1,208 \\
1,202\end{array}$ & 1,179 & 1,1 & $\begin{array}{l}1,179 \\
1,199\end{array}$ & & & 1,1 & & & 1,183 & & & 1,1 & 81 & & 153 & 1,160 & 1,160 \\
\hline $\begin{array}{l}0.03 \\
0.085\end{array}$ & $\begin{array}{l}0.032 \\
0.08\end{array}$ & $\begin{array}{l}0.029 \\
0.088\end{array}$ & $\begin{array}{l}0.033 \\
0.037\end{array}$ & $\begin{array}{l}0.034 \\
0.0099\end{array}$ & $\begin{array}{l}0.026 \\
0.093\end{array}$ & $\begin{array}{l}0.028 \\
0.0996\end{array}$ & $\begin{array}{l}0.033 \\
0.019\end{array}$ & $\begin{array}{l}0.028 \\
0.102\end{array}$ & $\begin{array}{l}0.029 \\
0.115\end{array}$ & $\begin{array}{l}0.031 \\
0.124\end{array}$ & $\begin{array}{l}0.034 \\
0.126\end{array}$ & $\begin{array}{l}0.034 \\
0.134\end{array}$ & $\begin{array}{l}0.031 \\
0.139\end{array}$ & $\begin{array}{l}0.03 \\
0.144\end{array}$ & $\begin{array}{l}0.031 \\
0.1416\end{array}$ & $\begin{array}{l}0.032 \\
0.148\end{array}$ & $\begin{array}{l}0.035 \\
0.156\end{array}$ & $\begin{array}{l}0.034 \\
0.162\end{array}$ & $\begin{array}{l}0.031 \\
0.163\end{array}$ & $\begin{array}{l}0.029 \\
0.169\end{array}$ & $\begin{array}{l}0.038 \\
0.172\end{array}$ & $\begin{array}{l}0.033 \\
0.0183\end{array}$ & $\begin{array}{l}0.031 \\
0.185\end{array}$ & $\begin{array}{l}0.029 \\
0.181\end{array}$ & $\begin{array}{l}0.032 \\
0.187\end{array}$ & $\begin{array}{l}0.029 \\
0.189\end{array}$ & $\begin{array}{l}0.03 \\
0.193\end{array}$ & $\begin{array}{l}0.028 \\
0.188\end{array}$ & $\begin{array}{l}0.034 \\
0.177\end{array}$ & $\begin{array}{l}0.032 \\
0.1932\end{array}$ & $\begin{array}{l}0.036 \\
0.18\end{array}$ & $\begin{array}{l}0.033 \\
0.1977\end{array}$ & $\begin{array}{l}0.033 \\
0.173\end{array}$ & 0.035 \\
\hline 0.43 & 0.43 & 0.43 & 0.43 & 0.43 & 0.43 & 0.4 & 0.42 & 0.42 & & 0.42 & 0.42 & 04 & 0.42 & 042 & 0. & 0.42 & 0.4 & & 041 & 0.4 & 0.41 & 0.41 & 0.4 & 0.41 & 0.41 & 04 & & & 04 & 41 & & & 41 & 41 \\
\hline 0.55 & 0.55 & 0.55 & 0.55 & 0.5 & 0.55 & 0.5 & 0.5 & 0.55 & 0.5 & 0.5 & 0.5 & 0. & 0. & & 0. & 0.5 & & 0.5 & 0. & & & & & 0.5 & & 0. & & & & 0.55 & & & 0.56 & \\
\hline 0.41 & 0.41 & 0.41 & 0.41 & 0.41 & 0.41 & 0.41 & 0.40 & 0.40 & 0.40 & 0.40 & 0.40 & 0.40 & 0.40 & 0.39 & 0.39 & 0.39 & 0.39 & 0.39 & 0.38 & 0.39 & 0.38 & 0.38 & 0.38 & 0.38 & 0.38 & 0.39 & & 0.38 & 0.38 & 38 & 88 & 0.38 & .38 & .38 \\
\hline $\begin{array}{l}0.01 \\
0.03\end{array}$ & $\begin{array}{l}0.01 \\
0.03\end{array}$ & $\begin{array}{l}0.01 \\
0.03\end{array}$ & $\begin{array}{l}0.01 \\
0.03\end{array}$ & $\begin{array}{l}0.01 \\
0.03\end{array}$ & $\begin{array}{l}0.01 \\
0.03\end{array}$ & $\begin{array}{l}0.01 \\
0.03\end{array}$ & $\begin{array}{l}0.01 \\
0.04\end{array}$ & $\begin{array}{l}0.01 \\
0.03\end{array}$ & $\begin{array}{l}0.01 \\
0.04\end{array}$ & $\begin{array}{l}0.01 \\
0.04\end{array}$ & $\begin{array}{l}0.01 \\
0.04\end{array}$ & $\begin{array}{l}0.01 \\
0.04\end{array}$ & $\begin{array}{l}0.01 \\
0.05\end{array}$ & $\begin{array}{l}0.01 \\
0.05\end{array}$ & 0.05 & $\begin{array}{l}0.01 \\
0.05\end{array}$ & $\begin{array}{l}0.01 \\
0.05\end{array}$ & 0.05 & $\begin{array}{l}0.01 \\
0.06\end{array}$ & $\begin{array}{l}0.01 \\
0.06\end{array}$ & $\begin{array}{l}0.01 \\
0.06\end{array}$ & 0.06 & 0.06 & $\begin{array}{l}0.01 \\
0.066\end{array}$ & 0.06 & 0.06 & $\begin{array}{l}0.01 \\
0.066\end{array}$ & $\begin{array}{l}0.01 \\
0.06\end{array}$ & $\begin{array}{l}0.01 \\
0.06\end{array}$ & $\begin{array}{l}0.01 \\
0.06\end{array}$ & $\begin{array}{l}0.01 \\
0.06\end{array}$ & $\begin{array}{l}0.01 \\
0.06\end{array}$ & $\begin{array}{l}0.01 \\
0.06\end{array}$ & $\begin{array}{l}0.01 \\
0.05\end{array}$ \\
\hline
\end{tabular}




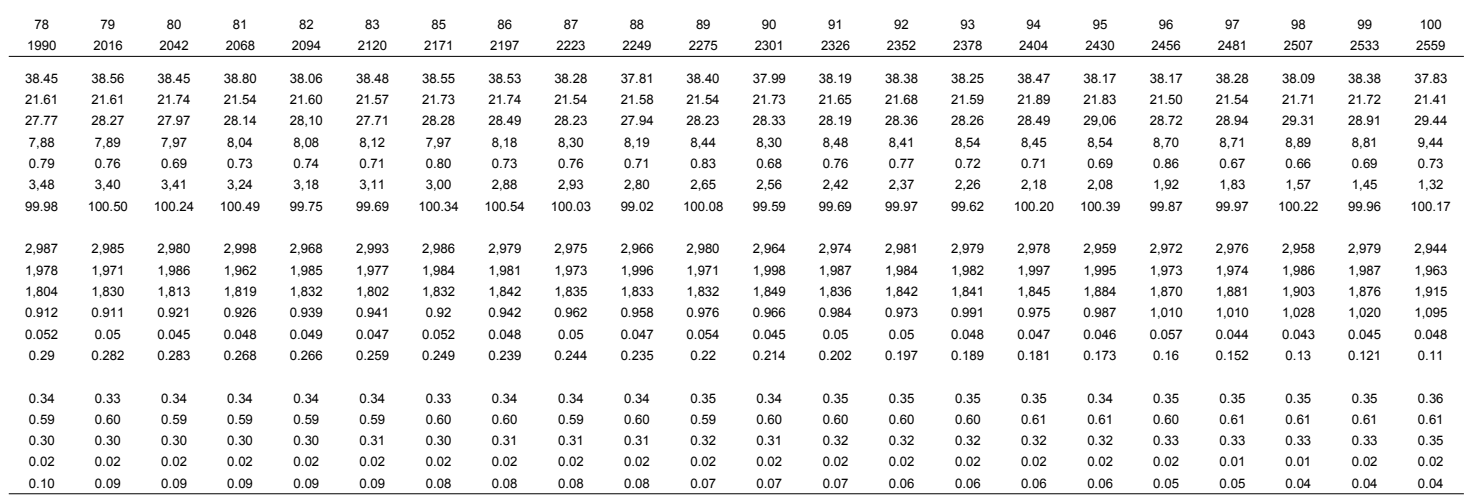

\begin{tabular}{|c|c|c|c|c|c|c|c|c|c|c|c|c|c|c|c|c|c|c|c|c|c|c|c|c|c|c|c|c|c|c|c|c|c|c|}
\hline $\begin{array}{r}87 \\
2559 \\
\end{array}$ & $\begin{array}{r}88 \\
2584 \\
2\end{array}$ & $\begin{array}{c}89 \\
2609 \\
\end{array}$ & $\begin{array}{r}919 \\
2659\end{array}$ & $\begin{array}{c}92 \\
2684 \\
\end{array}$ & $\begin{array}{c}93 \\
2709 \\
\end{array}$ & $\begin{array}{c}94 \\
2734\end{array}$ & $\begin{array}{c}95 \\
2759\end{array}$ & $\begin{array}{c}96 \\
2784 \\
\end{array}$ & $\begin{array}{c}97 \\
2809 \\
\end{array}$ & $\begin{array}{c}98 \\
2834 \\
2834\end{array}$ & $\begin{array}{c}99 \\
2859\end{array}$ & $\begin{array}{l}100 \\
2884 \\
2\end{array}$ & $\begin{array}{c}101 \\
2009 \\
2\end{array}$ & $\begin{array}{c}102 \\
2934 \\
2\end{array}$ & $\begin{array}{l}103 \\
2959 \\
2\end{array}$ & $\begin{array}{l}104 \\
2984 \\
2\end{array}$ & $\begin{array}{c}106 \\
3034 \\
3\end{array}$ & $\begin{array}{c}107 \\
3059 \\
\end{array}$ & $\begin{array}{c}108 \\
3084 \\
\end{array}$ & $\begin{array}{c}109 \\
3109 \\
\end{array}$ & $\begin{array}{c}110 \\
3134 \\
\end{array}$ & $\begin{array}{r}111 \\
3159 \\
\end{array}$ & $\begin{array}{l}113 \\
3200 \\
\end{array}$ & $\begin{array}{l}114 \\
3234\end{array}$ & $\begin{array}{r}115 \\
3259 \\
3\end{array}$ & $\begin{array}{l}1168 \\
3284\end{array}$ & $\begin{array}{r}1177 \\
3309 \\
\end{array}$ & $\begin{array}{l}120 \\
3385 \\
\end{array}$ & $\begin{array}{l}121 \\
3410\end{array}$ & $\begin{array}{l}122 \\
3435 \\
\end{array}$ & $\begin{array}{r}123 \\
3460 \\
3\end{array}$ & $\begin{array}{l}124 \\
3485\end{array}$ & $\begin{array}{r}125 \\
3510\end{array}$ & $\begin{array}{r}126 \\
3535\end{array}$ \\
\hline 38.5 & 38.66 & 38.51 & 38.42 & 38.64 & 38.95 & 38.41 & 38.99 & 40.14 & 37.30 & 38.17 & 38.12 & 38.74 & 38.83 & 38.74 & 38.84 & 39.08 & 39.26 & 39.11 & 38.81 & 38.99 & 38.59 & 38.59 & 38.83 & & 38.56 & 38.86 & 38.01 & 38.69 & 38.58 & 38.49 & 31.57 & 38.32 & & \\
\hline 21.73 & 21.55 & 21.69 & 21.53 & 21.97 & 21.80 & 21.59 & 21.61 & 22.30 & 20.75 & 21.79 & 21.35 & 21.58 & 21.45 & 21.66 & 21.61 & 21.70 & 21.62 & 21.79 & 21.75 & 21.61 & 21.78 & 21.72 & 21.56 & 21.78 & 21.89 & 21.62 & 21.38 & 21.84 & 22.00 & 21.73 & 17.73 & 21.75 & $\begin{array}{l}20.05 \\
22.15\end{array}$ & 21.85 \\
\hline 26.19 & 25.91 & 26.35 & 26.00 & 26.33 & 26,11 & 26.36 & 26.45 & 26.45 & 26,04 & 25.95 & 26.75 & 26.89 & 26.77 & 26.97 & 27.15 & 26.96 & 66 & 27.44 & 26.86 & 27.23 & 27.71 & 27.15 & 66 & 43 & 27.50 & 28,03 & & 23 & 28.27 & & 28.41 & 28.65 & .02 & 28.79 \\
\hline $\begin{array}{l}8,58 \\
0.52\end{array}$ & 8,42 & 8,44 & 8,55 & 8,45 & $\begin{array}{l}8,35 \\
056\end{array}$ & 8,36 & 8,24 & 8,18 & 8,82 & 7,56 & 8,63 & 8,40 & 8,38 & 8,36 & 8,37 & 8,08 & 8,24 & 8,24 & 8,43 & 8,43 & 8,42 & 8,47 & & 8,43 & 8,53 & 8,50 & & & 8,75 & & 8,32 & ,02 & .77 & 8,85 \\
\hline $\begin{array}{l}0.52 \\
4,61\end{array}$ & $\begin{array}{l}0.40 \\
4,52\end{array}$ & $\begin{array}{l}0.47 \\
4,49\end{array}$ & $\begin{array}{l}0.544 \\
4,47\end{array}$ & $\begin{array}{l}.0 .51 \\
4,39\end{array}$ & $\begin{array}{l}.0 .56 \\
4,35\end{array}$ & $\begin{array}{l}.0 .56 \\
4,35\end{array}$ & $\begin{array}{l}.0 .55 \\
4,36\end{array}$ & $\begin{array}{l}0.04 \\
4,36\end{array}$ & $\begin{array}{l}0.48 \\
4,34\end{array}$ & $\begin{array}{l}0.45 \\
4,26\end{array}$ & $\begin{array}{l}0.48 \\
4,46\end{array}$ & $\begin{array}{l}0.52 \\
4.23\end{array}$ & $\begin{array}{l}0.47 \\
4,17\end{array}$ & $\begin{array}{l}0.46 \\
4.06\end{array}$ & $\begin{array}{l}0.53 \\
4.07\end{array}$ & $\begin{array}{l}0.49 \\
4.04\end{array}$ & $\begin{array}{l}0.52 \\
3.887\end{array}$ & $\begin{array}{l}0.48 \\
3.86\end{array}$ & $\begin{array}{l}0.52 \\
3.76\end{array}$ & $\begin{array}{l}0.63 \\
3.448\end{array}$ & $\begin{array}{l}0.56 \\
3.65\end{array}$ & $\begin{array}{l}.0 .53 \\
3.30\end{array}$ & $\begin{array}{l}0.60 \\
3.26\end{array}$ & $\begin{array}{l}0.60 \\
3.21\end{array}$ & $\begin{array}{l}0.55 \\
3.04\end{array}$ & $\begin{array}{l}0.55 \\
2.97\end{array}$ & $\begin{array}{l}0.59 \\
2.79\end{array}$ & $\begin{array}{l}0.59 \\
2.30\end{array}$ & $\begin{array}{l}0.55 \\
209\end{array}$ & $\begin{array}{l}0.53 \\
1.87\end{array}$ & $\begin{array}{l}0.55 \\
1.59\end{array}$ & $\begin{array}{l}0.56 \\
1.43\end{array}$ & $\begin{array}{l}0.60 \\
1.36\end{array}$ & $\begin{array}{l}0.68 \\
1.29\end{array}$ \\
\hline 100.22 & 99.47 & 99.95 & 99.51 & $\begin{array}{l}1,503 \\
100.29\end{array}$ & $\begin{array}{l}1,300 \\
100.11\end{array}$ & 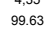 & 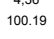 & $\begin{array}{l}\text { i,so } \\
101.97\end{array}$ & $\begin{array}{l}\text { r,s.74 } \\
97.74\end{array}$ & $\begin{array}{l}\text { i.t.6. } \\
98.17\end{array}$ & $\begin{array}{l}\begin{array}{r}4,6 \\
99.49\end{array}\end{array}$ & $\begin{array}{l}4,23 \\
100.37\end{array}$ & $\begin{array}{l}4,47 \\
100.07\end{array}$ & $\begin{array}{l}4,06 \\
100.24\end{array}$ & $\begin{array}{l}40,07 \\
100.57\end{array}$ & $\begin{array}{l}4,04 \\
100.34\end{array}$ & $\begin{array}{l}30,87 \\
100.17\end{array}$ & $\begin{array}{l}3,86 \\
100.92\end{array}$ & $\begin{array}{l}3,76 \\
100.14\end{array}$ & $\begin{array}{l}3.48 \\
100.37\end{array}$ & $\begin{array}{l}3,65 \\
100.70\end{array}$ & $\begin{array}{l}3,30 \\
99.76\end{array}$ & $\begin{array}{l}3,26 \\
100.59\end{array}$ & $\begin{array}{l}3,21 \\
100.23\end{array}$ & $\begin{array}{l}30.04 \\
100.06\end{array}$ & $\begin{array}{l}2,97 \\
100.52\end{array}$ & $\begin{array}{l}2,19 \\
99.52\end{array}$ & $\begin{array}{l}2,30 \\
100.16\end{array}$ & $\begin{array}{c}2,09 \\
100.23\end{array}$ & $\begin{array}{l}1,87 \\
99.96\end{array}$ & $\begin{array}{l}1,59 \\
88.16\end{array}$ & $\begin{array}{l}1,43 \\
99.73\end{array}$ & $\begin{array}{c}1,36 \\
100.76\end{array}$ & $\begin{array}{c}\text {, } 109 \\
100.03\end{array}$ \\
\hline 2,974 & 2,9966 & 2,977 & 2,982 & 2,975 & 2,99 & 2,981 & 3,005 & 3,0 & 2,959 & & & 2,987 & & & & & & & & & & & & & & & & & & & & & & \\
\hline 1,975 & 1,969 & 1,977 & $\begin{array}{l}1,969 \\
1,699\end{array}$ & 1,993 & 1,978 & 1,974 & 63 & 1,982 & 1,940 & 17 & & 1,961 & 1, & 1,9 & 1,961 & & & 1,9 & & & & & & & 1,9 & 1,96 & & & & & & & & \\
\hline $\begin{array}{l}1,688 \\
0.968\end{array}$ & 1,6 & 1,704 & 1,687 & 1,695 & 1,681 & 1,711 & 05 & 1,668 & 1,728 & 05 & 1,7 & 1,734 & 30 & 1,7 & 1,748 & 1, & 1, & 1,7 & 1,733 & & 1,7 & 1,75 & 1,78 & 1,770 & 1,77 & & & & & & & 1,861 & & 65 \\
\hline $\begin{array}{l}0.986 \\
0.034\end{array}$ & 0.9 & $\begin{array}{l}0.973 \\
0.031\end{array}$ & 0.9 & $\begin{array}{l}0.97 \\
0.033\end{array}$ & $\begin{array}{l}0.958 \\
0.036\end{array}$ & $\begin{array}{l}0.967 \\
0.037\end{array}$ & 0.947 & 0.919 & 1,043 & 0.885 & 1,002 & 0.966 & 0. & 0.9 & 0.96 & & 0. & 0.9 & 0.969 & & & 0.978 & & & & & & & & & & .044 & 005 & 21 \\
\hline $\begin{array}{l}0.034 \\
0.381\end{array}$ & 0.0375 & $\begin{array}{l}0.031 \\
0.372\end{array}$ & $\begin{array}{l}0.035 \\
0.372\end{array}$ & $\begin{array}{l}0.033 \\
0.362\end{array}$ & $\begin{array}{l}0.036 \\
0.359\end{array}$ & $\begin{array}{l}0.357 \\
0.362\end{array}$ & $\begin{array}{l}0.036 \\
0.36\end{array}$ & $\begin{array}{l}0.034 \\
0.353\end{array}$ & $\begin{array}{l}0.033 \\
0.369\end{array}$ & $\begin{array}{l}0.03 \\
0.358\end{array}$ & $\begin{array}{l}0.032 \\
0.347\end{array}$ & $\begin{array}{l}0.034 \\
0.35\end{array}$ & $\begin{array}{l}0.031 \\
0.345\end{array}$ & $\begin{array}{l}0.03 \\
0.335\end{array}$ & $\begin{array}{l}0.034 \\
0.336\end{array}$ & $\begin{array}{l}0.032 \\
0.332\end{array}$ & $\begin{array}{l}0.034 \\
0.319\end{array}$ & $\begin{array}{l}0.031 \\
0.317\end{array}$ & $\begin{array}{l}0.034 \\
0.314\end{array}$ & $\begin{array}{l}0.041 \\
0.287\end{array}$ & $\begin{array}{l}0.037 \\
0.371\end{array}$ & $\begin{array}{l}0.035 \\
0.274\end{array}$ & $\begin{array}{l}0.039 \\
0.269\end{array}$ & $\begin{array}{l}0.039 \\
0.266\end{array}$ & $\begin{array}{l}0.036 \\
0.256\end{array}$ & $\begin{array}{l}0.036 \\
0.245\end{array}$ & 0.039 & 0.038 & $\begin{array}{l}0.036 \\
0.173\end{array}$ & $\begin{array}{l}0.035 \\
0.155\end{array}$ & 0.042 & 0.037 & .039 & 0.045 \\
\hline 0.37 & & & & & & & & & & & & & & & & & & & & & & & & & & & & & & & & & & \\
\hline 0.55 & 0.5 & 0.5 & 0.55 & 0. & 0.5 & 0.56 & 0. & & 0.5 & & & 0.5 & & & & & & & & & & & & & & 0.59 & & & 0.60 & & & & & \\
\hline 0.32 & 0.32 & 0.32 & 0.32 & 0.32 & 0.32 & 0.31 & 0.31 & 0.3 & 0.33 & 0.30 & 0. & 0.3 & & & 0.3 & & & 0.31 & & & 0.31 & & 0.32 & 0.32 & & 0.3 & & 0. & 0.33 & & 0.32 & .34 & 33 & 0.34 \\
\hline 0.01 & 0.0 & 0.01 & & 0.01 & 0.01 & & 0.01 & & & 0.01 & & & & & 0.0 & & & & & & & & & & & & & & & & & & & 0.02 \\
\hline 0.12 & 0.12 & 0.12 & 0.12 & 0.12 & 0.12 & 0.12 & 0.12 & 0.12 & 0.12 & 0.12 & 0.11 & 0.11 & 0.11 & 0.11 & 0.11 & 0.11 & 0.11 & 0.10 & 0.10 & 0.09 & 0.10 & 0.09 & 0.09 & 0.09 & 0.08 & 0.08 & 0.08 & 0.06 & 0.06 & 0.05 & 0.04 & 0.04 & 0.04 & 0.04 \\
\hline
\end{tabular}




\begin{tabular}{|c|c|c|c|c|c|c|c|c|c|}
\hline $\begin{array}{l}717 \\
2047\end{array}$ & $\begin{array}{c}72 \\
2007\end{array}$ & $\begin{array}{c}73 \\
2088 \\
\end{array}$ & $\begin{array}{c}74 \\
2108\end{array}$ & $\begin{array}{c}75 \\
2129\end{array}$ & $\begin{array}{c}76 \\
2149 \\
\end{array}$ & $\begin{array}{c}77 \\
2170 \\
2\end{array}$ & $\begin{array}{c}78 \\
21900\end{array}$ & $\begin{array}{c}79 \\
2211\end{array}$ & $\begin{array}{c}80 \\
2231\end{array}$ \\
\hline 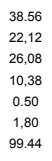 & $\begin{array}{l}39.54 \\
2.206 \\
2.651 \\
20.54 \\
0.54 \\
0.58 \\
1009 \\
109.93\end{array}$ & $\begin{array}{c}39.40 \\
21.94 \\
2621 \\
20.64 \\
10.54 \\
0.095 \\
1.63 \\
100.41\end{array}$ & $\begin{array}{l}38.82 \\
28.98 \\
26.18 \\
20.18 \\
10.73 \\
0.56 \\
1.48 \\
99.75\end{array}$ & $\begin{array}{l}39.29 \\
22.89 \\
22.48 \\
10.81 \\
0.57 \\
1.42 \\
100.46\end{array}$ & $\begin{array}{c}38.72 \\
22.72 \\
26.70 \\
10.77 \\
0.50 \\
1,36 \\
100.32\end{array}$ & $\begin{array}{c}39.64 \\
22.35 \\
26.56 \\
10,80 \\
0.48 \\
1,23 \\
1.107 .07\end{array}$ & $\begin{array}{c}39.70 \\
21.88 \\
26.35 \\
10.79 \\
0.055 \\
1,10 \\
100.37\end{array}$ & $\begin{array}{c}39.25 \\
22.00 \\
20.59 \\
10.87 \\
0.061 \\
1.16 \\
100.47\end{array}$ & $\begin{array}{c}39.40 \\
21.98 \\
28.31 \\
20.94 \\
10.94 \\
0.000 \\
1.14 \\
10.36\end{array}$ \\
\hline 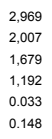 & 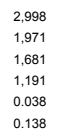 & $\begin{array}{l}3.000 \\
1,969 \\
1,1,698 \\
1,208 \\
0.038 \\
0.133\end{array}$ & $\begin{array}{l}2.978 \\
1,978 \\
1,679 \\
1,2727 \\
0.039 \\
0.0321\end{array}$ & $\begin{array}{l}2,9,938 \\
1,965 \\
1,1867 \\
1,227 \\
0.037 \\
0.116\end{array}$ & 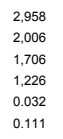 & $\begin{array}{l}2,995 \\
1,990 \\
1,6,87 \\
1,216 \\
0.031 \\
0.01 \\
0.1\end{array}$ & $\begin{array}{l}3.1018 \\
1,960 \\
1,675 \\
1,2222 \\
0.035 \\
0.099\end{array}$ & $\begin{array}{l}2,9899 \\
1,974 \\
1,1,494 \\
1,233 \\
0.039 \\
0.0995 \\
0.095\end{array}$ & $\begin{array}{l}2,9988 \\
1,971 \\
1,674 \\
1,240 \\
0.038 \\
0.093\end{array}$ \\
\hline $\begin{array}{l}0.42 \\
0.55 \\
0.39 \\
0.91 \\
0.05\end{array}$ & $\begin{array}{l}0.42 \\
0.55 \\
0.39 \\
0.01 \\
0.05\end{array}$ & $\begin{array}{l}0.42 \\
0.05 \\
0.04 \\
0.01 \\
0.01 \\
0.04\end{array}$ & $\begin{array}{l}0.42 \\
0.05 \\
0.40 \\
0.01 \\
0.04\end{array}$ & $\begin{array}{l}0.42 \\
0.55 \\
0.40 \\
0.01 \\
0.04 \\
0.04\end{array}$ & $\begin{array}{l}0.42 \\
0.56 \\
0.40 \\
0.40 \\
0.01 \\
0.04\end{array}$ & $\begin{array}{l}0.42 \\
0.06 \\
0.40 \\
0.01 \\
0.01 \\
0.03 \\
\end{array}$ & $\begin{array}{l}0.42 \\
0.55 \\
0.40 \\
0.01 \\
0.01 \\
0.03 \\
\end{array}$ & $\begin{array}{l}0.42 \\
0.55 \\
0.40 \\
0.01 \\
0.03 \\
\end{array}$ & $\begin{array}{l}0.43 \\
0.55 \\
.0 .41 \\
0.01 \\
0.01 \\
0.03\end{array}$ \\
\hline $\begin{array}{l}83 \\
2214\end{array}$ & $\begin{array}{c}84 \\
2239\end{array}$ & $\begin{array}{r}85 \\
2265 \\
2265\end{array}$ & $\begin{array}{l}86 \\
2290\end{array}$ & $\begin{array}{l}87 \\
2315 \\
23\end{array}$ & $\begin{array}{c}88 \\
2340 \\
23\end{array}$ & $\begin{array}{l}89 \\
22655\end{array}$ & $\begin{array}{l}90 \\
2091\end{array}$ & $\begin{array}{c}91 \\
2416\end{array}$ & $\begin{array}{c}92 \\
2441\end{array}$ \\
\hline 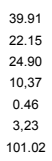 & $\begin{array}{c}39.06 \\
2.234 \\
25.10 \\
20.73 \\
0.53 \\
0.08 \\
300.83 \\
10.83\end{array}$ & 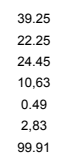 & $\begin{array}{l}39.25 \\
22.11 \\
25.33 \\
10.75 \\
0.43 \\
2.59 \\
100.46\end{array}$ & $\begin{array}{l}39.78 \\
22.33 \\
25.26 \\
20.81 \\
0.54 \\
2.43 \\
101.16\end{array}$ & 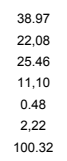 & $\begin{array}{c}39.58 \\
22.24 \\
25.53 \\
21.01 \\
0.04 \\
2.08 \\
100.98\end{array}$ & $\begin{array}{l}39.71 \\
22.13 \\
25.33 \\
21.12 \\
0.125 \\
.1 .75 \\
100.57\end{array}$ & $\begin{array}{c}39.53 \\
22.44 \\
25.41 \\
11,07 \\
0.046 \\
1,65 \\
100.55\end{array}$ & $\begin{array}{l}39.00 \\
22.18 \\
25.52 \\
11.26 \\
0.57 \\
1.39 \\
99.93\end{array}$ \\
\hline 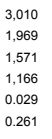 & 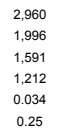 & 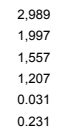 & 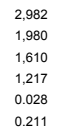 & $\begin{array}{l}2,9,962 \\
1,9.92 \\
1,5,51 \\
1.214 \\
0.034 \\
0.996\end{array}$ & $\begin{array}{l}2,967 \\
1,962 \\
1,621 \\
1,2600 \\
0.031 \\
0.181\end{array}$ & $\begin{array}{l}2,9999 \\
1,979 \\
1,612 \\
1,239 \\
0.035 \\
0.168 \\
0.168\end{array}$ & $\begin{array}{l}3.004 \\
1,973 \\
1.10303 \\
1.254 \\
0.033 \\
0.142\end{array}$ & $\begin{array}{l}2,2900 \\
2,000 \\
1,1,007 \\
1,248 \\
0.03 \\
0.134 \\
0.134\end{array}$ & 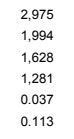 \\
\hline $\begin{array}{l}0.43 \\
0.52 \\
0.39 \\
0.01 \\
0.01 \\
0.09\end{array}$ & $\begin{array}{l}0.43 \\
0.52 \\
0.39 \\
0.01 \\
0.01 \\
0.08\end{array}$ & $\begin{array}{l}0.44 \\
0.52 \\
0.52 \\
0.04 \\
0.01 \\
0.08\end{array}$ & $\begin{array}{l}0.43 \\
0.53 \\
0.40 \\
0.01 \\
0.01 \\
0.07\end{array}$ & $\begin{array}{l}0.43 \\
0.52 \\
0.40 \\
0.01 \\
0.07 \\
\end{array}$ & $\begin{array}{l}0.44 \\
0.052 \\
0.04 \\
0.01 \\
0.01 \\
0.06\end{array}$ & $\begin{array}{l}0.44 \\
0.53 \\
0.41 \\
0.01 \\
0.01 \\
0.06\end{array}$ & $\begin{array}{l}0.44 \\
0.053 \\
.0 .41 \\
0.01 \\
0.05 \\
0.05\end{array}$ & $\begin{array}{l}0.44 \\
0.53 \\
0.41 \\
0.01 \\
0.04 \\
\end{array}$ & $\begin{array}{l}0.44 \\
0.53 \\
0.42 \\
0.01 \\
0.04 \\
\end{array}$ \\
\hline
\end{tabular}


\begin{tabular}{cccccccccc}
\hline 76 & 77 & 78 & 79 & 80 & 81 & 82 & 83 & 84 & 85 \\
1884 & 1904 & 1924 & 1943 & 1963 & 1983 & 2003 & 2023 & 2042 & 2062 \\
\hline 130
\end{tabular}

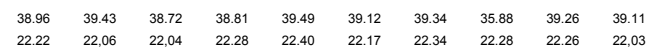
$\begin{array}{llllllllll}26.50 & 26.84 & 26.97 & 26.73 & 27.05 & 26.94 & 26.74 & 26,60 & 27.10 & 26.88 \\ 10.00 & 10.42 & 10.43 & 10.31 & 10.37 & 10.51 & 10.50 & 10.23 & 10.50 & 10.042\end{array}$

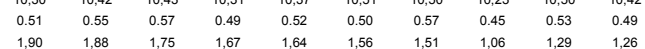
$\begin{array}{lllllllllll}10039 & 101.15 & 100.48 & 10029 & 101.47 & 100.80 & 100.99 & 96.50 & 100.93 & 10020\end{array}$

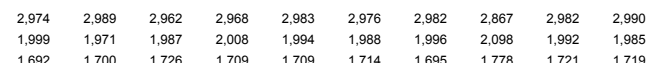

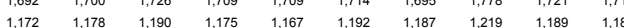
$\begin{array}{llllllllll}0.033 & 0.035 & 0.037 & 0.032 & 0.033 & 0.032 & 0.037 & 0.03 & 0.034 & 0.032\end{array}$

$\begin{array}{llllllllll}0.155 & 0.153 & 0.144 & 0.137 & 0.132 & 0.127 & 0.123 & 0.091 & 0.105 & 0.105\end{array}$

$\begin{array}{llllllllll}0.41 & 0.41 & 0.41 & 0.41 & 0.41 & 0.41 & 0.41 & 0.41 & 0.41 & 0.41 \\ 0.55 & 0.55 & 0.56 & 0.56 & 0.56 & 0.56 & 0.56 & 0.57 & 0.57 & 0.57\end{array}$

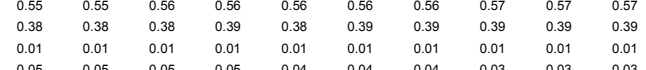

\begin{tabular}{llllllllll}
0.05 & 0.05 & 0.05 & 0.05 & 0.04 & 0.04 & 0.04 & 0.03 & 0.03 & 0.03 \\
\hline
\end{tabular}




\begin{tabular}{cc}
\hline & \\
\hline 127 & 128 \\
3561 & 3586 \\
\hline 3.84 & 38.54 \\
2.1 .80 & 21.87 \\
29.1 & 29.49 \\
8.75 & 8.48 \\
0.57 & 0.62 \\
1,33 & 1.27 \\
100.50 & 100.27 \\
2.995 & 2.985 \\
1,982 & 1,997 \\
$1,8.84$ & 1.10 \\
1,006 & 0.979 \\
0.0 .077 & 0.041 \\
0.11 & 0.105 \\
0.35 & 0.34 \\
0.62 & 0.63 \\
0.33 & 0.32 \\
0.01 & 0.01 \\
0.04 & 0.04 \\
\hline
\end{tabular}




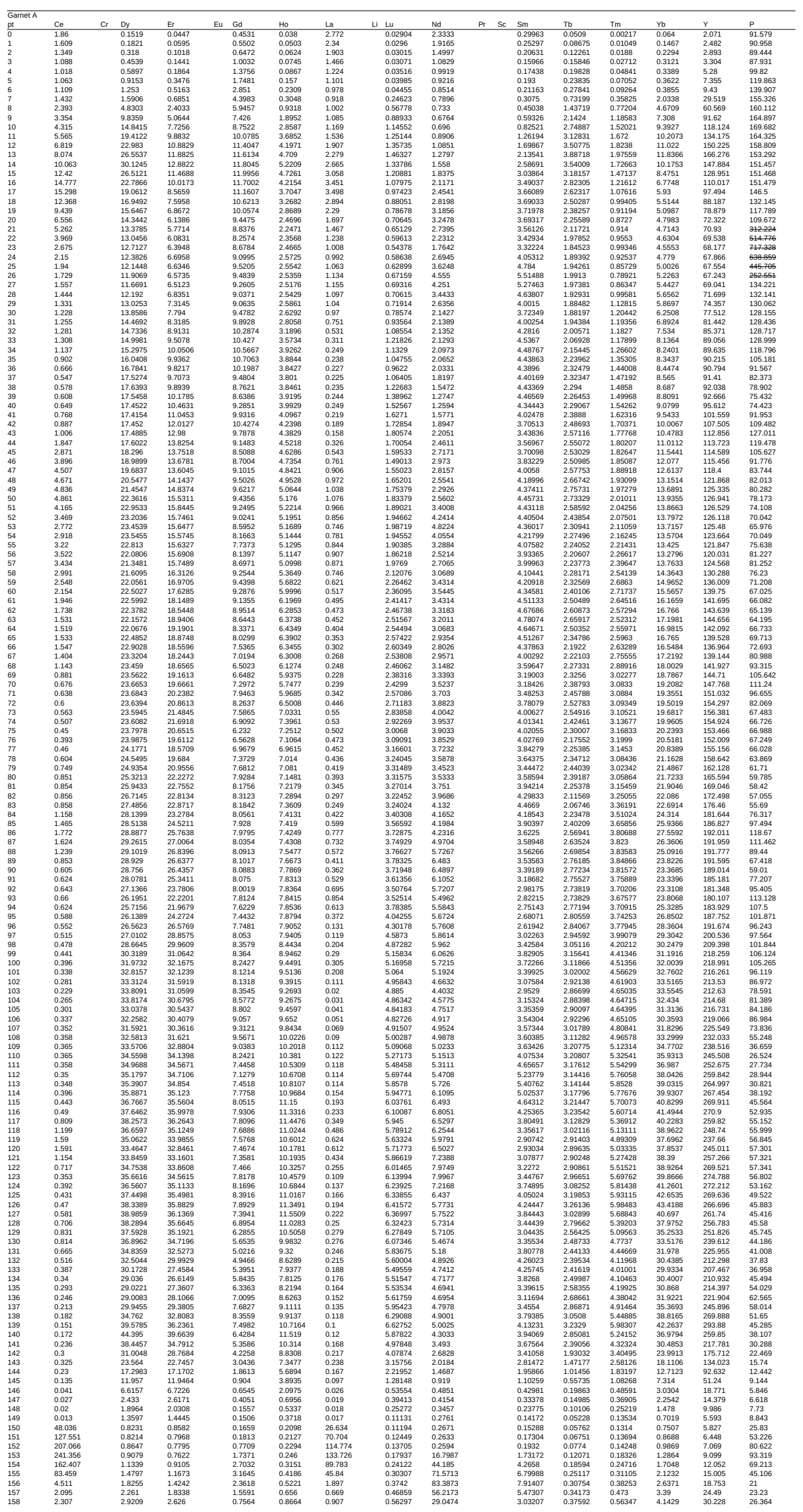




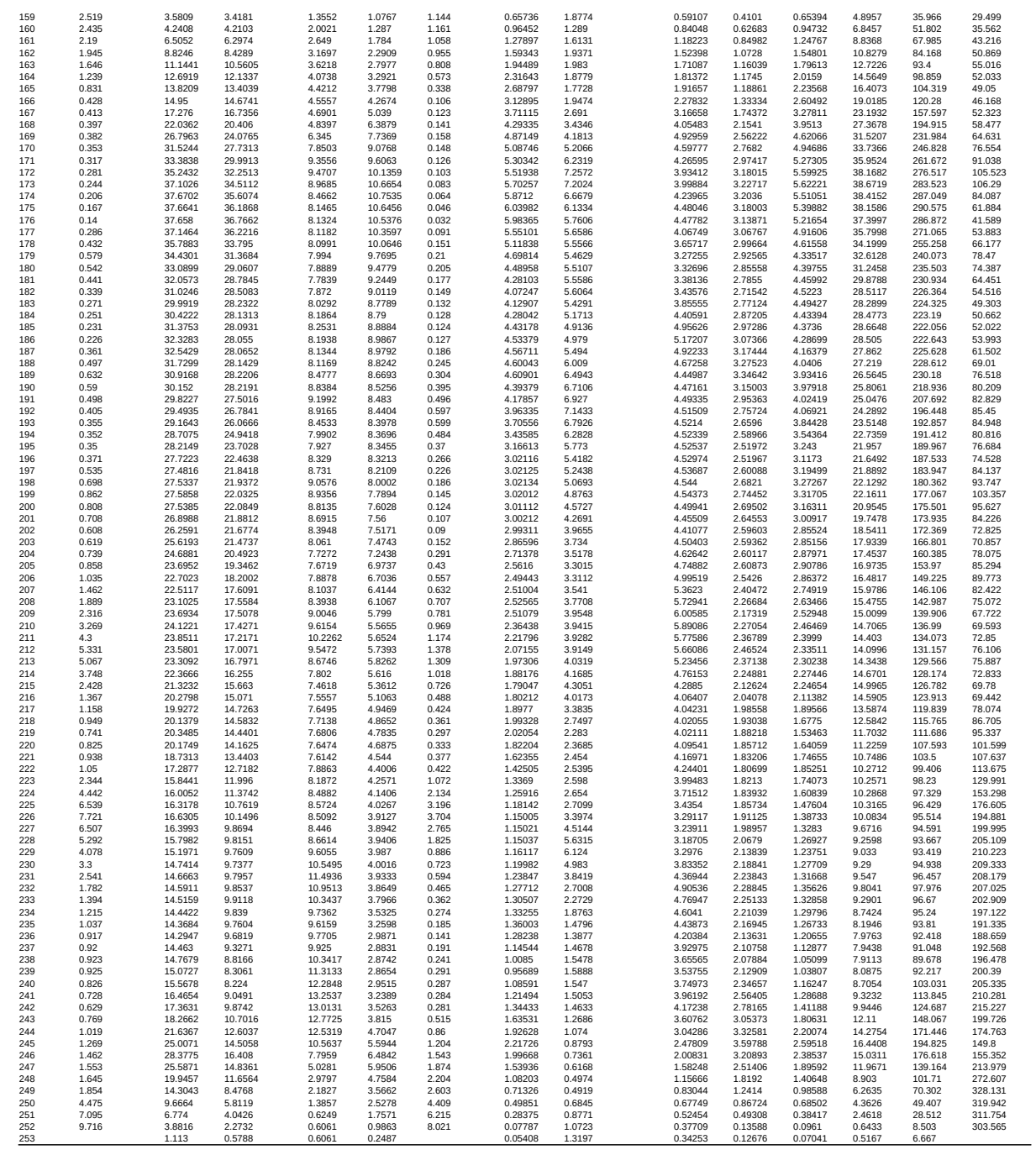




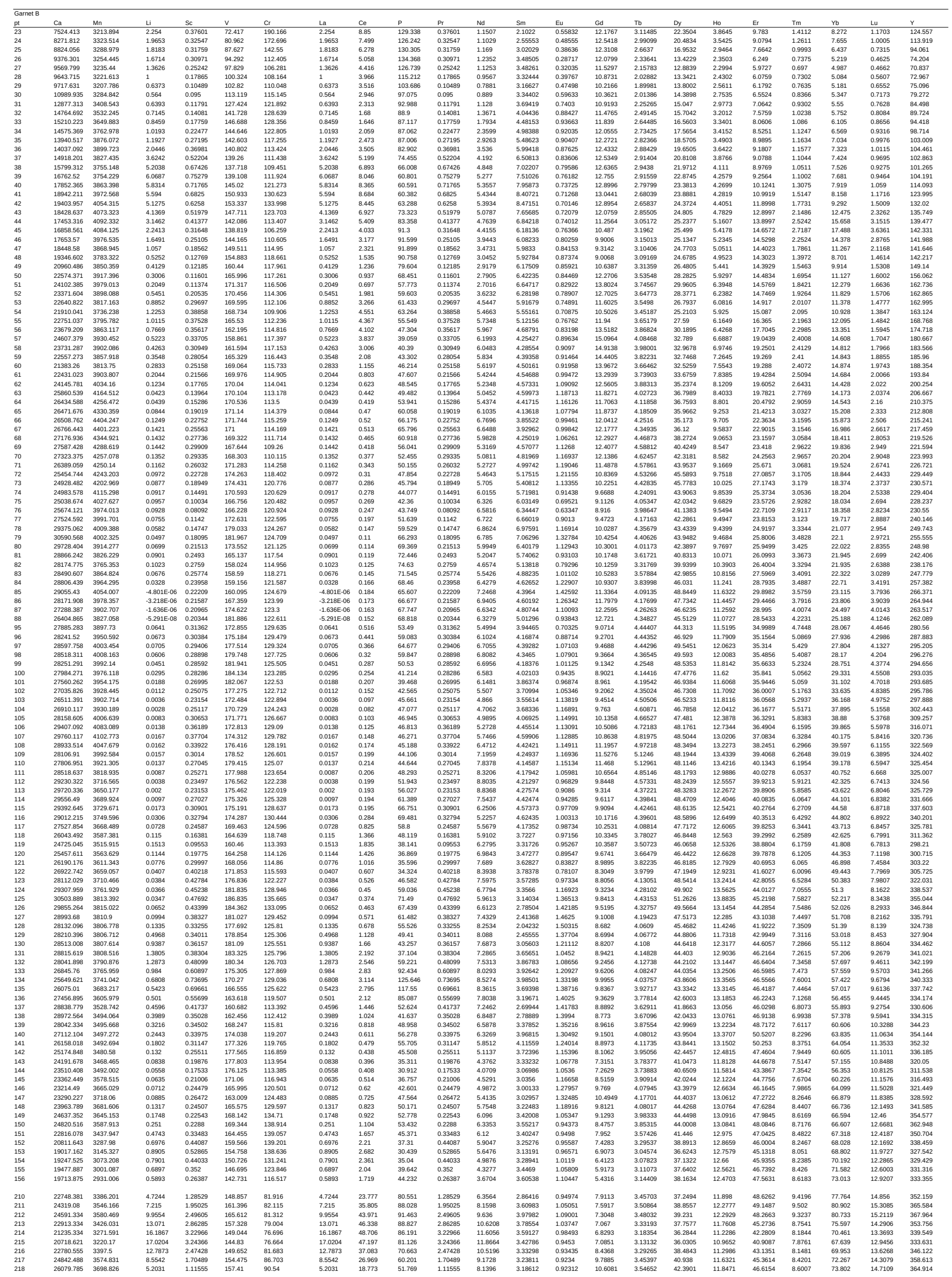




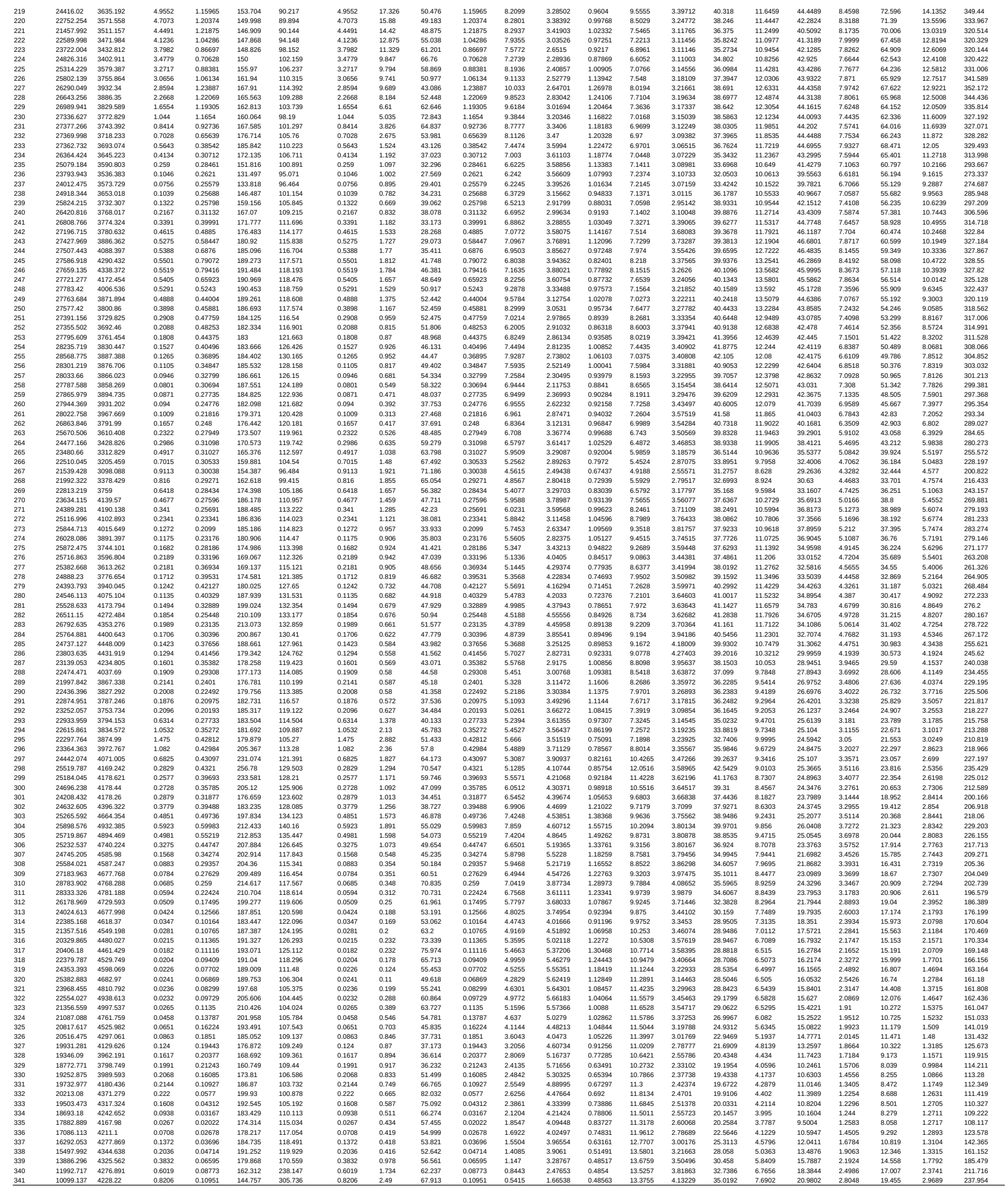




\begin{tabular}{|c|c|c|c|c|c|c|c|c|c|c|c|c|c|}
\hline 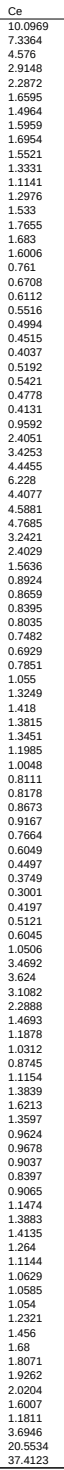 & 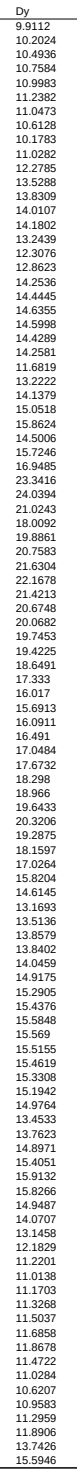 & 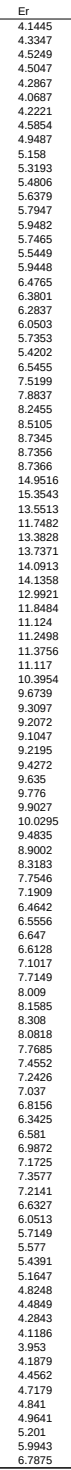 & 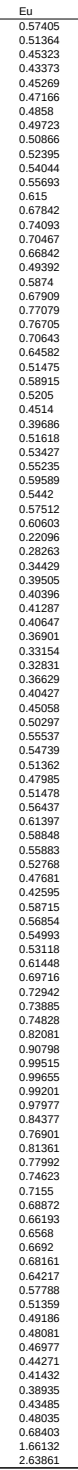 & 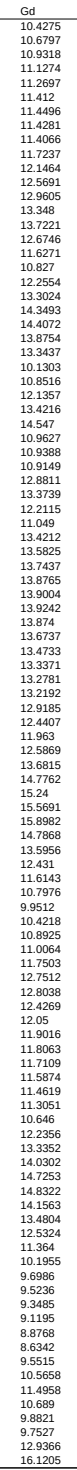 & 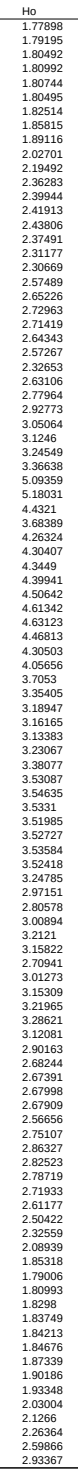 & 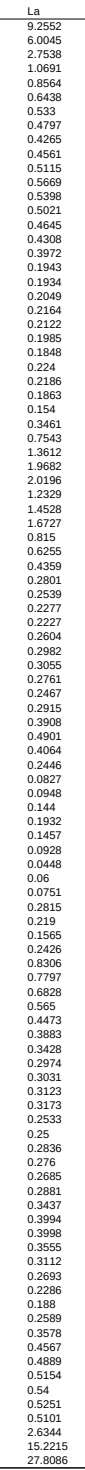 & 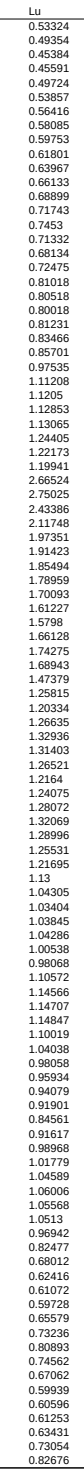 & 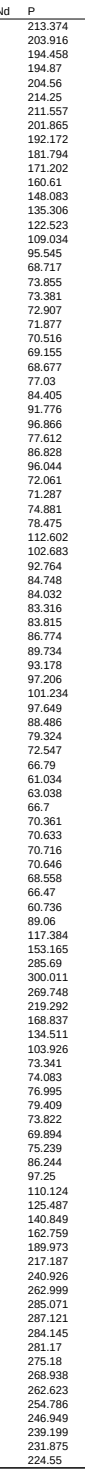 & 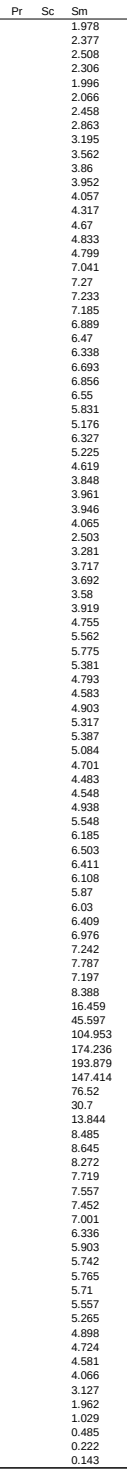 & 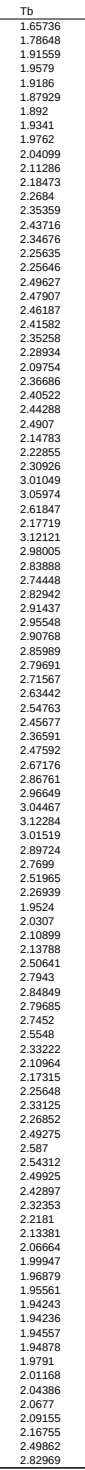 & 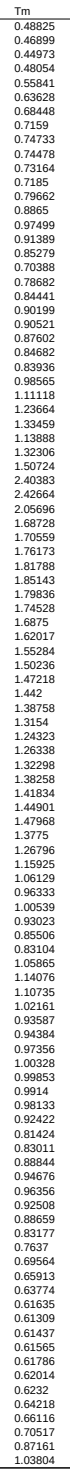 & 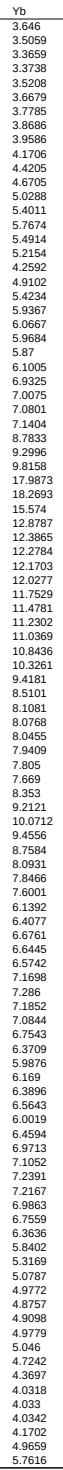 & 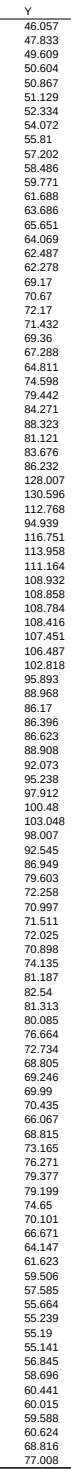 \\
\hline
\end{tabular}




\begin{tabular}{|c|c|c|c|c|c|c|c|c|c|c|c|c|c|c|c|c|c|c|c|c|c|}
\hline \multirow{2}{*}{ Monazite } & \multirow{2}{*}{ Location } & \multirow{2}{*}{ Analysis } & \multirow{2}{*}{$\begin{array}{l}\mathrm{Pb} \\
\mathrm{ppm}\end{array}$} & \multirow{2}{*}{$\begin{array}{l}\text { Th } \\
\text { ppm }\end{array}$} & \multirow{2}{*}{$\begin{array}{c}u \\
\mathrm{ppm}\end{array}$} & \multicolumn{7}{|c|}{ Measured ratios } & \multirow{2}{*}{ 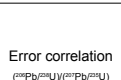 } & \multirow[b]{2}{*}{$\begin{array}{c}\text { Ages }(\mathrm{Ma}) \\
{ }_{20 \mathrm{P}} \mathrm{Pb} / 20 \mathrm{~Pb}\end{array}$} & \multirow[b]{2}{*}{$2 \sigma$ error } & \multirow[b]{2}{*}{ 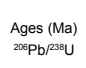 } & \multirow[b]{2}{*}{$2 \sigma$ error } & \multirow[b]{2}{*}{$\begin{array}{l}\text { Ages (Ma) } \\
20 \mathrm{Pp} p / 2 \mathrm{ss}\end{array}$} & \multirow[b]{2}{*}{$2 \sigma$ error } & \multirow[b]{2}{*}{ 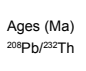 } & \multirow[b]{2}{*}{20 error } \\
\hline & & & & & & Th/U & $205 \mathrm{~Pb} / 23 \mathrm{G}$ & 20 error & $20 \mathrm{Pp} / 2 \mathrm{suU}$ & $2 \sigma$ error & $20 \mathrm{spp} p / 2=2 x h$ & $2 \sigma$ error & & & & & & & & & \\
\hline \multirow[t]{9}{*}{ м3 } & garnet corona ${ }^{-}$ & 07220410a & 4833 & 46728 & 655 & 71.4 & 0.37671 & 0.00970 & 6.24289 & 0.16316 & 0.10860 & 0.00256 & 0.99 & 1959 & 39 & 2061 & 45 & 2011 & 23 & 2084 & $47 \quad$ \\
\hline & & 08220410a & 4344 & 39967 & 1042 & 38.4 & 0.38194 & 0.00980 & 6.27779 & 0.16158 & 0.10996 & 0.00260 & 1.00 & 1945 & 38 & 2085 & 46 & 2015 & 23 & 2109 & 47 \\
\hline & & 09220410a & 4161 & 37465 & 1172 & 32.0 & 0.38172 & 0.00980 & 6.32455 & 0.16238 & 0.11067 & 0.00262 & 1.00 & 1959 & 38 & 2084 & 46 & 2022 & 23 & 2122 & 48 \\
\hline & & 10220410a* & 4016 & 35987 & 1141 & 31.6 & 0.38382 & 0.00986 & 6.41352 & 0.16532 & 0.11107 & 0.00262 & 1.00 & 1974 & 38 & 2094 & 46 & 2034 & 23 & 2129 & 48 \\
\hline & & 11220410a & 3926 & 37703 & 685 & 55.0 & 0.37378 & 0.00962 & 6.16346 & 0.16048 & 0.10803 & 0.00256 & 0.99 & 1951 & 39 & 2047 & 45 & 1999 & 23 & 2073 & 47 \\
\hline & & 12220410a & 4124 & 38152 & 1113 & 34.3 & 0.37153 & 0.00954 & 6.12666 & 0.15802 & 0.10854 & 0.00258 & 1.00 & 1951 & 38 & 2037 & 45 & 1994 & 23 & 2083 & 47 \\
\hline & & 13220410a & 4015 & 37077 & 1133 & 32.7 & 0.36773 & 0.00944 & 5.97349 & 0.15428 & 0.10842 & 0.00256 & 0.99 & 1924 & 38 & 2019 & 44 & 1972 & 22 & 2081 & 47 \\
\hline & & 14220410a & 3877 & 37583 & 630 & 59.6 & 0.37587 & 0.00968 & 5.96853 & 0.15712 & 0.10752 & 0.00254 & 0.98 & 1883 & 40 & 2057 & 45 & 1971 & 23 & 2064 & 47 \\
\hline & & 17220410a & 1485 & 60815 & 1145 & 53.1 & 0.37460 & 0.00966 & 6.20153 & 0.16430 & 0.10731 & 0.00254 & 0.97 & 1958 & 40 & 2051 & 45 & 2005 & 23 & 2060 & 46 \\
\hline \multirow[t]{7}{*}{ M1 } & matrix & 19220410a & 4190 & 40269 & 614 & 65.5 & 0.38301 & 0.00992 & 6.68575 & 0.17976 & 0.10918 & 0.00260 & 0.96 & 2052 & 40 & 2090 & 46 & 2071 & 24 & 2094 & 47 \\
\hline & & 20220410a & 3243 & 30781 & 422 & 72.9 & 0.38657 & 0.01004 & 6.63376 & 0.18068 & 0.10911 & 0.00258 & 0.95 & 2021 & 41 & 2107 & 47 & 2064 & 24 & 2093 & 47 \\
\hline & & 21220410a & 3512 & 33630 & 373 & 90.1 & 0.37961 & 0.00996 & 6.50656 & 0.18426 & 0.10740 & 0.00254 & 0.93 & 2019 & 44 & 2075 & 47 & 2047 & 25 & 2062 & 47 \\
\hline & & 222220410a & 3392 & 33417 & 242 & 137.9 & 0.37192 & 0.00966 & 6.31423 & 0.17258 & 0.10686 & 0.00254 & 0.95 & 2002 & 42 & 2038 & 45 & 2020 & 24 & 2052 & 46 \\
\hline & & 25220410a & 2645 & 25527 & 396 & 64.5 & 0.37782 & 0.00990 & 6.32737 & 0.18052 & 0.10825 & 0.00258 & 0.92 & 1978 & 44 & 2066 & 46 & 2022 & 25 & 2078 & 47 \\
\hline & & 26220410a & 2514 & 24739 & 288 & 85.9 & 0.37138 & 0.00972 & 6.20212 & 0.17560 & 0.10655 & 0.00254 & 0.92 & 1973 & 44 & 2036 & 46 & 2005 & 25 & 2046 & 46 \\
\hline & & $28220410 a$ & 2666 & 25695 & 381 & 67.5 & 0.37365 & 0.00970 & 6.18806 & 0.17102 & 0.10776 & 0.00256 & 0.94 & 1958 & 42 & 2047 & 46 & 2003 & 24 & 2069 & 47 \\
\hline M13 & garnet corona & $29220410 \mathrm{a}^{*}$ & 2540 & 25792 & 317 & 81.3 & 0.36243 & 0.00946 & 5.86449 & 0.16538 & 0.10310 & 0.00246 & 0.93 & 1917 & 44 & 1994 & 45 & 1956 & 24 & 1983 & 45 \\
\hline & & 30220410a & 2554 & 25329 & 278 & 91.2 & 0.37082 & 0.00970 & 6.05440 & 0.17250 & 0.10600 & 0.00252 & 0.92 & 1933 & 45 & 2033 & 46 & 1984 & 25 & 2036 & 46 \\
\hline & & 33220410a & 2989 & 29611 & 301 & 98.5 & 0.37283 & 0.00976 & 6.30146 & 0.18120 & 0.10695 & 0.00254 & 0.91 & 1995 & 45 & 2043 & 46 & 2019 & 25 & 2054 & 46 \\
\hline & & 36220410a & 2072 & 20720 & 170 & 121.7 & 0.37748 & 0.01000 & 6.70199 & 0.20022 & 0.10664 & 0.00254 & 0.89 & 2082 & 47 & 2065 & 47 & 2073 & 26 & 2048 & 46 \\
\hline M12 & cordierite & $42220410 \mathrm{a}$ & 3019 & 30710 & 319 & 96.3 & 0.36237 & 0.00950 & 5.96332 & 0.17478 & 0.10359 & 0.00248 & 0.89 & 1947 & 46 & 1993 & 45 & 1971 & 25 & 1992 & 45 \\
\hline & & $43220410 \mathrm{a}$ & 3504 & 34976 & 290 & 120.4 & 0.38431 & 0.01006 & 6.38088 & 0.18676 & 0.10619 & 0.00254 & 0.89 & 1963 & 46 & 2096 & 47 & 2030 & 26 & 2040 & 46 \\
\hline M7 & inclusion in & $07220410 \mathrm{~b}$ & 3436 & 29255 & 1805 & 16.2 & 0.38007 & 0.00978 & 6.48405 & 0.17972 & 0.10598 & 0.00256 & 0.93 & 2011 & 42 & 2077 & 46 & 2044 & 24 & 2036 & 47 \\
\hline & garnet & $08220410 \mathrm{~b}$ & 3488 & 28368 & 1978 & 14.3 & 0.38398 & 0.00988 & 6.53893 & 0.18158 & 0.10883 & 0.00264 & 0.93 & 2008 & 42 & 2095 & 46 & 2051 & 24 & 2088 & 48 \\
\hline & & $09220410 \mathrm{~b}$ & 10440 & 79551 & 3740 & 21.3 & 0.38353 & 0.00986 & 6.53198 & 0.18114 & 0.10899 & 0.00264 & 0.93 & 2008 & 42 & 2093 & 46 & 2050 & 24 & 2001 & 48 \\
\hline & & $10220410 \mathrm{~b}$ & 11282 & 84742 & 4281 & 19.8 & 0.38280 & 0.00984 & 6.50028 & 0.18084 & 0.10919 & 0.00264 & 0.92 & 2003 & 42 & 2089 & 46 & 2046 & 24 & 2095 & 48 \\
\hline M6 & garnet corona & $11220410 \mathrm{~b}^{*}$ & 8361 & 67660 & 3148 & 21.5 & 0.36139 & 0.00932 & 6.06015 & 0.17016 & 0.10287 & 0.00248 & 0.92 & 1980 & 43 & 1989 & 44 & 1985 & 24 & 1979 & 46 \\
\hline & & $15220410 \mathrm{~b}^{*}$ & 3654 & 31896 & 1926 & 16.6 & 0.36765 & 0.00948 & 6.25963 & 0.17874 & 0.10388 & 0.00252 & 0.90 & 1995 & 55 & 1954 & 46 & 1974 & 29 & 1998 & 46 \\
\hline & & $16220410 \mathrm{~b}$ & 4026 & 35564 & 1642 & 21.7 & 0.37599 & 0.00970 & 6.31429 & 0.18170 & 0.10700 & 0.00258 & 0.90 & 2007 & 44 & 2058 & 45 & 2020 & 25 & 2055 & 47 \\
\hline M8 & garnet corona & $17220410 \mathrm{~b}^{*}$ & 23039 & 42916 & 5258 & 8.2 & 0.35764 & 0.00924 & 5.89449 & 0.17014 & 0.10261 & 0.00248 & 0.90 & 1983 & 44 & 1971 & 44 & 1960 & 25 & 1974 & 46 \\
\hline & & $18220410 \mathrm{~b}^{*}$ & 23781 & $\begin{array}{l}44063 \\
5009\end{array}$ & 5234 & 8.4 & 0.36269 & 0.00938 & 6.02281 & 0.17498 & 0.10366 & 0.00250 & 0.89 & 1963 & 45 & 1995 & 44 & 1979 & 25 & 1994 & 46 \\
\hline M4 & garnet corona & $\begin{array}{l}192220410 \mathrm{~b} \\
202020410 \mathrm{~b}\end{array}$ & 29453 & $\begin{array}{l}52048 \\
56458\end{array}$ & 7093 & $\begin{array}{l}7.3 \\
516\end{array}$ & 0.36922 & $\begin{array}{l}0.00954 \\
0.00986\end{array}$ & $\begin{array}{l}6.19700 \\
6.42208\end{array}$ & 0.18046 & $\begin{array}{l}0.10588 \\
0.10781\end{array}$ & 0.00256 & 0.89 & $\begin{array}{l}1982 \\
2029\end{array}$ & ${ }^{45}$ & 2026 & 45 & 2004 & $\begin{array}{l}25 \\
{ }_{27}\end{array}$ & 2034 & 47 \\
\hline M11 & $\begin{array}{l}\text { garnet corona } \\
\text { garnet corona }\end{array}$ & $\begin{array}{l}20220410 \mathrm{~b} \\
2322040 \mathrm{~b}\end{array}$ & $\begin{array}{l}26864 \\
4497\end{array}$ & $\begin{array}{l}56458 \\
36576\end{array}$ & $\begin{array}{l}1094 \\
1946\end{array}$ & $\begin{array}{l}51.6 \\
18.8\end{array}$ & $\begin{array}{l}0.37686 \\
0.36793\end{array}$ & $\begin{array}{l}0.00086 \\
0.00954\end{array}$ & $\begin{array}{l}6.422208 \\
6.28375\end{array}$ & $\begin{array}{l}0.19650 \\
0.18906\end{array}$ & $\begin{array}{l}0.10781 \\
0.10644\end{array}$ & $\begin{array}{l}0.00260 \\
0.00258\end{array}$ & $\begin{array}{l}0.86 \\
0.86\end{array}$ & $\begin{array}{l}2009 \\
2013\end{array}$ & $\begin{array}{l}48 \\
47\end{array}$ & $\begin{array}{l}2002 \\
2020\end{array}$ & $\begin{array}{l}46 \\
45 \\
45\end{array}$ & $\begin{array}{l}2035 \\
2016\end{array}$ & ${ }^{27}$ & $\begin{array}{l}2069 \\
2044\end{array}$ & $\begin{array}{l}48 \\
47\end{array}$ \\
\hline & & $24220410 \mathrm{~b}$ & 3815 & 33360 & 1753 & $\begin{array}{l}19.0 \\
19.0\end{array}$ & 0.36885 & 0.00958 & 6.29805 & 0.19142 & 0.10618 & 0.00256 & 0.85 & 2012 & $\begin{array}{l}47 \\
48\end{array}$ & 2024 & $\begin{array}{l}45 \\
45\end{array}$ & $\begin{array}{l}2016 \\
2018\end{array}$ & $\begin{array}{l}26 \\
27\end{array}$ & $\begin{array}{l}2044 \\
2040\end{array}$ & $\begin{array}{l}47 \\
47\end{array}$ \\
\hline & & $25220410 \mathrm{~b}$ & 69383 & 31589 & 1255 & 25.2 & 0.38074 & 0.00990 & 6.44913 & 0.19800 & 0.10862 & 0.00262 & & 1998 & 48 & 2080 & 46 & 2039 & 27 & 2084 & $\begin{array}{l}41 \\
48\end{array}$ \\
\hline & & $26220410 \mathrm{~b}$ & 68800 & 32354 & 981 & 33.0 & 0.38095 & 0.00994 & 6.48009 & 0.20158 & 0.10798 & 0.00262 & 0.84 & 2006 & 49 & 2081 & & 2043 & 27 & 2073 & $\begin{array}{l}48 \\
48\end{array}$ \\
\hline M2 & matrix & $27220410 \mathrm{~b}$ & 119897 & 60223 & 618 & 97.4 & 0.36992 & 0.00972 & 6.19893 & 0.19768 & 0.10755 & 0.00260 & 0.82 & 1979 & 51 & 2029 & 46 & 2004 & 28 & 2065 & 47 \\
\hline & & $28220410 \mathrm{~b}$ & 104613 & 51524 & 708 & 72.7 & 0.37416 & 0.00980 & 6.32158 & 0.20144 & 0.10851 & 0.00262 & 0.82 & 1994 & 51 & 2049 & 46 & 2022 & 28 & 2082 & 48 \\
\hline
\end{tabular}

\begin{tabular}{|c|c|c|c|c|c|c|c|c|c|c|c|c|c|c|c|c|c|c|}
\hline \multirow[b]{2}{*}{ Ziron } & \multirow[b]{2}{*}{ Analysis } & \multirow[b]{2}{*}{$\begin{array}{c}\mathrm{Pb} \\
\mathrm{ppm}\end{array}$} & \multirow[b]{2}{*}{$\begin{array}{c}\text { Th } \\
\text { ppm }\end{array}$} & \multirow[b]{2}{*}{$\begin{array}{c}u \\
\mathrm{ppm}\end{array}$} & \multicolumn{8}{|c|}{ Measured ratios } & \multirow[b]{2}{*}{$\begin{array}{l}\text { Ages (Ma) } \\
\text { arpapespos }\end{array}$} & \multirow[b]{2}{*}{ 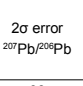 } & \multirow[b]{2}{*}{ 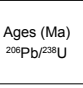 } & \multirow[b]{2}{*}{$\begin{array}{l}2 \sigma \text { error } \\
2 \sigma\end{array}$} & \multirow[b]{2}{*}{$\begin{array}{l}\text { Ages (Ma) } \\
\text { arppof } / 23 \mathrm{su}\end{array}$} & \multirow[b]{2}{*}{$\begin{array}{c}2 \sigma \text { error } \\
2 \sigma\end{array}$} \\
\hline & & & & & Th/U & ${ }^{207 \mathrm{Pp} / 200 \mathrm{~Pb}}$ & $2 \sigma$ & 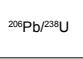 & $2 \sigma$ & 2rpp/asu & $2 \sigma$ & $\begin{array}{l}\text { Error correlation } \\
\text { (ump }\end{array}$ & & & & & & \\
\hline & $\begin{array}{l}05150311 \mathrm{~b} \\
0.615311 \mathrm{~b}\end{array}$ & $\begin{array}{l}105 \\
59\end{array}$ & 38 & 274 & 0.1 & 0.12805 & $\begin{array}{ll}0.00274 \\
0.0204\end{array}$ & 0.37178 & 0.00782 & $\begin{array}{l}6.56623 \\
67625\end{array}$ & 0.1456 & 0.95 & 2071 & 38 & 2038 & 37 & 2055 & 20 \\
\hline & $\begin{array}{l}06150311 \mathrm{~b} \\
071503111 \mathrm{~b}\end{array}$ & 59 & ${ }^{22}$ & $\begin{array}{l}147 \\
118\end{array}$ & 0.1 & 0.12887 & 0.00284 & 0.38044 & 0.00794 & 6.76245 & 0.15232 & 0.93 & 2083 & 39 & 2078 & 37 & 2081 & 20 \\
\hline & $\begin{array}{l}0.7550311 \mathrm{~b} \\
0.9150311 \mathrm{~b}\end{array}$ & $\begin{array}{l}51 \\
73\end{array}$ & 28 & $\begin{array}{l}118 \\
209\end{array}$ & $\begin{array}{l}0.1 \\
0.1\end{array}$ & $\begin{array}{l}0.13706 \\
0.13477\end{array}$ & $\begin{array}{l}0.0031 \\
0.00306\end{array}$ & $\begin{array}{l}0.40551 \\
0.35447\end{array}$ & $\begin{array}{l}0.0084 \\
0.00716\end{array}$ & $\begin{array}{l}7.66637 \\
6.58908\end{array}$ & $\begin{array}{l}0.17426 \\
0.1436\end{array}$ & $\begin{array}{l}0.91 \\
0.90\end{array}$ & $\begin{array}{l}2190 \\
2161\end{array}$ & 39 & 2194 & 39 & 2193 & 20 \\
\hline & $\begin{array}{l}05150303110 \\
05150\end{array}$ & 111 & 123 & 239 & $\begin{array}{l}0.1 \\
0.5\end{array}$ & $\begin{array}{l}0.1344 / 1 \\
0.14136\end{array}$ & $\begin{array}{l}0.00306 \\
0.00312\end{array}$ & $\begin{array}{l}0.3544 r \\
0.40488\end{array}$ & $\begin{array}{l}0.00016 \\
0.00864\end{array}$ & $\begin{array}{l}6.589088 \\
7.89667\end{array}$ & $\begin{array}{l}0.14436 \\
0.1802\end{array}$ & $\begin{array}{l}0.90 \\
0.94\end{array}$ & $\begin{array}{l}2161 \\
2244\end{array}$ & $\begin{array}{l}39 \\
38\end{array}$ & $\begin{array}{l}1956 \\
2192\end{array}$ & ${ }_{40}^{34}$ & $\begin{array}{l}2008 \\
2219\end{array}$ & 21 \\
\hline & 06150311c & 49 & 29 & 139 & 0.2 & 0.1281 & 0.0034 & 0.32557 & 0.00706 & 5.75444 & 0.15276 & 0.82 & 2072 & 46 & 1817 & 34 & 1940 & 23 \\
\hline & $07150311 \mathrm{c}$ & 18 & 21 & 45 & 0.5 & 0.12554 & 0.00314 & 0.35073 & 0.00738 & 6.07523 & 0.15118 & 0.85 & 2036 & 44 & 1938 & 35 & 1987 & 22 \\
\hline & $08150311 \mathrm{C}$ & 57 & 28 & 154 & 0.2 & 0.12777 & 0.00302 & 0.37744 & 0.00772 & 6.65346 & 0.1548 & 0.88 & 2068 & 41 & 2064 & 36 & 2067 & 21 \\
\hline & $09150311 \mathrm{c}$ & 135 & 123 & 301 & 0.4 & 0.14845 & 0.0035 & 0.41452 & 0.00832 & 8.48907 & 0.19336 & 0.88 & 2328 & 40 & 2236 & 38 & 2285 & 21 \\
\hline & $10150311 \mathrm{c}$ & 91 & 40 & 239 & 0.2 & 0.12904 & 0.00312 & 0.38156 & 0.00756 & 6.79173 & 0.15614 & 0.86 & 2085 & 42 & 2084 & 35 & 2085 & 20 \\
\hline & 03150311d & 320 & 344 & 813 & 0.4 & 0.12775 & 0.0028 & 0.35262 & 0.00772 & 6.21268 & 0.14532 & 0.94 & 2067 & 38 & 1947 & 37 & 2006 & 20 \\
\hline & 04150311d & 229 & 182 & 549 & 0.3 & 0.12836 & 0.00288 & 0.37412 & 0.00808 & 6.62303 & 0.1552 & 0.92 & 2076 & 39 & 2049 & 38 & 2062 & 21 \\
\hline & 05150311d & 151 & 80 & 363 & 0.2 & 0.12791 & 0.00294 & 0.37889 & 0.00806 & 6.68385 & 0.15756 & 0.90 & 2069 & 40 & 2071 & 38 & 2071 & 21 \\
\hline & 06150311d & 170 & 153 & 391 & 0.4 & 0.12838 & 0.00316 & 0.37536 & 0.00794 & 6.64614 & 0.16414 & 0.86 & 2076 & 43 & 2055 & 37 & 2066 & 22 \\
\hline
\end{tabular}




\section{APPENDIX S1 : Trace element LA-ICP-MS analytical procedure}

LA-ICP-MS trace element maps were acquired using a Resonetics M-50-LR $193 \mathrm{~nm}$ excimer laser coupled to an Agilent 7700x Quadrupole ICP-MS housed at Adelaide Microscopy, University of Adelaide. Instrument conditions and mapping protocols similar to that employed in this study are outlined by (Raimondo et al., 2017). Mapping was performed on standard $30 \mu \mathrm{m}$-thick polished thin sections by ablating a series of parallel rasters across the sample surface to form a square or rectangular grid. A beam diameter of $16 \mu \mathrm{m}$ coupled with a laser repetition rate of $10 \mathrm{~Hz}$ produced an energy density of $\sim 3.5 \mathrm{~J} / \mathrm{cm}^{2}$ at the target, and a scan speed of $22 \mu \mathrm{m} / \mathrm{s}$ and line spacing of $16 \mu \mathrm{m}$ were used.

Data acquisition was performed in time-resolved analysis mode as a single continuous experiment. Each analysis comprised a suite of 39 elements (Figures S4-S6 and Datasets S1 and S2); dwell times for major elements were $0.005 \mathrm{~s}$ (to reduce excessive count rates) and all other masses were $0.008 \mathrm{~s}$, giving a total sweep time of $0.31 \mathrm{~s}$. Standards were analysed in duplicate at the start and end of each mapping run, and included reference glasses NIST 610 and 612 (Jochum et al., 2011; Pearce et al., 1997) and garnet standard

MON-GT (C. Harris \& Vogeli, 2010; Chris Harris et al., 2000). Data reduction was performed using the software Iolite (Hellstrom et al., 2008; Paton et al., 2011; Woodhead et al., 2007), with quantification via the Trace Elements DRS applied using ${ }^{29} \mathrm{Si}$ for internal calibration, applicable to garnet pixels only. Finally, image and data processing was completed using XMapTools 2.3.4 (Lanari et al., 2014; Raimondo et al., 2017) and ImageJ (Abramoff, Magalhães \& Ram, 2004).

\section{REFERENCES}

Harris, C., \& Vogeli, J. (2010). OXYGEN ISOTOPE COMPOSITION OF GARNET IN THE PENINSULA GRANITE, CAPE GRANITE SUITE, SOUTH AFRICA: CONSTRAINTS ON MELTING AND EMPLACEMENT MECHANISMS. South African Journal of Geology, 113(4), 401-412. https://doi.org/10.2113/gssajg.113.4.401

Harris, Chris, Smith, H. S., \& le Roex, A. P. (2000). Oxygen isotope composition of phenocrysts from Tristan da Cunha and Gough Island lavas: Variation with fractional crystallization and evidence for assimilation. Contributions to Mineralogy and Petrology, 138(2), 164-175. https://doi.org/10.1007/s004100050015 
Hellstrom, J., Paton, C., Woodhead, J., \& Hergt, J. (2008). Iolite : Software for spatially resolved LA-(quad and MC) ICPMS analysis. Mineralogical Association of Canada short course series, 40, 343-348.

Jochum, K. P., Weis, U., Stoll, B., Kuzmin, D., Yang, Q., Raczek, I., Jacob, D. E., Stracke, A., Birbaum, K., Frick, D. A., Günther, D., \& Enzweiler, J. (2011). Determination of Reference Values for NIST SRM 610617 Glasses Following ISO Guidelines. Geostandards and Geoanalytical Research, 35(4), 397-429. https: / /doi.org/10.1111/j.1751-908X.2011.00120.x

Lanari, P., Vidal, O., De Andrade, V., Dubacq, B., Lewin, E., Grosch, E. G., \& Schwartz, S. (2014). XMapTools: A MATLAB৫-based program for electron microprobe X-ray image processing and geothermobarometry. Computers \& Geosciences, 62, 227-240. https://doi.org/10.1016/j.cageo.2013.08.010

Paton, C., Hellstrom, J., Paul, B., Woodhead, J., \& Hergt, J. (2011). Iolite : Freeware for the Visualisation and Processing of Mass Spectrometric Data. J. Anal. At. Spectrom. VL - IS -, online. https://doi.org/10.1039/C1JA10172B

Pearce, N. J. G., Perkins, W. T., Westgate, J. A., Gorton, M. P., Jackson, S. E., Neal, C. R., \& Chenery, S. P. (1997). A Compilation of New and Published Major and Trace Element Data for NIST SRM 610 and NIST SRM 612 Glass Reference Materials. Geostandards Newsletter, 21(1), 115-144. https://doi.org/10.1111/j.1751-908X.1997.tb00538.x

Raimondo, T., Payne, J., Wade, B., Lanari, P., Clark, C., \& Hand, M. (2017). Trace element mapping by LA-ICPMS : Assessing geochemical mobility in garnet. Contributions to Mineralogy and Petrology, 172(4), 17. https: / /doi.org/10.1007/s00410-017-1339-z

Woodhead, J. D., Hellstrom, J., Hergt, J. M., Greig, A., \& Maas, R. (2007). Isotopic and Elemental Imaging of Geological Materials by Laser Ablation Inductively Coupled Plasma-Mass Spectrometry. Geostandards and Geoanalytical Research, 31(4), 331-343. https://doi.org/10.1111/j.1751-908X.2007.00104.x 


\section{Appendix S2 : U-Th-Pb monazite and zircon geochronology analytical procedures}

The identification, distribution and characterization of chemical zoning of monazite was performed in-situ, following the approach of Williams, Jercinovic, Goncalves \& Mahan (2006), on a Cameca SX100 ${ }^{\circledR}$ electron microprobe at the Laboratoire Magmas et Volcans in Clermont-Ferrand (France). All monazite grains were identified through full-thin-section X-ray mapping for Ce La, P Ka along with Al Ka, Mg Ka to obtain a mineralogically and texturally map in order to reveal the monazite distribution with respect to the leucosome, quartz saturated and undersaturated domains (Figure 18). Analytical conditions were a $15 \mathrm{keV}$ accelerating voltage with a $200 \mathrm{nA}$ beam current, a defocussed beam at $35 \mu \mathrm{m}$, and a counting time of $9 \mathrm{~ms}$ per pixel with a $35 \mu \mathrm{m}$ pixel setp size. High resolution compositional maps were performed on all the selected grains for Y La, Ca Ka, Th Ma and U MB. Analytical conditions were 15 kV, 200 Na with a rastering focussed beam. Counting time varies from 100 to $150 \mathrm{~ms}$, with a step size ranging from 0.4 to $1 \mu \mathrm{m}$. Intensities of all raw compositional were normalized in counts per second and processed all together so that gray levels (i.e. composition) and zoning features can be compared from grain to grain. Zircon were identified via a conventional optical microscope.

$\mathrm{U}$-Th-Pb geochronology of zircon and monazite was conducted by laser ablation inductively coupled plasma spectrometry (LA-ICPMS) at the Laboratoire Magmas et Volcans, Clermont-Ferrand (France). The analyses involve the ablation of minerals with a Resonetics Resolution $M-50$ powered by an ultra short pulse ATL Atlex Excimer laser system operating at a wavelength of $193 \mathrm{~nm}$ (detailed description in Müller, Shelley, Miller \& Broude (2009). Spot diameters of $20-26 \mu \mathrm{m}$ and $7 \mu \mathrm{m}$ associated to repetition rates of $3 \mathrm{~Hz}$ and $1 \mathrm{~Hz}$ were used for zircon and monazite respectively. The ablated material is carried into helium, and then mixed with nitrogen and argon, before injection into a plasma source of an Agilent 7500 cs ICP-MS equipped with a dual pumping system to enhance the sensitivity.

The alignment of the instrument and mass calibration was performed before every analytical session using the NIST SRM 612 reference glass, by inspecting the signal of $238 \mathrm{U}$ and by minimising the ThO+/Th+ ratio $(<<1 \%)$. The mean sensitivity on ${ }^{238} \mathrm{U}$ at the instrumental conditions reported in Table 1 and using a spot size of $44 \mu \mathrm{m}$ is about $15-20,000 \mathrm{cps} / \mathrm{ppm}$. The analytical method for isotope dating of monazite with laser ablation ICPMS is basically similar to that developed for zircon and monazite and reported in Paquette \& Tiepolo (2007) and Tiepolo, Bottazzi, Palenzona \& Vannucci (2003). The signal of ${ }^{204}(\mathrm{~Pb}+\mathrm{Hg}),{ }^{206} \mathrm{~Pb},{ }^{207} \mathrm{~Pb},{ }^{208} \mathrm{~Pb},{ }^{232} \mathrm{Th}$ and ${ }^{238} \mathrm{U}$ 
masses are acquired. The occurrence of common $\mathrm{Pb}$ in the sample can be monitored by the evolution of the ${ }^{204}(\mathrm{~Pb}+\mathrm{Hg})$ signal intensity, but no common $\mathrm{Pb}$ correction was applied owing to the large isobaric interference from $\mathrm{Hg}$. The ${ }^{235} \mathrm{U}$ signal is calculated from ${ }^{238} \mathrm{U}$ on the basis of the ratio ${ }^{238} \mathrm{U} /{ }^{235} \mathrm{U}=137.88$. Single analyses consisted of 20 seconds of background integration with laser off followed by 1 minute integration with the laser firing and a 20 seconds delay to wash out the previous sample (approximatively 10 seconds for 6 orders of magnitude) and prepare the next analysis.

Data are corrected for $\mathrm{U}-\mathrm{Pb}$ and $\mathrm{Th}-\mathrm{Pb}$ fractionation occurring during laser sampling and for instrumental mass discrimination (mass bias) by standard bracketing with repeated measurements of GJ-1 zircon (Jackson, Pearson, Griffin \& Belousova, 2004) or Moacyr monazite (Gasquet, Bertrand, Paquette, Lehmann \& Ratzov, 2010) standard. Data reduction was carried out with the software package GLITTER® (Macquarie Research Ltd, 2001; Jackson et al. (2004); Van Achterbergh, Ryan, Jackson \& Griffin (2001). For each analysis, the time resolved signal of single isotopes and isotope ratios was monitored and carefully inspected to verify the presence of perturbations related to inclusions, fractures, mixing of different age domains or common $\mathrm{Pb}$. Calculated ratios were exported and Concordia ages and diagrams were generated using Isoplot/Ex v. 2.49 software package by Ludwig (2001). The concentrations in U-Th-Pb were calibrated relative to the certified contents of 91500 zircon standard (Wiedenbeck, Allé, Corfu, Griffin \& Meier, 1995) and Moacyr monazite (Seydoux-Guillaume, Wirth, Deutsch \& Schärer, 2004).

\section{REFERENCES}

Gasquet, D., Bertrand, J.-M., Paquette, J.-L., Lehmann, J., Ratzov, G., Guedes, R. D. A., Tiepolo, M., Boullier, A.-M., Scaillet, S., \& Nomade, S. (2010). Miocene to Messinian deformation and hydrothermal activity in a pre-Alpine basement massif of the French western Alps: New U-Th-Pb and argon ages from the Lauzière massif. Bulletin de La Societe Geologique de France, 181(3), 227-241. https://doi.org/10.2113/gssgfbull.181.3.227

Jackson, S. E., Pearson, N. J., Griffin, W. L., \& Belousova, E. A. (2004). The application of laser ablationinductively coupled plasma-mass spectrometry to in situ U-Pb zircon geochronology. Chemical Geology, 211(1), 47-69. https://doi.org/10.1016/j.chemgeo.2004.06.017 
Ludwig, K. (2001). Users manual for Isoplot/Ex Version 2.49: A geochronological toolkit for Microsoft Excel. Berkeley Geochronology Center Spec. Publ., 1a, 55.

Müller, W., Shelley, M., Miller, P., \& Broude, S. (2009). Initial performance metrics of a new custom-designed ArF excimer LA-ICPMS system coupled to a two-volume laser-ablation cell. Journal of Analytical Atomic Spectrometry, 24(2), 209-214. https://doi.org/10.1039/B805995K

Paquette, J. L., \& Tiepolo, M. (2007). High resolution (5 $\mu \mathrm{m}) \mathrm{U}$-Th-Pb isotope dating of monazite with excimer laser ablation (ELA)-ICPMS. Chemical Geology, 240(3), 222-237. https://doi.org/10.1016/j.chemgeo.2007.02.014

Seydoux-Guillaume, A.-M., Wirth, R., Deutsch, A., \& Schärer, U. (2004). Microstructure of 24-1928 Ma concordant monazites; implications for geochronology and nuclear waste deposits. Geochimica et Cosmochimica Acta, 68(11), 2517-2527. https://doi.org/10.1016/j.gca.2003.10.042

Tiepolo, M., Bottazzi, P., Palenzona, M., \& Vannucci, R. (2003). A laser probe coupled with ICP - Doublefocusing sector-field mass spectrometer for in situ analysis of geological samples and $\mathrm{U}-\mathrm{Pb}$ dating of zircon. The Canadian Mineralogist, 41, 259-272. https://doi.org/10.2113/gscanmin.41.2.259

Van Achterbergh, E., Ryan, C. G., Jackson, S. E., \& Griffin, W. L. (2001). Data reduction software for LA-ICPMS. In Laser ablation-ICPMS in the earth science (Sylvester P., Vol. 29, p. 239-243). Mineralogical Association of Canada.

Wiedenbeck, M., Allé, P., Corfu, F., Griffin, W. L., Meier, M., Oberli, F., Quadt, A. V., Roddick, J. C., \& Spiegel, W. (1995). Three Natural Zircon Standards for U-Th-Pb, Lu-Hf, Trace Element and Ree Analyses. Geostandards Newsletter, 19(1), 1-23. https://doi.org/10.1111/j.1751-908X.1995.tb00147.x Williams, M. L., Jercinovic, M. J., Goncalves, P., \& Mahan, K. (2006). Format and philosophy for collecting, compiling, and reporting microprobe monazite ages. Chemical Geology, 225(1-2), 1-15. 